\title{
Optimaal gebruik van diagnostische tests: een economisch-besliskundige analyse
}

Citation for published version (APA):

Ament, A. J. H. A. (1989). Optimaal gebruik van diagnostische tests: een economisch-besliskundige analyse. [Doctoral Thesis, Maastricht University]. Rijksuniversiteit Limburg. https://doi.org/10.26481/dis.19890428aa

Document status and date:

Published: 01/01/1989

DOI:

10.26481/dis.19890428aa

Document Version:

Publisher's PDF, also known as Version of record

\section{Please check the document version of this publication:}

- A submitted manuscript is the version of the article upon submission and before peer-review. There can be important differences between the submitted version and the official published version of record. People interested in the research are advised to contact the author for the final version of the publication, or visit the DOI to the publisher's website.

- The final author version and the galley proof are versions of the publication after peer review.

- The final published version features the final layout of the paper including the volume, issue and page numbers.

Link to publication

\footnotetext{
General rights rights.

- You may freely distribute the URL identifying the publication in the public portal. please follow below link for the End User Agreement:

www.umlib.nl/taverne-license

Take down policy

If you believe that this document breaches copyright please contact us at:

repository@maastrichtuniversity.nl

providing details and we will investigate your claim.
}

Copyright and moral rights for the publications made accessible in the public portal are retained by the authors and/or other copyright owners and it is a condition of accessing publications that users recognise and abide by the legal requirements associated with these

- Users may download and print one copy of any publication from the public portal for the purpose of private study or research.

- You may not further distribute the material or use it for any profit-making activity or commercial gain

If the publication is distributed under the terms of Article $25 \mathrm{fa}$ of the Dutch Copyright Act, indicated by the "Taverne" license above, 


\section{OPTIMAAL GEBRUIK VAN DIAGNOSTISCHE TESTS:}

EEN ECONOMISCH-BESLISKUNDIGE ANALYSE 


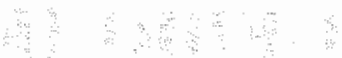

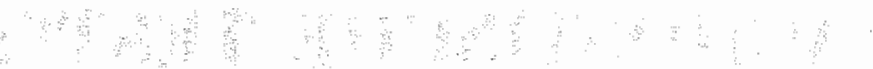




\title{
OPTIMAAL GEBRUIK VAN DLAGNOSTISCHE TESTS: EEN ECONOMISCH-BESLISKUNDIGE ANALYSE
}

\author{
PROEFSCHRIFT \\ ter verkrijging wan de graad wan doctor aan de \\ Rijksuniversiteit Limburg te Maastricht, op gezag \\ van de Rector Magnificus, Prof.dr. F. I.M. Bonke, \\ volgens het besluit van het College van Dekanen, \\ in het openbaar te verdedigen op \\ vrijdag, 28 april 1989 om 14.00 wur \\ door \\ Andreas Jacobus Hubertus Antonius Ament \\ geboren te Nederweert
}


Promotor:

Tweede promotor:

Beoordelingscommissie:
Prof.Dr. F.F.H. Rutten

Prof.Dr.Ir. A Hasman

Prof.Dr. F. Sturmans (voorzitter)

Prof.Dr. L.M.J. Groot †

Prof.Dr. J.D.F. Habbema

Prof.Dr. J.A Knottnerus

Dr. J.F. Leyten 


\section{VOORWOORD}

Het schrijven van een dissertatie is een activiteit die hoofdzakelijk te beschouwen is als een individuele inspanning. Deze activiteit is echter niet te voltooien zonder dat vele personen in woord en/of daad hierbij hun steun verlenen.

Prof.dr. F. Rutten en Prof.dr. A Hasman hebben, als promotoren, mij de weg gewezen en mij behoed voor talloze voetangels en klemmen op het pad van de wetenschap. Jullie niet aflatende bereidheid om het steeds maar aangroeiende manuscript te voorzien van kanttekeningen heb ik ervaren als een grote stimulans. Hartelijk dank voor jullie steun!

Speciale dank ben ik verder verschuldigd aan Prof.dr. L. Groot. Lou ken ik al vanaf het moment dat ik kwam werken aan de Rijksuniversiteit Limburg, toen deze nog "in oprichting" was. Ik heb hem leren kenmen en waarderen als een grote deskundige op het terrein van de gezondheidseconomie en als een integer persoon met een bijzonder gevoel voor humor. Hij was het ook die mij in aanraking bracht met het ziekenhuislaboratorium als een interessant studie-object. Dat ik het onderwerp uiteindelijk toch van een geheel andere kant zou benaderen konden wij beiden op dat moment nog niet bevroeden. Ik voelde me zeer vereerd dat hij bereid was als lid van de beoordelingscommissie op te treden. Hij heeft nog wel kennis kunnen nemen van de inhoud van het proefschrift, maar er restte hem niet voldoende tijd om ook bij mijn promotie aanwezig te zijn. Hij had er zo graag bij willen zijn.

Graag zeg ik ook dank aan de overige leden van de beoordelingscommissie: Prof.dr. F. Sturmans, Prof.dr. J. Knottnerus, Prof.dr. J. Habbema en Dr. J. Leyten. Van jullie suggesties heb ik dankbaar gebruik gemaakt bij het opstellen van de definitieve tekst.

Ook binnen mijn directe werkomgeving zijn er talloze personen die mij hebben geholpen om het onderzoek te voltooien en vervolgens hebben meegeholpen met de voltooiing van dit boek.

In de eerste plaats zijn dit Ellen Breevoort en Hans Trouw. Jullie positie als paranimf is meer dan een symbolische. Ellen heeft zich onder andere bezig gehouden met de uitvoering van talloze berekeningen en het ontwerp van de vele grafische voorstellingen. Hans, de inhoudelijke discussies die ik met jou mocht voeren bleken steeds opnieuw weer richtinggevend te zijn voor mij. Ik denk er met plezier an terug. Voor jullie beiden geldt: de typefauten die jullie in de laatste versie hebben laten staan zal ik jullie niet aanrekenen.

Naast Ellen en Hans ben ik veel dank verschuldigd aan Jan van Emmerik, de steun en toeverlaat van de vakgroep Economie van de Gezondheidszorg op het terrein van de automatische informatieverwerking.

Ik moet bekennen dat ik vaak medelijden heb gehad als je zat te zwoegen met de zoveelste versie van het computerprogramma of de zoveelste versie van het manuscript. Ik beschouw je als mijn derde paranimf.

Niet onvermeld mag blijven Maria Kalivas. Ik heb veell bewondering voor het feit dat jij er steeds weer in slaagde om mijn handschrift te decoderen. Ook Brigitte Kerbusch hielp bij tijd en wijle mee om het manuscript op tijd af te krijgen.

Naast boven, met name genoemde, personen, zijn er nog velen die hun steentje hebben bijgedragen. Vooral de collega's van de vakgroep Economie van de Gezondheidszorg. 
Ook wil ik Alex Koning bedanken voor zijn bijdrage aan hoofdstuk 6 en Guus van Rooy voor het maken van het ontwerp voor de omslag.

Tenslotte wil ik het thuisfront in mijn dankbetuiging betrekken. Op dit proefschrift is namelijk de wet van Hofstadter van toepassing. Deze wet, die te vinden is in het boek van Hofstadter, getiteld "Gödel, Escher, Bach: een eeuwige gouden band" luidt: "Het duurt altijd langer dan je denkt, ook al houd je rekening met de Wet van Hofstadter". Een en ander heeft ertoe geleid dat er toch heel wat tijd is gaan zitten in het schrijven van dit boek. Gerry, maar ook Boris, Owen en Bregje, ik ben jullie dankbaar voor de warmte die ik van jullie mocht ontvangen. 
1. DE VRAAG NAAR TESTS $\ldots \ldots \ldots \ldots \ldots \ldots \ldots \ldots \ldots \ldots$

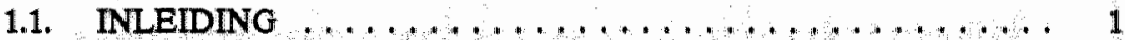

1.2. FUNCTIES VAN TESTS $\ldots \ldots \ldots \ldots \ldots \ldots \ldots \ldots \ldots, 2$

1.3. HET BESLISKUNDIG PROCES M.B.T. HET GEBRUIK

VAN TESTS ........................ 4

1.4. EVALUATIE VAN TESTS $\ldots \ldots \ldots \ldots \ldots \ldots \ldots \ldots \ldots . \ldots$

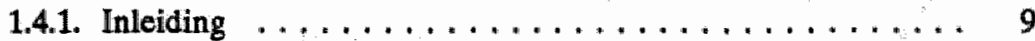

1.4.2. Het syntactisch niveau $\ldots \ldots \ldots \ldots \ldots \ldots \ldots \ldots \ldots$

1.4.3. Mate van informativiteit $\ldots \ldots \ldots \ldots \ldots \ldots \ldots \ldots 12$

1.4.4. Het effectiviteitsniveau $\ldots \ldots \ldots \ldots \ldots \ldots \ldots \ldots . \ldots 13$

1.5. PROBLEEMSTELLING $\ldots \ldots \ldots \ldots \ldots \ldots \ldots \ldots \ldots \ldots, 14$

1.6. OPZET STUDIE $\ldots \ldots \ldots \ldots \ldots \ldots \ldots \ldots \ldots \ldots \ldots \ldots$

2. HET LABORATORIUM $\ldots \ldots \ldots \ldots \ldots \ldots \ldots \ldots \ldots \ldots \ldots$

2.1. INLEIDING $\ldots \ldots \ldots \ldots \ldots \ldots \ldots \ldots \ldots \ldots \ldots \ldots \ldots$

2.2. GROEI LABORATORIUMPRODUCTIE .......... 18

2.3. OORZAKEN STIJGING LABORATORIUMPRODUCTIE . . . 20

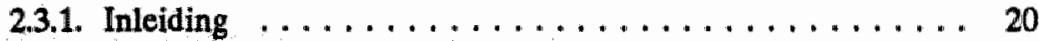

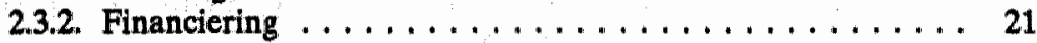

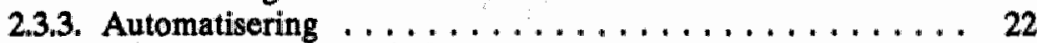

2.4. BEHEERSINGSSTRATEGIEEN $\ldots \ldots \ldots \ldots \ldots \ldots \ldots \ldots 25$

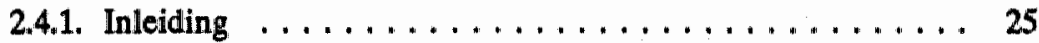

2.4.2. Het laboratorium op commerciele leest . . . . . . . 26

2.4.3. Bedrijfseconomische maatregelen . . . . . . . . . 27

2.4.4. Niet-financiele drempels $\ldots \ldots \ldots \ldots \ldots \ldots \ldots \ldots \ldots 28$

2.5. CONCLUSIE . . . . . . . . . . . . . . . . . . . . . 29

3. DE ROL VAN DE ARTS BIJ HET AANVRAGEN VAN TESTS $\ldots \ldots, 31$

3.1. INLEIDING $\ldots \ldots \ldots \ldots \ldots \ldots \ldots \ldots \ldots \ldots \ldots \ldots \ldots, 31$

3.2. VARIATIE IN AANVRAAGGEDRAG $\ldots \ldots \ldots \ldots \ldots \ldots, 32$

3.3. PERSOONSGEBONDEN YARIATIE $\ldots \ldots \ldots \ldots \ldots \ldots \ldots, 34$

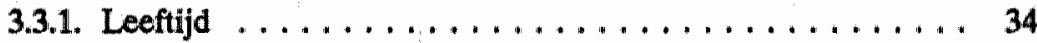

3.3.2. Risicogedrag $\ldots \ldots \ldots \ldots \ldots \ldots \ldots \ldots \ldots \ldots \ldots, 34$

3.3.3. Kostenbewustzijn . . . . . . . . . . . . . . 35

3.4. INSTITUUTSGEBONDEN FACTOREN $\ldots \ldots \ldots \ldots \ldots \ldots \ldots, 36$

3.5. OPTIMALISATIE VAN AANVRAAGGEDRAG $\ldots \ldots \ldots \ldots 38$

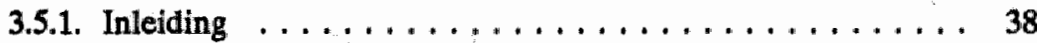

3.5.2. Medische opleiding $\ldots \ldots \ldots \ldots \ldots \ldots \ldots \ldots \ldots$

3.5.3. Feedback ....................... 41

3.5.4. Financiěle prikkels en limitering $\ldots \ldots \ldots \ldots \ldots \ldots 43$

3.6. SAMENVATTING EN CONCLUSIES $\ldots \ldots \ldots \ldots \ldots \ldots \ldots 45$

4. DLAGNOSTISCHE EFFECTIVITEIT $\ldots \ldots \ldots \ldots \ldots \ldots \ldots \ldots \ldots$

4.1. INLEIDING $\ldots \ldots \ldots \ldots \ldots \ldots \ldots \ldots \ldots \ldots \ldots \ldots, 47$

4.2. DICHOTOME TEST EN ZIEKTE . . . . . . . . . . . . . 47

4.2.1. Predictieve waarde $\ldots \ldots \ldots \ldots \ldots \ldots \ldots \ldots \ldots, \ldots$

4.2.2. Likelihood ratio $\ldots \ldots \ldots \ldots \ldots \ldots \ldots \ldots \ldots \ldots$

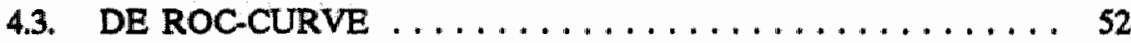


4.4. VERWACHTINGSWAARDE ONZEKERHEIDSREDUCTIE _. 56

4.5. INFORMATIETHEORIE . . . . . . . . . . . . . . . . . 59

4.6. VERGELIJKING CONNELL EN KOEPSELL MET

SHIANNON $\ldots \ldots \ldots \ldots \ldots \ldots \ldots \ldots \ldots \ldots \ldots \ldots \ldots$

5. KOSTEN-EFFECTIVITEITSANALYSE VAN TESTSTRATEGIEEN:

een procesbenadering $\ldots \ldots \ldots \ldots \ldots \ldots \ldots \ldots \ldots \ldots \ldots \ldots \ldots \ldots 73$

$5.1, \quad$ INLEIDING $\ldots \ldots \ldots \ldots \ldots \ldots \ldots \ldots \ldots \ldots \ldots \ldots, 73$

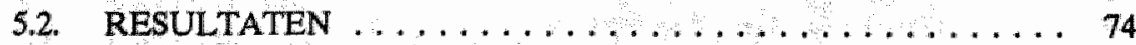

5.3. KOSTEN PER OPBRENGST $\ldots \ldots \ldots \ldots \ldots \ldots \ldots \ldots . \ldots 75$

5.4. INVLOED KOSTENVERHOUDING $\ldots \ldots \ldots \ldots \ldots \ldots \ldots 78$

5.5. INVLOED VAN DE A PRIORI KANS EN DE

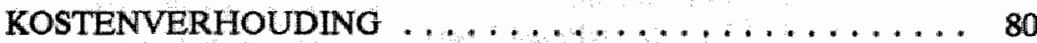

5.6. SAMENVATTING EN CONCLUSIES $\ldots \ldots \ldots \ldots \ldots \ldots . \ldots 8$

6. HET OPTIMALE AFKAPPUNT VAN EEN TEST, EEN ECONOMI-

SCHE BENADERING $\ldots \ldots \ldots \ldots \ldots \ldots \ldots \ldots \ldots \ldots \ldots \ldots$

6.1. INLEIDING $\ldots \ldots \ldots \ldots \ldots \ldots \ldots \ldots \ldots \ldots \ldots . \ldots . \ldots . \ldots . \ldots$

6.2. EVALUATIE MODEL DIAGNOSTISCHE TEST $\ldots \ldots \ldots, 87$

6.2.1. Kosten . . . . . . . . . . . . . . . . . . . . . . . 87

6.2.2. Opbrengsten .................. 88

6.3. VERGELIJKING EVALUATIE MONITORING TEST MET

DIAGNOSTISCHE TEST $\ldots \ldots \ldots \ldots \ldots \ldots \ldots \ldots \ldots \ldots . \ldots 8$

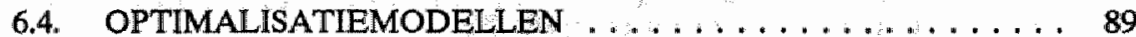

6.4 .1$. Inleiding $\ldots \ldots \ldots \ldots \ldots \ldots \ldots \ldots \ldots \ldots$

6.4.2. Het model ......................... . 90

6.4.3. Winstmaximalisatie of kosten/effectiviteit .......... 94

6.4.4. Optimaal afkappunt $\ldots \ldots \ldots \ldots \ldots \ldots \ldots \ldots \ldots . \ldots 98$

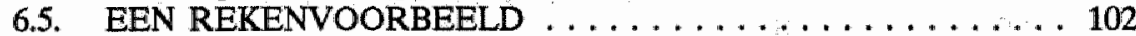

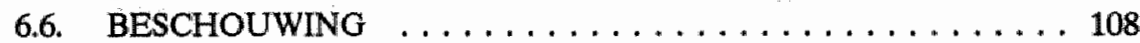

7. KOSTEN EN OPBRENGSTEN VAN TESTS $\ldots \ldots \ldots \ldots \ldots \ldots \ldots \ldots$

7.1. INLEIDING $\ldots \ldots \ldots \ldots \ldots \ldots \ldots \ldots \ldots \ldots \ldots \ldots \ldots \ldots$

7.2. WAARDE VAN INFORMATIE $\ldots \ldots \ldots \ldots \ldots \ldots \ldots, 112$

7.3. VERGELIJKING ENKELE METHODEN $\ldots \ldots \ldots \ldots \ldots, 123$

7.4. TESTS IN DE GEZONDHEIDSZORG $\ldots \ldots \ldots \ldots \ldots \ldots 127$

7.5. KOSTEN EN OPBRENGSTEN $\ldots \ldots \ldots \ldots \ldots \ldots \ldots \ldots \ldots 131$

8. OPTIMALE STRATEGIE BLJ TWEE TESTS $\ldots \ldots \ldots \ldots \ldots \ldots 135$

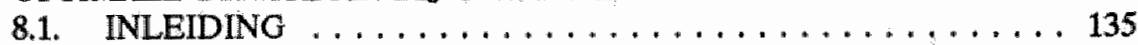

8.2. COMBINATIE VAN TWEE TESTS .............. 136

8.3. ECONOMISCHE EVALUATIE VAN TESTCOMBINATIES ... 139

8.3.1. Inleiding . . . . . . . . . . . . . . . . . . 139

8.3.2. Conjunctief of disjunctief $\ldots \ldots \ldots \ldots \ldots \ldots \ldots 140$

8.3.3. Incrementele analyse $\ldots \ldots \ldots \ldots \ldots \ldots \ldots \ldots \ldots 143$

8.3.4. Combinatie van (on)afhankelijke tests . . . . . . . . . . 144

8.4. TOEPASSING VAN HET PROGRAMMA OP EEN

8.5. RESULTATEN BASISMODEL $\ldots \ldots \ldots \ldots \ldots \ldots \ldots \ldots \ldots . \ldots \ldots$

8.5.1. Opbrengsten-kosten . . . . . . . . . . . . . . . . . . . 149

8.5.2. Resultaten met betrekking tot de opsporing van

borstkankermetastasen 


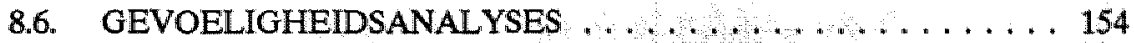

8.6.1. Gevoeligheidsanalyse van de waarde van een QALY . . . 154

8.6.2. Gevoeligheidsanalyse met betrekking tot kosten van

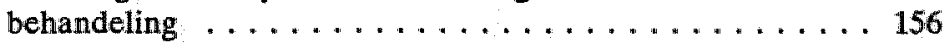

8.6.3. Gevoeligheidsanalyse winst behandelen (U1) . . . . . . 159

8.6.4. Gevoeligheidsanalyse winst ten onrechte behandelen (U2), criterium $\mathrm{O}-\mathrm{K} \ldots \ldots \ldots \ldots \ldots \ldots \ldots \ldots$

8.6.5. Gevoeligheidsanalyse kosten US, criterium O-K ..... 160

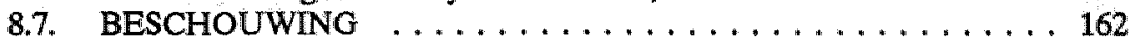

9. MEDISCHE BESLISKUNDE EN BUDGETTERING: CLINICAL

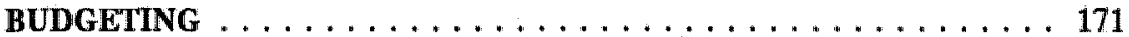

9.1. INLEIDING $\ldots \ldots \ldots \ldots \ldots \ldots \ldots \ldots \ldots \ldots \ldots \ldots \ldots \ldots$

9.2. MEDISCHE BESLISKUNDE $\ldots \ldots \ldots \ldots \ldots \ldots \ldots \ldots 171$

9.2.1. Inleiding $\ldots \ldots \ldots \ldots \ldots \ldots \ldots \ldots \ldots \ldots \ldots 171$

9.2.2. Medische besliskunde . . . . . . . . . . . . 172

9.2.3. Besliskunde in de medische praktijk . . . . . . . 178

9.3. BUDGETTERING EN MEDISCHE BESLISKUNDE . . . . . 181

9.3.1. Inleiding $\ldots \ldots \ldots \ldots \ldots \ldots \ldots \ldots \ldots \ldots \ldots \ldots$

9.3.2. Budgettering en de professie . . . . . . . . . . 181

9.3.3. Budgettering en kosten-effectief gedrag .......... 183

9.4. IMPLICATIES VAN HET ONTWIKKELDE MODEL VOOR

DE PRAKTIJK $\ldots \ldots \ldots \ldots \ldots \ldots \ldots \ldots \ldots$

SAMENVATTING . . . . . . . . . . . . . . . . . . . . . . . . 191

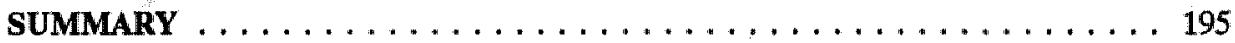

LITERATUURLIJST . . . . . . . . . . . . . . . . . . . . . . . . 199

LIJST VAN FIGUREN $\ldots \ldots \ldots \ldots \ldots \ldots \ldots \ldots \ldots \ldots \ldots \ldots \ldots \ldots$

LIJST VAN TABELLEN $\ldots \ldots \ldots \ldots \ldots \ldots \ldots \ldots \ldots \ldots \ldots \ldots \ldots$

CURRICULUM VITAE $\ldots \ldots \ldots \ldots \ldots \ldots \ldots \ldots \ldots \ldots \ldots \ldots \ldots$ 
In Memoriam Lou Groot

Aan Gerry

Boris, Owen en Bregje 


\subsection{INLEIDING}

Technologische ontwikkelingen zorgen ervoor dat de arts in staat wordt gesteld steeds meer nieuwe diagnostische en preventieve middelen te gebruiken. De snelheid van deze ontwikkeling en de complexiteit en de consequenties ervan voor de samenleving, leiden ertoe dat het idee heeft postgevat dat meer informatie nodig is ten behoeve van de besluitvorming betreffende het mogelijk gebruik van technologie in de gezondheidszorg. In de zeventiger jaren uit zich dit vooral in een roep naar beheersing van thet gebruik wan de dure, recent ontwikkelde geavanceerde technologieèn. Steeds meer is men gaan beseffen dat beheersing van het gebruik wan dergelijke technologieen weliswaar dringend gewenst is, maar dat hiermee niet de integrale invloed van de technologische ontwikkeling binnen de gezondheidszorg wordt bestreken (Moloney \& Rogers, 1979). De totale kosten van de zogenaamde "little-ticket" technologie, de technologie met betrekking tot het dagelijks min of meer routinematig medisch handelen (verder te noemen "lichte" technologie), overschrijden de totale kosten van de toepassing van de meer geavanceerde technologieën vele malen (Groot \& Visinescu, 1980). Ondanks dit feit wordt er tot nog toe weinig energie gestoken in de evaluatie van de doelmatigheid en doeltreffendheid van deze technologieën.

Dat de evaluatie van lichte technologieèn tot nu toe weinig aandacht kreeg, is mede in de hand gewerkt door de wijze van financiering.

Voór de invoering van de budgettering was in algemene ziekenhuizen geen incentive aanwezig om het gebruik van lichte technologie te beperken. Integendeel, gebruik ervan werd financieel beloond. Sinds de invoering van de budgettering is het totaal aan te wenden bedrag binnen het ziekenhuis gelimiteerd en naarmate de schaarste in sterkere mate gevoeld wordt, zal het economische aspect bij het nemen van diagnostische en therapeutische beslissingen meer op de voorgrond treden.

In dit boek wordt de aandacht met name gericht op het gebruik van tests, welke een niet onaanzienlijk deel van de totale lichte technologie vertegenwoordigen. Een test is een middel om informatie te verkrijgen over het al of niet aanwezig zijn van ziekte bij een persoon.

Het begrip test slaat in het boek zowel op het laboratoriumonderzoek als ook op het radiologisch onderzoek. Ook anamnese en lichamelijk onderzoek kunnen informatie over het al of niet aanwezig zijn van ziekten opleveren, doch worden in dit kader niet expliciet besproken. De informatie uit het lichamelijk onderzoek en de anamnese wordt indirect meegenomen in de besluitvorming doordat verondersteld wordt dat deze informatie verwerkt wordt in de a priori kans op de ziekte, dat wil zeggen de kans op de ziekte vóordat de test wordt aangevraagd.

Tests worden in de gezondheidszorg zowel door specialisten als door huisartsen aangevraagd. In principe kunnen de ewaluatie-technieken, welke hieronder besproken worden, door beide groepen beroepsbeoefenaren worden aangewend. Echter, in dit boek is het ziekenhuis als referentiekader gebruikt. Alle voorbeelden zijn dan ook ontleend aan de praktijk van het specialistisch handelen. 
Dat het testgebruik is gekozen tot object van studie heeft een aantal redenen. In de eerste plaats heeff er een enorme groei plaats gevonden in het aantal laboratoriumverrichtingen. In de zeventiger jaren kwamen groeipercentages van $10 \%$ of meer per jaar veelvuldig voor. In de tachtiger jaren nam de groei af, waarschijnlijk onder invloed van veranderingen in het financieringssysteem (zie hoofdstuk 2). Daarmee is de economische relevantie van het onderwerp aangeduid. In de tweede plaats is het zo, dat zowel de ontwikkeling van medische kennis, als ook de technologische ontwikkelingen zich sneller lijken te woltrekken op diagnostisch dan op therapeutisch gebied. Dit impliceert dat de grenzen tussen datgene wat theoretisch haalbaar is en datgene wat in de praktijk gedaan wordt, steeds verder uit elkaar groeien, waardoor het keuzeprobleem ten aanzien van de aanwending van diagnostische middelen steeds gecompliceerder wordt. Met dit laatste is de besliskundige relevantie van het onderhavige studie-object aangegeven.

\subsection{FUNCTIES VAN TESTS}

Tests hebben tot doel de arts informatie te verschaffen over de gezondheidstoestand van personen. Indien personen klachtenvrij zijn, kan men er via screening achter komen of er wellicht toch een bepaalde ziekte aanwezig is. Wanneer een persoon reeds ziekteverschijnselen vertoont, kunnen tests van nut zijn om vast te stellen welke specifieke ziekte het hier betreft of om vast te stellen dat de patiënt de ziekte nog steeds heeft, Indien tests op deze wijze worden ingedeeld naar toepassingsgebied is er sprake van een driedeling in: screening, diagnostiek en monitoring (Murphey e.a., 1978; Griner e.a., 1981). Naast deze primaire toepassingsgebieden kunnen er nog andere functies van tests onderscheiden worden, welke voor ons doel evenwel van minder belang zijn. Zo worden tests ook wel gebruikt om de ernst van de ziekte te bepalen of de geschiktheid van de therapie (Young, 1982). Bij monitoring kan verder onderscheid gemaakt worden in monitoring van het beloop van het ziekteproces zelf en monitoring van de neveneffecten. Tests kunnen tenslotte aangevraagd worden om bijvoorbeeld de nieuwsgierigheid van de arts te bevredigen of om de patiênt gerust te stellen. Verder zijn er aanwijzigingen dat tests cok een functie kunnen vervullen in het communicatieproces tussen verwijzer en diagnosticus (Holmes e.a., 1982).

\section{Tests ten behoeve van screening}

Screening betreft de uitwoering van tests bij ogenschijnlijk gezonde individuen met als doel groepen met een hoge en een lage waarschijnlijkheid op de ziekte te onderscheiden (Sackett; 1975). Dit kan geschieden met het oog op verschillende doeleinden. In de eerste plaats kan onderscheid gemaakt worden naar de context waarbinnen de screening plaatsvindt. Wordt de test uitgevoerd om de gezondheid van personen te beïnvloeden of wordt de test gebruikt voor doeleinden buiten de gezondheidszorgsector? Zo kan de uitslag van de test bijvoorbeeld gebruikt worden door een verzekeringsmaatschappij om de aanvraag voor een levensverzekering al of niet te accepteren. Binnen de gezondheidszorg kan onderscheid gemaakt worden tussen besmettelijke en niet besmettelijke ziekten. Opsporen en behandelen van besmettelijke ziekten heeft tot doel de gezondheid van individuen te verbeteren en tevens in te grijpen in de transmissie van de ziekte in de bevolking, waardoor de ingreep een collectief karakter krijgt. Als voorbeelden van screening op besmettelijke ziekten kunnen dienen: bevolkingsonderzoek op TBC (dat overigens enkele jaren geleden in Nederland 
is afgeschaft) en screening op AIDS (waaraan in Nederland geen uitvoering wordt gegeven omdat een effectieve behandeling vooralsnog ontbreekt en de nadelen van ongerichte screening groter geacht worden dan de voordelen). Bevestiging van het feit dat iemand gezond is kan in dit verband als opbrengst van de test gezien worden. Is de kans op de ziekte laag, dan is deze opbrengst zeer gering. Indien de kans echter groot is en/of de gevolgen van de ziekte zeer belastend of bedreigend zijn (denk bijv: aan AIDS) dan kan deze opbrengst aanzienlijk zijn (zie verder hoofdstuk 6).

Screeningsprogramma's, die gezondheidswerbetering bij individuen beogen, kunnen uitgevoerd worden bij ogenschijnlijk gezonde personen (ongerichte screening), maar ook in groepen met verhoogde risico's, zoals bijvoorbeeld de populatie die zich aandient in ziekenhuizen. In dit laatste geval kan er opnamescreening plaatsvinden, die informatie kan verschaffen over het primaire indicatiegebied, maar ook over andlere asymptomatische ziekten. Screening in deze laatste betekenis wordt vaak routinematig onderzoek of case-finding genoemd. Het verschil tussen case-finding en screening is dat case-finding in principe uitgaat van het gezondheidszorgsysteem en dat het initiatief tot deelname aan screening uiteindelijk mér bij het individu ligt (Sackett, 1975). Casefinding kan een efficiënte manier zijn van testgebruik (Nolan e.a., 1985), maar het is zeer de vraag of dit in zijn algemeenheid geldt (Prims e.a., 1985).

\section{Tests ten behoeve van diagnostiek}

Op het diagnostisch proces wordt in de navolgende paragraaf dieper ingegaan. Vooruitlopend op deze paragraaf kunnen diagnostische tests omschreven worden als tests die informatie verschaffen over de aan- of afwezigheid van ziekten bij personen. Daarbij kan onderscheid gemaakt worden tussen tests die primair bedoeld zijn om mogelijke ziekten uit te sluiten (ruling-out) en tests, die bepaalde ziekten aannemelijk(er) maken (ruling-in) (Griner e.a., 1981).

Naast deze ruling-in en ruling-out tests wordt ook nog een categorie "bevestigende" tests onderscheiden (Bennington, 1981). Deze tests worden in de laatste fase van het diagnostisch proces gebruikt teneinde de zekerheid van de diagnose te verhogen.

Alle soorten tests leveren informatie op, die beschouwd kan worden als aanvullend op de informatie verkregen uit anamnese en lichamelijk onderzoek. De rol van tests in het diagnostisch proces wordt vaak overschat (Young, 1984). Daarbij komt dat in de praktijk zelfs met de meest optimale laboratorium informatie in 25 tot $30 \%$ van de gevallen de diagnose wordt gemist. (Altshuler, 1981).

\section{Tests ten behoeve van monitoring}

Monitoring tests (ook wel management tests genoemd) worden in principe aangevraagd om informatie in te winnen met betrekking tot de voortgang van de behandeling. Binnen deze monitoring tests zijn ook weer diverse categorieèn te onderscheiden (Griner e.a., 1981). Zo zijn er tests, die primaire gegevens verschaffen over het verloop van de ziekte c.q. het genezingsproces; andere tests zijn specifiek gericht op de monitoring van neveneffecten. Soms bewatten tests woornamelijk informatie over de prognose van de ziekte (Murphey \& Henry, 1978), dan weer kunnen tests gebruikt worden om de dosering van een medicamenteuze therapie te bepalen.

Bij de evaluatie van tests dient rekening gehouden te worden met het doel waarvoor de test is aangevraagd. Derhalve is het nuttig om over een hierop gerichte classificatie 
van tests te beschikken. Het is echter opmerkelijk hoe weinig bekend is over de reden van aanvragen van tests. Op grond van enkele buitenlandse onderzoeken en eén Nederlands onderzoek kan een globaal beeld geconstrueerd worden over het relatieve aandeel wan de hierboven onderscheiden testcategorieën in het totale testgebruik.

$\mathrm{Er}$ is relatief weinig statistisch materiaal bekend over de relatieve frequentie van testgebruik met betrekking tot de hierboven onderscheiden functies van tests. Burke (1981) schat dat het procentuele aandeel van tests in de respectievelijke categories̊n screening, diagnostiek en monitoring ongeveer even groot is, hetgeen empirisch ook bevestigd werd door Wertman e.a. (1980).

Leyten (1985) gaat er vanuit dat ongeveer de helft van alle laboratoriumverrichtingen betrekking heeft op een diagnostisch proces. Hiervan wordt de helft aangevraagd in een fase dat er nog geen sprake is van een gericht zoekproces (vooronderzoek) en de andere helft heeft betrekking op het uitsluiten c.q. bevestigen van specifieke hypothesen, waarbij uitsluiten en bevestigen ongeveer even frequent plaatsvinden. Murphy \& Henry (1978) rapporteren voor het aandeel van monitoring tests $60 \%$ en ook Griner e.a. (1979) en Daniels \& Schroeder (1977) gaan ervan uit dat in de Amerikaanse omgeving het merendeel van de tests aangevraagd wordt ten behoeve van de therapie en dus een minderheid voor diagnostiek.

\subsection{HET BESLISKUNDIG PROCES M.B.T. HET GEBRUIK VAN TESTS}

Voor de evaluatie van het gebruik van tests is het nodig te beschikken over een geformaliseerd model met betrekking tot de inzet van tests ten behoeve van het medisch handelen. In de voorgaande paragraaf is reeds duidelijk geworden dat tests gebruikt kunnen worden voor verschillende doeleinden. Uiteindelijk is het primaire doel van tests het leveren van gegevens over het al of niet aanwezig zijn van ziekten. De arts verzamelt deze gegevens en verwerkt ze tot de uiteindelijke diagnosestelling. Het totaal van activiteiten met betrekking tot het verzamelen en interpreteren van gegevens over ziektetoestanden wordt in dit boek aangeduid met het diagnostisch proces. Wellicht ten overvloede dient te worden opgemerkt dat de arts meer mogelijkheden heeft om informatie te verwerven dan alleen op grond van testuitslagen mogelijk is. Veel informatie is afkomstig uit anamnese en lichamelijk onderzoek.

$\mathrm{Er}$ is betrekkelijk weinig bekend over de wijze waarop artsen tot een diagnose geraken (Politser, 1982). Dit wordt mede in de hand gewerkt door het feit dat de wijze van diagnostiseren blijkt samen te hangen met o.a. de technologische ontwikkelingen in de gezondheidszorg. Shorter (1985) malakt in dit opzicht onderscheid in een drietal perioden. In de periode tot \pm 1870 is de "traditionele arts" werkzaam; die diagnoses stelt louter op basis van subjectieve klachten. Lichamelijk onderzoek stelt nog weinig voor. De diagnose is dan overigens niet veel meer dan een nadere opsomming van klachten en in ieder geval weinig specifiek. In de volgende periode tot \pm 1950 is de "wetenschappelijke geschoolde" arts werkzaam, die langzamerhand de beschikking krijgt over instrumenten, zoals stethoscoop en röntgenfoto's; waarmee daadwerkelijk kan worden gediagnostiseerd. Ook de therapeutische middelen worden in deze periode verfijnder, al bestreden ze in hoofdzaak de symptomen. De "postmoderne" arts, werkzaam vanaf \pm 1950 , is veel meer ziekte-georiënteerd. Hij wordt door Shorter een "meedogenloze diagnosticus" genoemd, iemand die niet rust zolang de definitieve 
diagnose niet gesteld is. Missen van een diagnose is des te erger omdat nu vaak wel effectieve therapieen beschikbaar zijn.

Deze beschrijving maakt duidelijk dat met het toenemen van diagnostische en therapeutische mogelijkheden en de daarmee gepaard gaande kostenontwikkeling, ook een hernieuwde belangstelling is ontstaan voor de wijze waarop de moderne arts tot zijn diagnose geraakt. Is dit op een efficiente en effectieve wijze gebeurd? of zijn er kostbare en/of nutteloze omwegen bewandeld? Vaak wordt een tweetal modellen onderscheiden: het model gebaseerd op patroonherkenning en het hypothetico-deductieve model. Soms wordt een derde model onderscheiden; het zogenaamde "uitputtende" model, waarbij de arts min of meer ongericht gegevens verzamelt en op die manier volledigheid nastreeft. Van welk model de arts in de praktijk gebruik maakt bij het oplossen van diagnostische problemen is niet altijd nauwkeurig te bepalen. Het probleemoplossend model, dat iedere arts in iedere situatie hanteert, bestaat niet. Oplossingsstrategieên variëren naargelang de complexiteit van de casus, de urgentie van het probleem etc. en zullen derhalve vaak een mengeling van verschillende benaderingen zijn (Politser, 1982).

Recent onderzoek naar de toepassing van bitewing-foto's door de Nederlandse tandartsen laat zien dat ook in de tandartsen-praktijk weinig uniformiteit bestaat ten aanzien van de toepassing van diagnostische middelen. Het moet uitgesloten worden geacht dat besluitvorming uitsluitend plaatsvindt met behulp van een rationeel analytïsch model (Mileman e.a., 1986).

\section{Het "uitputtende" model}

Deze wijze van diagnostiseren wordt gehanteerd door de "postmoderne" arts van Shorter, de arts, die zoveel mogelijk informatie tracht te verzamelen. Hantering van dit model wordt vaak als oorzaak van overgebruik van diagnostische tests aangewezen. $\mathrm{Er}$ is een aantal praktische bezwaren aan te wijzen tegen hantering van dit model. De benadering gaat voorbij aan het feit dat anamnese en lichamelijk onderzoek reeds veel informatie opleveren over de ziekte (Hampton, 1975). Bovendien geeft een beperkt aantal goed gekozen tests soms meer informatie dan een gehele serie tests. Ook in deze sector speelt het fenomeen van het dalende grensnut, waarbij de toevoeging van nieuwe informatie aan de reeds bestaande informatie bij iedere test geringer wordt. Tenslotte kan een teveel aan informatie ook de aandacht afteiden van de meer essentiele informatie, waardoor de extra informatie contraproductief wordt. In situaties, waarin extra informatie goedkoop te verwerven is, kan een dergelijke "uitputtende" strategie toch zinvol zijn (Politser, 1981).

\section{Patroonherkenning}

Diagnostiseren door middel van patroonherkenning wordt ook wel de intuittieve benadering genoemd. Hierbij wordl ervan uitgegaan dat de arts min of meer automatisch op grond van de symptomen een ziektebeeld herkent bij de patient, hetgeen ook wel aangeduid wordt met "de klinische blik van de arts". Bij deze methode wordt uitgegaan van een grofmazig informatiesysteem, waarin steeds verfijnder wordt aangegeven met behulp van terzake doende informatie welke ziekte het betreft. Ter illustratie van het principe worden vaak visuele voorbeelden aangedragen waar het beeld herkend wordt zodra de informatie gedetailleerd genoeg is. Bij het diagnostiseren kan men zich voorstellen dat er ook hier een zeker niveau van gedetailleerdheid nodig 
is alvorens de arts de ziekte herkent op grond van de symptomen. Die methode zelf is in hoge mate subjectief (Gross, 1984).

Het gebruik maken van formele modellen, welke hieronder worden beschreven, wordt soms door artsen afgewezen op grond van het feit dat in deze modellen niet voldoende rekening wordt gehouden met de complexiteit, zoals die zich in werkelijkheid manifesteert. Echter de intuitieve benadering is vaak ook zeer incompleet. Opslag en gebruik van informatie is beperkt (Miller, 1981). De grootte van de steekproef wordt in intuitieve beoordelingen bijvoorbeeld vaak buiten beschouwing gelaten (Kahneman \& Tversky, 1974). Het fenomeen regressie naar het gemiddelde wordt vaak door artsen niet als zodanig herkend bij een abnormale testuitslag. Een aantal auteurs toont aan dat logische modellen vaak beter werken dan intuitieve benaderingen (De Dombal e.a., 1974). Vooral het combineren van informatie kan beter door computers geschieden (Elstein e.a., 1978).

\section{Het hypothetico-deductieve model}

De derde methode is de hypothetico-deductieve benadering. Aan dit model zal uitgebreid aandacht besteed worden, omdat het de meest gangbare benadering van het diagnostisch proces representeert. Door de logica die eraan ten grondslag ligt biedt dit model bovendien goede aanknopingspunten voor een evaluatieve benadering van het testgebruik. Overigens wordt de algemene geldigheid in twijfel getrokken.

In de eerstgenoemde "uitputtende" benadering wordt ervan uitgegaan dat de arts zo lang mogelijk blanco is wat betreft zijn verdenking op ziekten. Dit uitgangspunt wordt vaak ook in de medische opleiding gehanteerd waarbij van studenten wordt verwacht dat ze het formuleren van hypothesen uitstellen, in ieder geval tot na de anamnese en het lichamelijk"onderzoek (Elstein e.a., 1978). Indien artsen een groot aantal onbevooroordeelde observaties willen verrichten, alvorens een aantal hypothesen op te stellen (inductie) om vervolgens deze hypothesen achtereenvolgens te testen (deductie), dan kan dit leiden tot een geweldige verzameling van nutteloze gegevens. Goede probleemoplossers en ook ervaren artsen hanteren zelden dit principe (Campbell, 1976). Dit probleem wordt ondervangen in de hypothetico-deductieve benadering.

Hierbij worden bijna onmiddellijk bij het zien van de patient diagnostische hypothesen gegenereerd. Uit onderzoek blijkt dit binnen enkele seconden te gebeuren, nadat de hoofdklacht door de patiènt geuit wordt (Neufeld, 1985). Er is vastgesteld dat de arts in een vroegtijdig stadium op grond van een zeer beperkte hoeveelheid gegevens ( \pm 10 procent van het totaal) reeds een aantal hypothesen formuleert (Adelstein, 1982). Deze hypothesen worden nader onderzocht door gebruikmaking van tests. Via de hypothetico-deductieve wijze wordt de benodigde informatie op een logische wijze geselecteerd. Eerst worden hypothesen gesteld op grond van anamnese en lichamelijk onderzoek. Vervolgens wordt eventueel meer informatie verzameld via laboratoriumonderzoek, waarmee de hypothesen nader getoetst worden en waarbij ook nieuwe hypothesen gegenereerd kunnen worden.

In de volgende fase van het diagnostisch proces wordt getracht de meer waarschijnlijke hypothesen te bevestigen en de minder waarschijnlijke hypothesen uit te sluiten, waarbij, zoals reeds hiervoor werd opgemerkt, ook geheel nieuwe hypothesen kunnen ontstaan. Deze revisie van waarschijnlijkheden wordt in eerste instantie verricht op 
grond van klinisch onderzoek. Latere revisies komen op rekening van tests. Nadat respectievelijk via uitsluiten van minder waarschijnlijke hypothesen (ruling-out) en het bevestigen van de meer waarschijnlijke hypothesen (ruling-in) uiteindelijk de diagnose is gesteld, kan een begin gemaakt worden met therapeutische interventies. Alvorens met de therapie te beginnen, zeker in het geval dat deze gepaard gaat met risico's, is het nodig met behulp van "perfecte" tests definitief uitsluitsel te geven omtrent de aanwezigheid en de ernst van de ziekte. In onderstaand schema zal hiervoor de term "bevestigende tests" worden gehanteerd.

Ook in deze (therapeutische) fase zal veelvuldig gebruik gemaakt worden van tests; de management c.q. monitoring tests. In onderstaande figuur is getracht deze wijze van diagnostiseren en het daarmee samenhangende testgebruik weer te geven. Daarnaast bevat de figuur ook een aanduiding van de testcategorießn met betrekking tot screening en monitoring. Bij de samenstelling van het overzicht is gebruik gemaakt van Werner (1978), Burke (1981), Griner e.a. (1981) en Bennington (1981).

Figuur 1.1. Overzicht van het gebruik van tests en medische acties: een hypotheticodeductieve benadering

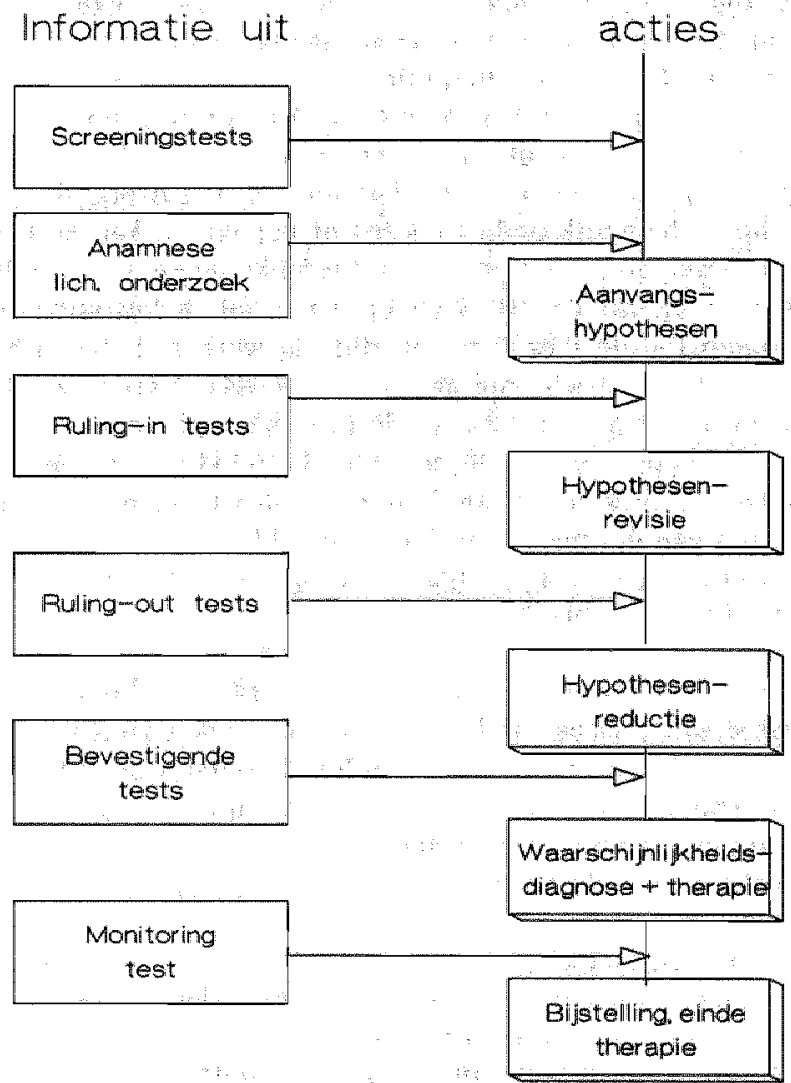


Op grond van klinische bevindingen (anamnese en lichamelijk onderzoek) wordt een aantal hypothesen opgesteld. Screening tests worden ook gebruikt in een fase dat er nog geen thypothesen over mogelijke ziekten worden gehanteerd. In feite wordt er bij screening min of meer impliciet vanuit gegaan dat de personen, die gescreend worden, niet ziek zijn. Vaak is het mogelijk om op grond van de verzamelde informatie aanvangshypothesen te formuleren. Indien er nog onvoldoende inzicht bestaat over mogelijke ziekten, kan ongericht laboratoriumonderzoek extra informatie hieromtrent aandragen. Het doel van tests in deze fase is om toch wooral geen belangrijke ziekte-oorzaken over het hoofd te zien (ruling-in tests). Wanneer op deze wijze alle mogelijkheden in kaart zijn gebracht moet het aantal mogelijke diagnoses worden teruggebracht tot een overzichtelijk aantal en uiteindelijk liefst tot Cen mogelijkheild met een zo groot mogelijke zekerheid.

Vervolgonderzoek is nu dan ook gericht op het uitsluiten wan mogelijke ziekte-oorzaken (ruling-out tests). Resteren na deze fase meerdere mogelijkheden dan moeten "bevestigende tesis" verder uitsluitsel geven. Indien hierbij de mogelijkheden in volgorde van waarschijnlijkheid worden afgelopen, spreekt Bennington (1981) over een zogenaamde "waarschijnlijkheidsbenadering". Uiteindelijk leidt dit tot een waarschijnlijkheidsdiagnose, waarop de behandeling kan worden geëntameerd.

In bovenstaande figuur is het medisch handelen teruggebracht tot een eenvoudig sequentieel gebeuren waarbij achtereenvolgens aandacht wordt besteed aan anamnese, lichamelijk onderzoek, diagnose en therapie.

Het is duidelijk dat in de praktijk bepaalde fasen kunnen worden overgeslagen. Zo zal bijvoorbeeld na een positieve testuitslag bij screening de behoefte aan een bevestigende vervolgtest zo groot zijn dat andere fasen kunnen worden overgeslagen. Voordat met de anamnese en het lichamelijk onderzoek wordt begonnen, kan er al sprake zijn van een aanvangshypothese. Soms zal met een therapie begonnen worden, voordat de diagnose gesteld is. Ook zal de arts zich opnieuw willen bezinnen op de diagnose, indien na verloop van tijd de therapie niet blijkt te werken, hetgeen aangeduid wordt met de differentiaal-diagnostische spiraal (Gross, 1984). Verder zal het onderscheid tussen ruling-out en bevestigende tests in de praktijk vaak vervagen. Sommige artsen zullen all heel vroeg bepaalde hypothesen met betrekking tot zeer ernstige ziekten willen uitsluiten. Deze representant van de minimax-least-loss benadering heeft tot doel de negatieve effecten van de meest ernstige mogelijkheid te minimaliseren. In handen van extreem risicomijdende artsen (zie verder hoofdstuk 3) kan deze strategie gemakkelijk leiden tot overgebruik van tests.

In de praktijk doen zich problemen van welerlei aard voor bij het hanteren van dit model. Soms vergissen artsen zich in logische redeneringen of maken foute kansschattingen (Cassells e.a., 1978). Ook worden de oorspronkelijke hypothesen soms gebaseerd op te weinig informatie, terwijl artsen nieuwe informatie, die nieuwe hypothesen zou kunnen genereren, verwaarlozen. Ook het omgekeerde komt voor: het teveel gewicht hechten aan nieuwe gegevens.

De oorspronkelijke hypothesen worden gegenereerd op grond van klinische bevindingen. Onderzoek heeft aangetoond, dat het aantal hypothesen, dat gedurende het diagnostisch proces simultaan wordt onderhouden, maximaal 5 à 7 bedraagt. In minder gecompliceerde gevallen wordt volstaan met 2 a 3 hypothesen. Volgens sommigen ligt hier het cruciale punt bij de beoordeling van de efficiency van het diagnostisch proces: het verschil tussen efficiënt en minder efficiënt diagnostiseren is het aantal benodigde hypothesen om tot een juiste diagnose te geraken (Wright \& MacAdam, 1982). 
Aangezien er verschillen geconstateerd worden in de wijze waarop artsen diagnostiseren doet zich de vraag voor welke manier de meest optimale is. Is het zo dat het aantal benodigde hypothesen om tot een juiste diagnose te geraken het verschil vormt tussen efficiënt en minder efficiënt? Een complicerende factor bij de beantwoording van deze vraag is dat de wijze van diagnostiseren situatiegebonden is en dus in de praktijk per casus kan verschillen (Elstein e.a., 1978).

Uit Nederlands onderzoek bleek dat het besliskundig proces van huisartsen meer overeenkomsten vertoont met de hypothetico-deductieve wijze van diagnostiseren, terwijl de internisten in dit onderzoek meer geneigd zijn tot een systematisch onderzoek met behulp waarvan achteraf de werkhypothesen worden getoetst. Het gemiddelde aantal werkhypothesen verschilt overigens niet tussen beide groepen (Gerritsma \& Smal, 1982). Verder zijn er aanwijzingen dat ervaren artsen anders diagnostiseren dan onervaren artsen. Onervaren artsen zijn veel meer geneigd op basis van gegevens hypothesen te genereren (het "uitputtende" model), terwijl ervaren artsen zo vroeg mogelijk naar hypothesen gaan (Elstein e.a., 1978).

Voor de evaluatie van het testgebruik, zowel in het diagnostisch proces als in de monitoring fase is het vereist om over een model te beschikken dat aangeeft hoe artsen tot hun beslissingen komen. Het hypothetico-deductieve model geeft dit op een ideaaltypische wijze weer. In de praktijk van het medisch handelen worden ook de overige modellen frequent gehanteerd (Wulff, 1980). De bepaling van de meest optimale wijze van diagnostiseren heeft ook een economische dimensie. Zo is de arts, die in staat is bijna onmiddellijk op grond van gegevens uit anamnese en lichamelijk onderzoek de juiste diagnose te stellen, zeer efficiènt bezig. Soms zal het nodig zijn om onmiddellijk na anamnese en lichamelijk onderzoek via een "bevestigende test" de ziekte aan te tonen. Vaak echter zal, ook al omdat "bevestigende tests" vaak duur zijn, in eerste instantie via goedkopere ruling-in en ruling-out tests vóorwerk verricht moeten worden om het pad te effenen woor het gebruik van de "bevestigende tests". De efficiency van het diagnostisch proces wordt in dit boek overigens niet besproken, well de efficiency van het testgebruik.

In dit boek staat de waarde van tests ter discussie. Tot de tests worden zowel de laboratoriumtests als ook de radiodiagnostische verrichtingen gerekend. Beide categorieën zijn middelen om informatie te leveren aan de arts. De laboratoriumtests zullen meer gebruikt worden in eerdere stadia wan het diagnostisch proces (ruling-in en ruling-out) dan radiodiagnostische tests welke meer betrekking hebben op de bevestigende diagnostiek.

\subsection{EVALUATIE VAN TESTS}

\subsubsection{Inleiding}

Het gebruik van tests kan op verschillende wijzen worden geëvalueerd. Hiervoor werd reeds aangegeven dat testgebruik in functie kan worden gezien van de diagnosestelling. Het uiteindelijke doel is echter het bevorderen van gezondheid en derhalve kan het nut van tests ook worden beoordeeld in functie van de te behalen gezondheidswinst. In een economische benadering ligt met name op deze laatste zienswijze de nadruk. Een test 
is dan te beschouwen als een onderdeel van het productieproces: een proces waarin schaarse middelen (arbeid en kapitaal) worden getransformeerd tot testuitslagen, die op hun beurt weer deel uitmaken van het productieproces in de gezondheidszorg.

Bij het totale productieproces zijn verschillende belanghebbenden betrokken. Dit zijn niet alleen de arts, als aanvrager van de test, en de patiẻnt, die om hulp komt vragen. Daarnaast zijn nog andere personen en instanties te onderscheiden. De leiding van het laboratorium, waar de test geproduceerd wordt, is verantwoordelijk voor de wijze van produceren van de test en voor het organisatorische en financiële management van het laboratorium, alsmede voor de ontwikkeling wan betere testprocedures. Bovendien hebben betalende instanties, waarvan de patiênt zelf ook weer deel uitmaakt, er belang bij dat de kosten van gezondheidszorg zo laag mogelijk blijven (hetgeen overigens niet impliceert dat ook het aantal tests zo gering mogelijk moet zijn).

Het productieproces van een test kan ook gezien worden als een informatieproces, waarbij de patiënt met bepaalde klachten hulp komt zoeken bij de arts. Deze arts zal vaak in onzekerheid verkeren over de werkelijke aard van de ziekte. Tests kunnen hierover informatie verschaffen zodat uiteindelijk doeltreffend therapeutisch ingrijpen mogelijk wordt. De test is dan een onderdeel van het communicatieproces tussen de arts en het laboratorium, waarbij er sprake is van een "syntactisch" niveau, een "semantisch" niveau en een "pragmatisch" niveau (Shannon \& Weaver, 1972).

Het syntactische niveau heeft betrekking op de laboratoriumuitslag en geeft aan in hoeverre een uitslag foutloos wordt geproduceerd en overgebracht naar de aanvrager: De eventueel gemaakte fouten worden omschreven als ruis (technical noise). Op een iets hoger niveau speelt de betekenis van de boodschap een rol: het semantische niveau. (How precisely do the transmitted symbols convey the desired meaning?) Een testuitslag heeft slech ts betekenis voorzover de ontvanger van het bericht er dezelfde betekenis aan hecht als de afzender van het bericht. Het derde niveau heeft te maken met de te ondernemen actie, volgend op een bericht d.w:z. het pragmatische niveau. Dit is het uiteindelijke doel van ieder bericht (Shannon \& Weaver, 1972).

Een alternatieve mogelijkheid is om de test meer te zien als een onderdeel van het productieproces: een proces waarin schaarse middelen (arbeid en kapitaal) worden getransformeerd tot testuitslagen, die op hun beurt weer deel uitmaken van het productieproces in de gezondheidszorg.

Naast bovengenoemde indelingen wordt ook vaak onderscheid gemaakt naar niveaus van effectiviteit (zie bijvoorbeeld Roberts, 1983):

\section{diagnostische effectiviteit}

De mate waarin de testuitslag het oordeel van de arts terecht beinnloedt. Betrouwbaarheid en validiteit zijn noodzakelijke voorwaarden voor diagnostische effectiviteit.

\section{therapeutische effectiviteit}

Draagt de test bij aan de besluitvorming ten aanzien wan het therapeutisch beleid? (Stillwell e.a., 1980). gezondheidseffectiviteit

Wordt de gezondheidssituatie van de patiënt in positieve zin beïnvloed? 


\section{- bevolkingseffectiviteit}

Draagt toepassing van de testprocedure op grote schaal bij aan het verbeteren van de gezondheidstoestand van de bevolking?

In dit boek is een indeling gekozen, die een aantal elementen in zich draagt van de bovengenoemde indelimgen.

Het eerste niveau heeft betrekking op het laboratorium, wal de test geproduceerd wordl. Wij zullen dit aanduiden met het "syntactisch niveau". Soms wordt dit ook wel aangeduid met de term "technisch" niveau (Van der Helm \& Hische, 1986). Hier wordt in de eerste plaats bekeken hoe met de inzet van zo weinig mogelijk middelen zo betrouwbaar mogelijke testuitslagen kunnen worden geproduceerd. Dit zal in paragraaf 1.4.2 verder worden uitgewerkt.

Indien de testuitslag de arts bereikt dan is de belangrijkste vraag hoeveel informatie deze testuitslag bevat over de patiènt. Op dit niveau wordt nog niet gekeken naar eventuele vervolgstappen, die door de arts genomen kunnen worden. Hier wordt de laboratoriumtest als een zelfstandig onderdeel van het totale productieproces beschouwd. Op dit niveau staat derhalve de "mate van informativiteit" van de test centraal. Deze "mate van informativiteit" wordt naast kenmerken van de test, proceskenmerken die bepaald zijn door het voorafgaande niveau, ook nog bepaald door kenmerken van de ziekte, zoals het vórkomen ervan (par. 1.4.3).

Het derde niveau is het effectiviteitsniveau. Hier wordt gekeken naar de mogelijke effecten van de testuitslagen, waartoe zowel de gezondheids- als de bevolkingseffectiviteit wordt gerekend. (par: 1.4.4).

\subsubsection{Het syntactisch niveau}

Het productieproces van tests binnen het laboratorium is te beschouwen als het produceren van informatie met behulp van inputfactoren als kapitaal en arbeid. Het produceren van de testuitslag dient op een efficiënte wijze te geschieden, đ.w.z. tegen zo laag mogelijke kosten Door Büttner (1978) wordt dit het meest basale niveau genoemd. Het laboratorium ontwangt een verzoek om een monster nader te onderzoeken en levert na onderzoek een uitslag. Om dit proces te evalueren is een aantal criteria denkbaar: het aantal geproduceerde tests, de productietijd, kosten per test, etc. Büttner denkt hierbij dus met name aan bedrijfseconomische parametters om de efficiency (in engere zin) van het laboratoriumproductieproces te bepalen.

De evaluatie kan naast deze bedrijfseconomische invalshoek ook gericht zijn op de kwalitatieve aspecten van het productieproces, die overigens hier niet besproken zullen worden. In het productieproces kunnen fouten ontstaan door allerlei oorzaken. Labora toriumbepalingen zijn onderhevig aan statistische fouten, procedurele fouten en menselijke fouten (Barr, 1981). Tenslotte rekenen we ook de betrouwbaarheid ${ }^{1}$ van tests tot dit syntactische niveau. De betrouwbaarheid van de meting zegt iets over de mate van consistentie van de meting (Neufeld, 1985). De betrouwbaarheid of reproduceerbaarheid kan kleiner zijn dan $100 \%$ door biologisch bepaalde variatie en door waarnemersvariatie, waarbij onderscheid gemaakt wordt tussen intra-waarnemer variabiliteit en

1) Synoniemen van betrouwbaarheid zljn: reproduceerbatirheid en precisile (precision) zie bijvoorbeeld Sackett (1975). 
inter-waarnemer variabiliteit (Sturmans, 1986). Indien de betrouwbaarheid gering is dan is de waarde van de meting per definitie zeer gering.

\subsubsection{Mate van informativiteit}

Nadat de test volgens de technische normen, zo betrouwbaar mogelijk en liefst tegen 20 gering mogelijke kosten, geproduceerd is, wordt de testuitslag gemeld aan de behandelende arts. Voordat de arts over gaat tot het incorporeren van de testuitslag in de besluitworming, zal voldaan moeten zijn an het criterium wan vallditeit. ${ }^{1}$ Onder validiteit wordt verstaan de mate waarin de test daadwerkelijk meet wat zij moet meten.

De validiteil geef dus aan de mate waarin de meting vrij is van systematische meetfouten (Sturmans, 1986). Een test is een methode volgens welke men beslist of de betrokkene al dan niet een bepaald kenmerk heeft. Een test is dus in abstracto een beslisregel. Bij het begrip validiteit gaat het er dan om in welke mate de test aanleiding geeft tot het terecht aanvaarden van de hypothese die zegt dat iemand ziek is, dan wel het terecht aanvaarden van de hypothese dat iemand niet ziek is.

Kenmerken die hetzelfde aangeven zijn de sensitiviteit (Se) en de specificiteit (Sp) van de test. De sensitiviteil geeft aan het gedeelte van de zieken dat door de test terecht als ziek wordt aangeduid. De specificiteit geeft aan het gedeelte van niet-zieken dat door de test terecht als niet ziek wordt aangeduid.

Over de relatie tussen validiteit en betrouwbaarheid kan het volgende opgemerkt

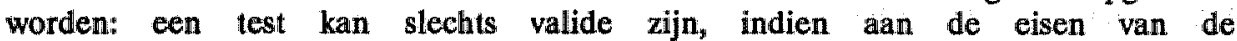
reproduceerbaarheid is voldaan. Reproduceerbaarheid is een noodzakelijke, doch niet voldoende, voorwaarde voor validiteit.

Sensitiviteit en specificiteit zijn belangrijke kenmerken van de test. Zij geven aan hoe goed de test in staat is om onderscheid te maken tussen zieken en niet-zieken, maar zij zijn niet de enige factoren, die de mate van informativiteit bepalen. Een test met een hoge sensitiviteit en specificiteit (dus hoge validiteit) kan in bepaalde situaties toch zeer weinig extra informatie opleweren. In situaties, waarin bijvoorbeeld sprake is van een zeer lage kans op de ziekte, is de uitspraak "iedereen is gezond" vrijwel altijd juist. De kans op een foute uitspraak is gelijk aan de (lage) kans op de ziekte. Ook bij zeer hoge kansen speelt hetzelfdle fenomeen een rol. Indien naar de informatiewaarde van de test wordt gekeken, is deze dus niet los te zien van de ziektesituatie, warop de test betrekking heeft. Potentieel kan de test de meeste informatie toewoegen in die situaties waar de onzekerheid, wat betreft het al of niet voorkomen van de ziekte, het grootst

1) Bewust is afgezien van het gebruik van de term accuraatheid. Vaak wordt de term accuraatheid (accuracy) gebruikt in de betekenis van validiteit: Zijn de verkregen meetresultaten een juiste weergave van datgene wat het meetinstrument wil meten? Een andere definitie van accuracy is te vinden in Metz (1978), waarbij hij het aantal goede uitspraken relateert aan het totaal aantal uitspraken. Dingnostische efficiency wordt in dezelfde betekenis gehanteend (Bennington, 1981). Card \& Emerson (1980) hanteren de term "degree of misclassification" woor de verhouding foute uitspraken ten opzichte van het totaal aantal uitspraken. Lissted (1978) hanteert de term "diagmostische bruikbaarheid". Deze diagnostische bruikbaarheid kan geevalueerd worden in termen van de informatie-inhoud of gemiddelde kosten en opbrengsten (zie par. 1.4.4). 
is. Dit is het geval wanneer alle mogelijkheden (in dit geval ziek zijn of gezond zijn) even waarschijnlijk zijn (Metz, 1978). Er zijn diverse methoden ontwikkeld waarmee de informatiewaarde van de test kan worden bepaald, in relatie tot de a priori kans op de ziekte, d.w.z. de kans op de ziekte voórdat de betreffende test is uitgevoerd. In de Bayesiaanse benadering wordt de a posteriori kans vergeleken met de a priori kans. Hoewel de principes van deze benadering in talloze publicaties, waarvan de eerste dateren uit de beginjaren zestig, zijn beschreven, lijkt de bekendheid ervan nog steeds onvoldoende te zijn onder artsen (Sheps \& Schechter, 1984). Op deze benadering wordt ingegaan in hoofdstuk 4 . In de informatietheorie wordt de onzekerheidsreductie, die op kan treden door uitvoering van de test, uitgedrukt in de eenheid "bit", een maat voor onzekerheid (zie voor uitwerking hiervan hoofdstuk 4 en 5).

\subsubsection{Het effectiviteitsniveau}

De test, geëvalueerd op het effectiviteitsniveau, geeft de arts nieuwe informatie en biedt mogelijkheden om beslissingen beter te funderen. De beslissing kan betrekking hebben op het aanvragen van nieuwe tests, het in gang zetten of bijsturen van een therapie of het stoppen van de therapie. Op dit niveau kunnen in principe twee aspecten onderscheiden worden. In de eerste plaats kan door uitvoering van de test een andere beslissing genomen.worden dan zonder de test het geval zou zijn geweest. Echter het kan ook zo zijn dat een identieke beslissing wordt genomen, maar dat degene die de beslissing neemt nu meer zeker is van de juistheid van deze beslissing.

Uiteindelijk dienen tests informatie op te leveren die bedoeld is om betere beslissingen te kunnen nemen over het behandelen van patiënten. De test(uitslag) kan er toe leiden dat de gezondheidstoestand van patiënten beïnvloed wordt en dus kan de test ook geëvalueerd worden in het licht van de bereikte gezondheidswinst bij de patiënt. Voor een goede vergelijking dient rekening gehouden te worden met de risico's en andere negatieve effecten van tests. Een variant op deze benadering wordt gehanteerd door Cavenaugh (1981). Deze auteur schatte de kostenconsequenties van foute testuitslagen. De gevolgen van foute uitslagen lopen uiteen van: "het verrichten van een onnodige herhalingstest" tot "permanente handicaps ten gevolge van onnodig medisch handelen". Indien het perspectief uitgebreid wordt en ook de kosten van diagnostiek en behandeling worden meegenomen, kan de kosten-effectiviteit van verschillende teststrategieën bepaald worden. Met behulp van kosten-effectiviteítsratio's kan bepaald worden welk alternatief de meeste opbrengst produceert tegen een bepaald bedrag aan kosten of door welk alternatief tegen de minste kosten een bepaalde hoeveelheid opbrengst kan worden geproduceerd. Indien de opbrengst wordt bepaald met behulp van waarderingsfactoren welke gestoeld zijn op zogenaamde utility-assessment methodieken dan is het in principe mogelijk alle vormen van gezondheidszorg onderling te vergelijken. Dit is het niveau van de kosten-utiliteitsanalyse (Drummond, 1987). In kosten-effectiviteits- en kosten-utiliteitsstudies zijn opbrengsten en kosten in verschillende eenheden uitgedrukt.

Met behulp van de betreffende ratio's kan het beste alternatief geselecteerd worden, maar kan niet bepaald worden of dit alternatief ook "de moeite waard" is. Indien de gezondheidswinst in geld wordt uitgedrukt, kunnen kosten en opbrengsten rechtstreeks met elkaar vergeleken worden en kan ook op deze laatste vraag antwoord worden gegeven. Daarmee zijn we dan aangeland op het terrein van de kosten-batenanalyse. 


\subsection{PROBLEEMSTELLING}

In dit onderzoek is het testgebruik door artsen onderwerp van studie, waarbij het testgebruik wordt bestudeerd vanuit een economische optiek. Het uitgangspunt van een economische analyse is de schaarste aan middelen. Dit impliceert dat de inzet van tests op een verantwoorde wijze dient te geschieden, waarbij met name gelet wordt op aspecten van doelmatigheid en doeltreffendheid van de ingezette middelen. Uitgaande van de beperkte middelen, die beschikbaar worden gesteld binnen de gezondheidszorgsector, dient er een zorgvuldige afweging te geschieden, teneinde een zo hoog mogelijke opbrengst in termen van gezondheid te bereiken. In dit opzicht wordt onder optimale gezondheidszorg verstaan die allocatie van middelen, waarbij het niet mogelijk is, gegeven het budget, meer gezondheid te produceren door eventuele reallocatie van middelen. De gegeven definitie van optimale gezondheidszorg komt overeen met een utilitaristisch standpunt. Het voornaamste doel is in deze optiek de verbetering van de doelmatigheid van het gezondheidszorgsysteem, waarbij andere aspecten, zoals verdelings-aspecten, minder aandacht krijgen.

Gelet op de schaarste aan middelen zal ook het gebruik van relatief goedkope middelen, zoals bijvoorbeeld tests, steeds meer beoordeeld moeten worden in het licht van de te behalen opbrengst.

De algemene probleemstelling luidt:

Wat is de bruikbaarheid van besliskundige methodieken om het testgebruik binnen de gezondheidszorgsector te optimaliseren?

Deze algemene probleemstelling is op een tweetal verschillende manieren nader uitgewerkt. De meer specifieke probleemstellingen luiden:

1. Door welke factoren, zowel aan aanbod-als aan vraagzijde, wordt testgebruik door artsen bepaald? Zijn de besliskundige methoden zodanig te ontwikkelen dat ze geschikt worden voor een economische evaluatie van testgebruik? Het testgebruik van artsen blijkt door talloze factoren beïnvloed te worden. Dit impliceert dat er in principe talloze strategieèn denkbaar zijn om het testgebruik te optimaliseren. Het blijkt dat vele strategieèn en combinaties van strategieën reeds in de praktijk zijn toegepast. Daarbij kan onderscheid gemaakt worden in strategieèn đie aangrijpen aan aanbodkant, het laboratorium, en strategieën die het aanvraaggedrag van artsen beinvloeden. Via een literatuurstudie is een overzicht samengesteld van factoren die beschouwd kunnen worden als de belangrijkste oorzaken voor het toegenomen testgebruik. In vervolg hierop is nagegaan wat bekend is over de mate van effectiviteit van de diverse strategieèn om het testgebruik te beheersen. Via deze literatuurstudie is een nadere plaatsbepaling gegeven van de mogelijkheid om via introductie van besliskundige methoden het testgebruik te optimaliseren.

2. Het hoofddoel van de onderhavige studie heeft betrekking op de tweede specifiekere doelstelling: de verdere ontwikkeling van besliskundige methodieken, waarmee het gebruik van tests kan worden geëvalueerd vanuit een "ex ante" standpunt. Evaluatie kan plaatsvinden vanuit een "ex ante" of een "ex post" standpunt. In het eerste geval zijn de evaluatie-activiteiten bedoeld om 
informatie te verzamelen over nog te nemen beslissingen. In het tweede geval vindt de beoordeling achteraf plaats.

Met behulp van dergelijke besliskundige methodieken kunnen van te voren uitspraken gedaan worden over de zimvolheid van toepassing van tests. De resultaten uit dergelijke analyses kunnen worden verwerkt tot voorschriften in de vorm van protocollen.

Aan deze probleemstelling is een tweetal aspecten te onderscheiden: een beschrijend aspect en een analytisch aspect.

- Beschrijvend aspect

De bruikbaarheid van de besliskundige methode hangt nauw samen met de mate van acceptatie ervan door de professie. Teneinde de mogelijkheid tot acceptatie van de verder te ontwikkelen methoden te vergroten is er in de eerste plaats een overzicht samengesteld van de belangrijkste besliskundige benaderingen met betrekking tot het testgebruik, waarbij zowel aan methoden, welke betrekking hebben op het proces (procesevaluatie) als ook op de uitkomsten (outcome evaluatie) aandacht is besteed. De acceptatie van de economische benadering zal toenemen naarmate de professie beter in staat is in te zien dat deze benadering logisch aansluit bij besliskundige technieken welke reeds meer bekendheid genieten. Door de wijze van presentatie van de onderscheiden benaderingen worden bovendien de eventuele tekortkomingen van respectievelijke methoden zichtbaar.

- Analytisch aspect

Op de tweede plaats is er een verdere uitwerking gegeven aan de besliskundige benadering vanuit de economische invalshoek. Kernpunt van de economische benadering is dat zowel aan de kosten als aan de opbrengsten aandacht wordt geschonken. Daarbij zijn twee optimalisatie criteria denkbaar:

het criterium waarbij het verschil tussen opbrengsten en kosten wordt gemaximaliseerd (criterium $\mathbf{O}-\mathbf{K}$ ),

het criterium waarbij de kosten gedeeld door de opbrengsten worden geminimaliseerd (criterium $\mathrm{K} / \mathrm{O}$ ).

In economische evaluatiestudies wordt vrijwel altijd uitsluitend volgens het laatste criterium geoptimaliseerd, aangezien kosten en opbrengsten in verschillende dimensies. worden weergegeven. Worden de opbrengsten in geld uitgedrukt, dan kan ook het eerst genoemde criterium worden gehanteerd.

Economische evaluatiemodellen werden verder ontworpen en toegepast op een drietal situaties:

- het bepalen van het optimale afkappunt,

- het bepalen van de waarde van teststrategieèn ten opzichte van de alternatieven "niets doen" en "onmiddellijk behandelen",

het bepalen van optimale teststrategieën bij twee onafhankelijke tests.

In deze drie gevallen blijkt de optimale oplossing sterk afhankelijk te zijn van het gehanteerde criterium. Alvorens de modeluitkomsten te gebruiken, bijvoorbeeld om protocollen met betrekking tot testgebruik op te stellen, dient nader onderzocht te worden in welke praktijksituatie deze protocollen worden gehanteerd. 


\subsection{OPZET STUDIE}

In hoofdstuk 2 wordt de rol wan het laboratorium besproken. Welke mogelijkheden zijn er vanuit het laboratorium denkbaar en haalbaar om tot beheersing van het testgebruik te komen? In hoofdstuk 3 wordt de rol van de arts in het medisch besliskundig proces besproken en zal ingegaan worden op beheersmogelijkheden van de kant van de medische professie.

In daar op volgende hoofdstukken worden de evaluatiemethoden besproken waarmee de effecten van tests geevalueerd worden in het licht van de onzekerheidsreductie, waarbij woorlopig afgezien wordt van eventuele gezondheidswinst. Het betreft hier vormen van procesevaluatie zoals die ontwikkeld zijn enerzijds vanuit de epidemiologie en medische besliskunde (hoofdstuk 4), anderzijds door de informatietheorie (hoofdstuk 5).

In hoofdstuk 6 wordt vervolgens de optiek van de economische benadering gekozen en wordt een evaluatiemodel beschreven dat als basis dient voor de volgende hoofdstukken. In dit model vormen diverse kosten- en opbrengstencomponenten de basis waarop de evaluatie wordt gebaseerd. Vervolgens wordt het model toegepast op het probleem: het bepalen van het optimale afkappunt bij een test. In de literatuur kunnen vele verschillende modelspecificaties worden aangetroffen, waarbij soms alleen kosten, dan weer alleen opbrengsten een rol spellen. Aan de ontwikkeling van de $\mathrm{K} / \mathrm{O}$ benadering wordt speciale aandacht gewijd.

In hoofdstuk 7 wordt de basis gelegd voor de economische evaluatie met betrekking tot tests waarbij de waarde van een test vergeleken wordt met de alternatieven "niets doen" of "onmiddellijk behandelen". Door de winst in termen van gezondheid te vermenigvuldigen met de walarde van één gezond levensjaar kunnen kosten en opbrengsten in eenzelfde eenheid worden uitgedrukt. Aan het probleem van het ontbreken van informatie over deze waarde wordt tegemoet gekomen door een gevoeligheidsanalyse over een groot scala van mogelijke waarden uit te voeren. Een bijkomend voordeel van deze benadering is dat nu een brug geslagen kan worden naar de besliskundige benaderingen voor het bepalen van de waarde van informatie, afkomstig uit de operations research.

In hoofdstuk 8 worden de tot nu toe ontwikkelde evaluatiemethoden toegepast in meer gecompliceerde praktijksituaties, waarbij er sprake is van twee tests, welke ieder verschillende afkappunten kennen. Doordat deze tests op verschillende wijzen (apart, in serie of parallel) kunnen worden toegepast ontstaat een groot aantal mogelijke teststrategiedn.

In voorafgaande paragrafen is aangegeven hoe bij de evaluatie van testgebruik rekening gehouden kmin worden met de economische dimensie. Toepassing van besliskundige technieken in de medische praktijk is niet eenvoudig. In hoofdstuk 9 wordt ingegaan op een aantal van deze problemen. Daarnaast wordt ingegaan op de invloed van de interne budgettering op het kosteneffectief handelen van artsen. Tenslotte wordt aangegeven langs welke wegen de ontwikkelde kennis bruikbaar gemaakt kan worden voor toepassing in het individuele besluitvormingsproces van de arts. 


\subsection{INLEIDING}

De afgelopen decennia heeft er een geweldige groel plaats gevonden in kennis en inzicht met betrekking tot pathofysiologische kenmerken van ziekten. Door het beschikbaar komen van meer verfijnde therapeutische mogelijkheden is niet alleen meer verfijnde diagnostiek noodzakelijk geworden, maar is er ook een grotere behoefte ontstaan aan tests waarmee het beloop van de ziekte in de therapeutische fase nauwkeuriger kan worden gevolgd. De ontwikkeling van diagnostische technieken heeft ertoe bijgedragen dat op dit moment veel nauwkeuriger kan worden aangegeven welke ziekte iemand heeft. $\mathrm{De}$ ontwikkeling van diagnostische en therapeutische mogelijkheden is evenwel niet evenredig geweest. Diagnostische mogelijkheden zoals bijvoorbeeld de CT en NMR zijn miet altijd vergezeld gegaan van even effectieve therapeutische strategieën.

De technologische ontwikkeling op het terrein van het laboratorium is gepaard gegaan met een kostenexplosie. Zo worden de kosten van klinisch-chemische laboratoria in de Verenigde Staten geschat op 7\% van de totale kosten van de gezondheidszorg, terwij1 het totaal van alle laboratoriumkosten op $10 \%$ wordt geschat (Fineberg \& Pearlman, 1982). Er komen steeds meer aanwijzingen dat de zogenaamde lichte technologie meer kost dan alle hoogwaardige technologieèn zoals $\mathrm{CT}$, open-hartchirurgie, nierdialyse etc. gezamenlijk. Bovendien heeft deze lichte technologie een grotere invloed op de stijging van de kosten in de gezondheidszorg (Moloney \& Rogers, 1979).

In Nederland wordt geschat dat de directe kosten van medische technologie in algemene ziekenhuizen in 1980 bijna $25 \%$ van de totale kosten hebben bedragen tegen $20 \%$ in 1972 (Groot \& Visinescu, 1982). Verder blijkt dat er binnen het totaal van technologische ontwikkelingen een meer dan proportionele stijging heeft plaats gevonden in de diagnostische technologieên. De laboratoriumkosten maken nu een substantieel deel uit van de totale kosten van gezondheidszorg. Voor de meeste Europese landen bedraagt het percentage 5 à $10 \%$ (Hjelm, 1983) terwijl dit voor de Verenigde Staten wordt geschat op minimaal 10\%. Het andeel van de laboratoriumkosten in de ziekenhuiskosten is vanzelfsprekend hoger en ligt in de buurt van de 20 a $25 \%$ (Bennington, 1981). Er zijn echter ook binnen de Verenigde Staten grote verschillen per ziekenhuis (Altshuler, 1981).

Een nadere analyse van het functioneren van laboratoria kan derhalve een belangrijke stap betekenen in het proces van kostenbeheersing in de gezondheidszorg.

In principe kan het laboratorium beschouwd worden als een antwoordsysteem (Hardwick e.a., 1981). Dit systeem kan uitgelegd worden in een aantal componenten:

De input, waaronder vraagfactoren worden verstaan. Deze vraag wordt geïnduceerd door de onderliggende gezondheidsproblematiek bij patiënten en wordt door artsen geformuleerd (zie hoofdstuk 3).

Het transformatieproces. Dit is het eigenlijke productieproces dat plaatsvindt in het laboratorium. Productiefactoren als arbeid en kapitaal worden omgezet in testuitslagen. 
- Deze uitslagen vormen de output van het laboratorium. Deze uitslagen worden vervolgens verwerkt in het diagnostisch en therapeutisch beslissingsproces van artsen dat zich verder buiten het gezichtsveld van het laboratorium voltrekt.

In dit hoofdstuk wordt het tweede aspect, het transformatieproces, onder de loupe genomen, waarbij met name gekeken wordt naar de efficiency vam het proces. Bij de beoordeling wan de kwaliteit van de laboratoriumproductie zijin er diverse aspecten te onderscheiden Zo kan de nadruk worden gelegd op kwalitatieve aspecten waarbij nagegaan wordt in hoeverre het product voldoet aan bepaalde technische normen (Quility Control). Anderzijds kan de nadruk gelegd worden op de mate van effectuviteit.

Daartoe zal eerst de ontwikkeling in de productie van laboratoria worden besproken en zal aangegeven worden welke factoren aan te wijzen zijn als oorzaken van de groei. Tenslotte zal besproken worden welke strategieên mogelijk tot een betere beheersing van de ontwikkelingen op het terrein van het laboratorium in de toekomst zullen leiden.

\subsection{GROAI LABORATORIUMPRODUCTIE}

De toename in de productie van ziekenhuislaboratoria is niet een typisch Nederlands fenomeen, maar wordt aangetroffen in vele ziekenhuizen in vele landen. Deze ontwikkeling is bovendien reeds decennia bezig. De Vries (1974) vermeldt een aantal studies uit de beginjaren zeventig met betrekking tot de stijging van de laboratoriumproductie. Grofweg kwamen de resultaten hierop neer dat de jaarlijkse stijging van de laboratoriumproductie $\pm 15 \%$ bedroeg. Verder blijkt dat de ontwikkeling vam het productieniveau in de jaren zeventig eerder een exponentieel verloop vertoont dan een lineair verloop. Het is dan ook interessant na te gaan hoe de laboratoriumproductie zich sindsdien ontwikkeld heeft.

Uit een NZI-studie blijkt dat in de jaren 1970-1980 de laboratoriumproductie (gemeten in Spaanderpunten ${ }^{1}$ ) meer dan verdrievoudigd is Hetzelfde geldt voor functie-onderzoek, terwijl bij de rỏntgendiagnostiek sprake is van bijna een verdubbeling van de productie. Gegevens met betrekking tot de meer recente ontwikkeling op het terrein van de laboratoriumproductie laten de volgende procentuele groei in aantallen zien (tabel 2.1). Per opgenomen patiënt is de toename van röntgen-en laboratoriumonderzoek zowel voor klimische als poliklinische patiënten de laatste jaren afgerwakt.

Uit de tabel blijkt in de eerste plaats dat de groei in de laboratoriumproductie reeds is gestopt, wórdat de budgetfinanciering in de ziekenhuizen werd ingevoerd. Dat de invoering van de budgetfinanciering zijn schaduwen vooruit geworpen heeft is denkbaar. Van de andere kant zijn er ook signalen dat er in de beginjaren tachtig een soort

1) Maat voor de hoeveellheid arbeid benodigd voor de productie wan een test, gebaseerd op, overigens verouderde, tijdsstudies. 
Tabel 2.1. Percentage toename ten opzichte van de voorgaande jaren van röntgenen laboratoriumonderzoek naar kliniek en polikliniek 1980-1985

\begin{tabular}{lcccc} 
Jaar & \multicolumn{2}{c}{ Kliniek } & \multicolumn{2}{c}{ PollkLlniek } \\
& Röntgen & Lab.prod. & Róntgen Lab. prod \\
& & & & \\
1980 & 0,1 & 9,0 & 0,1 & 9,0 \\
1981 & $-0,4$ & 3,8 & $-1,1$ & 1,2 \\
1982 & 2,4 & 2,9 & $-2,0$ & $-5,1$ \\
1983 & 0,0 & $-0,9$ & $-2,9$ & $-3,6$ \\
1984 & 0,7 & $-0,4$ & $-0,3$ & $-0,2$ \\
1985 & 0,7 & 0,0 & 0,0 & 0,0 \\
& & & &
\end{tabular}

verzadiging is opgetreden in de vraag naar laboratoriumtests (zie o.a. Hjelm, 1983; Showstack e.a., 1982).

Een andere vraag is of deze toename in laboratoriumproductie daadwerkelijk heeft geleid tot een meer efficiënte of meer effectieve behandeling van patiènten. De vraag is gemakkelijker te stellen dan te beantwoorden. Dat er sprake is van een negatieve samenhang tussen laboratoriumgebruik en gemiddelde verpleegduur is aannemelijk gemaakt door Griner (1978) en Sheeley \& Sherman (1976), maar is niet bevestigd in het onderzoek van Martin e.a. (1974). Een negatieve associatie tussen de laboratoriumproductie en de gemiddelde ligduur impliceert niet zonder meer een causaal verband. Leidt de verhoogde productie van laboratoriumtests tot het sneller stellen van de diagnose en dientengevolge een adequater therapeutisch ingrijpen, eventueel gevolgd door een eerder ontslag, of is het zo dat verkorting van de gemiddelde verblijfsduur leidt tot een intensiever diagnostisch handelen per verpleegdag? Op deze discussie zal in de volgende hoofdstukken dieper ingegaan worden.

In bovenstaande studies werd op het niveau van het ziekenhuis gekeken naar de relatie tussen de productie van het laboratorium en de productie van verpleegdagen waarbij niet gecorrigeerd werd voor de samenstelling van de patiëntenpopulatie. In de navolgende studies is nagegaan of er in de loop der tijd een toename valt te constateren in de productie van laboratoriumverrichtingen per diagnosegroep.

Scitowsky \& McCall (1975) tonen aan dat het aantal tests met betrekking tot bepaalde diagnosegroepen sterk is toegenomen in de jaren $1951 \mathrm{t} / \mathrm{m} \mathrm{1971.} \mathrm{Na} \mathrm{correctie} \mathrm{voor}$ inflatie vinden zij voor verschillende diagnosen kostenstijgingen, welke o.a. veroorzaakt zijn door toename van het aantal diagnostische en therapeutische procedures. De besparingen, veroorzaakt door verkorting van de gemiddelde verpleegduur, worden mér dan teniet gedaan door de kosten van deze extra procedures.

Showstack e.a. (1982) hebben in hun studie, die betrekking heeft op veranderingen tussen de jaren 1972 en 1977 , ook voor de ernst van de ziekte gecorrigeerd door de steekproeven uit de beide jaren op een groot aantal punten te vergelijken. Uiteindelijk blijkt het effect van deze correctie overigens gering: de conclusies van gecorrigeerde en 
ongecorrigeerde cijfers wijzen in dezelfde richting: toename van de laboratoriumproductie per diagnosegroep. Enkele relatief nieuwe diagnostische tests laten een grotere toename zien dan de wat meer ingeburgerde tests. Hieraan verbinden de auteurs de conclusie dat het gebruik van nieuwe diagnostische technologieën met name in de beginfase sterk toeneemt, maar dat na enige tijd het gebruik ervan stabiliseert: een fenomeen dat vaak wordt aangetroffen bij de diffusie van technologieën.

\subsection{OORZAKEN STIJGING IABORATORIUMPRODUCTIE}

\subsubsection{Inleiding}

De oorzaken van de geconstateerde toename in de laboratoriumprodictie kunnen zowel aan de vraagzijde als aan de aanbodzijde worden gevonden. Wat zich daadwerkelijk voltrekt is een ingewikkeld samenspel tussen vraag- en aanbodfactoren, waarbij de grote behoefte aan informatie de vraag naar tests genereert, maar waarbij aan de aanbodkant min of meer autonome ontwikkelingen plaatsvinden die op hun beurt de vraag vitlokken. De factoren aan de vraagzijde zullen in hoofdstuk 3 worden besproken, in deze paragraaf zal nader ingegaan worden op aanbodfactoren, waarvan er een tweetal meer in extenso zal worden behandeld.

Daarbij zal een onderscheid in macro- en microniveau worden gehanteerd. Op macroniveau zijn van belang factoren als: het overheidsbeleid ten aanzien wan aanschaf van apparatuur en aantrekken van personeel, de tariefstelling en de opleiding van artsen (De Vries, 1974). De lijst is zeker niet uitputtend en kan gemakkelijk uitgebreid worden met factoren als: technologische ontwikkelingen waaruit nieuwe, meer betrouwbare technieken beschikbaar komen, de grotere nadruk op preventie van ziekten en het vroegtijdig diagnostiseren van ziekten, de angst voor juridische aansprakelijkheid bij nalatigheid (Markel \& Mitchell, 1980), en de grotere mondigheid van de patiënt die de beste zorg eist (Burke, 1981).

Op microniveau onderscheidt De Vries factoren die spelen op het niveau van het ziekenhuis en factoren die spelen binnen het laboratorium zelf. Bij het ziekenhuisniveau horen factoren als: de wijze van beroepsuitoefening van artsen, de organisatie van het zickenhuis, de aanwezigheid van laboratoriumfaciliteiten, zowel naar omvang als naar kwaliteit, opnamescreening, structuurkenmerken als aantal bedden en opnamen.

Factoren die vanuit het laboratorium de productie kunnen beînvloeden zijn: automatisering en informatisering, het aanvraagformulier, woorlichting aan artsen door de leiding van het laboratorium, de organisatie van het laboratorium, maar zeker ook de servicegraad.

In deze paragraaf zullen twee aanbodsfactoren worden besproken welke een grote invloed hebben gehad op de toename van het aantal laboratoriumbepalingen. Deze twee factoren zijn:

- de wijze van financiering van het laboratorium (par. 2.3.2),

- de automatisering (par. 2.3.3). 


\subsubsection{Financiering}

Mede door het tot voor kort gehanteerde systeem van outputfinanciering in de Nederlandse gezondheidszorg bestond er nauwelijks behoefte aan een gedegen inzicht in de kostenstructuur van laboratoria. Dit betekende ondermeer dat men ook geen inzicht had in de financieeleconomische consequenties van stijgende laboratoriumproductie. Vergoedingen van laboratoriumproductie waren gebaseerd op Spaanderpunten. Meer gecompliceerde verrichtingen kwamen in aanmerking voor hogere vergoedingen, welke gebaseerd waren op tijdsstudies in 1952 verricht door het R.IV: onder leiding van dr. Spaander. Door de technologische ontwikkelingen in het laboratorium is dit systeem overigens achterhaald. Hoewel de vergoedingen voor de laboratoriumproductie weliswaar miet volledig kostendekkend waren, bleef uitbreiding van productie aantrekkelijk in financieel-economisch opzicht omdat de vergoeding per verrichting in ieder geval hoger was dan de marginale kostencomponent. In een dergelijk vergoedingensysteem gat er geen enkele incentive uit om de productie te beheersen. Het ontbreken van dergelijke beheersingsmechanismen moet als een belangrijke factor aangeduid worden voor de kostenstijging van laboratoria (Conn, 1985). In de Verenigde Staten lijkt overigens het laboratorium nog veel meer in staat te zijn geweest om tot een "profit centre" uit te groeien, aangezien de vergoedingen op een hoger niveau liggen. Uit onderzoek bleek, dat in een bepaald ziekenhuis de kosten van laboratoriumgebruik $19,3 \%$ van het totaal uitmaakten, terwijl de opbrengst $27,9 \%$ bedroeg (Conn, 1978). Inmiddels is door de invoering van de financiering op basis van DRG's ook in de Verenigde Staten de positie van het laboratorium veranderd van profit-centrum in een kostencentrum (Winkelman \& Hill, 1984).

Het is duidelijk dat een verhoogd inzicht in de kostenstructuur van het laboratorium een belangrijke voorwaarde is om een meer efficiënt gebruik van het laboratorium te bewerkstelligen. Dit verhoogde inzicht is in de laatste jaren daadwerkelijk ontstaan. Kostenstudies laten een aantal constante zaken zien. De indirecte kosten vormen een aanzienlijk deel van de laboratoriumkosten. Zo vindt Stilwell (1981) dat ongeveer de helft van alle kosten kan worden geclassificeerd als indirect. De marginale kosten met name daar waar automatisering heeft plaats gewonden liggen in de buurt van de 20 a $25 \%$. Verder constateert Stillwell dat een klein aantal tests (14 van de 60) het merendeel van alle kosten voor zijn rekening neemt $( \pm 75 \%)$. Verder zijn de kosten van het verzamelen van monsters groter dan de arbeidskosten van het uitvoeren van de tests. De kapitaalkosten zijn relatief laag omdat automatisering hogere productie mogelijk maakt. Dit houdt in dat de arbeidskosten nog steeds een aanzienlijk deel van de totale kosten van het klinisch-chemisch laboratorium vormen ( 50 a $60 \%$ ).

Leyten e.a. (1984) hebben een studie verricht naar de kostenstructuur van het laboratorium in een groot algemeen ziekenhuis, waarbij ook de indirecte kosten in de beschouwing zijn betrokken. De verdeelsleutels van de indirecte kosten naar hoofd-en hulpafdelingen zijn ontleend aan de NZI-methodiek. De kosten blijken sterk bepaald te worden door het jaarlijks aantal te produceren tests. Bij 10.000 bepalingen per jaar van een bepaalde test zijn de marginale kosten gering. Dit suggereert dat er grote "economies of scale" zijn te behalen.

Vermindering van het aantal aanvragen leidt niet tot een evenredige vermindering van de kosten. Finkelstein maakt enkele ruwe berekeningen omtrent de mogelijke besparingen in een klinisch-chemisch laboratorium bij het teruglopen van de vraag naar tests. In een laboratorium waar vrij weinig geautomatiseerd is blijkt $22,6 \%$ van de totale kosten als vaste kosten aangemerkt te kunnen worden. Het overgrote deel blijkt dus uit 
variabele kosten te bestaan, hetgeen uilzicht biedt op realisatie van aanzienlijke kostenbesparingen (Finkelstein, 1978, 1980, 1982).

De kostenstructuur van het laboratorium en met name de verhouding tussen vaste en variabele kosten spelen een rol van betekenis. Naarmate de variabele kosten geringer zijn; is ook de cconomische prikkel om minder an te vragen geringer. In sterk geautomatiseerde laboratoria is zulks meer het geval (zie par. 2.3.3).

Op het terrein van de financiering zijn zowel in de Verenigde Staten als in Nederland in de afgelopen jaren interessante ontwikkelingen op gang gekomen, die cen grote invloed kunnen hebben op de toekomstige kostenontwikkeling. In de Verenigde Staten betreft het de invoering van financiering op basis van Diagnosis Related Groups (DRO), in Nederland de invoering van budgettering.

De "prospective reimbursement" systematiek in de Verenigde Staten, gebaseerd op DRG"s, heeft owerigens voomamelijk betrekking op de Medicare patiënten. Deze wijze wan financiering houdt in dat het ziekenhuis een vooraf bepalald bedrag krijgt voor een patient un een bepaalde diagnosegroep. Het ziekenhuis heeft in een dergelijke situatie financieel belang bij een zo efficient mogelijke behandeling inclusief het gebruik van het laboratorium. Door de invoering van een dergelijke financieringsstructuur is de prikkel tot overbodig laboratoriumgebruik in ieder geval weggenomen.

Overigens wordt ook steeds duidelijker dat aan een dergelijke financieringswijze nadelen kleven. Genoemd kunnen worden: de mogelijke reductie van de kwaliteit van zorg, selectie van "rendabele" patienten en de fraudegevoeligheid van het systeem.

Eenzelfde restrictieve werking kan bewerkstelligd worden door invoering van een budgetteringsstructuur zoals die in Nederland bestaat. Ook dan liggen de financiele middelen min of meer van tevoren vast en bestaat er een zekere druk om de productie van laboratoria niet te laten groeien. Onder invloed van de budgettering is ook een grote behoefte ontstaan aan de ontwikkeling van methodieken om het kosteninzicht binnen laboratoria te vergroten (Broughton \& Hogan, 1981). De besparingen verkregen uit en efficiènter laboratoriumgebruik komen nu ten goede aan de ziekenhuisorganisatile.

\subsubsection{Automatisering}

Automatisering is ongetwijfeld een van de meest besproken items op het terrein vam de kosten van het laboratorium. Doel van automatisering is o.a. het terugdringen van de arbeidskosten in het laboratorium. Geantomatiseerde laboratoriumsystemen slagen er inderdaad in de productiekosten woor veel tests te verlagen. Door automatisering kan een groot aantal tests op grote schaal tegen geringe kosten worden geproduceerd. Anderzijds kan gesteld worden dat door de ontwikkeling van geautomatiseerde systemen de vraag naar laboratoriumtests is opgeroepen hetgeen anders niet of niet in die mate zou zijn geschied. Onderzoeken warin de invloed van automatisering op de kostenontwikkeling wordt nagegaan op basis van historisch cijfermateriaal geven dan ook geen definitief uitsluitsel. Tydeman e.a. (1983) trachten in hun studie over de ontwikkeling van de laboratoriumkosten in een Canadees ziekenhuis in de zeventiger jaren de invloed van automatisering vast te stellen. Gedurende het betreffende decennium zijn de voor inflatie gecorrigeerde laboratoriumkosten per opgenomen patï̈nt gestegen van $\$ 44$ (Canadese) tot $\$ 116$. Verreweg de belangrijkste oorzaak is het gestegen aantal tests per opname. De automatisering blijkt zelfs een negatief effect op de kostenontwikkeling te hebben. 
Finkelstein (1978) heeft een inventariserend onderzoek verricht waarbij in totaal 204 ziekenhuizen zijn betrokken. Gedurende een periode van acht jaar zijn de maandelijkse hoeveelheden laboratoriumtests van deze ziekenhuizen bekend. Grote verschillen vielen te constateren in het gebruik van laboratoria. In de onderzoeksperiode van 1969 tot 1977 steeg het testvolume met gemiddeld $143 \%$, het meest bij de bacteriologie (150\%) en het minst bij de haematologie (134\%). Bij de bacteriologie was zowel bij de beginmeting als bij de eindmeting geen sprake van automatisering, dit in tegenstelling tot de haematologische laboratoria. Hieruit concludeerden de onderzoekers dat de stijging van het testgebruik meer betrekking had op het aanvraaggedrag van artsen dan dat dit in relatie kon worden gebracht met automatisering. Een conclusie die juist is voorzover het de bacteriologie betreft, maar voorbarig is met betrekking tot de ontwikkeling in de haematologische laboratoria. Zoals gezegd kan op deze wijze niet worden nagegaan wat de invloed is van automatisering op de ontwikkeling van de vraag en wordt de invloed van automatisering onderschat. De conclusie luidt dan ook dat het integrale effect van automatisering op de kosten van het laboratorium onbekend is.

De vergaande automatisering van het laboratorium is te beschouwen als een technologisch antwoord op een klinisch probleem. Wanneer in een laboratorium te veel nadruk wordt gelegd op de doelstelling: het produceren van een zo compleet mogelijk assortiment van tests, zo snel mogelijk en kwalitatief op een hoog peil, dan is een technologische oplossing in de richting van automatisering snel gevonden.

Het volgen van dit "technologische imperatief" is te bekritiseren voorzover geen rekening wordt gehouden met de marginale waarde van tests, voorzover de verouderde technieken naast de nieuwe blijven voortbestaan, en voorzover de arts niet wordt geïnstrueerd hoe de nieuwe technieken gebruikt dienen te worden, waarbij kosteneffectiviteitsoverwegingen mede een rol behoren te spelen.

Een aantal van de belangrijkste gevolgen van automatisering wordt in deze paragraaf besproken. In de eerste plaats wordt ingegaan op de mogelijke gevolgen van de verlaging van de productiekosten. De verlaging van de productiekosten heeft daarnaast ook de mogelijkheid geopend tot de ontwikkeling van een nieuwe laboratoriumfunctie, nl. screenen. Tenslotte zal ingegaan worden op de optimale grootte van het laboratorium onder invloed van de automatisering.

\section{Productiekosten bij automatisering}

Automatisering heeft tot gevolg dat meer testuitslagen kunnen worden geproduceerd tegen geringere kosten. Bestond er vroeger een bijna rechtlijnig verband tussen de kosten en het aantal geproduceerde tests, na de automatisering is er een daling opgetreden in de kosten per bepaling naarmate er meer geproduceerd wordt.

In de vorige paragraaf is reeds gewezen op het onderzoek van Leyten e.a. (1984), waarin op empirische gronden een grens van \pm 10.000 bepalingen op jaarbasis werd bepaald waarbij de marginale kosten zeer gering worden.

Horvath e.a. (1985) wijzen erop dat er in een reeds geautomatiseerde omgeving geen groot effect te verwachten is van het aanvragen van minder tests op de laboratoriumkosten. De kosten zijn in dat geval niet of nauwelijks afhankelijk van het aantal tests, tenminste zolang de workload in het laboratorium groot is. In het betreffende laboratorium werden de tests uitgevoerd door de SMAC (sequential multi-analyser computer), bijna $50 \%$ goedkoper dan uitvoering wan de tests apart. In de minder drukke uren (avond, nacht en weekend) is de workload echter zo gering dat tests wel 
apart worden uitgevoerd. De kosten worden dan hoofdzakelijk bepaald door de noodzakelike aanwezigheid van een personeelslid, waardoor ook in dat geval de marginale kosten gering zijn. Met andere woorden in geautomatiseerde laboratoria is het effect van een verminderde aanvraag van laboratoriumtests op de kosten uitersit gering.

De invloed van automatisering op de totale kosten is niet volledig bekend. Soms leidt het gebruik van automatisering weliswaar tot een daling van de totale testkosten (Lehmann \& Leiken, 1984), maar conclusies kunnen pas getrokken worden indien ook de overige behandelingskosten in de beschouwing worden betrokken.

Een andere vraag is of de verkregen extira informatie wel zinvolle informatie is. Uit een studie van Klatt e a. (1982) blijkt het opnemem van de CK-test (Creatine Kinase) in een meervoudige test (panel) geen extra informatie op te leveren over de aan- of afwezigheld van een hartinfarct.

\section{Sereening}

Het kunnen witwoeren van tests op grote schaal tegen geringe kosten heeft geleid tot een nieuwe functie van het laboratorium namelijk screening; screening kan gezien worden als het opsporen van ziekte bij in principe gezonde personen waar nog geen uiterlijk waarneembare tekenen van eventuele ziekten aanwezig zijn. In hoofdstuk 1 zijn diverse vormen van sereening reeds besproken. Hieronder zal nader ingegaan worden op een speciale vorm van screening, de laboratoriumscreening, waarbij de screening plaatsvindt op basis van bloed- of urinemonsters door middel van een batterij tests.

Screenen kan geschiedlen in de open bevolking (multiphasic thealth screening) of bij opname in een ziekenhuis (opnamescreening). De eerstgenoemde vorm van screening heeft meer tot doel het reduceren van de morbiditeit en/of mortaliteit. De tweede vorm is meer gericht op een verbetering van de efficiency van het medisch handelen.

De volgende overwegingen spelen bij evaluatie van multiphasic health screening een rol (Werner \& Altshuler, 1981):

De incrementele kosten van een extra test zijn laag, waardoor uitvoering van een groot aantal tests tegelijkertijd vanuit economisch oogpunt interessant is. Het blijft echter een onopgelost probleem welke combinatie van tests als optimaal besehouwd moet worden. Volgens Dixon \& Laszlo (1974) wordt uit de totale bulk aan informatic slechts ongeveer $50 \%$ daadwerkelijk gebruikt.

Indien de prewalentie van de ziekte laag is in de onderzochte populatie, hetgeen bij multiphasic health screening per definitie het geval is, dan is de voorspellende waarde van een positieve uitslag van de test uiterst gering (zie hoofdstuk 4). Dit leidt dan tot een relatief groot aantal herhaaltests om deze gezonde personen er weer uit te zeven.

Ter illustratie moge het volgende dienen. Bij hantering van een $95 \%$ betrouwbaarheidsinterval heeft een gezond persoon een kans van $5 \%$ dat hij toch een positieve testuitslag krijgt. Bij meerdere onafhankelijke tests neemt deze kans toe. Indien a het onbetrouwbaarheidsniveau is en $\mathbf{N}$ het aantal

tests, dan kan met behulp van de volgende formule de kans $p$ op én of meerdere afwijkende uitslagen worden berekend: 


$$
p=1-(1-a)^{N}
$$

Bij 6 tests is de kans op een afwijkend testresultaat bijwoorbeeld $26 \%$ en bij 20 tests $64 \%$.

In werkelijkheid zullen de gebruikte tests niet geheel onafhankelijk wan elkaar ziljn en kunnen de percentages lager uitvallen. In een experiment bedroegen deze percentages bij de SMA-8 $25 \%$ en bij de SMA-20 45\%, hetgeen zeer dicht in de buurt ligt van de woorspelde waarde (zie boven). Dat de kosten van vervolgtests dan sterk kumnen oplopen behoeft geen betoog.

Er zijn waarschijnlijk weinig medische procedures die zo terdege zijn geẻvalueerd als de bovengenoemde vorm van screening. Zo zijn de resultaten bekend van een zestal gerandomiseerde onderzoeken, waarvan er een betrekking had op meer dan 7,000 patiënten en een follow-up periode van 10 jaar (Durbridge \& Edwards, 1978). De conclusie luidt dat er geen bewijs geleverd kan worden dat multiphasic health screening leidt tot gezondheidsverbetering, een conclusie die ook door Joly (1982) wordt onderschreven. Dergelijke studies hebben het aanvankelijke enthousiasme over deze vorm van screening danig getemperd en in Nederland heeft multiphasic health screening dan ook geen algemene ingang gevonden.

Bij opnamescreening wordt een groot aantal tests als standaard work-up verricht bij opname in het ziekenhuis. Het doel is om zo snel mogelijk de beschikking te hebben over zoveel mogelijk relevante informatie teneinde de diagnose te stellen en hierop de behandeling te baseren. Ook hier is er geen bewijs geleverd dat de opnamescreening leidt tot vermindering van sterfte en/of morbilditeit (Durbridge e.a., 1975), maar anders dan bij "multiphasic health screening" zou het primaire doel bij opnamescreening kunnen liggen op het terrein van efficiency verbetering van het medisch handellen. Of deze efficiency-verbeteringen bereikt kunnen worden, hangt in sterke mate af van het type patiènt. Invoeren van opnamescreening voor alle patiënten lijkt een kostbare zaak (Bennington, 1981). Invoering voor bepaalde typen patiënten kan tot belangrijke tijdwinst leiden. Bij opnamescreening wordt de roll van de arts bij het selecteren van diagnostische tests teruggedrongen. Dit sluit aan op een manier van diagnostiseren welke in het voorgaande hoofdstuk is aangeduid met het "uitputtende model", het ongericht verzamelen van diagnostische gegevens. De zinvolheid van een dergelijke handelwijze dient van geval tot geval bekeken te worden.

\subsection{BEHEERSINGSSTRATEGIEEN}

\subsubsection{Inleiding}

In de navolgende paragraaf zal ingegaan worden op de mogelijkheden om de ontwikkelingen op het terrein van het laboratorium in goede banen te leiden. Daarbij wordt niet gestreefd naar volledigheid, maar worden de belangrijkste mogelijkheden aangegeven. Met name maatregelen welke betrekking hebben op de aanbodkant zullen worden besproken, waarbij enige overlap met het volgende hoofdstuk overigenss niet is te vermijden aangezien sommige aanbodstrategieżn tevens de vraag beïnvloeden. Er zijn diverse beheersingsstrategieên denkbaar. Winkelman \& Hill (1984) onderscheiden een viertal strategieën: 
- zuivere kostenbeheersing binnen het laboratorium,

- vermindering van dienstverlening,

- beinvloeding van aanvraaggedrag vanuit het laboratorium,

- reorganisatie van het laboratorium.

De verschillende maatregelen zullen worden besproken naar aggregatieniveaw. Zo kan gedacht worden aan de reorganisatie van het laboratorium in de zin van invoering van commerciele elementen, waarbij schalvergroting een logisch gevolg kan zijn. Vervolgens zal binnen de laboratoriumorganisatie zelf gekeken worden of er efficiencyverbeteringen haalbaar zijn. Tenslotte zullen die strategieen worden bekeken welke gevolgd kunnen worden vanuit het laboratorium en welke primair tot doel hebben de aanvraag van laboratoriumbepalingen te beperken.

\subsubsection{Het laboratorium op commerclele leest}

In de huidige gezondheidszorgstructuur zijn er in diverse sectoren elementen wan commercile aanwezig, waarbij niet alleen te denken valt aan de geneesmiddelensector, maar aan alle sectoren waar vrije beroepsbeoefenaren aan verbonden zijn. Tussen de non-profit organisatie aan de ene kant en de for-profit organisatie aan de andere kant zijn tussenvormen denkbaar (Evans, 1984). De not-for-profit organisatie bijvoorbeeld kan de eventuele overschotten alanwenden binnen de eigen organisatie. Deze vorm is van toepassing op de huidige ziekenhuissector. De not-only-for-profit vorm is een goede omschrijving van het functioneren van de vrije beroepsbeoefenaren binnen de gezondheidszorg. Voorzover zij een inkomen verwerven groter dan de arbeidskosten (van hun eigen geinvesteerde tijd) is er ook hier sprake van een overschot waar vrij over kan worden beschikt.

Het laboratorium was tot voor kort te beschouwen als een profit-centrum binnen de ziekenhuisorganisatie. $\mathrm{Na}$ invoering van de budgettering is het laboratorium deze status kwijtgeraakt en wordt het door het ziekenhuismanagement meer gezien als een kostenpost waar zoweel mogelijk op bezuinigd moet worden. In deze situatie wordt de vraag actueel of een laboratorium op commerciele basis niet minimaal in stat is tegen dezelfde kosten eenzelfde dienstverlening te bereiken als het "eigen" laboratorium.

Momenteel is het gebruikelijk dat ieder ziekenhuis de beschikking heef over laboratoriumfaciliteiten. Het is de vraag of dit de meest efficiênte wijze is om tests te produceren. leder ziekenhuis zall naar verwachting wel faciliteiten moeten hebben om Cito-bepalingen te kunnen verrichten, maar geldi dit ook voor het merendeel van de tests waar tijd een minder belangrijke rol speelt? Met name dit gedeelte van het laboratorium is aantrekkelijk voor een meer commerciele wijze van produceren. Zoals in dit hoofdstuk eerder is aangegeven zijn or in principe economische voordelen te behalen bij de productie indien deze op grote schaal kan geschieden $( \pm 10,000$ verrichtingen op jaarbasis). Dit betekent tevens dat boven dit aantal verrichtingen er nauwelijks meer voordelen zijn te behalen louter en alleen op grond van het centraliseren van de productie. Wanneer het erom gaat het laboratorium te dwingen tot een meer efficiënte productiewijze kan men ook besluiten tot een wal grotere verzelfstandiging van het laboratorium, waarbij het eigen laboratorium moet concurreren in prijs en kwaliteit van dienstverlenimg met andere laboratoria van ziekenhuizen zonder tot volledige privatisering ervan over te gaan.

De uitvoering van tests op regionaal niveau, is slechts mogelijk voor bepaalde gedeelten wan het testarsenaal. Het ontslaat het ziekenhuis niet van de verplichting om bijvoor- 
beeld spoedprocedures zelf te blijven doen, evenals de arbeidsintensieve procedures die niet geautomatiseerd kunnen worden (Conn, 1978).

In de Verenigde Staten blijkt dat commerciële laboratoria in een sterke concurrentiestrijd gewikkeld zijn geweest om de gunst van de arts. Deze laboratoria hebben vaak kortingen toegepast bij afname van grote hoeveelheden tests, hetgeen de arts ertoe aanzet meer tests te gebruiken dan nodig (Benson, 1978). Voor de Nederlandse situatie lijkt commercialisering van laboratoria geen wenselijke ontwikkeling. Het is bovendien niet nodig, aangezien er door de huidige financieringswijze incentives zijn ingebouwd voor een meer efficiënte productiewijze.

\subsubsection{Bedrijfseconomische maatregelen}

Bij een beheersing van de kosten van een laboratorium is inzicht in de kostenstructuur en kennis van de kostprijs essentieel. Het is dan ook niet verwonderlijk dat op dit moment naarstig wordt gezocht naar methoden om kostprijzen te bepalen van de activiteiten die verricht worden binnen ziekenhuizen en dus ook binnen laboratoria. $\mathrm{De}$ ontwikkelingen op dit terrein zijn in een stroomversnelling geraakt onder invloed van de budgettering. Door het verwisselen van een financiering op basis van output door een budgetfinancieringssysteem is een gedegen inzicht in de kostprijzen van verrichtingen en diensten veel essentiëler geworden. Dit heeft geleid tot een hernieuwde belangstelling voor allerlei kostprijsbenaderingen en kostenverbijzonderingsmethodieken.

In het kostenverbijzonderingsproces zijn drie fasen te onderscheiden. In de eerste fase worden de directe kosten van hulp-en hoofdafdelingen bepaald, in de tweede fase wordt per afdeling gezocht naar zinvolle kostendragers en in de derde fase worden de aldus bepaalde kosten toegerekend aan de verschillende specialismen en of patiëntengroepen. Kostprijsbepalingen kunnen worden gebruikt ten behoeve van de interne budgettering, maar ook voor externe doeleinden. Zo kan onderlinge vergelijking van de kostprijs van laboratoriumproductie interessante informatie opleveren over de mate van efficiency van het productiesysteem, zeker indien hierbij ook de mate van automatisering wordt betrokken.

Het bepalen van de optimale automatiseringsgraad van het laboratorium is een interessant probleem. Door meer gebruik te maken van geautomatiseerde systemen kunnen grote hoeveelheden tests worden geproduceerd tegen geringe kosten en kunnen gelijktijdig tests worden uitgevoerd tegen geringe extra kosten. Is vergaande automatisering het antwoord? Bij deze ontwikkeling is een aantal kanttekeningen to plaatsen. Juist door het feit dat de kosten per eenheid gering zijn na automatisering, tenminste als de volledige capaciteit wordt benut, ontstaat een zekere aanzuigende werking op de vraag. Voor de arts is er nauwelijks een reden te bedenken om eventuele extra tests niet aan te vragen. Ook vanuit het laboratorium zijn er vervolgens geen incentives meer aanwezig om het aantal tests te beperken, omdat de marginale kosten zo laag zijn. Indien een onkritisch gebruik gemaakt wordt van het geautomatiseerde laboratorium zullen vele positieve uitslagen aanleiding kunnen geven tot vervolgtests, welke de terecht-positieve moeten scheiden van de fout-positieve uitslagen (zie hoofdstuk 4).

Bij de invoering van geautomatiseerde systemen in het laboratorium is het reesler om de werkelijke kosten te schatten aan de hand van het aantal "informatieve" 
testresultaten dan uit te gaan van de kosten per geproduceerde test. Het begrip informatieve test zal later worden ingevuld.

Een madere studie naar het verloop van de kosten in het laboratorium is erg belangrijk, zeker indien men het testvolume wil terugdringen. In hoeverre de laboratoriumkosten reageren op deze verminderde aanvraag zou onderwerp van nadere studie moeten zijn, waarbij yerschillende configuraties van geautomatiseerde technologie in de beschouwing moeten worden betrokken.

\subsubsection{Niet-financiele drempels}

De hieronder te noemen maatregelen hebben tot doel de vraag naar laboratoriumtests. te beinvloeden door de toegankelijkheid van het laboratorium te verminderen. De gedachte hierbij is dat zolang het laboratorium kosteloos informatie levert aan de specialist, die zich geen enkele moeite hoeft te getroosten om deze informatie te verwerven, het laboratorium overstelpt zal blijven met aanvragen. Voor het inbouwen van drempels zijn er diverse alternatieven. De meest voor de hand liggende is wellicht het aanvraagformulier aanpassen. Men kan echter ook een restrictief beleid voeren ten aanzien van bepaalde dure tests.

Tenslotte kan men ook vereisen dat de aanvragen dienen te geschieden volgens vooraf overeengekomen procedures.

De veel gebruikte vorm van het aanvraagformulier waarbij artsen slechts hoeven aan te kruisen welke tests zij uitgevoerd willen hebben, is een open invitatie tot overgebruik. De betekenis van de vorm van het aanvraagformuller voor het aanvraaggedrag van artsen wordt duidelijk gemaakt in het hieronder beschreven experiment (Wong e.a, 1983). Het experiment is bedoeld om het gebruik van tests terug te dringen. De onderzoekers hebben ontmoetingen georganiseerd tussen artsen en laboratoriumartsen om een zekere consensus te bereiken omtrent een optimaal aanvraagpatroon. Vervolgens is deze consensus meegedeeld aan de medische staf via laboratoriumbulletins. Bij twee tests (CK en LDH) heeft men het daarbij gelaten in het experiment. Met betrekking tot vier thyroidfunctietests ontwikkelde men een additionele strategie. De verandering die aangebracht is betreft het aanvraagformulier waar voorheen de vier tests, naast de overige, nevenschikkend zijn gepresenteerd en waar de arts gemakshalve overal kruisjes zet. De nieuwe indeling van het formulier was gebaseerd op functies van tests. De opvoedkundige strategie allén blijkt geen effect te sorteren, maar in combinatie met de verandering in het aanvraagformulier blijkt dat de aanvraag van een tweetal tests drastisch is gereduceerd. Overigens mag uit dit onderzoek niet geconcludeerd worden dat de aangetoonde vermindering uitsluitend toe te schrijven is aan de verandering van het aanvraagformulier. Wellicht is de voorafgaande opvoedkundige strategie een noodzakelijke voorwaarde.

Ook de Gezondheildsraad (1986) gaat in op het effect van het aanvraagformulier op het aanvraaggedrag en suggereert om een blancoformulier te gebruiken.

"Een blanco formulier .... heeft in leder geval het voordeel dat de annvrager niet meer kan verzoeken dan de eigen kennis reikt."

Een nadeel van deze benadering is dat wellicht ook de nuttige tests achterwege worden gelaten. Het ligt derhalve meer voor de hand om het aanvraagformulier te zien als een 
besluitvormingsondersteunend middel, zoals dat in het experiment van Wong ea. het geval is.

Een methodiek, waarbij eveneens de zinvolheid wan de aanvraag ter discussie staat, is de aanvraag volgens het principe van "gestructureerde complexiteit". De intensiteit van het laboratoriumonderzoek wordt dan opgevoerd, naarmate de complexiteit van de situatie toeneemt. Dit proces is toepasbaar op alle fasen van het diagnostisch proces (zie hoofdstuk 1). Hardwick ea. (1982) beschrijwen een experiment om de kosten in het laboratorium te beheersen, uitgaande van deze methode. Gedurende de onderzoeksperiode daalt het totaal aantal tests met $15 \%$. Bij ongewijzigd beleid zou het aantal tests vermoedelijk met $\pm 15 \%$ aijn gestegen, zodat het totale effect becijferd is op 30\%. Andere voorbeelden van succesvolle experimenten om tests te gebruiken, alnaargelang de medische noodzaak, zijn te vinden bij Cole (1980), Winkel \& Statland (1984) en Rao e.a., (1982).

Het rantsoeneren van laboratoriumfaciliteiten wordt door Hardwick ea. (1981) bepleit. Hierbij zouden dure en complexe tests slechts in beperkte mate mogen worden aangevraagd (eventueel alleen op speciaal verzoek van bepaalde artsen). Dergelijke methodieken zouden mijns inziens meer als laatste redmiddel gebruikt dienen te worden. Het verdient de voorkeur om bij de evaluatie van testgebruik noch eenzijdig de nadruk te leggen op de effectenkant, zoals dit traditioneel door artsen is gedaan (baat het niet dan schaadt het niet), noch eenzijdig op de kostenkant zoals hier wordt voorgesteld.

Verderop in het boek worden methodologieën besproken, waarmee een meer evenwichtige evaluatie kan worden uitgewoerd, waarbij zowel kosten als effecten een rol spelen.

\subsection{CONCLUSIE}

Met name in de zeventiger jaren is er sprake van een explosieve groei in de laboratoriumproductie. Deze groei is mede onder invloed van de wijziging in de linanciering van ziekenhuizen sterk afgenomen. Daarmee lijkt de noodzaak voor een kritische beoordeling van het laboratoriumgebruik afgenomen te zijn ${ }_{\text {. }}$ ij nadere bestudering blijkt nog een groot aantal problemen te resteren. Zo is het nog steeds de vraag in welke delen van het laboratorium er sprake is van overgebruik of ondergebruik van tests.

De gevolgen van de automatisering zijn groot geweest. Automatisering van het laboratorium heeft geleid tot een daling van de productiekosten per eenheid, maar tevens de vraagontwikkeling vergemakkelijkt.

In sterk geautomatiseerde laboratoria kan de arts relatief goedkoop voorzien worden van grote hoeveelheden informatie. Een probleem hierbij is wellicht dat belangrijke stukken informatie minder opvallen. Voor de oplossing van dit probleem kan gebruik gemaakt worden van de computer die herinneringen samenstelt (McDonald, 1976) maar ook van interpretaties van testuitslagen die door computers worden opgesteld (McConnel e.a., 1979).

Verdere ontwikkelingen op dit terrein zullen nodig zijn om de laboratoriuminformatie tot een nuttig onderdeel van de klinische besluitvorming te maken. 
Aan de basis van een meer rationeel gebruik van het laboratorium staat een verhoogde kennis yan de kostenstructuur van de laboratoriumproductie. Kennis omtrent de kosten kan aangewend worden bij de interne budgettering, maar ook voor externe bedrijfswergelijkingen. Centralisatie van de laboratoriumproductie in regionaal verband of het werken in samenwerkingsverbanden zijn ontwikkelingen, die niet alleen voort dienen te komen uit de technologische ontwikkelingen en economische randwoorwaarden. Deze ontwikkelingen dienen vooral afgestemd te worden op de behoefte aan informatie. Het laboratorium dient gezien te worden als een onderdeel van deze medische dienstverlening. De informatie die het laboratorium levert zal zo dicht mogelijk de werkelijke behoefte aan informatie bij. de arts moeten benaderen. Maatregelen die vanuit het laboratorium genomen kunnen worden om de vraag naar tests in te perken, zouden dan ook meer gericht moeten zijn op het bevorderen van een rationeel testgebruik dan op het ruwweg opwerpen van drempels voor de arts.

Tenslotte, sinds de invoering van de interne budgettering zijn er zodanige prikkels voor efficiency-verbetering aanwezig dat commercialisatie van laboratoria vanuit dit oogpunt niet noodzakelijk is. Bovendien lijkt commercialisatie verder weg te voeren van het afstemmen van het aanbod op de vraag naar laboratoriuminformatie. 


\subsection{INLEIDING}

Over de rol van de arts in relatie tot de kosten van gezondheidszorg is reeds veel geschreven. De arts wordt steeds nadrukkelijker geïlentificeerd als degene die bepaalt welke zorg en hoeveel ervan verleend dient te worden. Meer dan $75 \%$ van alle kosten van gezondheidszorg worden door artsen geïnitieerd (Somers \& Somers, 1977). Nader onderzoek naar het aanvraaggedrag van artsen zou alleen op grond hiervan al een hoge prioriteit moeten hebben. In dit hoofdstuk wordt de aandacht gevestigd op de rol van de arts, waarbij enerzijds die factoren besproken worden die aangemerkt kunnen worden als medeveroorzakers van de kostenexplosie en waarbij anderzijds mogelijke strategieën worden aangegeven, die gevolgd kunnen worden om de vraag naar tests te beheersen.

Met de toename van beschikbare diagnostische middelen lijkt de onzekerheid ten opzichte van in te zetten hulpmiddelen meer dan evenredig toegenomen te zijn. Waren er in 1950 minder dan 100 laboratoriumtests beschikbaar voor artsen, in de tachtiger jaren was het aantal gegroeid tot boven de 800 (Grossman, 1983). Er worden momenteel dan ook veel hogere eisen gesteld aan selectief vermogen van de arts ten opzichte van diagnostische hulpmiddelen. Naast de explosie in beschikbare diagnostische en therapeutische mogelijkheden is de kennis omtrent de pathofysiologie sterk toegenomen. Daarnaast zijn er nog enkele ontwikkelingen welke ertoe hebben bijgedragen dat de positie van de arts gecompliceerder is geworden bij het selecteren van tests. In de eerste plaats zijn er veranderingen opgetreden in het ziektepatroon van de westers georiënteerde samenlevingen, waarbij de grote invloed van met ouderdom samenhangende ziekten opvalt (chronische degeneratieve ziekten). De psychische en sociale componenten in de ziektebeleving zijn bovendien belangrijker geworden. Een zuiver somatische diagnose is vaak onvoldoende om de behandeling op te baseren (Wright \& MacAdam, 1982). Dit alles impliceert dat er ook een grotere mate van onzekerheid is ontstaan ten aanzien van het gebruik van tests.

Naast de hierboven geschetste ontwikkelingen lijkt de arts onderhevig aan nog een tweetal factoren, die de praktijkvoering er zeker niet gemakkelijker op hebben gemakkt. De arts wordt in zijn dagelijkse praktijk steeds meer geconfronteerd met de beperking van beschikbare financiële middelen binnen de gezondheidszorg. Naast de effectiviteit worden nu ook de financięle gevolgen van de beslissingen steeds meer tot de verantwoordelijkheid van de arts gerekend.

Een tweede factor heeft betrëkking op de rol van de patiènt. De toegenomen mondigheid; leidt ertoe dat artsen vaker te maken krijgen met advocaten, die namens de consument verhaal komen halen voor vermeende fouten. In diagnostische situaties kan dit gemakkelijk leiden tot overgebruik van tests. Door sommigen wordt dit als een belangrijke mede-oorzalk van de stijgende kosten van het laboratorium aangemerkt (Bennington, 1981). Daarnaast heeft de toegenomen kennis over medische aangelegenheden tot gevolg dat een groter beroep gedaan wordt op de gezondheidszorg om vermeende ziektes uit te sluiten. 
Zolang er onder artsen geen consensus bestaat ower wat onder een optimaal gebruik van het laboratorium verstaan dient te worden, is niet duidelijk of het huidige gebruik een situatie vertegenwoordigt van overgebruik dan wel van ondergebruik. Bij het bestuderen van de literatuur op dit punt komt men het meest de opvatting tegen dat er sprake is van overgebruik. Zo beweert Reuben (1984) dat er sprake is van overgebruik met betrekking tot diagnostische tests, omdat de ontwikkelingen op therapeutisch gebied achter zijn gebleven op de diagnostische mogelijkheden. Een meer genuanceerd standpunt wordt ingenomen door bijvoorbeeld Wheeler e.a. (1977), $\mathrm{Zij}$ toonden middels een case-study aan dat er zowel sprake kan zijn van over-als ondergebruik. Overgebruilk was het gevolg van het onvermogen bij artsen om abnormale testuitslagen kritisch te beoordelen, terwijl ondergebruik het gevolg was van het niet adequaat vervolgen van abnormale testuitslagen.

Binnen de tests die worden aangeduid met overgebruik kan nog nader onderscheid gemaakt worden tussen overtollig en onjuist gebruik (De Vries, 1988). Tests worden door De Vries overtollig genoemd indien ze geen extra informatie opleveren. Onjuiste tests zijn die tests die in geen enkele relatie staan tot de eventueel te stellen diagnose. Deze laatste definitie is echter niet zonder meer toepasbaar op monitoring tests. Bovendien zijn er ook in de diagnostische fase tests die geen enkele relatie hebben met de te stellen diagnose, bijvoorbeeld tests die bedoeld zijn ter uitsluiting van hypothesen.

Het verzamelen van overtollige informatie, d.w.z. die informatie, die niet gebruikt wordt om de beslissing mede op te baseren, is overigens een wijd verspreid fenomeen binnen organisaties (Feldman \& March, 1981). Het treedt onder andere op doordat veelal de informatieverzameling organisatorisch gescheiden is van de informatiebenutting. De positie van het laboratorium is wellicht een klassiek voorbeeld van deze situatie.

In navolgende hoofdstukken zal een nadere invulling gegeven worden aan het begrip "optimaal" testgebruik. In dit hoofdstuk zal meer de nadruk gelegd worden op de grote verschillen tussen de artsen onderling wat betreft het gebruik van laboratoriumtests (par. 3.2), waarna achtereenvolgens dieper ingegaan wordt op deze verschillen, verschillen welke liggen op het persoonlijke (individuele) vlak (par. 3.3) en verschillen welke liggen op het institutionele vlak (par. 3.4).

In het tweede gedeelte van dit hoofdstuk wordt de effectiviteit van beheersingsstrategieèn beoordeeld aan de hand van de resultaten van empirische onderzoeken.

\subsection{VARIATIE IN AANVRAAGGEDRAG}

Er bestaat een aanzienlijke hoeveelheid bewijsmateriaal die aantoont dat er grote verschillen bestaan in aanvraaggedrag van artsen (Connelly \& Steele, 1980; Schroeder, 1980). In de beginjaren zeventig, met het stijgen van de kosten en het toenemend besef dat groei in testgebruik niet zonder meer synoniem is met een betere zorgverlening, verschenen ook steeds meer studies over het gebruik van laboratoriumtests door artsen (Griner, 1978).

Daarbij is er sprake van een veranderende houding van de kant van het management, maar ook langzamerhand van de kant van de professie zelf. Men zou kunnen stellen dat het traditioneel zo was dat artsen, die minder tests aanvroegen dan collega's, zich 
als het ware moesten verantwoorden voor "ondergebruik". We zien momenteel een verschuiving in de zin dat artsen die veel aanvragen zich moeten gaan verantwoorden tegenover hun collega's. De ratio is dat meer gebruik in ieder geval leidt tot inzet van schaarse middelen, waarbij de opbrengsten vooralsnog onduidelijk kumnen zijn. In een situatie waarbij deze schaarste zichtbaar is, bijvoorbeeld in een gebudgetteerde omgeving, zal de arts veel eerder ter verantwoording kunnen worden geroepen door het management, maar ook eventueel door collega's.

Een probleem hierbij is dat er vrijwel geen outcome-studies zijn verricht naar de effecten van het testgebruik, diw $z$ onderzoek naar de gezondheidseffecten bij patienten. Enkele onderzoeken trachten een relatie te leggen via proceskenmerken van het medisch handelen (Stilwell e.a., 1980).

In een onderzoek van Daniëls \& Schroeder (1977) is het aanvraaggedrag bijwoorbeeld gerelateerd aan een tweetal productiviteitskenmerken. Bij de eerste methode is het aantal behandelde patiënten per uur als indicator genomen en bij de tweede methode is een inschatting van het hoofd van de betreffende afdeling tot norm verheven.

In dit onderzoek is geen verband aangetoond tussen het gebruik van het laboratorium enerzijds en de beide productiviteitsmetingen aan de andere kant, hetgeen de onderzoekers doet concluderen dat de artsen, die mér laboratoriumtests aanvroegen, niet beter zijn, maar wel duurder. Met een dergelijke uitspraak worden artsen, die relatief veel tests aanvragen, in een positie gebracht, waarbij zij moeten bewijzen dat mér ook beter is.

Werman e.a. (1980) vinden in hun studie naar de reden van testaanvragen hoge percentages "zinvolle" tests. Bij tweederde van alle aanvragen is er sprake van een actie. Het begrip "actie" is echter zeer ruim omschreven. Een groot probleem bij deze studie is echter dat aan de artsen zelf gevraagd wordt aan te geven tot welke gevolgen de testuitslag leidde. De resultaten van deze studie wijzen dan ook eerder op het grote gelloof dat artsen hechten aan laboratoriuminformatie dan op de praktische waarde ervan.

De verschillen in aanvraaggedrag kunnen gigantisch zijn (Linn e.a., 1984). In een studie naar het aanvraaggedrag van tests wordt een spreiding in aangevraagde tests aangetroffen, waarbij sommige artsen zeventien keer zoveel tests aanvragen dan anderen. Artsen, welke geneigd zijn veel tests te gebruiken, schrijven tevens ook veel geneesmiddelen voor, al is de variatie met betrekking tot het woorschrijven wan geneesmiddelen geringer (Schroeder e.a., 1973). Deze overeenstemming duidt erop dat er sprake is wan een individuele component bij het gebruik van lichte technologie (zie ook par. 3.3.2).

Verschillen in aanvraaggedrag die in dwarsdoorsnede onderzoeken herhaaldelijk zijn aangetoond lijken over de tijd gezien constant te blijven (Freeborn e.a., 1972). Artsen die meer gebruiken in het ene jaar bleken ook in andere jaren veel tests te gebruiken, hetgeen opnieuw aantoont dat er sprake is van een persoonlijke factor.

Ook de geografische verschillen zijn onderwerp van studie geweest (Barth e.a., 1975). Uit deze studie blijkt dat het gemak waarmee artsen over tests kunnen beschikken en de nabijheid van het laboratorium inderdaad een rol spelen.

In de navolgende paragraaf wordt nader ingegaan op deze factoren waarbij achtereenvolgens individuele factoren en institutionele factoren worden besproken. 


\subsection{PERSOONSGEBONDEN VARIATIE}

\subsubsection{Leeftijd}

In het algemeen maken oudere artsen minder gebruik van diagnostische tests dan hun jongere collega's (Freeborn e.a, 1972). De factor leeftijd verwijst waarschijnlijk naar een onderliggende oorzaak van verschillen in testgebruik, namelijk het aantal ervaringsjaren. In hoofdstuk 1 is reeds aangegeven dat ervaren artsen op een andere wijze diagnostiseren dan artsen met minder ervaring. Als verklaring voor dit verschil kunnen een tweetal hypothesen worden aangedragen. In de eerste plaats hebben oudere artsen hun opleiding genoten in een tijd waarin nog niet zoveel diagnostische tests beschikbaar waren. Op grond daarvan hebben ze wellicht geleerd meer te vertrouwen op bijvoorbeeld het lichamelijk onderzoek. In dit geval ligt het voor de hand te veronderstellen dat ervaren artsen vooral minder gebruik maken van de nieuwe tests, waarvoor overigens aanwijzingen blijken te bestaan (Grossman, 1983).

In de tweede plaats kan het zijn dat oudere artsen op grond van hun ervaring (de zgn. klinische blik) beter in staat zijn om de gezondheidstoestand van de patiënt in te schatten of denken dat ze dat beter kunnen. In beide gevallen zullen ze minder behoefte hebben aan diagnostische tests dan hun jongere collega's. Oudere artsen blijken inderdaad meer dan jongere artsen te vertrouwen op de informatie verkregen uit anamnese en lichamelijk onderzoek (Barth e.a., 1975).

Voor het formuleren van beleid is het belangrijk exact te weten welke hypothese juist is.

In het eerste geval zou er well eens sprake kunnen zijn van een ondergebruik wan nieuwe technologie door ervaren artsen, terwijl in het tweede geval eerder sprake is van een overgebruik door jonge artsen. Een mogelijkheid om op dit punt beleid te voeren is gelegen in het verbeteren van de opleiding van artsen; de medische opleiding voor aanstaande artsen en de nascholing voor de artsen in de praktijk. Daarbij dient de arts meer te leren vertrouwen op gegevens uit anamnese en/of lichamelijk onderzoek en te leren leven met een bepaalde mate van onzekerheid, een element dat inherent is aan de medische praktijkvoering (zie verder par. 3.4).

\subsubsection{Rlsicogedrag}

Een tweede persoonskenmerk is het risicogedrag van de arts. Medisch handelen gaat per definitie gepaard met risico's. Nu zullen artsen verschillen in het vermogen om kansen te schatten, maar zelfs als zij de kansen op bepaalde uitkomsten even hoog schatten zullen zij verschillend kunnen handelen op grond van hun risicogeneigdheid. De meeste artsen zullen geneigd zijn risico's te mijden, d.w.z. zij zullen niet handelen volgens het criterium dat de verwachte opbrengst maximaliseert voor grote aantallen patiënten. Veelal zullen zij geneigd zijn het maximale verlies aan gezondheid voor de individuele patiënt zo gering mogelijk te houden. Deze houding staat bekend als risicomijdend gedrag en de strategie als minimax-least-loss strategie. Een risiconeutraal persoon handelt volgens een criterium, waarbij de verwachtingswaarde als uitgangspunt wordt genomen. In besliskundige analyses dient met de risicogeneigdheid van de beslisser rekening gehouden te worden.

Risicomijdend gedrag leidt in diagnostische situaties tot mérer gebruik van tests. Indien er een scala van behandelalternatieven beschilkbaar is, kan de arts kiezen voor een 
behandelstrategie waaraan weinig risico's zijn verbonden, In dat geval wordt het probleem van onzekerheid ten aanzien van de gezondheidstoestand van de persoon (ziek of niet-ziek) opgelost door de eventuele gezonde persoon niet op te zadelen met een al te zware ingreep. Aan de andere kant wordt dan wellicht volstaan met een minder effectieve therapie. Is deze mogelijkheid tot diversificeren niet aanwezig, dan zal de arts geneigd zijn de gevolgen wan onzekerheid te verminderen middels diagnostische procedures. Het ontbreken van alternatieve therapeutische strategieen wordt door Eeckhoudt (1985) als oorzaak van overmatig gebruik van diagnostisehe tests aangeduil.

Risicogedrag kan overigens worden ingegeven door uiteenlopende motieven. Zo kan de arts het oordeel van collega's vrezen bij cen gemiste diagnose, of bang zijn om door de patiënt aansprakelijk gesteld te worden wegens nalatigheid: $\mathrm{Er}$ is hierover vrijwel geen empirisch materiaal beschikbaar. Alworens beleidsmaatregelen te kunnen treffen zou bekend moeten zijn waardoor het risicogedrag van de artsen exact wordt bepaald.

\subsubsection{Kostenbewustzijn}

Uit de economische theorie stammen de vraagfuncties welke aangeven dat de vraag naar een bepaald goed daalt naarmate de prijs van het goed hoger is en omgekeerd. Indien deze vraagfunctie ook zou gelden in de laboratoriumsituatie dan zouden de artsen relatief minder dure tests aanvragen dan goedkope tests. In de oorspronkelijke theorie wordt ervan uitgegaan dat de vraag vermindert omdat de consument zelf de prijs van het betreffende goed moet betalen. In de gezondheidszorg initieert de arts; als agent voor de patiènt, de vraag en hij, noch de patiënt, zal enig direct financieel nadeel ondervinden van de geeffectueerde vraag. Een complicerende factor hierbij is overigens dat de arts/aanvrager doorgaans niet volledig geinformeerd is over de tarieven van tests, laat staan over de kosten. Dit betekent dat er aan twee voorwaarden voldaan moet zijn alvorens een strategie, die beoogt het kostenbewustzijn van artsen te verhogen, succesvol kan zijn. In de eerste plaats moet de arts geïnformeerd zijn over de kosten van de tests en in de tweede plaats moet dit verhoogd besef van de kosten een daling in onnodige aanvragen veroorzaken.

\section{Kennis over kosten}

Artsen zijn in verschillende mate in staat de werkelijk gehanteerde tarieven voor laboratoriumtests te schatten. Betrekkelijk weinig artsen hebben adequate kennis omtrent de actuele prijs. Skipper e.a.( 1976) vonden dat $\pm 1 / 3$ van de onderviraagde artsen een nauwkeurige schatting konden geven van kosten van tests. Accuraat werd een schatting genoemd die lag binnen een marge van $25 \%$ boven of beneden de actuele prijs. Iets meer dan $1 / 3$ gaf een te lage schatting en iets minder dan $1 / 3$ een te hoge schatting. Het resultaat van dit onderzoek is te beschouwen als een gemiddeld beeld over de kennis van artsen met betrekking tot kosten. In sommige onderzoeken blijkt het percentage onderschatters nog iets groter te zijn (Dresnich, 1979), in andere onderzoeken blijkt het percentage juiste schatters groter te zijn (Long e.a., 1983).

\section{Prijselastlciteit}

Over de vraag of het ontbreken van kennis van de kosten bijdraagt aan een overgebruik van tests bestaat minder eenduidigheid. Bewijsmateriaal waaruit blijkt dat artsen minder 
tests aanvragen, indien ze zich bewust zijn van de hoogte van de tarieven, is afkomstig van Schroeder \& Showstack (1978) en Cunnings (1982). Robertson (1980) daarentegen maakt duidelijk dat het verhogen van het kostenbewustzijn met als doel het gebruik van tests te verlagen weinig effect sorteert.

Empirisch bewijsmateriaal over de invloed van kostenbewustzijn op de vraag naar tests wordt aangedragen door Long e.a. (1983). In de eerste plaats hebben zij onderzocht in hoeverre artsen $(n=59)$ in staat zijn de actuele prijs te schatten van 77 tests. De resultaten hiervan zijn vergelijkbaar met overige studies op dit terrein. Van de schattingen valt $42 \%$ binnen de marge van $25 \%$ afwijking naar boven en naar beneden. Zij construeerden vervolgens een schaal waarmee artsen als over- respectievelijk onderschatters kunnen worden getypeerd en onderzochten vervolgens het aanvraaggedrag van de drie groepen. De experimentele groep heeft informatie gekregen over de werkelijke prijzen van de tests, de controlegroep niet. Uit het onderzoek blijkt dat vooral de hogere prijzen worden onderschat terwijl de lagere prijzen worden overschat. Naarmate artsen de prijzen onderschatten gebruiken ze ook meer tests en omgekeerd. Bij afwezigheid van werkelijke kosten maken artsen gebruik van een geschatte prijs, die in feilte "correct" functioneert binnen de vraagfunctie. Artsen schatten deze prijzen verkeerd. Maar eenmaal geschat handelen ze wel rationeel door minder dure tests aan te vragen en meer goedkope.

Empirisch blijkt dat een verhoging van het kostenbewustzijn bij artsen kan leiden tot een geringer gebruik van diagnostische tests. Het lijkt erop dat het verhogen van het kostenbewustzijn bij artsen kan leiden tot een daling in het gebruik van tests. Er is echter ook aangetoond dat de invloed van de testkosten op het nemen van beslissingen niet groot is, met name in die gevallen waar de ernst van de ziekte groot is. Bovendien is het meeste onderzoek verricht binnen academische ziekenhuizen met name met betrekking tot artsen in opleiding. Weinig tot niets is bekend over hoe artsen elders met een verhoogd kosteninzicht omgaan. Vooralsnog moeten niet al te hoge verwachtingen gekoesterd worden ten aanzien van het effect van dergelijke strategieën, zeker niet indien ze geissoleerd worden ingevoerd.

\subsection{INSTITUUTSGEBONDEN FACTOREN}

De opleiding tot aris wordt gestart bij de aanvang van de medische studie, wordt gecontinueerd in de post-doctorale fase waar meer klinische ervaring wordt opgedaan en krijgt tenslotte een voorlopige bekroning in de opleiding tot huisarts of specialist. De kennis veroudert echter zeer snel en het is dus noodzakelijk dat de praktiserend arts aan allerlei bijscholingsactiviteiten blijft doen; die kunnen uiteenlopen van het bijhouden van de relevante literatuur, het bijwonen van congressen en colloquia, werkoverleg en allerlei vormen van medical audit.

Indien in hét aanvraaggedrag verschillen geconstateerd worden, kunnen deze verschillen in principe in alle stadia van de opleiding of bijscholing zijn ontstaan. In deze paragraaf zal ingegaan worden op de factoren welke behoren tot de directe omgeving van de arts, dat wil zeggen de instelling waarbinnen de arts zijn opleiding krijgt of waarbinnen hij functioneert.

Het is algemeen bekend dat in universiteitsklinieken meer diagnostische tests worden aangevraagd dan gemiddeld in andere ziekenhuizen. Hiervoor is een aantal verklaringen te geven. In de eerste plaats ligt het voor de hand te veronderstellen dat de 
gemiddelde patièntenpopulatie in universiteitsklinieken met grotere gezondheidsproblemen kampt dan in overige ziekenhuizen het geval is (Sol ea., 1985). Stefanu e.a. (1984) toonden aan dat er een grote correlatie is tussen de ernst van de ziekte en het aantal gebruikte tests. Als maatstaf van de ernst van de ziekte gebruikten zij een "index", ontleend aan de verpleegintensiteit ( 6 puntsschaal) In de awatste patientenklasse bleek het aantal aangevraagde tests driemal zo hoog te zijn als in de laagste klasse. Bij de vergelijking tussen academische ziekenlhuizen en algemene ziekenhuizen dient in principe gecorrigeerd te worden voor het verschil in "case mix" van patiênten.

Schroeder \& O'Leary (1977) zijn in staat geweest om het aanvraaggedrag van artsen in dit opzicht nader te bestuderen. $\mathrm{Zij}$ vergelijken de behandelingspatronen van patiënten in een universiteitskliniek met een zoveel mogelijk gelijkwaardige patiëntengroep in gewone ziekenhuizen. Het bijzondere van het onderzoek is, dat de artsen gedeeltelijk in de universiteitskliniek werken en gedeeltelijk in de gewone ziekenhuizen. Van alle geconstateerde verschillen heeft het grootste verschil betrekking op het aantal diagnostische tests ( 26 in de universiteitskliniek en 18 in het gewone ziekenhuis). Dit verschil alleen al verklaart de helft van alle geconstateerde kostenverschillen.

Uit dergelijke onderzoeken blijkt het belang van de omgeving waarin de arts functioneert. In een universiteitskliniek is blijkbaar een sterke prikkel aanwezig om tests aan te vragen. Dit komt voort uit een grondhouding van de professie om toch wooral niets over het hoofd te zien. Een dergelijke houding heeft een zekere logica omdat de consequenties van "het iets over het hoofd zien" meestal veel groter zijn dan "het ten onrechte aanvragen wan een overbodige diagnostische test" (zie verder hoofdstuk 6 en volgende). In universiteitsklinieken is een dergelijke attitude pregnanter aanwezig dan in gewone ziekenhuizen en het is juist daar dat de aankomende arts zijn eerste praktijkervaring opdoet.

Bovendien is er geen enkele incentive om de student te bewegen tot een restrictief aanvraagpatroon van diagnostische tests, integendeel de eventuele missers zullen sterk benadrukt worden. Wanneer de aldus opgeleide arts in de praktijk werkzaam is, is de geneigdheid tot overdiagnostiek een wezenlijk kemmerk geworden binnen zijn besluitwormingsproces.

Uit een onderzoek van Grivell e.a. (1981) blijkt dat er een relatic is tussen aanvraagpatroon en opleidingsgraad binnen een universiteitskliniek. De "interns" (medische studenten die het eerste jaar in de kliniek stage lopen), die 17\% van de full-time staf vormen, vragen $33 \%$ van het totaal aantal tests aan, terwijl aan de andere kant de medische specialisten die $35 \%$ van de totale staf uitmaken slechts $12 \%$ van de tests aanvragen.

Dergelijke verschillen kunnen te maken hebben met de interne taakverdeling binnen afdelingen, maar er zijn sterke aanwijzingen dat er ook sprake is van overgebruik (Boice \& McGregor, 1983). In een proef, die drie maanden heeft geduurd, wordt het aanvragen van diagnostische tests, tot dan toe voornamelijk een taak van "residents" (artsen in opleiding), in handen gelegd van de staf. Geconstateerd wordt dat er $15 \%$ tot $20 \%$ minder tests worden aangevraagd, overigens hoofdzakelijk met betrekking tot de goedkope routinematige tests. De potentiele kostenbesparing wordt door de auteurs echter hoger ingeschat, omdat in het betreffende ziekenhuis reeds een aantal jaren een programma heeft gelopen om artsen een kosten-effectief aanvraaggedrag aan te leren. 
Het ligt voor de hand te veronderstellen dat het gedrag van de superviserende arts en collega's mede bepalend is voor het aanvraaggedrag van de arts zelf. De betekenis van saciale druk wordt onder andere aangetoond door Freeborn e.a. (1972). Indien het hoofd van een afdeling veel tests aanvraagt dan is de kans groot dat ook de overige artsen veel tests aanvragen.

Ook Grivell e.a. (1981) toonden in hun onderzoek aan dat het belang van de institutionele factoren niet onderschat moet worden. De verschillen in aanvraaggedrag van artsen in opleiding zijn veel meer terug te voeren op verschillen met een institutioneel karakter (aard van het ziekenhuis, aanvraaggedrag supervisor) dan op eventuele verschillen in medische opleiding.

Pinault (1977) daarentegen trof bij een groep van 34 internisten wel verschillen aan naar opleidingsinstituut. Artsen, opgeleid in wetenschappelijk georiënteerde instellingen, vroegen minder tests aan. Echter, indien er sprake was van grote onzekerheid, vroegen ze méer tests aan dan hun collega's.

Dit geeft tevens het dilemma aan van kostenbeheersingsstrategieën op het terrein van het laboratoriumgebruik. Aan de ene kant is het van groot belang juist in de opleidingsfase aandacht te schenken aan kosten-effectiviteitsoverwegingen bij het aanvragen van tests, aan de andere kant valt te constateren dat de cenmaal opgeleide artsen snel de heersende gewoonten op het punt van testgebruik overnemen. De effectiviteit van de geisoleerde strategie "verbetering van de opleiding" wordt beperkt door de overheersende gedragscodes in de bestaande ziekenhuizen (Wong \& Lincoln, 1983). Het is wellicht dan ook effectiever te trachten consensus te bereiken over een bepaald testgebruik in een bepaald medisch probleemveld en dit vast te leggen in protocollen. Invoering van dergelijke protocollen in zowel de universiteitskliniek als in de gewone ziekenhuizen zouden de basis kunnen leggen voor een meer efficiënt en effectief laboratoriumgebruik.

\subsection{OPTIMALISATIE VAN AANVRAAGGEDRAG}

\subsubsection{Inleiding}

In het laatste gedeelte van dit hoofdstuk zal de aandacht uitgaan naar de mogelijkheden om het aanvraaggedrag van artsen te moduleren in de richting van een meer optimaal gedrag. Een probleem hierbij is dat artsen, vaak van mening zijn dat verschillen in praktijkvoering in wezen horen bij het medisch beroep en de professionele autonomie en dus niet verwerpelijk zijn (Sheldon, 1986). De animo tot verandering zal dan ook niet groot zijn bij dit deel van de medische beroepsgroep.

De veranderingsstrategieèn zijn in een tweetal clusters samen te vatten. Het eerste cluster van strategieèn sluit aan bij de opleiding van artsen waarbij specifieke aandacht wordt besteed aan de vorming tot basisarts en de praktische opleiding zoals die gestalte krijgt in de opleidingsziekenhuizen. Veel van de aangehaalde onderzoeken zijn afkomstig uit de Verenigde Staten waar na een bepaalde vooropleiding de "medical school" kan worden doorlopen. De praktijkervaring vindt daarna plaats in een universiteitsziekenhuis ("interns" en "residents") gedurende een per specialisme variërende tijdsduur.

Het tweede cluster van strategieën beoogt de arts tot een meer optimaal aanvraaggedrag te bewegen wanneer deze met beide benen midden in de praktijk staat. Een groot aantal mogelijkheden dient zich aan. Men kan de arts informeren over zijn 
eigen aanvraaggedrag ten opzichte van dat wan collega's (feedback strategie). Men kan allerlei vormen van medical audit activiteiten stimuleren, van retrospectief status onderzoek (chart review) tot het opstellen van protocollen. In de meer administratieve sfeer kan gedacht worden aan het anders inrichten van het aanvraagformulier of andere aanvraagprocedures in het leven roepen, waaraan in hoofdstuk 2 reeds mandacht is geschonken.

Ook zou men kunnen overwegen "goed" gedrag (financieel) te belonen en "slecht" gedrag (financieel) te straffen. Als laatste mogelijkheid bespreken we maatregelen in de sfeer van budgettering: het limiteren van het aantal aan te vragen tests per verpleegdag of per opgenomen patient is én van de mogelijkheden, maar beperkingen kunnen ook opgelegd worden door invoering van afdelingsbudgetten.

\subsubsection{Medische opleilding}

Deze opvoedkundige strategie mikt in principe op een meer doelbewust inzetten van tests bij het oplossen van medische problemen. Daarbij wordt ervan uitgegaan dat verspilling van schaarse middelen tegengegaan kan worden, doordat artsen zich inzicht verschaffen in de medische problematiek en met name in de beperkte rol die diagnostische tests kunnen spelen bij het oplossen van dergelijke problematiek. Het uitgangspunt hierbij is dat een kosten-effectief gebruik van tests een wenselijk gedrag is, dat zo vroeg mogelijk in de medische opleiding aangeleerd dient te worden. Het aanleren van dit gedrag zal gemakkelijker zijn naarmate er meer rationele argumenten in de opleiding kunnen worden gebruikt, hetgeen impliceert dat meer de nadruk zal dienen te liggen op de wijze van redeneren en minder op het doorgeven van ervaringsfeiten in de opleiding. Kassebaum (1985) verkondigt ten aanzien van dit punt "There is too much at stake to assume any longer that physicians will learn to use the laboratory precisely and economically as a result of largely trial and error experiences during training". Technieken afkomstig uit de medische besliskunde kunnen uitstekend gebruikt worden als hulpmiddelen in het onderwijs aan studenten. De beslisboom is uiterst geschikt om de structuur van een diagnostisch probleem te verhelderen en maakt duidelijk waar nadere explicitering van waarde-oordelen nodig is.

Indien men in de medische opleiding meer aandacht wil gaan besteden aan kosten-effectief testgebruik dan is een belangrijke vraag welk moment in de opleiding daartoe het meest geschikt is. Vroeg in de opleiding vertoont de student nog de grootste openheid ten aanzien van nieuwe aspecten. Hoe meer de student echter geconfronteerd wordt met de praktijk, des te meer zal hij doordrongen zijn van de noodzaak in het besliskundig proces ook de economische overweging een rol te laten spelen.

Er zijn verscheidene pogingen ondernomen om reeds in de eerste jaren van de medische opleiding de student een rationeel aanvraaggedrag aan te leren, waarbij ook de kosten van laboratoriumtests worden betrokken. Zo beschrijft Clarke (1981) een onderwijskundig experiment, dat tot doel had de student kennis bij te brengen omtrent de betekenis maar ook de beperking van laboratoriumdiagnostiek. Hierbij wordt het diagnostisch proces stap voor stap doorlopen, waarbij gebruik gemaakt wordt van simulatietechnieken. De student analyseert in eerste instantie het probleem en identificeert potentieel nuttige laboratoriumtests. $\mathrm{Na}$ het bestuderen van de tests in kwestie (leereffectl) volgt het besluit al of niet de betreffende tests aan te vragen en 
vervolgens onivangt de student de testuitslag. Tenslotte analyseert hij het oorspronkelijke patientprobleem in het licht van de verkregen additionele informatie.

De mogelijke effecten van experimenten op het terrein van de medische opleiding wordt duidelijk aan de hand van het navolgende experiment (Spiegel e.a., 1982). In het derde jaar van de medische opleiding is aan een gedeelte van de studenten een cursus Medische Besliskunde aangeboden. Vervolgens zijn acht medische probleemgevallen aan deze groep studenten voorgelegd en aan een groep studenten die de cursus niet gevolgd hebben. Gemeten is hoe goed de studenten in staat zijn om de diagnose te stellen en het daaropvolgende beleid uit te stippelen, waarbij als standaard gold de mening van een team van experts. Tevens is nagegaan op welke wijze, via welke tests, men tot de diagnose geraakt, zodat ook de kosten van diagnostiek kunnen worden bepaald. De experimentele groep scoort over het algemeen minstens zo goed als de controlegroep, maar deze eerste groep is duidelijk beter in staat om het optimale opnamebeleid in ziekenhuizen te bepalen en gebruikt daarvoor diagnostische tests meer in overeenstemming met de mening van experts dan bij de controlegroep het geval is. De gemiddelde rekening voor diagnostische tests bedraagt $\$ 921$ (standaarddeviatie 86) in de experimentele groep tegenover $\$ 1900$ in de controlegroep (standaarddeviatie 154). Ook uit dit onderzoek blijkt dat minder diagnostiek niet per definitie slechter behoeft te zijn, en het is nuttig dit in een vroeg stadium in de opleiding te constateren.

Een andere interventiestudie is verricht door Everett (1985) en heeft betrekking op de polikliniek. Het betreft hier een groep "residents", random verdeeld in een interventiegroep en een controlegroep. De interventiegroep heeft gedurende 5 maanden een opleiding gekregen in kosten-effectief laboratoriumgebruik waarbij vooral de theoretische aspecten de aandacht hebben gekregen maar waarbij tevens het aanvraaggedrag in de praktijk is geêvalueerd. De praktijk bestaat uit besprekingen van het aanvraaggedrag middels chart review technieken.

Het onderzoek toont aan dat training van "residents" in kosten-effectief handelen een, zij het tijdelijk, effect heeft op het testgebruik. De effecten zijn het grootst bij de klinisch chemische tests die tot doel hebben gegevens te verschaffen over het beloop van de ziekte (monitoring tests).

Overigens is ook in dit onderzoek een versterkend effect gesignaleerd, indien de "interns" welke veel tests aanvragen begeleid worden door artsen die ook veel tests aanvragen.

Eisenberg (1977) rapporteert ook over zijn ervaringen met een dergelijke interventie. Bij een bepaalde test, prothrombine, die gebruikt is bij opnamescreening constateert hij een afname in thet gebruik van $87 \%$ tot $55 \%$ van alle patiènten tijdens het experiment. Echter anderhalf jaar na afloop van het experiment is het gebruik weer terug op het oorspronkelijke niveau.

Hij concludeert derhalve dat voor het veranderen van het (aanvraag)gedrag van artsen meer nodig is dan een eenmalige opvoedkundige inspanning, hetgeen overigens een bekend fenomeen is in de psychologie (Sherman, 1973).

Dit "tijdelijke" effect van opvoedkundige benadering wordt ook geconstateerd door Rhyne \& Gehlbach (1979) en Schroeder e.a. (1984).

Vergelijkbare resultaten worden gevonden door Martin e.a (1980), Klein e.a. (1980) en Dixon \& Laszlo (1974). 
Waar in alle bovengenoemde onderzoeken korte termijneffecten worden geconstateerd blijkt uit de analyse van Griner (1978) dat langdurige inspanningen op dit terrein tot aanzienlijke besparingen kunnen leiden. Griner heeft de veranderingen in het laboratoriumgebruik in de periode $1970-1975$ bestudeerd en stelt vast dat verbetering in het medische onderwijs een van de oorzaken is van het feit dat het gebruik in het betreffende laboratorium niet is toegenomen, terwijl het gemiddelde gebruik in overige ziekenhuizen jaarlijks is gestegen met $\pm 14 \%$.

Wat valt te concluderen met betrekking tot de effectiviteit van de opvoedkundige strategie die als doel heeft optimaal aanvraaggedrag aan te leren gedurende de medische opleiding?

Eenmalige, op zich staande, pogingen om het aanvraaggedrag van artsen te veranderen, lijken op de korte termijn weliswaar effecten te hebben, maar met het verstrijken van de tijd verdwijnen deze effecten, meestal zelfs binnen een jaar. Daarbij lijkt een aantal kanttekeningen op zijn plaats.

Veel van de "tijdelijke" effecten zijn mogelijk toe te schrijven aan de autoriteit van de onderzoeker, die indien hij een persoon met aanzien is zijn aanvraaggedrag min of meer oplegt aan de proefpersonen (residents en interns). Indien dit effect optreedt zijn de resultaten niet zonder meer generaliseerbaar (Eisenberg \& Williams, 1981; Myers \& Schroeder, 1981).

Verder lijkt de omgeving waarbinnen de experimenten zich afspelen erg belangrijk. Staan de artsen welwillend dan wel afkerig tegenover een dergelijke experiment? Het is daarbij van belang te weten, dat specialisten met de meeste aanvragen tevens ook de geringste aandacht tonen voor kostenbeheersing (Grivell e.a., 1981).

Verbetering van onderwijsmethoden met betrekking tot kosten-effectief testgebruik heeft op zichzelf weinig effect of geen langdurig effect. De sociale, economische en professionele druk is in de praktijk te hoog. Meer actieve vormen, waarbij ook de senior artsen in het onderwijskundig proces worden betrokken, hebben een grotere kans van slagen (Everett e.a., 1983).

Eveneens is bekend dat gedragsverandering sneller is te bereiken indien goed gedrag beloond wordt of slecht gedrag gestraft, waarbij de eerste strategie overigens effectiever is (zie ook paragraaf 3.5 .4 .).

\subsubsection{Feedback}

De feedback-strategie gaat uit van de hypothese dat het informeren van artsen over hun aanvraaggedrag de variatie in hun aanvraaggedrag doet vermindleren. De hypothese hierbij is dat het signaleren van afwijkingen meer effect heeft op de artsen die boven het gemiddelde liggen dan op de artsen beneden het gemiddelde, zodat als totaal effect een verminderd gebruik resulteert.

Feedback wordt vaak gehanteerd in combinatie met audit-activiteiten teneinde de effectiviteit van de methode te verhogen. Het is bekend dat strategieën zuiver gericht op het beter informeren van artsen hun doel vaak missen, zeker indien dit doel is het veranderen van het gedrag. Een mogelijke oorzaak van dit falen is het feit dat het diffusieproces, zoals dit bijvoorbeeld geldt voor de verspreiding van technologieën, niet opgaat voor de verspreiding van kennis (Kanouse \& Jacoby, 1988). Om de effectiviteit te verhogen zou de informatie meer moeten aansluiten bij gedragsbepalende factoren. 
De artsen confronteren met de kostenaspecten van hun handelen is een bepaalde vorm wan feedback. Een andere mogelijkheid betreft het samenstellen van statistische overzichten om artsen te laten zien hoeveel tests zij aamvragen in wergelijking met hun collega's.

Hughes ea (1984) hebben een onderzoek verricht met betrekking tot de laboratoriumproductile in 25 ziekenhuizen.

De gemiddelde productie is min of meer als standaard gebruikt en de ziekenhuizen met een hoge productie zijn benaderd om eventueel overgebruik van tests te kunnen vaststellen. Alleen al het op deze wijze in kaart brengen wan de laboratoriumproductie en het vergelijken op ziekenhuisniveau heeft tot effect, dat binnen vijf van de zes ziekenhuizen, die als veelgebruikers zijn bestempeld, plannen zijn ontwikkeld om het laboratoriumgebruik terug te dringen.

Grivell e.a, (1981) hebben een onderzoek gedaan naar de invloed van het verstrekken van informatie aan artsen over hun eigen aanvraaggedrag. Iedere specialist heeft voor een vierweekse periode de samenvatting gekregen van zijn aanvraaggedrag met informatie over aantal patienten, aantal aanvragen, aantal abnormale testuitslagen en potentiele kosten, etc. Uit de evaluatie bleek dat een dergelijk programma niet leidde tot een significante reductie in het totalle mantal aangevraagde biochemische tests. In het cerste jaar na invoering, wordt de hoogste opbrengst verwacht maar ook dit kon niet worden bevestigd. Het wordt niet aannemelijk geacht dat het feit, dat er geen effect geconstateerd is, verklaard kan worden op grond van een kritische houding wan de aanvragers ten opzichte van het experiment. Over het algemeen reageren deze positief op de verstrekte informatie.

Berwick \& Coltin (1986) constateren in hun studie daarentegen een daling in testgebruik van $14,2 \%$ ten gevolge van een interventie, gebaseerd op feedback van kostengegevens. In dezelfde HMO-setting leidt een opvoedkundige interventie noch feedback, gebaseerd op abnormale testuitslagen, tot noemenswaardige effecten.

Een aantal van de reeds genoemde studies maakt ook gebruik van feedback elementen (Klein e.a., 1980; Lyle e.a., 1979). De meeste onderzoeken zijn uitgevoerd zonder controlegroep zodat de conclusies niet zonder meer te veralgemeniseren zijn.

Hoewel uit een aantal onderzoeken het tegendeel blijkt, lijkt een feedback strategie, indien deze geilsoleerd wordt ingevoerd, over het algemeen niet erg effectief te zijn. Feedback strategieen hoeven echter ook niet duur te zijn, zeker indien ze aansluiten op reeds bestaande administratieve procedures. Welke kostenbeheersingsstrategic men ook werkiest, men zal altijd over een inventarisatie willen beschikken van het huidige gebruik van tests, zodat dergelijke overzichten zonder al te veel extra inspanningen kunnen worden samengesteld en aan artsen beschikbaar gesteld.

In de bovenwermelde feedback strategie wordt aan artsen statistische informatie gegeven over aantallen of kosten van aangevraagde tests zonder in te gaan op het nut van de aangevraagde tests. In de navolgende strategieen wordt dat nut expliciet in de feedback strategie betrokken. Chart review is een methode waarbij retrospectief het aanvraagpatroon bestudeerd wordt aan de hand van patiëntendossiers, waarbij de reden wan aanvrag achteraf geevalueerd kan worden. Het probleem hierbij is dat patientendossiers vaak onvolledig ingevuld zijn. Martin e.a. (1980) toonden aan dat deze vorm van statusonderzoek een kosten-effectieve manier kan zijn om 
laboratoriumgebruik te reduceren. Tegenover de $\$ 15,000$ aan kosten voor het programma staan een geschatte 2 miljoen besparing op laboratoriumkosten in het betreffende ziekenhuis.

Rhyne \& Gehlbach (1979) hebben een chart review experiment uitgevoerd uit met betrekking tot een bepaalde groep van tests. Er is begonnen met een bespreking van patièntgegevens middels chart review en tezamen met de artsen zijn criteria voor het gebruik opgesteld. Gedurende de drie daaropvolgende maanden blijkt er een significante daling in het aantal aanvragen van de betreffende tests. Echter in het daaropvolgende kwartaal blijkt dit effect reeds verdwenen. De onderzoekers concluderen dat er andere factoren zijn die sterker zijn dan de impulsen, die uitgaan van deze rationele wijze van benaderen om het testgebruik omlaag te krijgen.

Indien de criteria voor gebruik voldoende geëxpliciteerd zijn, kan gebruik gemaakt worden van geautomatiseerde feedback systemen. Eisenberg e.a. (1977) hebben geëxperimenteerd met een geautomatiseerde feedback methodiek. $\mathrm{Zij}$ concluderen dat het systeem wel functioneert in de zin dat oneigenlijk gebruik wordt opgespoord, maar dat het tweede gedeelte van het experiment (de arts bewegen tot een ander gebruik) faalt. Als mogelijke oorzaken signaleren zij

- het gebrek aan incentives bij artsen om te komen tot efficiënter gebruik van tests;

het feit dat het experiment slechts betrekking heeft gehad op een enkele test (LDH), hetgeen mogelijkerwijs de motivatie van de arts om aan het experiment deel te nemen negatief heeft beilnvloed.

Het vooraf opstellen van expliciete criteria kan ook gebruikt worden voor de introductie van protocollaire geneeskunde. Bij het nemen van beslissingen in de praktijk kan de arts protocollen hanteren. Ook hier zijn weer zeer uiteenlopende resultaten te melden met betrekking tot het gebruik van tests. Doordat in protocollen vaak volledigheid wordt nagestreefd leidt invoering van protocollen vaak tot een toename in het gebruik van tests. Het tegenovergestelde effect is echter even goed denkbaar. Door het opvolgen van een aantal tamelijk conservatieve aanbevelingen omtrent aanvraaggedrag zouden aanzienlijke besparingen op laboratoriumkosten gerealiseerd kunnen worden op jaarbasis (Winkel \& Statland, 1984).

\subsubsection{Financiele prikkels en limitering}

Indien men wil bereiken dat er minder tests worden aangevraagd, kan dat op verschillende manieren geeffectueerd worden. $\mathrm{Zo}$ is het mogelijk om via interne budgettering een zodanige druk op de organisatie te creëren dat restrictief handelen noodzakelijk wordt. Hierop zal in hoofdstuk 9 worden ingegaan.

Op twee andere mogelijkheden zal hieronder nader worden ingegaan aan de hand van min of meer "klassieke" experimenten. Deze twee mogelijkheden zijn het stimuleren van goed gedrag middels financiële beloning en het min of meer limiteren van het aantal tests.

Bij de eerste mogelijkheid kan gebruik gemaakt worden van het belonen van gewenst gedrag of het bestraffen van ongewenst gedrag. 
Martin e.a. (1980) hebben een experiment uitgevoerd met onder andere als doel het aanvraaggedrag van co-assistenten (residents) te beünvloeden via positieve prikkels. $\mathrm{Er}$ zijn drie groepen gevorm, de controlegroep, die alleen op de hoogte gebracht is van het onderzoek, een tweede groep, die een financiêle beloning heeft ontvangen indien het gemiddeld antal aanvragen gedurende de onderzoeksperiode daalde (het bedrag, een paar honderd dollar per jaar, kon besteed worden voor de aanschaf van studieboeken); en cen derde groep waarbij op intensieve wijze statusonderzoek is gedaan.

Het blijkt dat de innanciele prikkel een daling van het gebruik tot gevolg heeft, maar het effect verdwijnt onmiddellijk wanneer de financiele prikkel niet meer wordt toegepast: Het mislukken van de poging wordt wellicht (mede) veroorzaakt door het feit dat de eventuelle beloning ook aan de andere onderzoeksgroep zou worden uitgereikt. Dit kan de mogelijke incentive-werking van de financiele beloning nadelig beinvloed hebben.

Het effect van statusonderzoek blijkt veel groter dan het effect van de financiele prikkel, maar belangrijker is, dat ook na de interventieperiode het aantal tests nog verder daalt. Overigens is er ook in de controlegroep, die slechts eén uur college heeft gevolgd, waarbij de bedoeling van het experiment uiteengezet is, een daling bereikt. Bijna iedere ingreep heeft een, zij het tijdelijk, effect, zo concluderen de onderzoekers.

Zijn de bovengenoemde strategieèn nog min of meer vrijblijvend in de zin, dat zij trachten de arts te interesseren in en te motiveren tot een meer optimaal gebruik van tests, de navolgende "limiterings"-strategie gaat uit van hardere dwangmaatregelen zoals het rigoureus beperken van het aantal aan te vragen tests.

Dixon \& Laszlo (1974) tonen in een experiment onder stafieden aan dat slechts een zeer gering gedeelte van klinisch chemische tests de behandeling wan de patient beïnvloedt. Als "bruikbare" laboratoriumbepalingen beschouwen zij tests die:

- medicatie tot gevolg hebben,

- leiden tot een terzake doende opmerking in het patientendossier,

- op juiste wijze worden herhaald of,

- indien de uitslag negatief is, leiden tot een opmerking dat bepaalde diagnoses in het vervolg worden uitgesloten.

Alle andere tests worden als nutteloos beschouwd. Bij het hanteren van deze afspraak bedroeg het aantal bruikbare tests slechts $5 \%$.

In de tweede fase van de studie wordt het totaal aantal aan te vragen tests gereduceerd tot acht per verpleegdag. Het aantal dat als bruikbaar wordt bestempeld stijgt nu tot $23 \%$. Het aantal abnormale testuitslagen blijkt een goede benadering te zijn voor de evaluatie van het diagnostisch proces, aangezien er een hoge correlatie is aangetoond met het aantal bruikbare tests. De onderzoekers concluderen, dat het aanvraaggedrag van artsen sterk verbeterd kan worden. Het aantal tests zou verminderd kunnen worden met $25 \%$ zonder verlies aan informatie. Met name indien zonder duidelijke opgave van redenen herhaaltests worden uitgevoerd na opnamescreening wordt geen additionele informatie verkregen. Deze tests zijn dan ook achterwege gelaten bij het restrictief beleid, hetgeen suggereert dat artsen cen bepaald idee hebben over wat zinvol is en wat niet. $\mathrm{Z}_{\mathrm{ij}}$ dienen een prikkel te krijgen om deze kennis in de praktijk toe te passen. Ook uit een onderzoek van Everett e.a. (1983) blijkt dat artsen, indien zij gedwongen worden tot het aanvragen van minder tests, met name bezuinigen op tests ten behoeve 
van opnamescreening en datamaast ook op monitoring tests, terwijl tests ten behoeve van diagnostiek worden ontzien. Het stat echter nog geenszins vast, dat deze handelwijze ook vanuit kosten-effectiviteitsovenwegingen de meest wenselijke is.

\subsection{SAMENVATTING EN CONCLUSHES}

Uit de grote variatie in gebruik van tests door artsen kan opgemaakt worden dat er een geringe mate van consensus bestaat over wat onder optimaal gebruik dient te worden verstaan. Nadere analyse van dit verschillend gebruik toont aan dat er sprake is van individuele verschillen zoals leeftijd, mate van risico-geneigdheid, kostenbewustzijn, maar ook van instituatsgebonden factoren zoals bijvoorbeeld de aard van het ziekenhuis. Een belangrijk gedeelte van de tests is niet werkelijk nodig voor een effectieve diagnose en behandeling van de patiënt. De marginale winst in kennis door middel van tests is in velle gevallen laag.

Gebruik van minder tests is overigens niet zonder meer synoniem met een meer efficiënte en effectieve gezondheidszorg. Wat woorkomen dient te worden is dat artsen hun aanvraaggedrag zo gaan wijzigen dat elders in het ziekenhuisgebeuren meer kosten ontstaan. Voorbeelden hiervan zijn: besparen op monitoring tests, zodal patiénten langer in het ziekenhuis moeten blijven; besparen op bepaalde screening tests c.q. tests ten behoeve van opnamescreening, zou een ander voorbeeld hiervan kunnen zijn.

Een verdere ontwikkeling van kosten-effectiviteitsanalyses, welke toegepast kunnen worden op het testgebruik, is gewenst teneinde prioriteiten te kunnem stellen met betrekking tot bovengenoemde functies van tests.

De arts vertolkt een sleutelrol bij het aanvragen van tests en is dus ook de sleutelfiguur voor het beperken van het aantal tests.

Strategieën om het aantal tests te beperken kunnen grofweg betrekking hebben op de medische opleiding of aangrijpen in de praktijksituatie.

Uit de aangehaalde onderzoeken kan de volgende algemene conclusie geformuleerd worden: De meeste strategieën om het aantal tests te verminderen worden gekenmerkt door een matige en/of een slechts kortdurende effectiviteit; indien deze geisoleerd worden toegepast. Meer effect hebben combinaties van strategieen, waarbij aan de ene kant aandacht besteed wordt aan het creëren van inzicht in effectief gebruik, waarbij artsen worden aangesproken op hun rationaliteit en aan de andere kant een prikkel wordt gehanteerd om deze inzichten in de praktijk toe te passen.

Meer specifiek kunnen de volgende conclusies worden getrokken.

Het samenstellen wan statistische en/of financiële overzichten over aanvraaggedrag per specialist is lang niet altijd een voldoende prikkel. Het botweg limiteren van het aantal aan te vragen tests heeft wel effect maar wordt door artsen te zeer ervaren als een. inbreuk op de vrijheid van medisch handelen, waarbij het gevaar niet denkbeeldig is dat ook op bruikbare tests wordt bezuinigd.

De roll van de medische opleiding met betrekking tot deze problematiek lijkt, in tegenstelling tot wat valk beweerd wordt, op korte termijn bescheiden.

De invloed van de latere praktijkomgeving is vele malen groter en het ligt dan ook voor de hand de medisch student kosten-effectief aanvraaggedrag aan te leren wanneer deze in de praktijksituatie is gearriveerd. In de doctoraalfase zou wel aandacht besteed 
moeten worden aan de principes van economisch handelen, waardoor de student zich de redeneertrant al eigen kan maken.

De nadruk dient echter te liggen op de vorming van de basisartsen in de klinische periode, wanneer min of meer zelfstandig beslissingen genomen moeten worden over in te zetten hulpmiddelen, en ongewenst gedrag gemakkelijker kan worden bijgestuurd. In deze fase zou een efficient en effectief aanvraaggedrag moeten worden aangeleerd, hetgeen het beste kan geschieden door de opleiders zelf. Dit impliceert dat het nog belangrijker is om de opleiders zo ver te krijgen dat ze kosten-effectief testgebruik een onderdeel van de opleiding maken. Het leren leven met een bepaalde mate van diagnostische onzekerheid is hierbij cen eerste stap (Reuben, 1984).

Om dergelijke strategieen in de praktijk van het medisch handelen effectief te doen zijn, is het, zoals bovengesteld, absoluut noodzakelijk aanvullende maatregelen te treffen die ervoor zorgen dat artsen ook daadwerkelijk geëngageerd raken met de kostenkant van het probleem. Voor de Nederlandse gezondheidszorg vormt de verdere uitwerking en toepassing van de principes van interne budgettering hiervoor een goede basis.

De invoering van budgettering maakt het steeds meer noodzakelijk dat artsen al hun handelen, dus ook aanvragen van diagnostiek, kritisch analyseren. Besliskundige technieken, eventueel leidend tot diagnostische protocollen, kunnen een krachtig hulpmiddel zijn tot stroomlijning van het aanvraaggedrag. Bij de totstandkoming van protocollen zou meer dan tot nu toe het geval is rekening gehouden moeten worden met kosten-effectiviteitsowerwegingen. 


\subsection{INLEIDING}

In dit hoofdstuk worden tests beoordeeld op de mate waarin ze onzekerheid kunnen reduceren met betrekking tot het al of niet voorkomen van bepaalde ziekten. Daartoe wordt uitgegaan van een vereenvoudigd model. In de loop van de volgende hoofusstukken zullen meer complexe situaties worden bekeken die meer resle situaties benaderen waarmee artsen in hun dagelijkse praktijk worden geconfronteerd. In de meest eenvoudige testsituatie is er sprake van een dichotomie zowel wat betreft de testuitslag als ook wat betreft de manifestatie van de ziekte. Een dergelijke situatie is weer te geven in een $2 \times 2$ tabel. Aan de hand van een $2 \times 2$ tabel kan een aantal criteria worden besproken met behulp waarvan het diagnostisch proces kan worden geevvalueerd (par. 4.2.1). Verder worden enkele begrippen bepaald, horende bij de $2 \times 2$ tabel, die ook in meer ingewikkelde evaluatiesituaties een rol spelen (par. 4.2 .2 en 4.2.3). Vervolgens wordt in par. 4.3 de aanname losgelaten van de dichotome testuitslag. Testuitslagen mogen nu plaatswinden op een bepaald continuüm waarbij een indeling in klassen wordt gehanteerd (discrete verdeling) (par. 4.3.1). Een tweede lijn volgens welke het diagnostisch proces kan worden beoordeeld is het bepalen van de mate waarin de onzekerheid wordt gereduceerd (par. 4.4 en 4.5 ).

\subsection{DICHOTOME TEST EN ZIEKTE}

Een test kan worden opgevat als een bericht, waarbij het bericht een al of niet correcte uitspraak doet over de werkelijkheid. Gaan we uit van het algemene informatieschema ontleend aan Shannon \& Weaver (1972) dan wordt een bericht, afkomstig uit een bron, getransformeerd tot een signaal dat wordt uitgezonden. Het signaal wordt op zijn beurt weer ontvangen en getransformeerd tot een bericht (of informatie) met een bepaalde bestemming. Bij een test kan dit schema als volgt geconcretiseerd worden. De patiënt (bron van de informatie) heeft symptomen of verschijnselen op grond waarvan de arts besluit tot het aanvragen van een test. De testuitslag kan beschouwd worden als een bericht dat informatie bevat over het al of niet aanwezig zijn van de ziekte. Bij visueel te interpreteren tests zal er een waardering uitgesproken moeten worden; bijwoorbeeld normaal (geen bijzonderheden) of abnormaal (afwijkingen). De arts, als agent voor de patiènt, ontwangt en decodeert het bericht en kan vervolgens op basis van de testuitslag besluiten tot verdere acties.

$\mathrm{De}$ rol van de arts is hierbiji een heel bijzondere en dient nader uitgewerkt te worden. In hoofdstuk 1 is reeds globaal ingegaan op de specifieke problemen die zich voordoen op het terrein van de diagnostiek en in het voorgaande hoofdstuk is het aanvraaggedrag van artsen nader geanalyseerd. De arts beperkt zich zeker niet tot het decoderen van het bericht. Hij zal het bericht mader moeten interpreteren (gegevens moeten omzetten tot informatie) en vervolgens beslissingen moeten nemen. Hieronder zal nader ingegaan worden op de besliskundige technieken, die als hulp gebruikt kunnen worden bij thet nemen van deze besilssingen. Ook zonder de genoemde interpretatieproblematiek is het in de praktijk vaak zo dat datgene wat de testuitslag aangeeft niet volledig overeenstemt met de werkelijkheid. Voordat hierop dieper ingaan wordt zal eerst een beperking worden aangebracht. Verondersteld wordt in eerste 
instantie dat zowel de testuitslag als de ziektemanifestatie slechts twee toestanden kennen: Een persoon kan ziek (D+) of gezond zijn (D-) en de testuitslag kan "positief" $(\mathrm{T}+)$ ofwel "negatief" ( $\mathrm{T}$-) luiden. In de praktijk zal aan deze veronderstelling niet altijd voldaan zijn. Het onderscheid tussen ziek en niet-ziek kan vaag zijn, maar ook een testuitslag kan twijfelachtig zijn. Er is in dat geval meer sprake van een $3 \times 3$ tabel (Sappenfield e.a., 1981).

Indien de testuitslag positief is dan kán in werkelijkheid de ziekte aanwezig zijn (terecht positief of TP), maar dat behoeft niet het geval te zijn (fout-positieve testuitslag of FP). Omgekeerd kan, indien een testuitslag negatief, de ziekte bij de patiënt daadwerkelijk afwezig zijn (TN) of kan de ziekte toch aanwezig zijn (FN). In het jargon van de signaaldetectie wordt de TP aangeduid met "hit" en de TN met "correct rejection". De FP is een "false alarme" en de FN is een "miss". In de volgende $2 \times 2$ tabel zijn de vier mogelijkheden weergegeven.

Tabel 4.1. 2x2-tabel

\begin{tabular}{|c|c|c|c|}
\hline & zlekte aanwezig & ziekte af wezig & \\
\hline $\begin{array}{l}\text { Posftieve } \\
\text { testuitslag }\end{array}$ & $\begin{array}{c}\text { terecht positief } \\
\text { TP }\end{array}$ & $\begin{array}{c}\text { fout positief } \\
\text { FP }\end{array}$ & $T+$ \\
\hline $\begin{array}{l}\text { Negatleve } \\
\text { testuit tslag }\end{array}$ & $\begin{array}{c}\text { fout negatief } \\
\text { FN }\end{array}$ & $\begin{array}{c}\text { terecht negatiof } \\
\text { TN }\end{array}$ & $T=$ \\
\hline
\end{tabular}

Het totaal van de vier groepen vormt samen de populatie $\mathbb{N}$, die bestaat uit twee subgroepen: de zieken ( $D+$ ), bestaande uit TP en FN en de niet-zieken (D-), bestaande uit FP en TN. De totale groep kan ook opgesplitst worden in de subgroepen $\mathrm{T}+$ en $\mathrm{T}$-.

De prevalentie van de ziekte in de populatie $\mathrm{N}$ is het aantal zieken op een bepaald moment gedeeld door de totale populatie.

$$
P=P(D+)=(D+) / N
$$

De prevalentie bevat informatie over het al of niet aanwezig zijn van de ziekte in de bevolking. Nu worden tests meestal niet toegepast op a selecte steekproeven uit de bevolking maar op subgroepen welke zich onderscheiden door specifieke kenmerken waardoor de kans op de ziekte groter is dan in de gehele bevolking. De dan geldende kansen worden aangeduid met a priori kansen op de ziekte, d.w.z. de kans op de ziekte bij de betreffende persoon vóórdat de betreffende test wordt uitgevoerd. De mate waarin de test erin slaagt om uit de totale groep van zieken $(D+)$ personen terecht als ziek te kenmerken wordt de gevoeligheid of de sensitiviteit (Se) van de test genoemd.

$$
\mathrm{Se}=\mathrm{P}(\mathrm{T}+\mid \mathrm{D}+)=\mathrm{TP} /(\mathrm{D}+)
$$


De mate waarin de test erin slaagt om niet-zieke personen terecht als niet ziek te kenmerken wordt de specificiteit (Sp) van de test genoemd.

$$
\mathrm{Sp}=\mathrm{P}(\mathrm{T}-\mid \mathrm{D}-)=\mathrm{TN} /(\mathrm{D}-)
$$

De begrippen sensitiviteit en specificiteit blijken een relatie te vertonen met de terminologie "fout van de eerste soort" en "fout van de tweede soort". Deze fouten worden ook aangeduid met resp. $\alpha$ - en $B$-fout. Er bestaat echter geen overeenstemming over de exacte relaties. Zo gaan bijvoorbeeld Sondik (1982) en Schweitzer (1974) ervan uit dat de fout wan de eerste soort gelijk is aan (1-Sp), terwijl anderzijds Barnoon \& Wolfe (1972), Miller (1981) en Sturmans (1986) de fout van de eerste soort definieren als (1-Se). De verschillen blijken bij nader inzien voort te komen uit de verschillende praktijksituaties, waaraan de diverse auteurs refereren. In een screeningssituatie is de meest logische benadering om als mulhypothese $\left(\mathrm{H}_{0}\right)$ te stellen dat de persoon in kwestie gezond is en de alternatieve hypothese $\left(\mathrm{H}_{1}\right)$ wordt dan vanzelfsprekend dat de persoon ziek is. In de klinische situatie ligt het daarentegen meer woor de hand om als $\mathrm{H}_{0}$ te veronderstellen dat de persoon in kwestie ziek is . De fout van de eerste soort is in beide gevallen gelijk aan de kans dat de nulhypothese ten onrechte wordt verworpen. In een screeningssituatie betekent dit dat een fout-positieve melding tot fout van de eerste soort wordt gerekend (1-Sp). In de kliniek wordt ervan uitgegaan dat de persoon ziek is totdat het tegendeel is bewezen. Het "missen" van een ziektegeval wordt daar zwaarder aangerekend dan het ten onrechte stellen van een diagnose bij een gezond persoon.

Aangezien in dit boek aandacht wordt besteed zowel aan screening als aan de meer klinische praktijksituaties is hantering van de begrippen "fout van de eerste en tweede soort" zeer verwarrend en zijn de begrippen sensitiviteit en specificiteit eénduidig in dichotome situaties. Een bijkomend voordeel is dat artsen waarschijnlijk meer vertrouwd zijn met deze laatste begrippen.

De sensitiviteit en de specificiteit worden geacht kenmerken van de test te zijn, die gelden bij iedere toepassing van dezelfde test. Er komen overigens steeds meer aanwijzingen dat men hier niet zonder meer vanuit kan gaan (Harris, 1981) (zie ook hoofdstuk 9).

Kan op grond van de informatie van een $2 \times 2$ tabel geconcludeerd worden of er sprake is van een "goede" dan wel een "slechte" test? We benaderen deze vraagstelling in eerste instantie vanuit de vooronderstelling dat het diagnostisch proces een op zichzelf staand geheel is, los van eventuele therapeutische consequenties. Wat een test doet c.q. moet doen, is onderscheid maken tussen zieken (D+) en niet-zieken (D-), d.w:z. de test moet een zo hoog mogelijk discriminerend vermogen hebben. Om het discriminerende vermogen van een test te kunnen beoordelen zijn diverse maatstaven gebruikt (Swets \& Pickett, 1982).

Een mogelijkheid is om uit te gaan van de sensitiviteit en de specificiteit van de test. Duidelijk is de situatie wanneer een bepaalde test zowel een grotere sensitiviteit als een grotere specificiteit heeft dan de alternatieve test, maar wat te besluiten indien een grotere sensitiviteit gepaard gaat met een lagere specificiteit? In paragraaf $4.3 \mathrm{zal}$ hier nader op ingegaan worden. Hieronder zal eerst de invloed van de a priori kans op de waarde van een test nagegaan worden. 


\subsubsection{Predictleve waarde}

Door toepassing wan de test verandert de a priori kans op de ziekte in de totale populatie in een a posteriori kans op ziekte. Dit wordt het predictieve waarde-model genoemd (Galen \& Gambino, 1975). Er bestaan diverse methoden om de a posteriori kansen te bepalen (Weinstein e.a., 1980). De meest eenwoudige methodiek is gebaseerd op de $2 \times 2$ tabel. Indien de prevalentie van ziekte, de sensitiviteit en de specificiteit van de test bekend zijn, heeft de $2 \times 2$ tabel nul vrijheidsgraden m.a.w. de vier velden zijn te bepallen met behulp wan deze drie kenmerken. Dit impliceert dat op basis van deze drie kenmerken in de groep met positieve testuitslagen $(T+)$ te bepalen is welk gedeelte terecht positief (TP) en welk gedeelte fout positief (FP) is.

De regel van Bayes legt deze rekenprocedure als volgt vast:

De kans op ziekte gegeven een positieve testuitslag is gelijk aan: $P(D+\mid T+)$. Uit de $2 \times 2$ tabel is af te leiden dat deze kans gelijk is aan TP/(TP $+F P)$. Aangezien de TP en FP te bepalen zijn uit de sensitiviteit, de specificiteit en de prevalentie is ook deze voorwaardelijke kans te bepalen:

$$
P(D+\mid T+)=\frac{P(T+\mid D+) \cdot P(D+)}{P(T+\mid D+) \cdot P(D+)+P(T+\mid D-) \cdot P(D-)}
$$

Op identieke wijze kunnen de overige drie a posteriori kansen worden afgeleid: de kans op niet-ziek zijn gegeven een positieve testuitslag $\mathrm{P}(\mathrm{D}-\mid \mathrm{T}+)$, de kans op ziekte gegeven een negatieve testuitslag $\mathrm{P}(\mathrm{D}+\mid \mathrm{T}$-) en de kans op niet-ziek zijn gegeven een negatieve testuitslag P(D-|T-).

Een complicerende factor bij het hanteren van het predictieve waardemodel is het feit dat deze a posteriori kansen sterk afhangen van de waarde van de a priori kans. Zo kan berekend worden dat de voorspellende waarde van een positieve testuitslag van een test met een sensitiviteit en specificiteit van .95 bij een prevalentie van .001 gelijk is aan .019 (d.w.z. de kans op de ziekte verhoogt met een factor 20) en bij een prevalentie van .5 gelijk is aan .95, d.w.z. de kans verhoogt met een factor 2. Deze resultaten worden bepaald door exacte mathematische rekenregels, maar zijn niet zo gemakkelijk intuitief invoelbaar, hetgeen in verschillende proefopstellingen werd bewezen (Casscells, 1981). In de medische praktijk wordt dit verschijnsel vaak niet voldoende onderkend bij de evaluatie van tests. Zo kan eenzelfde test, indien deze wordt toegepast in een populatie met verschillende a priori kansen, leiden tot zeer verschillende uitkomsten (Applegate, 1981), Op grond hiervan dient enige voorzichtigheid in acht genomen te worden bij het in de huisartsenpraktijk toepassen van tests afkomstig uit de klinische praktijk (Knottnerus, 1986).

In Galen \& Gambino (1975) wordt het predictieve waardemodel ontwikkeld en toegepast op een aantal verschillende testsituaties. Diamond \& Forrester (1979) passen het model toe bij het opsporen van atherosclerose van de coronaire vaten. Op basis van bestaande literatuur zijn door deze auteurs schattingen gemaakt van de a priori kansen op de ziekte, waarbij gebruik gemaakt is van gegevens uit anamnese en lichamelijk onderzoek. Verder zijn er gegevens verzameld over de sensitiviteit en de specificiteit 
van een viertal tests. De a posteriori kansen zijn bepald met behulp wan de bekende Bayesiaanse formules. De aldus berekende a posteriori kansen stemmen in hoge mate overeen met de werkelijk geobserveerde kansen, waarmee de bruikbaarheid van de methoden en waarschijnlijk ook de juistheid van de aannames, zoals bijwoorbeeld onafhankelijkheid van tests, onderstreept wordt.

\subsubsection{Likelihood ratio}

In deze paragraaf zal kort ingegaan worden op een andere wijze van weergave van het onderscheidend vermogen van tests, namelijk door middel van likelihood ratio's. Hiervoor is het nodig om het begrip "odds" of kansverhouding te introduceren (Weinstein, 1980). Indien de kans op winst $1: 5$ is en de kans op verlies $4: 5$ dan wordt het kansspel gekenmerkt door een kansverhouding van 1: 4 (de kans op winst ten opzichte van verlies is 1 tegen 4 ). Op een dergelijke wijze kan ook de odds bij ziekte worden bepaald, waarbij onderscheid gemaakt kan worden tussen a priori odds (PI) en a posteriori odds (PO). De a priori odds zjjn op de volgende wijze verbonden met de a posteriori odds (Lusted, 1978).

$$
\frac{P(D+\mid T+)}{P(D-\mid T+)}=\frac{P(D+)}{P(D-)} \cdot \frac{P(T+\mid D+)}{P(T+\mid D-)}
$$

ofwel

$$
\begin{aligned}
& \mathrm{PO}=\mathrm{PI}, \mathrm{L}(+) \\
& (\text { a posteriori odds }=\text { a priori odds - likelihood ratio pos. testuitslag) }
\end{aligned}
$$

De likelihood ratio vervult de brugfunctie tussen deze twee odds. Is de odds vóor de test $1: 10$ en na de test $3: 10$ dan is de likelihood ratio 3. De likelihood ratio's van zowel de positieve als de negatieve testuitslag kunnen overigens in een $2 \times 2$ situatie rechtstreeks bepaald worden met behulp van de sensitiviteit en de specificiteit op de volgende wijze.

De likelihood ratio van een positieve test $L(+)$ is gelijk aan de kans op een positieve testuitslag gegeven de ziekte gedeeld door de kams op cen positieve testuitslag gegeven het feit dat de persoon niet ziek is. In formulevorm:

$$
L(+)=P(T+\mid D+) / P(T+\mid D-)=S e /(1-S p)
$$

De likelihood ratio van een negatieve testuitslag is:

$$
L(-)=P(T-\mid D+) / P(T-\mid D-)=(1-S e) / S p
$$


Indien een testsituatie gekenmerkt wordt door een likelihood ratio van 1 dan is er sprake van een waardeloze test. De a posteriori kans is dan gelijk aan de a priori kans. Verder kan worden aangetoond dat alleen tests met een uitzonderlijk scheidend vermogen $(L(t)>100)$ al bij lage waarden van a priori kansen a posteriori kansen bereiken die dicht bij 1 liggen.

Op zichzelf gezien is het hanteren van de likelihood ratio waardevol en kan betrokken worden bij de evaluatie van tests c.q. testsituaties, zeker indien de uitkomsten van zorg, volgend op de test, buiten beschouwing blijven. Lusted (1978) hanteert een logaritmische transformatie om de waarde van een test ait te drukken, uitgaande van formule $(4.5)$.

$$
\log L(+)=\log P 0-\log P I
$$

De logaritmische transformatie komen we eveneens tegen in paragraaf 4.4.

\subsection{DE ROC-CURVE}

In de voorgaande paragraaf zijn we ervan uitgegaan dat zowel de testuitslag als de ziektesituatie te classificeren is in een tweetal klassen. De criteria op grond waarvan men besluit een testuitslag positief of negatief te noemen zijn vaak arbitrair en hetzelfde geldt ten aanzien van de ziektesituatie. In deze paragraaf veronderstellen we dat het testkenmerk verschillende waarden kan doorlopen. Ook in situaties waarin eigenlijk sprake is van een dichotomie is het vaak mogelijk meerdere klassen te creëren (Metz, 1978). Indien het bijvoorbeeld situaties betreft waarbij testuitslagen geïnterpreteerd moeten worden, kan aan de beoordelaars gevraagd worden hoeveel vertrouwen zij hebben in hun beoordeling. Een indeling in vijf categorieën lijkt vaak adequat, bijvoorbeeld een indeling in:

- absoluut zeker negatief,

- waarschijnlijk negatief,

- mogelijk positief,

- waarschijnlijk positief,

- zeker positief.

In een dergelijk geval zijn er vier verschillende wijzen waarop onderscheid gemaakt kan worden tussen positieve en negatieve testuitslagen. Als meest strikte criterium kan gehanteerd worden: alleen de beoordelingen, waarvan de beoordelaar absoluut zeker is, worden positief genoemd. De drempel kan in principe echter ook tussen alle andere categorieën worden gelegd. Een toepassing van dit principe is te vinden bij Reit \& Gröndahl (1983).

In het onderstaande gaan we ervan uit dat er twee verdelingen zijn, de populatie van zieken en de populatie van niet-zieken, welke op een bepaalde manier verdeeld zijn over een kenmerk. In onderstaande figuur is een aantal mogelijke distributies weergegegeven. 
Figuur 4.1. Mogelijke verdelingen zieken en niet-zieken
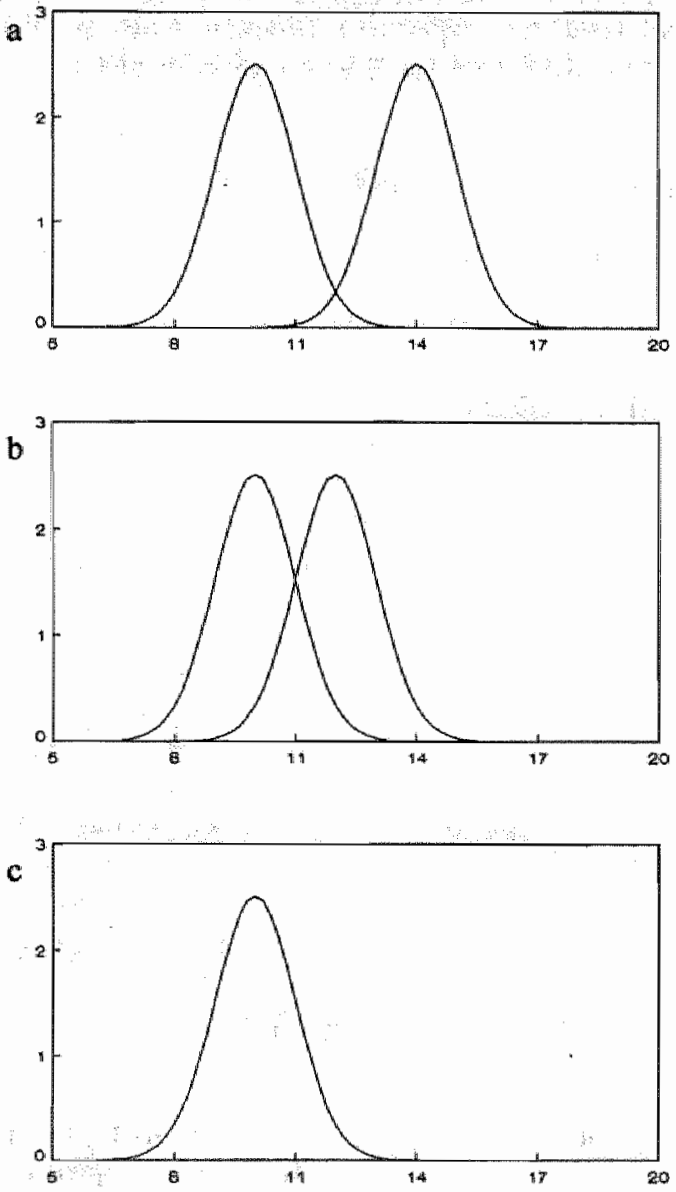

Vergelijken we situatie a met $c$ dan blijkt dat in de eerste situatie wel een onderscheid te maken is tussen zieken en niet-zieken terwijl dit bij c onmogelijk is, zolang we het betreffende kenmerk hanteren. In de situaties a en b bestaat er een zekere mate van vrijheid bij het hanteren van afkappunten, zoals bijvoorbeeld het geval is bij het inspannings-ECG, waar de ST-depressie wordt gemeten in millimeters. Nu kan men van een positieve testuitslag spreken indien deze afwijking meer dan 1 millimeter bedraagt, maar evenzo zou men 1,5 millimeter kunnen hanteren als afkappunt, etc. Het is duidelijk dat bij 2 millimeter als afkappunt de sensitiviteit van de test lager is dan bij 1 millimeter. Er worden in dat geval minder personen door de test ziek genoemd. Bij hantering van een ruimer afkappunt, bijvoorbeeld 1 millimeter, worden meer zieke personen opgespoord. Dit zou ervoor pleiten om het criterium zo ruim mogelijk te stellen maar het vervelende is dat daarmee tevens uit de groep niet-zieke personen een groter aantal personen ten onrechte als ziek wordt gekenmerkt, met alle vervelende 
gevolgen van dien (kostenconsequenties in de zin van vervolgtests naast psychologische factoren als angst bij deze patienten). Het is duidelijk dat er in dit geval sprake is van een trade-off tussen sensitiviteit en specificiteit, d.w.z. verhoging van de sensitiviteit gaat gepaard met een verlaging van de specificiteit en omgekeerd.

Het is mogelijk dit verband tussen sensitiviteit en specificiteit weer te geven in een figuur. De ROC-curve (Receiver Operating Characteristic) geeft aan op welke wijze deze trade-off tussen sensitiviteit en specificiteit gestalte krijgt:

Figuur 4.2. ROC-curve

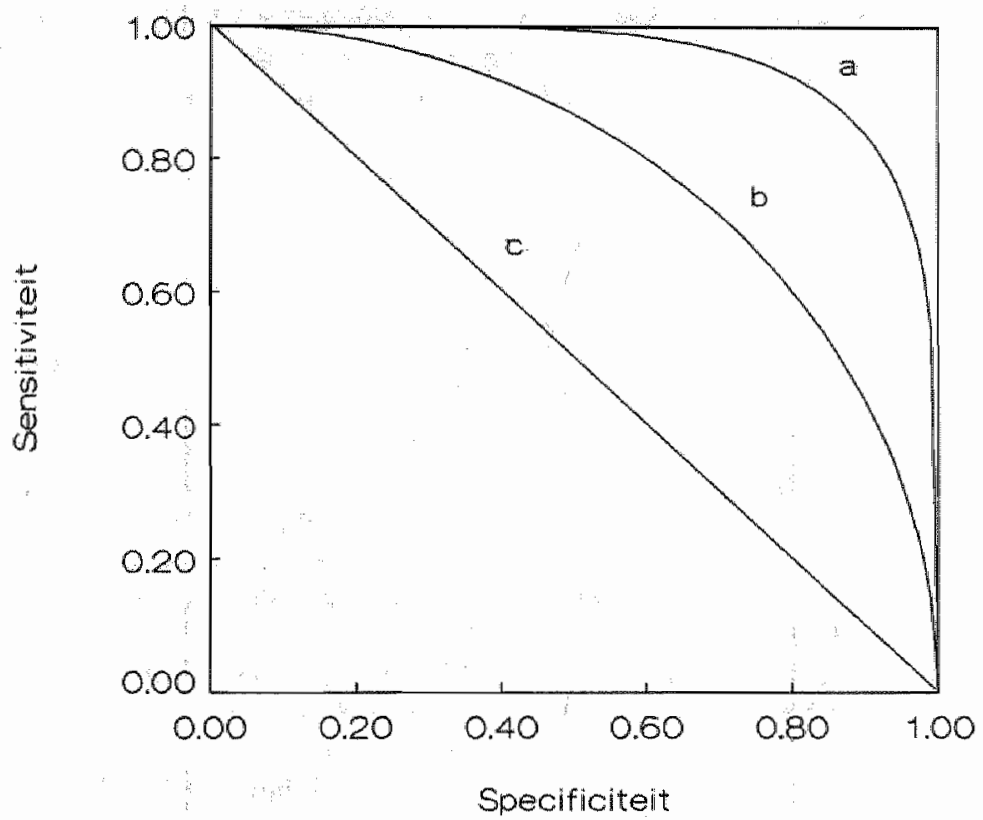

In de grafiek is de ROC-curve weergegeven, welke behoort bij de situaties $a$ of $b$ in de voorgaande grafiek. De $45^{\circ}$-lijn vertegenwoordigt de waardeloze test (c). In situatie a is het beter mogelijk dan bij b om onderscheid te maken tussen zieken en niet-zieken, hetgeen resulteert in een meer gebogen ROC-curve in situatie a:

De kromming van de ROC-curve wordt bepaald door de vorm en de positie van de verdelingen van zieken en niet-zieken ten opzichte van elkaar. Hierop heeft de persoon die de test hanteert geen invloed. Wel kan deze persoon zich afvragen welk punt het best gehanteerd kan worden als afkappunt om onderscheid te maken tussen zieken en niet-zieken. Dit probleem wordt in hoofdstuk 6 behandeld, waarbij de therapeutische consequenties mede in de beschouwing worden betrokken. Ook los van deze consequenties zijn er algemene opmerkingen te maken ten aanzien van de ROC-curve. De sensitiviteit en specificiteit van tests blijkt soms af te hangen van de beschikbaarheid van informatie uit anamnese en lichamelijk onderzoek. Indien artsen bijvoorbeeld röntgenfoto's interpreteren in het licht van voorafkennis over bepaalde hypothesen, 
blijkt de sensitiviteit hoger te zijn dan het geval is zonder de betreffende informatie (Doubilet \& Herman, 1981).

In de tweede plaats kan gesteld worden dat, indien de a priori kans op ziekte laag is, met name de specificiteit hoog moet zijn. Bij een te lage specificiteit dreigt het aantal fout-positieven hoog te worden, waardoor de voorspellende waarde van een positieve testuitslag laag uitvalt. M.a.w. indien de a priori kans laag is, zal men geneigd zijn om een afkappunt te kiezen, gekenmerkt door een relatief lage sensitiviteit en een relatief hoge specificiteit. Overigens kan daarbij niet een te extreem standpunt worden ingenomen omdat de sensitiviteit anders te laag wordt en dus een (te) gering gedeelte van de zieken opgespoord wordt (Sackett, 1975).

In hoofdstuk 1 is ingegaan op het onderscheid tussen ruling-in en ruling-out tests. Is een test bedoeld om hypothesen in te sluiten dan is vooral de voorspellende waarde van een positieve testuitslag van belang (Bennington, 1981). Bij lage a priori kansen wordt de voorspellende waarde met name door de specificiteit bepaald. Een ruling-in test dient dan vooral een hoge specificiteit te hebben. Op identieke wijze kan afgeleid worden dat bij een ruling-out test de negatieve testuitslag van belang is en dus een hoge sensitiviteit. Bennington (1981) wijst er overigens terecht op dat voor het uitsluiten van een ziekte met een hoge waarschijnlijkheid van optreden, juist een hoge specificiteit van belang is, hetgeen te verklaren is op grond van de werking van de a priori kans in het voorspellende waarde-model.

Met betrekking tot tests die gebruikt worden voor screeningsdoeleinden komt Sackett (1975) tot de conclusie dat het afkappunt een hoge sensitiviteit dient te hebben, terwijl Sturmans (1986) juist een hoge specificiteit belangrijk vindt. Sackett definieert het primaire doel van screening als: het opsporen van zieke personen. Hiermee geeft hij aan, dat het missen van een ziek persoon (FN) de fout met de grootste consequenties is. Sturmans legt de nadruk op de invloed van de lage prevalentie, waarvan in screeningssituaties vaak sprake zal zijn. Op grond daarvan is hij van mening, dat een lage specificiteit leidt tot een groot aantal fout-positieve uitslagen met alle vervelende consequenties van dien voor de personen.

Een meer definitief standpunt ten aanzien van deze vraag kan worden bepaald aan de hand van een evaluatie, waarbij alle gezondheids- en kostenaspecten van de test worden betrokken.

In hoofdstuk 6 wordt deze methode beschreven. Het bepalen van met name de te behalen gezondheidswinst is gecompliceerd. Indien deze bepaling achterwege blijft, dan is er een aantal methoden beschikbaar om ROC-curves te beoordelen. In de eerste plaats geeft de kromming van de functie zelf reeds veel informatie over het discriminerend vermogen van tests. Een hierop gebaseerde maatstaf is het bepalen van het oppervlak onder de ROC-curve (McNeil, 1982). Deze methode kan overigens worden toegepast onafhankelijk van de vorm van de onderliggende verdelingen van zieken en niet-zieken. Bij grotere onderzoekspopulaties $(\mathrm{N}>30)$ kan beter de oppervlaktemaat worden gebruikt (Hermann \& Sugiura, 1984). Bij kleine onderzoekspopulaties is de Wilcoxon rank-sum een goede maatstaf voor de onderlinge vergelijking van ROC-curves. De oppervlaktemaatstaf, die zinvol te interpreteren is bij signaaldetectie, lijkt echter minder geschikt voor gebruik in de geneeskunde (Metz, 1973).

McNeil (1982) wijst op de mogelijkheid om ROC-curves weer te geven als rechte lijnstukken door deze weer te geven op zgn. "double probability" papier (ook wel genoemd "binormaal grafisch papier"). De richtïngscoëfficiènt van de lijn en het 
intercept wan de $\mathrm{x}$-as kumnen dan gebruikt worden om de wolledige $\mathrm{ROC}$-curve te kunnen karakteriseren. Indien symmetrische ROC-curves op deze wijze op binormaal papier worden weergegeven, vertonen ze een hellingshoek van $45^{\circ}$ (Swets \& Pickett, 1982).

Indien de gegevens van tests met meer dan wee witslag-categorieen worden weergegeven met behulp van een $2 \times 2$ tabel gaat er onherroepelijk informatie verloren. Om dit verlies aan informatie te voorkomen kunnen ROC-curves gebruikt worden die de volledige range van mogelijke testuitslagen expliciet in de beschouwing betrekken, maar kan ook gebruik gemaakt worden van likelihood ratio's (Beck, 1982).

De berekening van de likelihood ratio's heeft in feite alleen zin in het gebied waar de verdelingen van zieken en niet-zieken elkaar overlappen. Daarbuiten is de waarde ervan gelijk aan nul of gelijk aan oneindig. Keller \& Gessner (1981) stellen voor om de logaritmen te bepalen van de likelihood ratio's, die in het overlappende gedeelte voorgesteld kunnen worden door een exponentiële functie. Op deze wijze kan de werking van een test weergegeven worden middels de coefficiênten van een rechte lijn. De volledige informatie die in de ROC-curve ligt opgesloten blijft aldus behouden.

Het concept van likelihood ratio's kan ook uitgebreid worden naar situaties waar sprake is van het toepassen van meerdere tests, waarbij deze tests dichotoom, dan wel discreet of continu mogen zijn.

De likelihood ratio's van twee of meerdere omafhankelijke tests kunnen worden bepaald door het product van de afzonderlijke likelihood ratio's. Bij combinatie van meerdere afhankelijke testen kan de totale likelihood ratio bepaald worden door de productregels van voorwaardelijke kansen toe te passen (Albert, 1982).

\subsection{VERWACHTINGSWAARDE ONZEKERHLIDSREDUCTIE}

Connell \& Koepsell (1985) hebben recent aangegeven hoe een test kan worden geèvalueerd door nader in te gaan op de mate van onzekerheidsreductie. $\mathrm{Zij}$ beschouwen het diagnostisch proces als een op zichzelf staand geheel, los van de eventuele therapeutische opbrengsten. $\mathrm{Zij}$ definiëren de opbrengst van een test in termen van informatie over de (on)zekerheid betreffende het bestaan wan ziekten. De predictieve waarde van testuitslagen is in hun visie niet van doorslaggevende betekenis maar wel het verschil tussen de a priori kans en de a posteriori kans. Als maatstaf voor de "winst in zekerheid" stellen zij de volgende criteria woor:

- het netto verschil tussen a priori en a posteriori kans op de ziekte,

- het netto verschil tussen a priori en a posteriori kans op de ziekte als percentage van de a priori kans;

- het netto verschil tussen a priori en a posteriori kans op de ziekte als percentage van de maximaal haalbare winst in zekerheid.

Met deze indices kan de winst in zekerheid gekwantificeerd worden voor zowel de positieve als de negatieve testuitslag. Om een indruk te krijgen van het gedrag van een test berekenen zij de verwachtingswaarde, d.w.z. de opbrengst wit een positieve test wordt vermenigvuldigd met de kans op een positieve testuitslag. De opbrengst van een negatieve test wordt vermenigvuldigd met de kans op een negatieve testuitslag. In deze benadering wordt dus geen aandacht besteed aan de foute uitspraken (zie hierna). 
In formulevorm kan de winst in mate van zekerheid als volgt worden weergegeven:

$W=P(T+) \cdot\{P(D+\mid T+)-P(D+)\}+P(T-) \cdot\{P(D-\mid T-)-P(D-)\}$

waarbij de eerste term de winst in zekerheid weergeeft van een positieve testuiltslag, gewogen met de kans op een positieve testuitslag en de tweede term betrekking heeft op de negatieve testuitslag. In het gebied waarvoor geldt $\mathrm{Se}+\mathrm{Sp}>1$ (dat wil zeggen het gebied boven de $45^{\circ}$-lijn, zie figuur 4.2 ) geldt tevens dat

$$
P(D+\mid T+)>P(D+)
$$

en

$$
\mathrm{P}(\mathrm{D}-\mid \mathrm{T}-)>\mathrm{P}(\mathrm{D}-)
$$

zodat in dat gebied W altijd positief is. Voor de eerste ongelijkheid kan dit eenvoudig aangetoond worden door gebruikmaking van formule (4.4).

Deze formule heeft betrekking op de eerste van de drie genoemde criteria. Op identieke wijze kunnen đe formules met betrekking tot criteria 2 en 3 worden afgeleid.

Deze formule (4.9) kan vereenvoudigd worden tot:

$$
\mathrm{W}=2 \mathrm{p}(1-\mathrm{p})(\mathrm{Se}+\mathrm{Sp}-1)
$$

(voor afleiding zie bijlage 1)

Indien de som van sensitiviteit en specificiteit groter is dan een, is de waarde van W altijd groter dan nul. In de volgende figuur wordt het resultaat weergegeven van een gevoeligheidsanalyse met betrekking tot de a priori kans uitgaande van een drietal tests. De drie tests hebben de volgende kenmerken:

test 1 is een test met zowel een hoge sensitiviteit als een hoge specificiteit, test 2 heeft een hoge sensitiviteit en gemiddelde specificiteit, test 3 heeft een gemiddelde sensitiviteit en een hoge specificiteit.

"Hoog" staat voor .95 en "gemiddeld" voor .75 .

In onderstaande grafiek zijn de resultaten weergegeven van hun analyse waarbij onderscheid gemaakt wordt tussen positieve en negatieve testuitslagen. Daarbij dient bedacht te worden dat zowel de toename van de kans op de ziekte bij een positieve testuitslag als ook de daling van de kans op de ziekte bij een negatieve testuitslag als winst kan worden gezien. 
Figuur 4.3. Onzekerheidsreductie bij positieve en negatieve testuitslagen (Connell \& Koepsell, 1985)

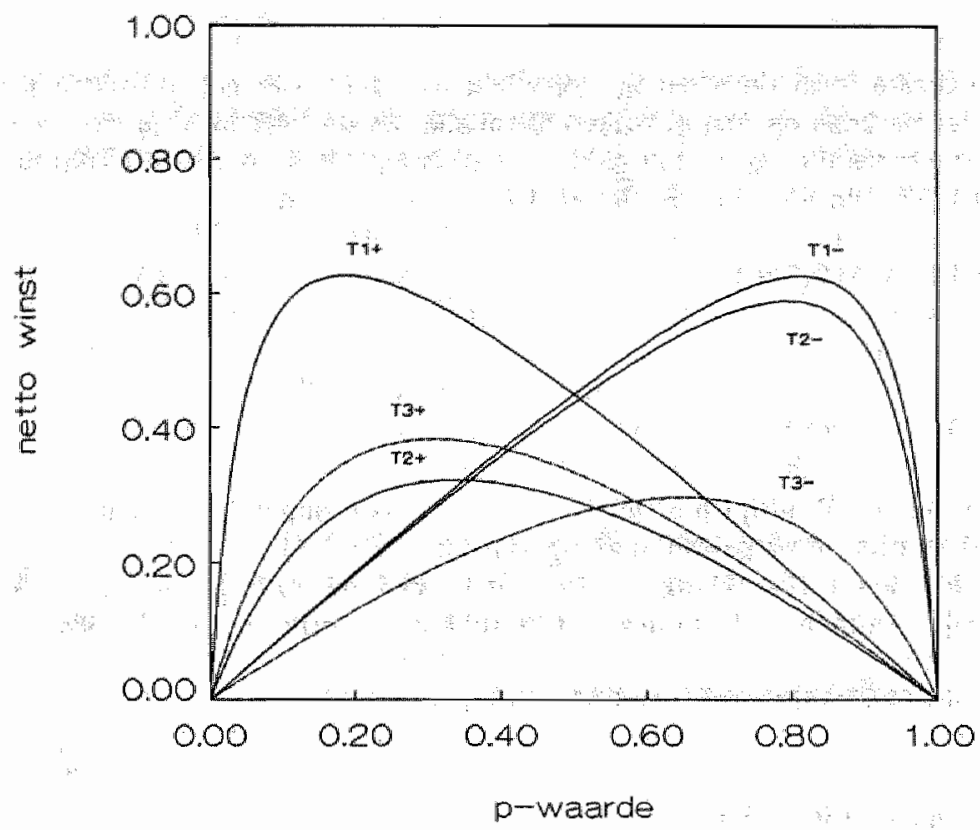

De figuur is in de eerste plaats een illustratie van het feit, dat bij prevalenties kleiner dan 5 de reducties in onzekerheid met name veroorzaakt worden door positieve testuitslagen en bij prevalenties groter dan 5 door negatieve testuitslagen.

Indien de prevalentie laag is, heeft een daling van de sensitiviteit wel effect op de te behalen winst, voorzover het de positieve testuitslag betreft, maar dit effect is niet groot. Daling van de specificiteit heeft een veel grotere invloed. Met andere woorden bij lage prevalenties zal met name gekeken moeten worden naar de hoogte van de specificiteit van de test. Verder is vooral een eventuele positieve uitslag in een dergelijke situatie van belang.

Bij hoge prevalenties is op identieke wijze te beredeneren dat met name de negatieve testuitslag veel informatieve waarde heeft, en dat de sensitiviteit van de test van groot belang is. Bij het bepalen van het optimale afkappunt zal met invloed van de prevalentie rekening moeten worden gehouden (zie hoofdstuk 6).

In de navolgende beschouwing zijn we niet zozeer geinteresseerd in de opbrengst van de afzonderlijke testuitslagen als wel in het total van het testgedrag, m.a.w. de verwachtingswaarde van de winst in zekerheid. Aan de hand van formule (4.10) kunnen de volgende conclusies getrokken worden. De potentielle winst in zekerheid die kan worden behaald gegeven een bepaalde a priori kans, kan worden bepaald door voor sensitiviteit en specificiteit in de formule (4.10) Cén in te vullen. De potentiële winst is het grootste voor $\mathrm{p}=.5$. 
De situatie, die gekenmerkt wordt door een a priori kans van 5 is een situatie van maximale onzekerheid omtrent het al of niet aanwezig zijn van ziekte. Verder is de winst gelijk aan nul indien de a priori kans gelijk is aan nul of én. In beide situaties bestaat er in feite volledige zekerheid.

Een volgende constatering is dat het voor de totale opbrengst niet uitmaakt of de sensitiviteit hoog en de specificiteit laag is dan wel omgekeerd, als de som van sensitiviteit en specificiteit maar gelijk blijft. Deze constatering kan ook rechtstreeks ontleend worden aan formule (4.10), waar onderlinge verwisseling van sensitiviteit en specificiteit geen verschil uitmaakt.

Hoe is dit te rijmen met voorgaande constateringen dat verschillen in sensitiviteit en specificiteit wel degelijk een rol spelen bij de evaluatie van tests? Bovenstaande maatstaf omvat de totale onzekerheidsreductie welke door de test kan worden geëffectueerd, waarbij zowel de positieve als de negatieve uitslagen een rol spelen. Of er sprake is van een negatieve dan wel een positieve uitslag is onbelangrijk bij een evaluatie vanuit een a priori standpunt. Een dergelijke benadering zou men een waardevrije evaluatie kunnen noemen, omdat in een dergelijke benadering geen rekening wordt gehouden met het doel waarvoor de test wordt aangevragd noch met de eventueel te behalen gezondheidswinst.

Aan deze methodiek is uitgebreid aandacht besteed, omdat er een zekere parallel bestaat met de hierna te bespreken methodiek ontleend aan de informatietheorie en omdat het model te beschouwen is als overgangssituatie naar het besliskundig model dat in de navolgende hoofdstukken besproken wordt.

\subsection{INFORMATIETHEORIE}

In deze paragraaf zal ingegaan worden op de bijdragen vanuit de informatietheorie aan de evaluatie van tests. Daarbij zal niet zozeer ingegaan worden op theoretische aspecten maar zal meer nadruk gelegd worden op toepassingsmogelijkheden met name in relatie tot de in de voorgaande paragraaf beschreven methodiek om onzekerheild te reduceren. Kort zal ingegaan worden op de achtergronden van de methodiek, waarbij het centrale begrip "entropie" wordt geïntroduceerd. Vervolgens worden enkele toepassingen beschreven.

Aan het begrip informatie wordt in deze theorie een speciale betekenis toegekend. In de spreektaal slaat het begrip informatie vaak op de inhoudelijke betekenis van berichten (semantische betekenis). In de informatietheorie gaat het bij informatie zuiver en alleen om de syntactische aspecten. Daarbij is het niet van belang wat de inhoud is, maar wat de inhoud kan zijn. Informatie heeft te maken met het aantal vrijheidsgraden bij de keuze van een bericht (Shannon \& Weaver, 1972). De informatie wordt gemeten door de logaritme te nemen van de reciproke waarde van de kans van optreden. Indien de logaritme tot de basis 2 wordt gebruikt, wordt de informatie uitgedrukt in binary digits ofwel "bits".

Wat betekent dit concreet? Indien er in een bepaalde situatie vier mogelijkheden zijn (bijvoorbeeld eén munt kan zich bevinden in eén van vier bloempotten) dan wordt deze situatie gekarakteriseerd door twee bit aan informatie. Door het stellen van twee ja/nee vragen (en het verkrijgen van de juiste antwoorden) kan de plaats van de munt worden achterhaald. Zijn er acht bloempotten dan is met behulp van drie ja/nee vragen de 
plaats van de munt bepaald. Kennis omtrent de ligging van de munt bevat dan 3 bits aan informatie. Veralgemeniseren we dit dan blijkt kennis ower de plaats van de munt in een situatie met $2^{\text {n }}$ mogelijkheden $n$ bit aan informatie te bevatten. Hetzelfde resultaat verkrijgen we door de ${ }^{2} \log$ te nemen van de reciproke van de kans dat de munt zich in een willekeurige bloempot bevindt. $\mathrm{Bij}$ acht bloempotten geldt $\mathrm{p}=1 / 8$ en is de informatie-inhoud $\mathbb{I}={ }^{2} \log (1 /(1 / 8))=3$.

Stel dat er twee mogelijke gebeurtenissen zijn met bijbehorende kansen van optreden van $p_{1}$ en $p_{2}=1-p_{1}$. Maximale onzekerheid heerst er indien $p_{1}=p_{2}=1 / 2$ en minimale onzekerheid heerst er indien $p_{1}=0$ of $=1$.

Het begrip entropie wordt in de informatietheorie gedefinieerd als de verwachtingswaarde van de informatie van de afzonderlijke gebeurtenissen, in formulevorm:

$$
H=+\Sigma p_{i}{ }^{2} \log \left(1 / p_{i}\right)\left(=-\Sigma p_{i}{ }^{2} \log p_{i}\right)
$$

De entropie is dus een maatstaf woor onzekerheid.

Bij een situatie waar twee gebeurtenissen kunnen optreden kan deze $\mathrm{H}$-waarde worden bepaald voor iedere waarde van $p_{1}$, waarbij duidelijk wordt dat $H$ maximaal 1 is (bij $p_{1}=1 / 2$ ) en minimaal 0 (bij $p_{1}=0$ of 1 ). Hierbij valt op dat deze wijze van kenmerken van onzekerheid grote gelijkenis vertoont met de manier die in de voorgaande paragraaf is beschreven. Op de overeenkomsten en verschillen wordt later ingegaan (zie par. 4.6).

De H-curve geeft tevens de maximale winst in informatie aan die behaald kan worden bij iedere a priori kans. Grafisch kan de $\mathrm{H}$-curve als volgt worden weergegeven als een functie van $\mathrm{p}_{1}$ :

Figuur 4.4 Entropie

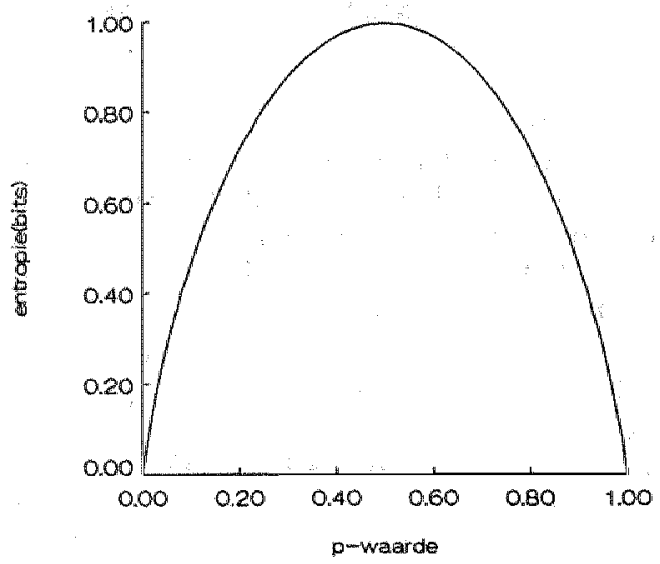


Dit concept van entropie kan nu ook gebruikt worden om de mate van onzekerheid te meten nadat een bepaald bericht over de ware gebeurtenis(sen) is ontvangen, of, wat hetzelfde is, door hoeveel onzekerheid een situatie wordt gekenmerkt nadat een bepaalde test is uitgevoerd (Barnoon \& Wolfe, 1972). Hieronder zal een enigszins aangepaste notatie worden gehanteerd:

$\mathrm{i}=$ mogelijke ziektecategorie

$\mathrm{j} \quad=$ mogelijke testuitslag

$P\left(D_{i}\right)=$ kans op ziekte i

$P\left(T_{j}\right)=$ kans op testuitslag $j$

Vóordat de test is uitgevoerd, wordt de situatie gekenmerkt door de a priori onzekerheid. De entropie is dan:

$$
H_{\text {pre }}=-\underset{i}{i} P\left(D_{i}\right){ }^{2} \log P\left(D_{i}\right)
$$

Nadat de test is uitgevoerd kan met behulp van de a posteriori kansen de onzekerheid gekwantificeerd worden middels

$$
H_{\text {post }}=-\underset{j}{\sum} P\left(T_{j}\right) \underset{i}{\sum} P\left(D_{i} \mid T_{j}\right)^{2} \log P\left(D_{i} \mid T_{j}\right)
$$

Hierbij valt op dat de a posteriori kansen in formule (14) eenzelfde bewerking ondergaan als de a priori kansen in formule (13). Er dient echter nog een weging plaats te vinden met de kans op de respectievelijke testuitslagen, teneinde de verwachtingswaarde te verkrijgen. De gemiddelde winst in zekerheid ten gevolge van het uitvoeren van een test, ook wel mutuele entropie genaamd, uitgedrukt in bits, bedraagt derhalve

$$
H_{m}=H_{p r e}-H_{p o r t}=\sum_{i=1}^{m} \sum_{j=1}^{n} p_{i j}^{2} \log \frac{p_{i j}}{p_{i} \cdot p_{j}}
$$

waarbij geldt:

$p_{i j}=$ kans op ziektecategorie $i$ en testuitslag $j$

$p_{i}=\sum_{j=1}^{n} p_{i j}$ 
$p_{j}=\sum_{i=1}^{m} p_{i}$

(voor afleiding zie bijlage 2).

Met behulp van deze formule kan de waarde van een test $\left(\mathrm{H}_{m}\right.$ mutuele entropie) worden bepaald in bits.

Overigens kunnen de a posteriori kansen weer worden herschreven met behulp van a priori kansen, waardoor deze basisformule andere verschijningsvormen kan aannemen (zie bijwoorbeeld Diamond e.a., 1981). Voor een handzame berekeningswijze van de mutuele entropie verwijzen we naar bijlage 2 waar een eenvoudig cijfervoorbeeld is uitgewerkt aan de hand van een methode ontleend aan Büttner (1977),

Toepassingen van dit informatie-concept zijn o.a. te vinden bij Eeckhoudt e.a. (1985), Gift e.a. (1985) en Ulm e.a. (1981). Deze laatste toepassing heeft betrekking op de opsporing van patiènten met vaataandoeningen met vier verschillende niet-invasieve tests:

1. ECG bij rust

2. hartfrequentie gedurende inspanning

3. Inspannings-ECG

4. Thallium 201 scintigrafie

Berekend is met behulp van de maatstaf entropie hoeveel reductie in onzekerheid optreedt na uitvoering van de diverse tests. De aanvangsonzekerheid in bits bij een a priori kans van .7333 bedraagt in deze studie 8366 . De entropie bedraagt na iedere test, in de bovengemelde volgorde, respectievelijk .7039, $.5207,3862$ en .3478 , waarbij de reductie in de laatste stap niet statistisch significant meer is. Dit impliceert dat uitvoering van de thallium scintigrafie na de drie overige tests weinig zinvol is. Wordt het vermogen om onzekerheid te reduceren per test bepaald, dan blijkt de thallium scintigrafie daartoe echter het best in staat. De entropie na het uitvoeren van de scintigrafie bedraagt ongeveer evenveel als de entropie na uitvoering van de overige drie tests.

Een voorbeeld waarbij er twee mogelijke ziektesituaties zijn (D+ en D-) en eén test beschikbaar is met $j$ mogelijke uitslagen wordt beschreven door Diamond e.a. (1981). Dit voorbeeld heeft betrekking op het inspannings-ECG. Bij de interpretatie van het inspannings-ECG speelt de problematiek van het afkappunt. Bij welke afwijking (in millimeters gemeten) van de ST-depressie spreekt men van een positieve of negatieve testuitslag? De literatuur is door de auteurs gescreend om schattingen te krijgen over de sensitiviteit en de specificiteit van de test bij verschillende mogelijke afkappunten (van $.5 \mathrm{~mm}$ tot $2,5 \mathrm{~mm}$ ). Hoe hoger het afkappunt des te geringer wordt de sensitiviteit en des te hoger de specificiteit.

In de analyse wordt een tweetal wegen bewandeld. Bij de dichotome analyse worden de testuitslagen gedichotomiseerd, waarbij zich het probleem voordoet welk afkappunt 
het beste is. Bij de polytome analyse wordt het volledige spectrum van testuitslagen toegestaan.

Hantering van het afkappunt $1 \mathrm{~mm}$ blijkt het beste uit het oogpunt van onzekerheidsreductie, behalve wanneer de a priori kans erg hoog is $(p>.7)$. In dat geval kan beter $.5 \mathrm{~mm}$ als afkappunt gehanteerd worden. Ook wordt duidelijk dat het inspannings-ECG relatief weinig informatie bevat indien de informatie gemeten wordt in bits. De test is maximaal in staat de totale onzekerheid omtrent het bestaan van ziekte te reduceren met zo'n $20 \%$. Bij hoge en lage prevalenties is dit nog veel minder.

Bij hantering van het gehele scala wan testuitslagen blijkt dat de informatiewaarde van de polytome benadering hoger is dan het geval is bij dichotomisering van testuitslagen (zie bijvoorbeeld Detry e.a., 1985). M.a.w. bij het dichotomiseren van tests gaat informatie verloren. Met behulp van het entropie-concept is dit verlies aan informatie te kwantificeren. Dit verlies aan informatie wordt overigens voorspeld door de informatietheorie, die stelt dat de informatiewaarde groter is naarmate er meerdere, wederzijjs uitslustende, testcategorieën worden gebruilkt.

\subsection{VERGELIJKING CONNELL EN KOEPSELL MET SHANNON}

In het hoofdstuk is ingegaan op enkele methoden met behulp waarvan de waarde van tests kan worden bepaald. Deze methoden hebben als gemeenschappelijk kenmerk dat zij in principe geen rekening houden met de uitkomsten van het therapeutisch proces. De methoden richten zich derhalve uitsluitend op de veranderingen in kansen op ziekte ten gevolge van het uitvoeren van tests. De sensitiviteit en specificiteit hebben een grote invloed op deze veranderingen, maar ook de a priori kans op de ziekte speelt een belangrijke rol.

Het berekenen van de predictieve waarde en de analyse via de ROC-curve kunnen waardevolle bijdragen leveren aan het medisch besliskundige proces (McNeil (1982), Weinstein e.a. (1980), Lusted (1978)).

Minder duidelijk is de betekenis van het entropie-concept voor het besliskundig proces, ondanks het feit dat deze methode veelvuldig is toegepast.

In deze paragraaf zal deze laatste methodiek op een aantal punten vergeleken worden met de methode van Connell \& Koepsell, welke veel meer in lijn ligt met de voorafgaand beschreven methodes.

Hiervór is reeds gesignaleerd dat er een grote mate van overeenkomst bestaat tussen de besliskundige benadering, ontwikkell door Connell \& Koepsell en de benadering uit de informatietheorie. In beide methodes wordt de te behalen opbrengst gedefinieerd; bij Connell \& Koepsell weergegeven door de W-curve en in de informatietheorie door de H-curve.

De globale structuur van de formules is identiek. De te behalen winst bij een positieve testuitslag wordt gewogen met de kans van optreden bij een positieve testuitslag en hetzelfde geschiedt bij de negatieve testuitslag. Bij Connell \& Koepsell wordt het absolute verschil genomen tussen de a posteriori en de a priori kans. In de informatietheorie wordt uitgegaan van de verhouding tussen de a posteriori en de a priori kams. Een werschil echter is dat in de W-curve de terechte uitslagen zijn verwerkt, terwijl de H-curve ook de invloed van foute uitslagen bevat. Bovendien wordt in de informatietheorie een logaritmische transformatie toegepast. Dit leidt tot een tweetal 
interessante verschillen, welke aan de hand van de onderstaande figuren nader toegelicht zullen worden.

Figuren 4.5a en $4.5 \mathrm{~b}$. Vergelijking $\mathrm{W}$ en $\mathrm{H}_{\mathrm{m}}$
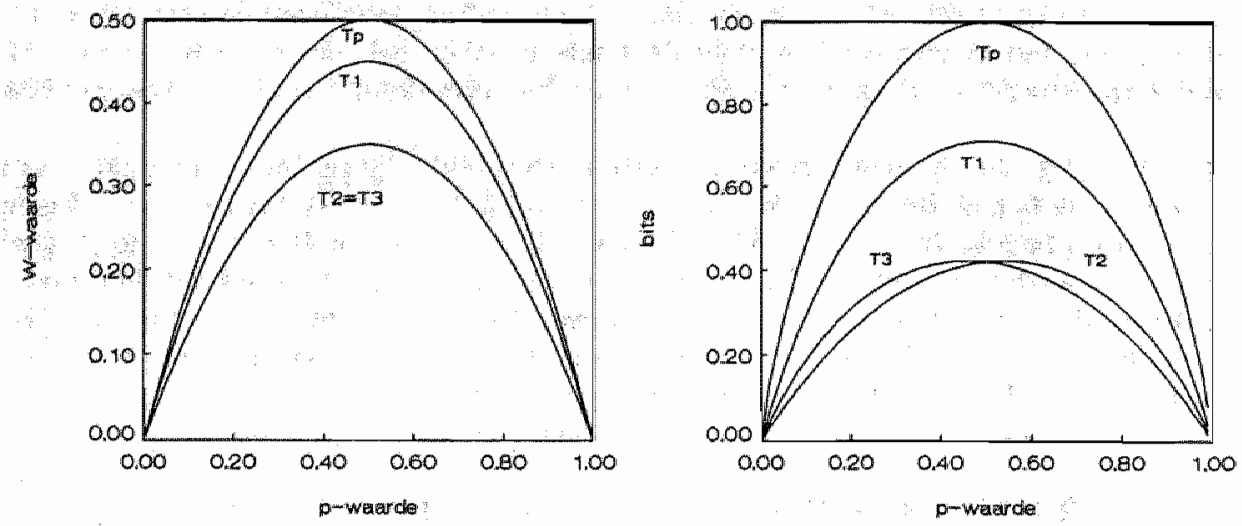

Voor de vier tests uit het artikel van Connell \& Koepsell is voor beide methoden grafisch de te behalen opbrengst weergegeven bij iedere a priori kans.

Het eerste verschil heeft betrekking op de schaal waarin de opbrengst wordt uitgedrukt. Het tweede verschil heeft te maken met de invloed van veranderingen in sensitiviteit en specificiteit op de opbrengst bij diverse a priori kansen.

\section{De opbrengstschaal}

Wordt gekeken naar het resultaat van een test met een sensitiviteit en specificiteit van .95 bij een a priori kans van .5 , dan zien we dat deze test gekenmerkt wordt door een winst in informatie van .714 bits, hetgeen bij deze prevalentie meteen gelijk staat aan $71,4 \%$ van de maximaal haalbare informatie. Bij de methode van Connell \& Koepsell wordt door een test met een sensitiviteit en specificiteit van .95 bij een prevalentie van $.590 \%$ van de maximale opbrengst behaald.

Algemeen kan gesteld worden dat er bij de methode van Connell \& Koepsell sprake is van een lineair verband tussen de hoogte van de parameters sensitiviteit en specificiteit aan de eme kant en de opbrengstmaatstaf $W$ aan de andere kant. Uit formule (10) blijkt dat deze lineaire relatie geldt, onafhankelijk van de hoogte van de prevalentie. Bij de entropie-methode is er geen sprake van een lineaire relatie.

Indien sensitiviteit en specificiteit gezien worden als productiefactoren dan dringt zich de vergelijking op met de isoquantenstructuur van productiefuncties. Indien op een assenstelsel twee productiefactoren, bijvoorbeeld arbeid en kapitaal, worden uitgezet, verbindt een isoquant elke combinatie van eenheden arbeid en kapitaal, welke resulteert in een bepaald productieniveau. Deze functies zijn convex ten aanzien van de oorsprong tengevolge van de wet van de verminderde meeropbrengsten. De bovengenoemde 
isoquanten zijn in het geval van Connell \& Koepsell rechte lijnen, hetgeen een nadere verklaring behoeft. Strikt genomen zijn sensitiviteit en specificiteit parameters welke rechtstreeks gerelateerd zijn aan de opbrengst. Ze geven aan hoeveel procent van de maximaal haalbare opbrengst kan worden behaald via een bepaalde test. Om deze test te kunnen produceren zijn eenheden kapitaal en arbeid nodig. Voorzover er sprake is van verminderende meeropbrengsten, heeft dat betrekking op het productieniveau van de test.

Het is naar alle waarschijnlijkheid veel gecompliceerder, en dus duurder, om tests met een reeds relatief hoge sensitiviteit en specificiteit $\mathrm{x} \%$ sensitiever en/of specifieker te maken, dan een test met een relatief lage sensitiviteit en specificiteit.

Voorzover er sprake is van verminderde meeropbrengsten zal dit tot uitdrukking komen in de kostprijs van de betreffende tests. Sensitiviteit en specificiteit zijn zoals gezegd gerelateerd aan de opbrengst. Bij een bepaalde specificiteit zal een toename van sensitiviteit betekenen dat een bepaald aantal zieken meer wordt opgespoord. Dit impliceert dat er sprake is van constante meeropbrengsten ten aanzien van sensitiviteit. Aangezien dit omgekeerd ook voor de specificiteit geldt, zullen de isoquanten lineair moeten zijn. Uit formule 10 blijkt tevens dat isoquanten, welke behoren bij een bepaald niveau van opbrengst (W) evenwijdig lopen aan de $45^{\circ}$. De isoquant, waarbij $W=0$, valt samen met de $45^{\circ}$-lijn. De isoquant, waarbij $\mathrm{W}=.5$ (de maximale waarde voor $\mathrm{W}$ ) gaat door het punt waar de sensitiviteit en specificiteit gelijk zijn aan cén. Verder is de onderlinge afstand van de isoquanten, met een bepaald verschil in opbrengst; overal even groot. Dit leidt tot een isoquantenstructuur voor $\mathbf{W}$, zoals weergegeven in figuur 4.6a.

Op grond van deze isoquantenstructuur kunnen een tweetal conclusies getrokken worden.

- De combinatie van sensitiviteit en specificiteit met de hoogste opbrengst in W wordt gevonden door de $45^{\circ}$-raaklijn aan de ROC-curve te trekken. Een dergelijke combinatie ligt op de isoquant met de hoogste opbrengst.

- De isoquantenstructuur is onafhankelijk van de a priori kans. Dit betekent dat bij de bepaling van het optimale afkappunt volgens deze methode geen rekening wordt gehouden met de hoogte van de a priori kans, zoals dat bijvoorbeeld het geval is bij het predictieve waarde model (zie hiervoor).

Bij de entropie-benadering gelden deze lineaire relaties niet. Worden de isoquantencurves geconstrueerd dan blijken deze een concaaf verloop te hebben (Metz e.a., 1973).

Aangezien de informatie-inhoud van een test afhangt wan de a priori kans geldt dat bij iedere a priori kans een bijbehorende reeks iso-informatiecurves is te construeren. Voor de a priori kans van .2 is in figuur $4.6 \mathrm{~b}$ de isoquantenstructuur weergegeven. Over de hier afgebeelde curves kan de ROC-curve worden getekend en op deze wijze wordt duidelijk hoeveel de informatie-inhoud is voor ieder punt op een ROC-curve en tevens bij welk punt de maximale informatie-inhoud wordt bereikt. De methodiek kan ook gebruikt worden als er sprake is van een asymmetrische ROC-curve. 
Figuren $4.6 \mathrm{a}$ en $4.6 \mathrm{~b}$.
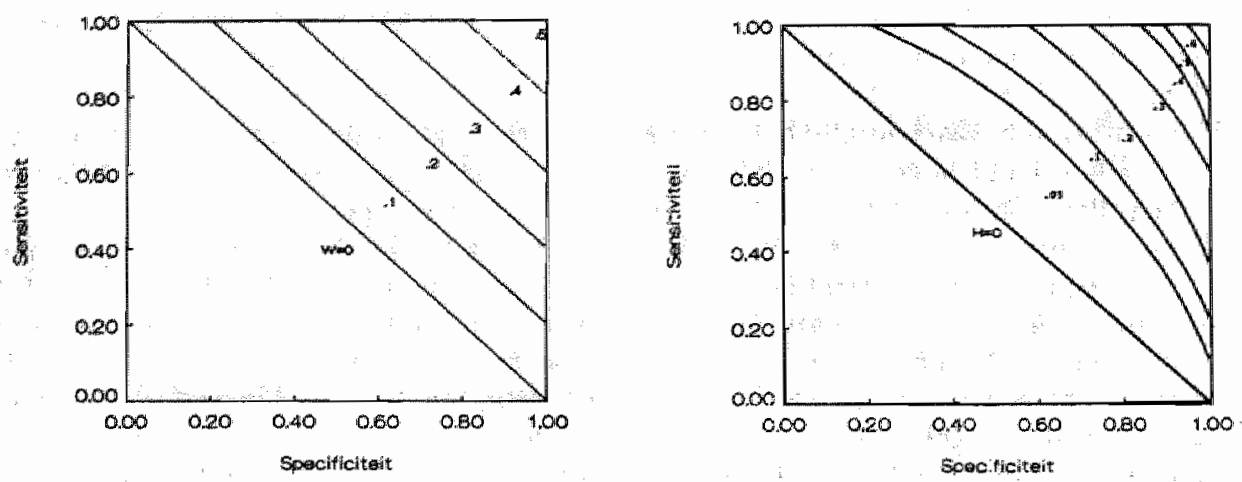

Een waardeloze test ligt in beide methoden op de $45^{\circ}$-lijn en de perfecte test is rechts boven in de figuur gelocaliseerd. Ten opzichte van een waardeloze test worden in de entropie-methode relatief weinig bits aan informatie verkregen bij grote verbeteringen in sensitiviteit en/of specificiteit. In het gegeven voorbeeld dient een bijna perfecte test te worden gebruikt teneinde zo'n $60 \%$ van de maximale opbrengst te behalen. Dit impliceert dat de entropie-methode in het gebied waar veruit de meeste tests zich bevinden zeer ongevoelig meet.

De winst aan informatie is bij de entropie-methode niet gelijk over het gehele scala van waarden van sensitiviteit en specificiteit.

Met andere woorden de bits-schaal is door de rekenkundige bewerking zodanig getransformeerd dat de interpretatie van de resultaten problematisch wordt. Dit is overigens niet zo'n belangrijke tekortkoming, indien er slechts ordinale gevolgtrekkingen aan de berekeningen worden ontleend, bijvoorbeeld

- $\quad$ test A reduceert de onzekerheid meer dan test B doet of

- bij afkappunt $C$ is de winst in zekerheid groter dan bij afkappunt $D$.

Vooral indien de therapeutische consequenties in de beschouwing worden betrokken (zie hoofdstuk 6 en volgende), worden deze tekortkomingen zichtbaar. In dergelijke situaties moet er rekening mee worden gehouden in welk gebied van sensitiviteit en specificiteit de onzekerheidsreductie heeft plaatsgevonden. Dergelijke problemen zijn er niet bij hantering van de formule van Connell \& Koepsell.

\section{De invloed van veranderingen in sensitlviteit en specificiteit}

De logaritmische transformatie heeft een tweede verschil tot gevolg. In de informatietheorie treedt er een verschil op tussen een test met een sensitivileit van .75 en een specificiteit van .95 en een test met een sensitiviteit van .95 en een specificiteit van .75. Bij Connell \& Koepsell leidt dit tot een identiek resultaat (zie figuren 4.5a en 4.5b). 
Ook dit verschil wordt veroorzaakt door de logaritmische transformatie van de opbrengsten, waardoor bij een prevalentie lager dan .5 een test met een hogere specificiteit een hogere opbrengst vertoont en omgekeerd bij een prevalentie groter dan .5 een test met een hogere sensitiviteit een hogere opbrengst vertoont. In de grafiek met de isoquanten blijkt dit uit de kromming van de lijnen. Bij een a priori kans van .5 zijn de curves symmetrisch. Bij een a priori kans van $.5 \mathrm{t} / \mathrm{m} 1$ zijn de isoquanten zodanig gebogen dat een hoge sensitiviteit belangrijker is dan een hoge specificiteit. Het omgekeerde geldt voor a priori kansen tussen 0 en .5 . In dat geval is een hoge specificiteit belangrijker dan een hoge sensitiviteit. In de informatietheorie wordt dus rekening gehouden met de invloed van de a priori kans. De conclusie die hieruit getrokken kan worden luidt dat in dit opzicht het concept van de entropie te prefereren is boven de methodiek van Connell \& Koepsell.

Samenvattend kunnen de navolgende conclusies worden getrokken.

Om de onzekerheidsreductie ten gevolge van testgebruik weer te geven, kunnen diverse methoden worden gebruikt. Uit de vergelijking van twee methoden (de W-curve en de $\mathrm{H}_{\mathrm{m}}$-curve) resulteren de navolgende verschilpunten:

- de W-curve is minder volledig dan de $\mathrm{H}_{\mathrm{m}}$-curve omdat slechts de onzekerheidsreductie ten gevolge van juiste uitslagen wordt berekend. Bij de $\mathrm{H}_{\mathrm{m}}$ curve worden ook de foute uitslagen meegenomen.

- de entropie-benadering is minder bruikbaar in het kader van evaluatie, waarbij ook de uitkomsten van het zorgproces een rol spelen.

bij de afweging van de sensitiviteit versus de specificiteit van een test dient de a priori kans mede een rol te spelen. Bij Connell en Koepsell blijkt de a priori kans geen rol te spelen ten aanzien van dit keuzeprobleem. Bij het entropieconcept blijkt deze invloed wel aanwezig.

Bovenstaande analyse laat geen eenduidige conclusie toe ten aanzien van de beide methoden. Dit is de reden dat in het volgende hoofdstuk, naast de benadering van Connell \& Koepsell, ook gebruik is gemaakt wan de entropiebenadering om de opbrengst van een aantal teststrategieèn te berekenen. 


\section{BUllage 4.1}

Afleiding formule onzekerheidsreductie van Connell \& Koepsell

$$
\begin{aligned}
& W=P(T+) *[P(D+\mid T+)-P(D+)]+P(T-) *[P(D-\mid T-)-P(D-)] \\
& y=\text { Se.p }+(\mathbb{1}-S p)(1-p)
\end{aligned}
$$

dan is

$1-y=S p(1-p)+(1-S e) p$

Substitueren voor:

$$
\begin{gathered}
P(D+)=p \\
P\left(D^{-}\right)=1-p
\end{gathered}
$$$$
P(D+\mid T+)=\frac{\text { Se.p }}{\text { Se.p }+(1-S p)(1-p)}=\frac{\text { Se.p }}{y}
$$

$$
P(D-\mid T-)=\frac{S p(1-p)}{S p(1-p)+(1-S e) p}=\frac{S p(1-p)}{1-y}
$$

$$
\begin{aligned}
& P(T+)=\operatorname{Se} . p+(1-S p)(1-p)=y \\
& P(T-)=1 \cdot(\text { Se.p }+(1-S p)(1-p))=1-y \\
& W=y\left(\frac{S e . p}{y}-p\right)+(1-y)\left(\frac{S p(1-p)}{(1-y)}-(1-p)\right)
\end{aligned}
$$


$\mathrm{W}=\mathrm{Se} . \mathrm{p}-\mathrm{yp}+\mathrm{Sp}(1-\mathrm{p})-(1-\mathrm{y})(1-\mathrm{p})$

$W=S e \cdot p+S p-S P \cdot p-1+p+y(-2 p+1)$

Substitutie van y en vereenvoudiging levert:

$W=2 p(S e-S e . p-1+p+S p-S p \cdot p)$

ofwel

$\mathrm{W}=2 \mathrm{p}(1-\mathrm{p})(\mathrm{Se}+\mathrm{Sp}-1)$ 


\section{Bijlage 2}

Voor de berekening van de mutuele entropie, behaald door uitvoering van een test is gebruik gemaakt van de navolgende methode, vermeld in Büttner (1977). De methodiek gaat uit van $m$ ziekte categorieên en $n$ testuitslagen.

De algemene formule, waarmee in een dergelijke situatie de winst in informatie ofwel de mutuele entropie kan worden bepaald luidt:

$$
H_{m}=H_{\text {pre }}-H_{\text {post }}=\sum_{i=1}^{m} \sum_{j=1}^{n} p_{i j}{ }^{2} \log \frac{p_{i j}}{p_{i} \cdot p_{j}}
$$

waarbij geldt dat $p_{b}$ de kans is op ziektecategorie $i$ in de testuitslag $j$ (hier wordt de betreffende kans uitgedrukt in het totaal),

zodat geldt:

$$
\sum_{i=1}^{m} \sum_{j=1}^{n} p_{i j}=1
$$

Verder geldt dat:

$$
p_{t}=\sum_{j=1}^{n} p_{i j}
$$

en

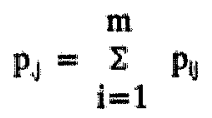

Bovenstaande formule kan als volgt afgeleid worden uit de formules (4.13) en (4.14).

$\mathrm{H}_{\mathrm{m}}=\mathrm{H}_{\text {pre }}-\mathrm{H}_{\text {post }}$ 
Deze formule kan als volgt afgeleid worden van de formules (4.13) en (4.14).

$$
\begin{aligned}
& H_{m}=\sum_{i} P\left(D_{i}\right)^{2} \log \frac{1}{P\left(D_{i}\right)}-\sum_{j} P\left(T_{j}\right) \sum_{i} P\left(D_{i} \mid T_{j}\right)^{2} \log \frac{1}{P\left(D_{i} \mid T_{j}\right)} \\
& =\sum_{i} \sum_{j} P\left(D_{i}, T_{j}\right)^{2} \log \frac{1}{P\left(D_{i}\right)}-\underset{i}{\sum} \sum_{j} P\left(D_{i}, T_{j}\right)^{2} \log \frac{1}{P\left(D_{i} / T_{j}\right)} \\
& =\underset{i \text { i j }}{\sum \sum\left(D_{i}, T_{i}\right)}{ }^{2} \log \frac{P\left(D_{i} \mid T_{j}\right)}{P\left(D_{i}\right)} \\
& =\sum_{i j} \sum_{j} P\left(D_{i}, T_{j}\right){ }^{2} \log \frac{P\left(D_{i}, T_{j}\right)}{P\left(D_{i}\right) \times P\left(T_{j}\right)}
\end{aligned}
$$

Toepassing van deze formule betekent een vereenvoudiging van de rekenprocedure. Ter illustratie volgt hier een berekening van de mutuele entropie van een test met sensitiviteit van .836 en een specificiteit van .840 bij een a priori kans van .1. In de onderstaande tabel staan de respectievelijke kansen $p_{i j}, p_{h}$ en $p_{j}$.

$$
D+\quad D
$$

\begin{tabular}{llll}
$\mathrm{T}+$ & $\mathrm{p}_{11}=.0836$ & $\mathrm{p}_{21}=.1440$ & $\mathrm{p}_{.1}=.2276$ \\
$\mathrm{~T}-$ & $\mathrm{p}_{12}=.0164$ & $\mathrm{p}_{22}=.7560$ & $\mathrm{p}_{.2}=.7724$ \\
\hline & $\mathrm{p}_{1 .}=.1$ & $\mathrm{p}_{2}=.9$ & 1
\end{tabular}

Bepaling van $p_{i j} \cdot{ }^{2} \log \frac{p_{i}}{p_{L} \cdot p_{j}}$ levert op: 
$\mathrm{T}+$

$.1569 \quad-.0732$

T.

$-.0367: \quad .0915$

Het aardige van deze methode is dat duidelijk wordt hoeveel bit aan informatie gewonnen wordt in de respectievelijke categorieën. Terechte uitslagen voegen hier iets aan toe, foute uitslagen werken tegengesteld.

De totale winst in bits tengevolge van de test bedraagt:

$(.1569-.0732-.0367+.0915)=.1385$ 


\section{KOSTEN-EFFECTIVITEITSANALYSE VAN TESTSTRATEGIEEN: een procesbenadering ${ }^{1}$}

\subsection{INLEIDING}

In het voorgaande hoofdstuk is gebleken dat de opbrengst van een test kan worden gemeten met behulp van de formule van Shannon, of onder andere met de formulle van Connell \& Koepsell. In dit hoofdstuk wordt een toepassing van deze concepten beschreven in een testsituatie, waarbij er sprake is van twee tests, en waarbij meerdere teststrategieën kunnen worden gevolgd. Bij de evaluatie van teststrategieèn worden bovendien de kosten betrokken. Het voorbeeld, waarop de berekeningen zijn gebaseerd, is ontleend aan het boek "Beyond Normality" van Galen \& Gambino (1975). In dit voorbeeld gaat het om twee onafhankelijke tests, welke op drie verschillende manieren kunnen worden toegepast.

Men kan allereerst gebruik maken van een test, test A (strategie a) of test B (strategie b).

In de tweede plaats kan men voor een seriebenadering opteren. In dit voorbeeld gaan wij ervan uit (conform de aannamen van Galen \& Gambino) dat daarbij zowel test $A$ als test $B$ positief moeten zijn, alvorens men aanneemt dat de ziekte aanwezig is. Hierbij maakt het voor wat betreft de kosten wel uit of men eerst $A$ en daarna $B$ uitvoert (alternatief $c$ ) of eerst $B$ en daarna $A$ (alternatief $d$ ).

In de derde benadering wordt een zgn. parallel-benadering toegepast. De ziekte wordt aanwezig geacht indien of test $A$ en $B$ positief zijn of alleen test $A$ of alleen test $B$. Deze laatste strategie wordt hieronder aangeduid als strategie $e$. (Het is overigens mogelijk om zowel voor de serie- als parallel-test een ander positiviteitscriterium te hanteren dan het hier veronderstelde, zie hoofdstuk 8. De onderstaande conclusies hebben betrekking op de tests met de positiviteitscriteria zoals boven gedefinieerd.) In onderstaande tabel zijn de sensitiviteit en de specificiteit van de diverse alternatieven vermeld. De auteurs berekenen met behulp van $2 \times 2$ tabellen voor een a priori kans van .01 de beste strategie. Impliciet veronderstellen zij dat de twee tests even duur zijn. De conclusies die de auteurs trekken luiden als volgt:

I De parallel-test heeft de hoogste sensitiviteit en de laagste specificiteit, terwijl de serie-test de laagste sensitiviteit en de hoogste specificiteit heeft.

II Beide serie-tests leiden uiteindelijk tot hetzelfde aantal opgespoorde ziektegevallen. Indien eerst de test met de hoogste specificiteit wordt gekozen, dan zijn er in de tweede ronde minder tests nodig dan omgekeerd. In bovenstaande termen: strategie $d$ is beter dan strategie $c$.

III De parallel-test leidt tot de hoogste laboratoriumkosten.

In dit hoofdstuk wordt nagegaan in hoeverre bovenstaande conclusies algemene geldigheid hebben. Daartoe wordt met name de invloed van de prevalentie en de invloed van testkosten nagegaan. De berekeningen zullen bovendien zowel met behulp 
van de formules van Shannon alls ook met dje van Connell \& Koepsell worden uitgevoerd.

\subsection{RESULTATEN}

In onderstaande tabel is per strategie berekend hoe groot de opbrengst is in eenheden $H_{m}$ als ook in eenheden $W$.

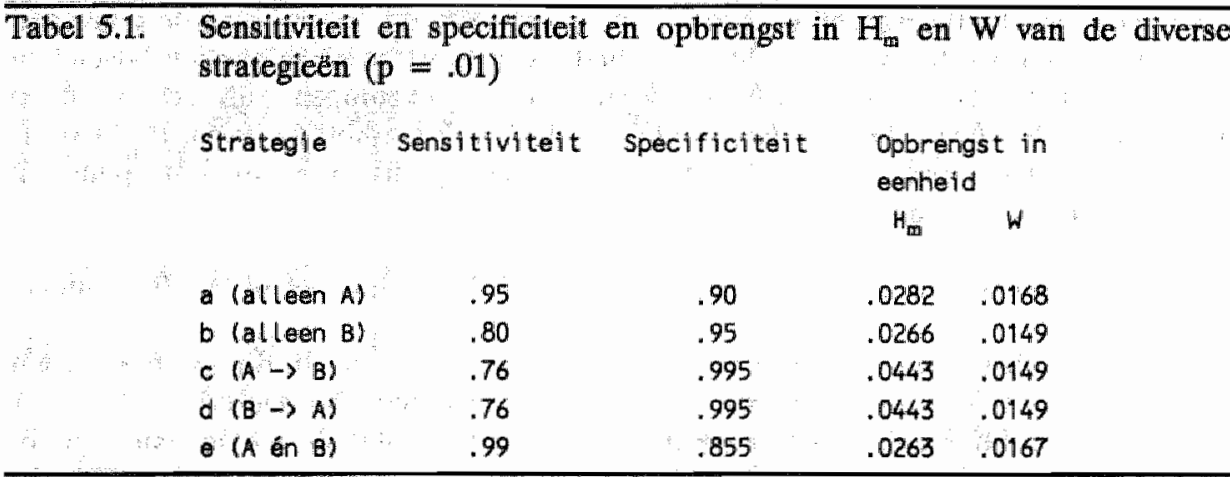

De beide methoden leiden tot verschillende uitkomsten. In bits gemeten blijken de beide seriebenaderingen de hoogste opbrengst te wertonen, terwijl, uitgedrukt in eenheden $W$, a en e de betere strategieän zijn. Deze strategieën worden gekenmerkt door een hoge som van sensitiviteit en specificiteit.

Met behulp van de isoquantenlijnen (zie hoofdstuk 4 ) is op envoudige wijze aan te tonen dat strategie a en e bij Connell \& Koepsell tot de hoogste opbrengst leiden. Dit volgt overigens ook rechtstreeks uit de formule waarmee de opbrengst in $W$ wordt berekend. De isoquantenlijnen worden bij de formule van Shannon door de lage prevalentie op een zodanige wijze gedeformeerd, dat de strategieën $c$ en $d$ op de hoogste iso-informatiecurve komen te liggen.

Opvallend is verder dat in bits gemeten de parallel-benadering tot een geringere opbrengst leidt dan het uitwoeren van een enkele test. Het verlies aan opbrengst ten gevolge van de lagere specificiteit wordt bij deze lage prevalentie niet gecompenseerd door de hogere opbrengst ten gevolge van de hogere sensitiviteit.

Uit de tabel blijkt verder dat geen enkele test of testcombinatie in staat is de bestaande onzekerheid in aanziemlijke mate te reduceren. De beste combinatie slaagt er nog niet in de onzekerheid in bits gemeten met $5 \%$ te verminderen. Bij een a priori kans van .01 bedraagt de mutuele entropie van een test met sensitiviteit en specificiteit van Gén slechts .080642. Uitgedrukt als percentage van de maximaal haalbare opbrengst bij $p$ $=.01$ is de winst (behaald in de beste strategie) echter aanzienlijk: $54,9 \%$.

Voor W is de maximaal haalbare opbrengst slechts .0198, bij een prevalentie van .01, zodat de relatieve winst van de beste test $84,5 \%$ is.

Verder blijkt dat het niet mogelijk is op basis van de gegevens uit de tabel te bepalen welke volgorde van tests binnen de serie-teststrategie de beste is. Daartoe ontbreken vooralsnog de efficiency-criteria in de analyse (zie paragraaf 5.3). 
Een belangrijke vraag is verder in hoeverre de verkregen uitkomsten afhankelijk zijn van de tot nu toe aangenomen a priori kans van .01 . Daartoe zijn de berekeningen voor beide methoden herhaald voor alle waarden van a priori kansen gelegen tussen nul en éen. De opbrengst is uitgedrukt als een percentage van de maximaal halbare opbrengst, waarvan de hoogte in sterke mate afhangt van de a priori kans.

Figuur 5.1. Hm als percentage van maximaal te behalen aantal bits

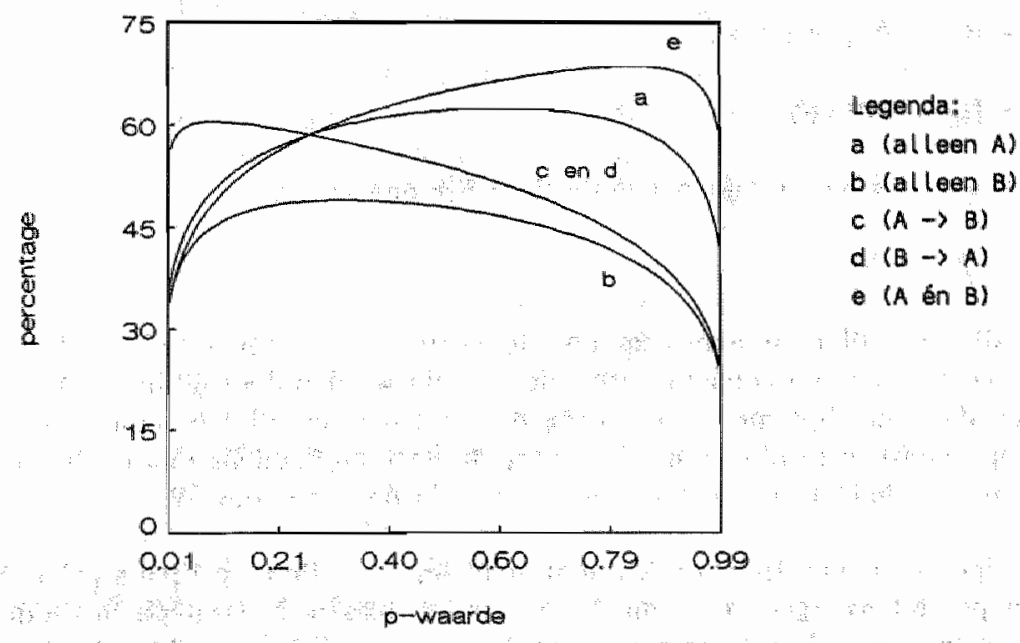

Het blijkt nu dat de conclusies, die hierboven getrokken werden met betrekking tot het beste alternatief bij de entropie-benadering slechts gelden voor bepaalde waarden van a priori kansen. Globaal geldt dat de seriecombinatie de beste strategie is, indien de a priori kans kleiner is dan .25 , daarboven geeft de parallel-combinatie de hoogste opbrengst. Hoe hoger de a priori kans des te slechter wordt de seriecombinatie, een gevolg van de lage sensitiviteit van deze testcombinatie. Test $B$ is in feite altijd inferieur.

Bij de opbrengst, gemeten op de wijze zoals Connell \& Koepsell dit voorstellen, is de optimale strategie volledig onafhankelijk van de a priori kans, zoals uit hoofdstuk 4 reeds bleek. Alle teststrategieèn behalen een bepaald percentage van de maximaal te behalen opbrengst en dit percentage blijft constant voor alle waarden van a priori kansen.

De percentages bedragen voor de vijf teststrategieën a $\mathrm{t} / \mathrm{m}$ e respectievelijk $85,0 \%$, $75,0 \%, 75,5 \%, 75,5 \%$ en $84 \%$.

\subsection{KOSTEN PER OPBRENGST}

Tot nu toe is in feite alleen gekeken naar de opbrengst van teststrategieen (hoeveel eenheden $\mathrm{H}$ of $\mathrm{W}$ kan de test of testcombinatie produceren?) en niet naar de kosten van de test(strategieën). In de onderstaande analyse worden ook kostenoverwegingen in de beschouwing betrokken. Zeker in een situatie zoals in de gezondheidszorg, waarbij 
steeds meer gewerk dient te worden op basis van een beperkt budget, dienen bij het bepalen van optimale teststrategieën ook kostenoverwegingen een rol te spelen.

In cerste instantie wordt verondersteld, dat de kosten van test $A$ en test $B$ gelijk zijn aan elkaar $\left(\mathrm{K}_{\mathrm{a}}=\mathrm{K}_{\mathrm{b}}\right)$. De kosten van strategie $c$ wijken af van strategie $\mathrm{d}$, waardoor het mogelijk wordt de beide serie-tests op hun efficiency te beoordelen. De kosten van beide strategieen c en d zijn overigens gemakkelijk te bepalen. De kosten van strategie c zijn de kosten van test A plus de kosten van test $B$ in die gevallen, waarin test $A$ positief is:

$$
\begin{aligned}
& \mathrm{K}_{\mathrm{c}}=\mathrm{K}_{\mathrm{A}}+\mathrm{P}\left(\mathrm{T}_{\mathrm{A}}+\right) * \mathrm{~K}_{\mathrm{B}} \\
& \mathrm{K}_{\mathrm{d}}=\mathrm{K}_{\mathrm{B}}+\mathrm{P}\left(\mathrm{T}_{\mathrm{B}}+\right) * \mathrm{~K}_{\mathrm{A}}
\end{aligned}
$$

De kosten van strategie e zijn per definitie gelijk aan:

$$
K_{e}=K_{A}+K_{\sharp}
$$

$\mathrm{Nu}$ zijn alle ingrediënten aanwezig om de kosten-effectiviteitsratio's te berekenen. Indien de kosten van een bepaalde strategie gedeeld worden door de opbrengst van het alternatief, dan verkrijgt men het bedrag dat in dat alternatief benodigd is om éen eenheid opbrengst te produceren. Hoe lager de kosten-effectiviteitsratio des te beter. Als opbrengsteenheid kan gekozen worden voor $\mathrm{H}$ dan wel voor $\mathrm{W}$.

In de navolgende figuur zijn voor de vijf strategieën voor alle mogelijke a priori kansen de kosten per bit weergegeven. Om de verschillen tussen de strategieën duidelijk te kunnen aangeven is gekozen voor een weergave op een logaritmische schaal.

Figuur 5.2. Kosten per bit ( $\mathrm{Hm})$ (logaritmisch)

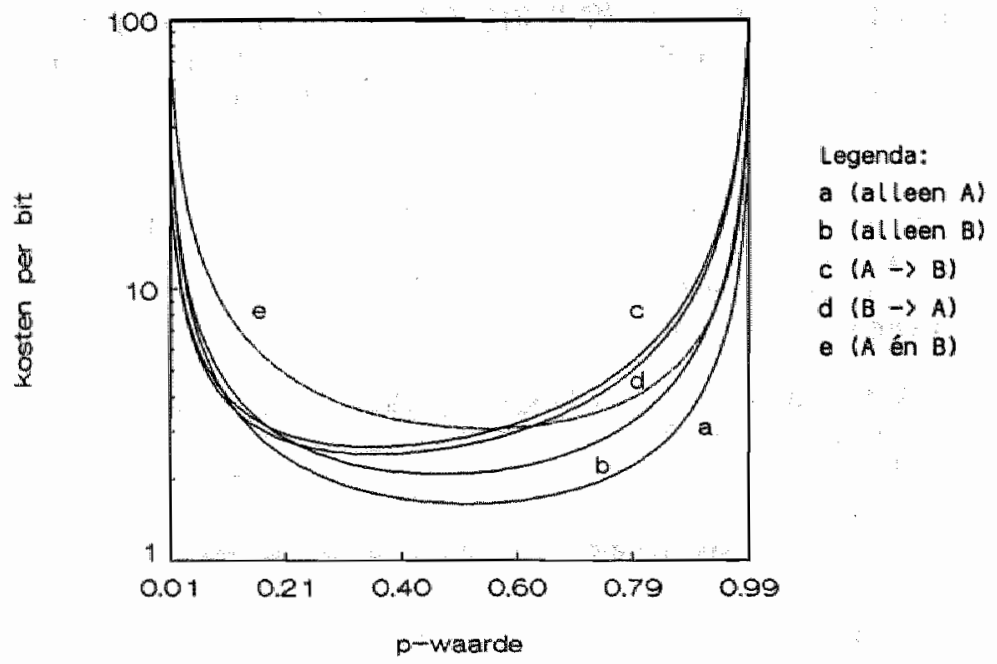

Uiteraard is deze grafiek globaal gesproken een spiegeling van de grafiek, waar alleen de opbrengsten in bits staan vermeld (zie voorgaande grafiek). Daar waar de 
opbrengsten relatief laag zijn (bij zeer lage en zeer hoge a priori kansen) zijn de kosten per bit relatief hoog. Het omgekeerde geldt voor a priori kansen van \pm .5 . Interessanter is om na te gaan wat de meest optimale strategie is bij de verschillende a priori waarden. Laten we eerst de enkele tests bekijken (strategie a en b). Bij zeer lage a priori kansen zijn de beide strategieën praktisch gelijkwaardig. Bij hogere a priori kansen wordt test $\mathrm{A}$ echter beter, hetgeen uitsluitend veroorzaakt kan worden door de hogere opbrengsten (in bits).

Bij lage waarden voor a priori kansen $(\mathrm{p}<.13$ ) wormt de serie-strategie het meest kosten-effectieve allernatief.

De serie-tests (strategie $c$ en d) zijn over het hele spectrum van a priori kansen praktisch gelijkwaardig aan elkaar, waarbij strategie d steeds iets kosten-effectiever is. Van deze beide alternatieven zijn de opbrengsten gelijk, zoals we boven gezien hebben, maar de kosten verschillend, ten gevolge van het feit dat de testcombinaties verschillende aantallen positieve testuitslagen opleveren. De conclusie die hiervóor getrokken is in verband met de volgorde van tests bij serie-testen is dus well te veralgemeniseren wat betreft de a priori kans. Wanneer de kosten van de tests even groot zijn, is strategie $\mathrm{c}$ beter dan strategie $\mathrm{d}$, indien geldt:

$$
\mathrm{P}\left(\mathrm{T}_{\mathrm{A}}+\right)<\mathrm{P}\left(\mathrm{T}_{\mathrm{B}}+\right)
$$

Hieruit kan worden afgeleid dat indien geldt:

$$
\mathrm{p}<\frac{S p^{A}-S p^{B}}{S e^{A}-S e^{B}+S p^{A}-S p^{B}} \text { (indien noemer positief) }
$$

eerst test A uitgevoerd dient te worden, gevolgd door test $\mathrm{B}$. Zo niet, dan dient de volgorde omgedraaid te worden.

De optimale volgorde bij serie-testen, wordt dus niet uitsluitend bepaald door de specificiteit van de respectievelijke tests, maar evenzeer door de sensitiviteit.

De conclusie van Galen \& Gambino met betrekking tot de optimale volgorde bij het testen in serie is juist in het gegeven cijfervoorbeeld. Voor andere situaties kan met behulp van bovenstaande formule de optimale vollgorde worden bepaald, waarbij dan overigens nog de veronderstelling geldt dat de testkosten gelijk zijn.

De parallel-test tenslotte is bij zeer lage waarde van $p$ relatief duur en is voor relatief hoge waarde van $\mathrm{p}$ een redelijk kosten-effectief alternatief. De relatief hoge kosten van dit alternatief worden dus blijkbaar in die situatie gecompenseerd door de relatief hoge opbrengsten.

Zijn de kosten van test $A$ en test $B$ gelijk aan elkaar en wordt de opbrengst bepaald via de formule van Connell \& Koepsell, dan is alleen test $A$ uitvoeren de strategie met de laagste kosten-opbrengsten verhouding over het gehele spectrum van a priori kansen (zie figuur 5.3). 
Figuur 5.3. Kosten per opbrengst (W) (logaritmisch)

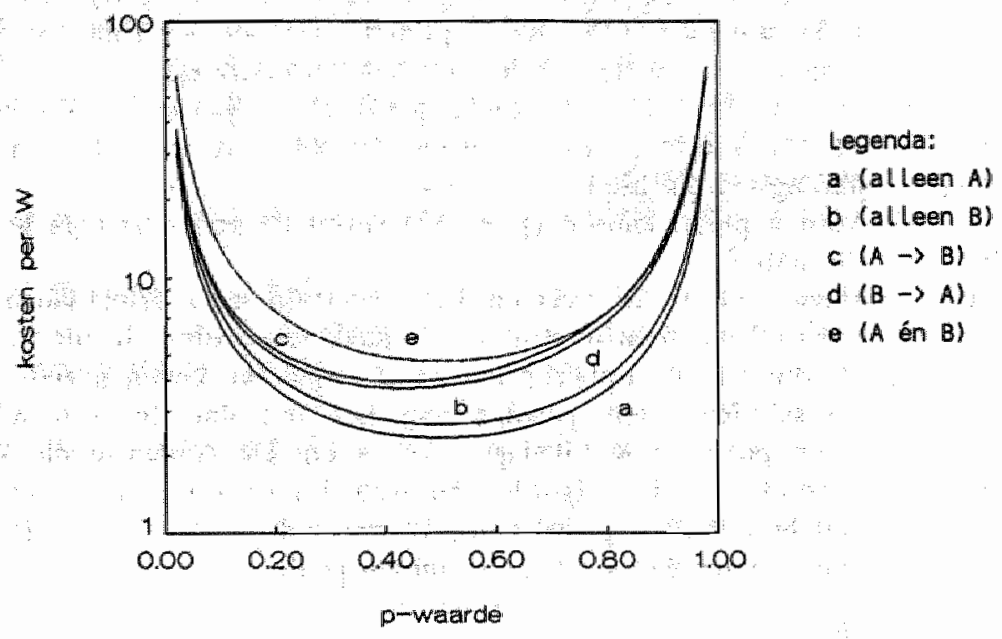

Bij de vergelijking van serie-tests onderling blijkt eerst uitvoeren van test $B$ kosteneffectiever dan eerst uitvoeren van A, bij iedere waarde voor de a priori kansen. Dezelfde conclusie is hiervoor getrokken, waar de opbrengst in bits werd uitgedrukt. $\mathrm{Er}$ is echter cen verschil. Indien de opbrengst in eenheden $\mathrm{H}$ worden uitgedrukt, is de serie-benadering het meest kosten-effectief voor $\mathrm{p}$-waarden tot \pm .13 , terwijl bij het uitdrukken van de opbrengsten in eenheden $W$ het alleen uitvoeren van een test ook bij lage prevalentie de voorkeur heeft. Ook dit wordt veroorzaakt doordat in de opbrengsteneenheid "bit" op cen speciale wijze rekening wordt gehouden met sensitiviteit en specificiteit van de test, waardoor bij lage prevalenties het belang van de specificiteit relatief groot is.

Overigens dient men te bedenken, dat deze conclusies gelden onder de veronderstelling dat de sensitiviteit en specificiteit van zowel test A als test B gegeven zijn en dat de kosten van test A gelijk zijn aan de kosten van test B. In de navolgende paragraaf is de invloed van veranderingen in de kostenverhouding nagegaan.

\subsection{INVLOED KOSTENVERHOUDING}

In de wolgende analyse wordt nagegaan wat de invloed is van de kosten van test $A$ en test B. Daartoe zullen berekeningen worden gemaakt waarbij test A relatief goedkoop is ten opzichte van test B en berekeningen waarbij test A relatief duur is ten opzichte van test $B$. Als alternatieven worden in deze analyse een kostenverhouding van $K_{A}: K_{B}$ van $1: 8$ en een verhouding van $8: 1$ als uitersten nader bekeken. Overigens zijn dit slechts willekeurig gekozen grenzen, die naar believen gevarieerd kunnen worden. In eerste instantie wordt uitgegaan van een a priori kans van .1. Onderstaande figuur bevat de resulltaten. 
Figuur 5.4. Kosten per bit naar kostenverhouding test A en B

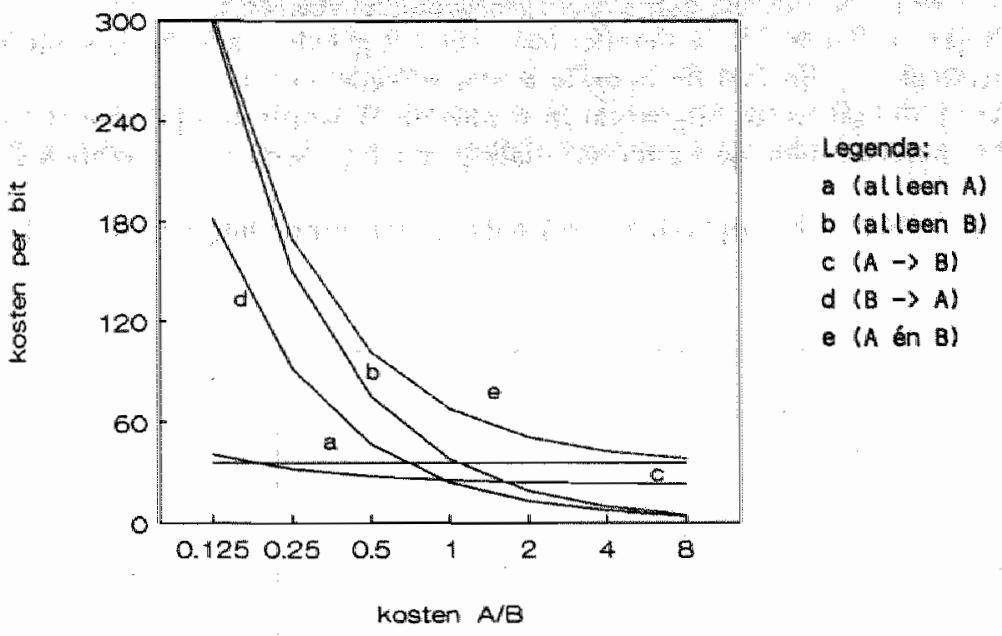

In de analyse zijn de kosten van test $A$ constant verondersteld en variëren de kosten van test B. Per definitie verloopt de lijn, met de kosten per bit wan strategie a horizontaal.

De beste strategie blijkt sterk afhankelijk te zijn van de kostenverhouding. Indien de kosten van test $\mathrm{A}$ geringer zijn dan de kosten van test $\mathrm{B}$ is alleen uitvoeren van test $\mathrm{A}$ beter dan alleen uitvoeren van test $B$. Ook in de vergelijking van de beide seriebenaderingen blijkt de hoogte van de testkosten vam doorslaggevende betekenis. Is test A duurder dan test $B$, dan is eerst uitvoeren van test $B$ en daarna test $A$ de betere strategie. Indien test A goedkoper is, dient de volgorde omgedraaid te worden. Stellen we de kosten van test A op 1, en drukken we de kosten van test B uit in een verhoudingsgetal ten opzichte van de kosten van test $A$, dan kan, op dezelfde wijze als hiervoor, worden afgeleid dat strategie $c$ beter is dan $d$, indien geldt:

$$
\mathrm{p}<\frac{\mathrm{K}_{\mathrm{B}} S \mathrm{Sp}^{\mathrm{A}}-\mathrm{Sp}^{\mathrm{B}}}{S \mathrm{Se}^{\mathrm{A}}-\mathrm{Se}^{\mathrm{B}}+\mathrm{K}_{\mathrm{B}} S \mathrm{Sp}^{\mathrm{A}}-S \mathrm{P}^{\mathrm{B}}-\mathrm{K}_{\mathrm{B}}+1}
$$

(indien noemer positief)

Voor $K_{B}=K_{A}=1$, is deze formule gelijk aan voorgaande formule.

Vergelijken we de kosten-effectiviteit van de serie-test met de enkele test dan kan de volgende conclusie worden getrokken. Een serie-strategie is kosten-effectiever dan het uitvoeren van een enkele test. Dit geldt in het gegeven voorbeeld voor bijna alle beschouwde kostenverhoudingen. Slechts indien de kosten van test $A$ zeer gering zijn ten opzichte van test $B$, is uitvoeren van test $A$ alleen de beste strategie. De conclusies van Galen \& Gambino over de meest optimale volgorde van serie-tests kan van enkele kanttekeningen worden voorzien. De kostenverhouding blijkt van veel groter betekenis dan de specificiteit. Hiervóór (zie par. 5.3) concludeerden we reeds dat ook de hoogte van de a priori kans een belangrijke factor vormt. In paragraaf 5.5 zullen de 
veranderingen in de beide factoren (kostenverhowding en a priori kans) gelijktijdig onderzocht worden, middels een tweeweg gevoeligheidsanalyse.

Verder blijkt uit figuur 5.4 de parallel-test cver het gehele scala van kostenverhoudingen de strategie te zijn mel de hoogste kosten-effectiviteitratio.

Indien de opbrengst wordt uitgedrukt in eenheden W wordt de optimale strategie nog duidelijker bepaald door de kostenverhouding van test A en B (zie grafiek 5.5).

Figuur 5.5. Kosten per opbrengst (W) naar kostenverhouding test A en B

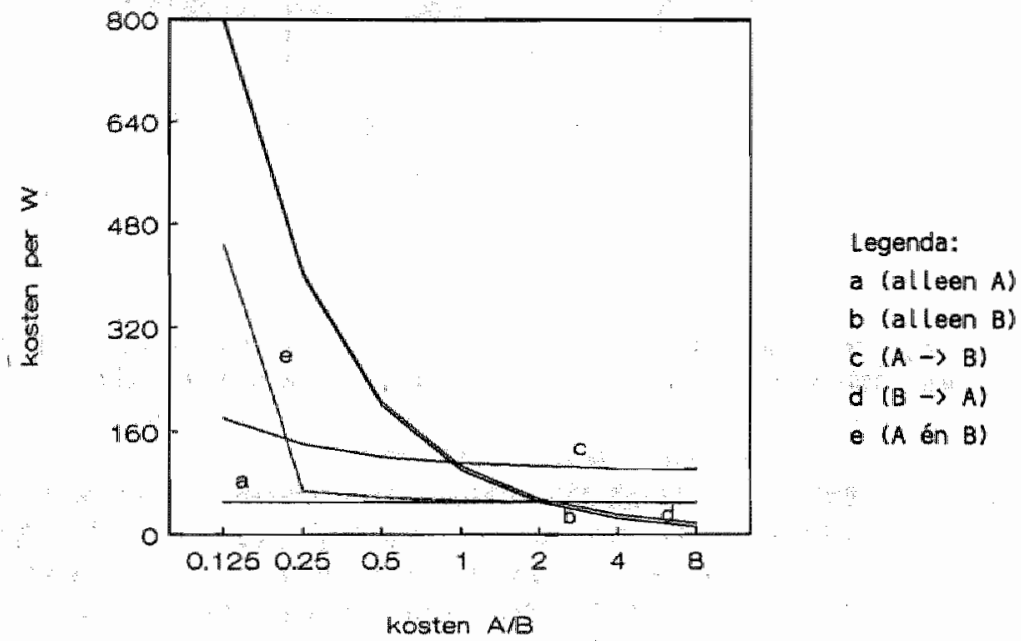

Serie- noch parallel-tests vormen een kosten-effectief alternatief voor het apart uitvoeren van test $A$ of $B$. Of gekozen moet worden voor alleen test $A$ of alleen test $B$ als meest kosten-effectieve strategie wordt praktisch volledig bepaald in dit geval (bij deze sensitiviteit en specificiteit en a priori kans) door de hoogte van de testkosten. Door de hogere opbrengst van test $A$ kan test $A$ tweemaal zo duur zijn als test $B$, voordat test $B$ het betere alternatief wordt.

\subsection{INVLOED VAN DE A PRIORI KANS EN DE KOSTENVERHOUDING}

Alle tot nu toe getrokken conclusies gelden onder aanname van de a priori kans van $p=.01$. Hieronder zal de analyse uitgebreid worden tot het gehele spectrum van p-waarden, waarbij tevens de kosten mogen varieren over het hele aangegeven spectrum. In figuur 5.6 staat het eindresultaat voor de entropie-benadering.

De figuur is een uitbreiding van de figuur 5.3 en 5.4 . De stippellijnen geven aan waar de voorgaande figuren geplaatst kunnen worden. Het kruispunt van de stippellijnen geeft de situatie aan waarvan Galen \& Gambino in hun rekenvoorbeeld zijn uitgegaan. 
Het is niet langer mogelijk alle strategieen vergelijkendenwijs in de grafiek te presenteren. Alleen de optimale strategie is weergegeven bij iedere combinatie van variabelen.

Figuur 5.6, Optimale teststrategie bij willekeurige kostenverhouding en a priori kans

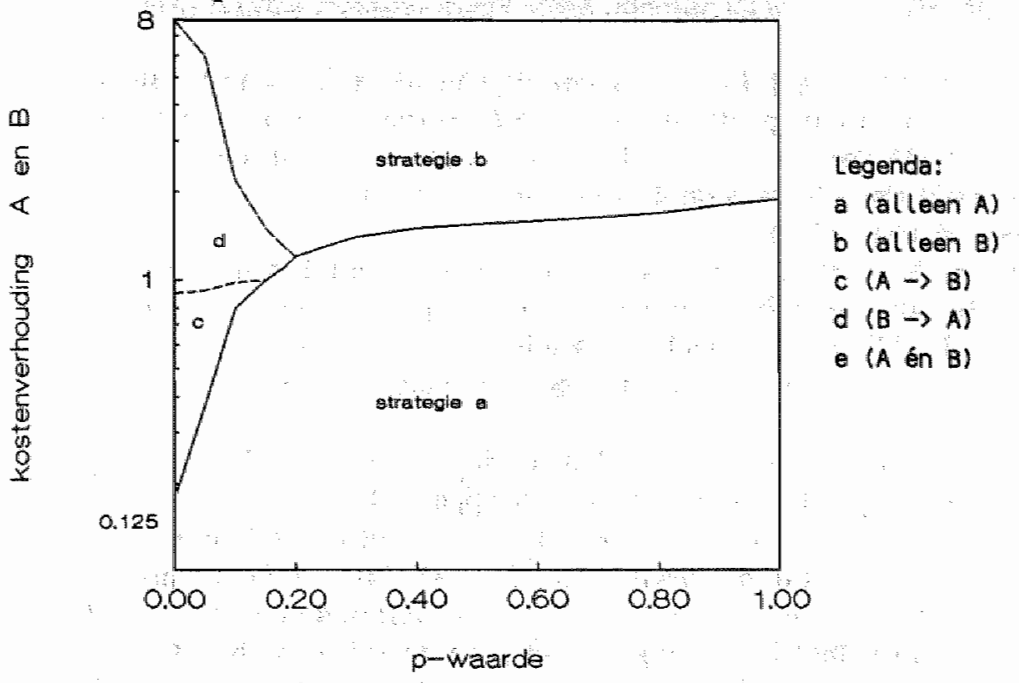

Het meest opvallende resultaat van bovenstaande analyse is thet feit dat het uitvoeren van parallel-testen in het onderzochte gebied nooit een kosten-effectieve strategie genoemd kan worden. Alle overige vier strategieën zijn dat wel bij bepaalde combinaties van kostenverhouding en a priori kans.

Globaal kan men het resultaat als volgt samenvatten; Indien de kosten van test $A$ hoger zijn dan van test $B$ is test $B$ kosten-effectiever dan A (en omgekeerd). Dit resultaat wordt overigens mede bepaald door de sensitiviteit en de specificiteit van de testen $A$ en $B$, zoals die in dit voorbeeld gelden. Verder geldt dat in een bepaald gedeelte waar test $B$ te prefereren is boven test $A$ de seriebenadering $\mathbb{d}$ (eerst $B$ dan $A$ ) te verkiezen is boven alleen uitvoeren van test $B$. Dit is met name het geval indien de a priori kans laag is. Hetzelfde geldt woor het gebied waar test A te prefereren is. Hier geldt ook dat een seriebenadering te prefereren is boven test $B$ met name indien de a priori kans laag is (en de kosten van test A en B elkaar niet veel ontlopen).

Eenzelfde figuur kan geconstrueerd worden wanneer de opbrengsten in eenheden $W$ worden uitgedrukt. Het blijkt nu dat voor de betreffende sensitiviteit en specificiteit van tests in het gehele gebied van a priori kansen en in het gehele gebied van kostenverhouding het apart uitvoeren van tests de meest kosteneffectieve strategieên zijn. Welke test de meest optimale strategie is, hangt bij deze opbrengstmaatstaf met name af van de kosten. 


\subsection{SAMENVATTING EN CONCLUSIES}

We zijn uitgegaan van een rekenvoorbeeld ontleend aan het klassieke boek van Galen \& Cambino "Beyond Normality" om een tweetal manieren voor het meten van testopbrengst te illustreren. De ene manier is gebaseerd op de entropie-maatstaf, de andere op een methode ontleend aan Connell \& Koepsell. De analyse omvat het gehele scala van a priori kansen. Het oorspronkelijke rekenvoorbeeld is verder uitgebreid tot een kostenanalyse door verschillende kostenverhoudingen van de twee tests te introduceren.

Galen \& Gambino leggen in hun analyse de nadruk op het verschil tussen a posteriori en a priori kans. In feite geeft dit verschil ook informatie over de mate van onzekerheid (en de eventuele reductie hierin). Een test zorgt ervoor dat aan de ene kant (bij een positieve testuitslag) de kans op de ziekte toeneemt en aan de andere kant afneemt (bij een negatieve testuitslag).

Op grond van bovenstaande analyse kunnen enkele kanttekeningen worden gemaakt bij de conclusie van Galen \& Gambino (zie eerste pagina van dit hoofdstuk).

Conclusie I blijkt bij nadere analyse het gevolg van het gehanteerde positiviteitscriterium. Dit is dus zeker geen algemene conclusie (zie verder hoofdstuk 8).

Over de efficiency van de serie-benadering (conclusie II) kan op grond van bovenstaande analyse het volgende worden opgemerkt.

Het is niet zo, dat de optimale volgorde bij een serie-test louter en alleen bepaald wordt door de hoogte van de specificiteit. Doordat Galen \& Gambino een lage a priori kans als uitgangspunt nemen, evenals een kostenverhouding van éen, is hun conclusie overigens wel juist met betrekking tot het gegeven rekenvoorbeeld. Voor het bepalen van de optimale volgorde bij een seriebenadering dient naast de specificiteit, ook de sensitiviteit, de kostenverhouding van de tests en tenslotte de a priori kans bekend te zijn.

Conclusie III wordt zonder meer bevestigd in bovenstaande analyse. Het parallel uitvoeren van tests leidt tot de hoogste testkosten. Voor het verrichten van een parallel-test moeten dus andere overwegingen een rol spelen, bijwoorbeeld de tijdsfactor binnen welke de informatie beschikbaar moet zijn. Aan de andere kant is het in de praktijk vaak zo dat parallel uitvoeren van tests tot besparing op de productiekosten leidt, zodat de kosten van de parallelstrategie niet langer gelijk is aan de som van de afzonderlijke kosten van de tests.

Belangrijker dan de vergelijking van de uitkomsten van beide methoden $\left(\mathrm{H}_{\mathrm{m}}\right.$ en W) is de vraag welke van deze methoden de voorkeur verdient voor de evaluatie van het diagnostisch proces.

Hiervoor zijn reeds verschillen tussen de beide methoden benoemd. Uit deze rekenvoorbeelden is duidelijk geworden dat deze verschillen aanleiding kunnen geven tot het nemen van verschillende beslissingen bij testgebruik.

Het nadeel van de methode van Connell \& Koepsell is dat bij het selecteren van de beste strategie de a priori kans geen rol speelt ten aanzien van de keuze voor een meer sensitieve dan wel specifieke test. In het voorgaande hoofdstuk is duidelijk gemaakt, dat de a priori kans hierbij wel degelijk van belang is. Bij lage a priori kansen is met name de specificiteit van de test van belang, bij hoge a priori kansen de sensitiviteit. 
Met dit gegeven wordt geen rekening gehouden bij deze methode, hetgeen wel het geval is bij de benadering van Shannon. Op grond hiervan zou deze laatste benadering de voorkeur verdienen.

Een bezwaar van de entropie-benadering is echter dat de opbrengsteenheid "bit" niet gekoppeld kan worden aan therapeutische opbrengsten, welke behaald kunnen worden op grond van de therapie, volgend op het diagnostiseren van de ziekte.

Dit maakt het entropie-concept ongeschikt voor evaluatiedoeleinden waar verdere therapeutische consequenties een rol spelen.

In het volgende hoofdstuk zal uiteengezet worden dat de benadering van Connell \& Koepsell wel zodanig kan worden aangepast dat het eerder genoemde bezwaar ondervangen wordt, en wel zodanig dat de methode bruikbaar is voor een dergelijk uitgebreid evaluatie-perspectief. 


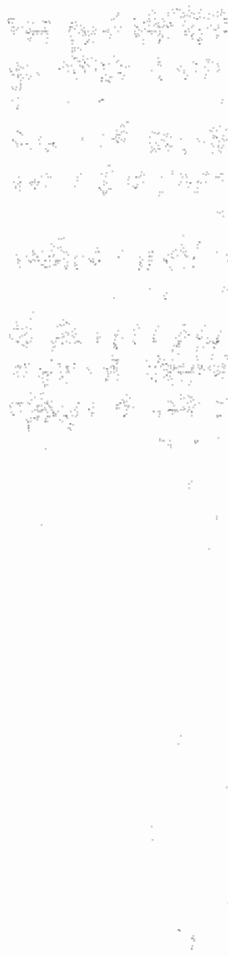




\section{HET OPTIMALE AFKAPPUNT VAN EEN TEST, EEN ECONOMISCHE BENADERING}

\subsection{INLEIDING}

In een economische evaluatie met betrekking tot de inzet van middelen binnen de gezondheidszorg, dient zowel aan de opbrengsten- als aan de kostenkant aandacht geschonken te worden.

\section{Opbrengsten}

De informatie die de test oplevert kan gebruikt worden om beslissingen te onderbouwen, beslissingen die uiteindelijk de gezondheidstoestand van de patient kunnen beïnvloeden.

Verandering in de gezondheidstoestand kan tweeledig worden opgevat: enerzijds kan er sprake zijm van verandering in levensverwachting, anderzijds kan er sprake zijn van veranderingen in het welbevinden van de patiënt: de kwaliteit van leven. In dit hoofdstuk wordt ervan uitgegaan dat het mogelijk is dergelijke veranderingen, zowel wat betreft de sterfte als wat betreft de kwaliteit van leven in een samengestelde maat voor gezondheidswinst uit te drukken: de zogenaamde naar kwaliteit gecorrigeerde levensjaren (Quality Adjusted Life Year, QALY).

Methoden die hierbij gehanteerd kunnen worden zijn de Standard Gamble (SG) en de Time Trade Off (TTO) (zie voor beschrijving van deze methoden Torrance (1976) en Torrance (1986) en voor de toepassing o.a. Ament e.a. (1986).

De uiteindelijke gezondheidswinst wordt behaald na de eventuele behandeling. Echter ook de eventuele negatieve gezondheidseffecten, behorende bij het uitvoeren van een test, vervolgtest en/of behandeling dienen in de evaluatie betrokken te worden.

\section{Kosten}

De kosten van een test kunnen bestaan uit meerdere componenten. In de eerste plaats zijn er de kosten van de middelen, die gebruikt worden om de test te produceren. Deze kosten zijn direct gerelateerd aan de productie van de test. Daarnaast zijn er ook meer indirecte gevolgen wan de test. Een testuitslag kan aanleiding geven tot verdere diagnostiek ten aanzien van een bepaalde aandoening of tot het aanvangen of beeindigen van een therapie. Bij de economische evaluatie van een test zullen naast de kosten van de test zelf, ook afgeleide kosten binnen de gezondheidszorg een rol spelen. Bij de bepaling van de kosten en de opbrengsten van een test gaat het meestal niet om de totale kosten en opbrengsten van een test, maar om verschillen tussen teststrategieên, waarbij in bepaalde situaties verschillende combinaties van tests in varierrende volgorde gehanteerd kunnen worden. Het verschil in kosten tussen verschillende strategieèn kan worden aangeduid met de term: incrementele kosten. Daarnaast speelt het begrip marginaliteit een rol bij de inzet van middelen. Onder marginale kosten worden verstaan de kosten van het produceren van een extra eenheid. Deze kosten zijn meestal lager dan de gemiddelde kosten per test, hetgeen wordt veroorzaakt door het feit dat het overgrote deel van de productiekosten van tests, zoals bijvoorbeeld personeelskosten 
(leiding labotatorium, apparatuur, onderhoud, infrastructuur, etc), kan worden aangemerkt als waste kosten.

In het economische evaluatiemodel wordt gebruik gemaakt van de indeling in terechte en foute, positieve en negatieve testwitslagen (zie hoofdstuk 4). Individuen bij wie een laboratoriumtest wordt gedaan, zijn te verdelen in vier categorieën: Terecht Positief (TP), Fout Positief (FP), Fout Negatief (FN) en Terecht Negatief (TN).

In hoofdstuk 4 is aangegeven dat mel behulp van sensitiviteit, specificiteit en a priori kans de kansen kunnen worden bepaald dat een persoon in een van vier onderscheiden klassen terecht komt. Verder zijn er in ieder van de vier klassen verschillende kosten (C) en verschillende opbrengster (Q) te onderscheilden. In het economische evaluatiemodel spellen in principe dus 8 variabelen een rol: vier verschillende kastenen vier verschillende opbrengstencategorieen (zie tabel 6.1)

Tabel 6.1 Kosten en opbrengsiten van een test

\begin{tabular}{|c|c|c|}
\hline 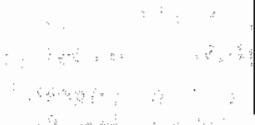 & $\begin{array}{c}0 \\
\text { wel aandoening } \\
\text { aanwlaz/g }\end{array}$ & $\begin{array}{c}\text { geen aandoening } \\
\text { aanwezig }\end{array}$ \\
\hline pasit tieve & $\mathrm{C}_{\mathrm{TP}}$ & $c_{\mathrm{PP}}$ \\
\hline testultslag T+ & $Q_{\mathrm{TP}}$ & $Q_{\mathrm{pP}}$ \\
\hline negat leve & $\mathrm{C}_{\mathrm{FN}}$ & $c_{\mathrm{TN}}$ \\
\hline testuits lag T- & $Q_{\mathrm{FN}}$ & $\mathrm{o}_{\mathrm{TN}}$ \\
\hline
\end{tabular}

$C_{T P}=$ kosten gevolgen behorende bij terecht positief

$a_{T P}=$ opbrengsten gevolgen behorende bij terecht positfef

etc.

Voor iedere specifieke testsituatie dient bepaald te worden of er sprake is van positieve of negatieve kosten en opbrengsten. Voor wat betreft het onderscheid tussen diagnostische tests en monitoring tests zijn hierover algemene uitspraken te doen.

Hieronder zal een nadere uitwerking worden gegeven van het economisch evaluatiemodel voor wat betreft de diagnostische situatie (par. 6.2).

In paragraaf 6.3 zal kort ingegaan worden op de belangrijkste verschillen in dit opzicht tussen diagnostische tests en monitoring tests.

Na de beschrijving van de componenten van het economisch model zal in paragraaf 6.4 opnieuw ingegaan worden op de bepaling van het optimale afkappunt van een continue test, maar nu zal bij de optimalisering rekening gehouden worden met kosten en

opbrengsten. Afhankelijk van de mate waarin met alle kosten- en opbrengstencategorieen rekening wordt gehouden, zijn er een zestal modelspecificaties geformuleerd. 
In paragraaf 6.5 wordt aan de hand van een rekenvoorbeeld de werking van de diverse modelspecificaties toegelicht.

\subsection{EVALUATIE MODEL DIAGNOSTISCHE TEST}

\subsubsection{Kosten}

De onderscheiden categorieën testuitslagen gaan gepaard met verschillende kosten. De kosten kunnen worden onderverdeeld in 3 componenten: de productiekosten van de test $\left(C_{2}\right)$, de kosten van vervolgdiagnostiek $\left(C_{d}\right)$ en de kosten van behandeling $\left(C_{b}\right)$.

Het is overigens niet eenvoudig de werkelijke kosten van tests en/of behandelingen te achterhalen, aangezien vaak op basis van tarieven wordt gedeclareerd. (Voor de kostenverbijzonderingsproblematiek zie o.a. Broughton \& Hogan, 1981; Leyten e.a., 1984; Stillwell, 1981; Conn e.a., 1985; Frowein e.a., 1985; Conn e.a., 1985; Frowein e.a., 1985.) Hieronder zal ingegaan worden op de wijze waarop deze kostencomponenten in het evaluatiemodel een rol spelen.

Voor iedere specifieke testsituatie zal moeten worden nagegaan; wat de kosten in de respectievelijke categorieën TP, FP, FN en TN zijn.

Blijft de testsituatie beperkt tot een enkele test, waarna de $(T+)$ een behandeling ondergaan en de (T-) niet, dan wordt voor jedere persoon testkosten gemaakt en voor TP en FP de kosten van behandeling.

De incrementele kosten $\left(\mathrm{IC}_{\text {teat }}\right)$ van de strategie "testen" ten opzichte van "iniet testen en niet behandelen " bedragen dan:

$$
\mathrm{IC}_{\text {lost }}=\mathrm{C}_{\mathrm{i}}+[\mathrm{Se} \cdot \mathrm{p}+(1-\mathrm{Sp})(1-\mathrm{p})] \mathrm{C}_{\mathrm{b}}
$$

Wordt ervan uitgegaan dat de test gevolgd wordt door een vervolgtest die bij de testpositieven foutloos onderscheid maakt tussen zieken en niet-zieken dan is het kostenplaatje als volgt samen te vatten. Voor iedere geteste persoon gelden de testkosten, voor de test-positieven gelden de kosten van vervolgtests en voor de terecht positieven gelden alleen de behandelingskosten.

Vergelijken we dit met de situatie dat er niet getest zou worden (en dus niet behandeld) dan zijn er vanzelfsprekend geen kosten voor de test noch voor de vervolgtest.

De incrementele kosten $\left(\mathrm{IC}_{\text {iest }}\right)$ van de strategie "testen" ten opzichte van "niet testen en niet behandelen" worden weergegeven door de volgende formulle:

$$
I C_{\text {teat }}=C_{t}+[S e \cdot p+(1-S p)(1-p)] C_{d}+S e \cdot p \cdot C_{b}
$$

Uit bovenstaande formule blijkt dat in deze benadering niet expliciet rekening is gehouden met de (eventuele) extra kosten die zouden kunnen ontstaan, doordat een ziek persoon ten onrechte niet ontdekt wordt en in de toekomst wellicht een duurdere 
behandeling dient te ondergaan. Indien men de strategieën "testen" vergelijkt met "niet testen", is er geen sprake van incrementele kosten (noch van incrementele opbrengsten) voor wat betreft fout-negatieve personen. $\mathrm{Er}$ is alleen sprake van incrementele kosten indien er door witvoering van de test een extra delay optreedt ten opzichte van het moment dat de ziekte in geval van "niet testen" opgespoord wordt.

\subsubsection{Opbrengsten}

Ook de effeeten op de gezondheidssituatie zullen woor de vier categorieën testuitslagen verschillen. De terecht positiewen gaan er vanwege de mogelijkheid van vroegtijdige behandeling op wooruit in gezondheid ten opzichte van de situatie waarin niet wordt getest $\left(Q_{b}\right)$, afhankelijk van de mate van effectiviteit van de therapie. $Q_{b}$ is de gemiddelde netto gezondheidswinst die te behalen is met de behandeling. Verder zijn er de (negatieve) gezondheidseffecten ten gevolge van de uitvoering van de test $\left(Q_{4}\right)$ evenals de (negatieve) gezondheidseffecten van eventuele vervolgdiagnostiek $\left(Q_{d}\right)$.

Fout-negatieve testuitslagen kunnen eveneens leiden tot een negatief effect op de gezondheid (in vergelijking met terecht positiewen) vanwege het feit dat therapie in een later stadium wordt ingesteld en daardoor mogelijk minder effectief is. Echter, in vergelijking met een situatie wamrin niet wordt getest, ondergaan deze opbrengsten geen verandering. Het schadelijk gezondheidseffect tengevolge van een FN-uitslag is pas relevant, indien later wordt behandeld.

De incrementelle effecten kunnen op dezelfde manier als de kosten worden weergegeven voor de vier categorieën testuitslagen.

Door de opbrengstcomponenten per testuitslag te vermenigvuldigen met de kans op de testuitslag worden de incrementele opbrengsten verkregen van de strategie "testen" ten opzichte van "niet testen en niet behandelen".

\subsection{VERGELIJKING EVALUATIE MONITORING TEST MET DIAGNOSTISCHE TEST}

Tests, die betrekking hebben op het diagnostisch proces, hebben tot doel informatie te verschaffen over het (al of niet) aanwezig zijn van ziekten. Wordt de ziekte aangetoond of aannemelijk gemaakt, dan kan de therapie in gang worden gezet en op die manier gezondheidswinst worden behaald.

Bij monitoring gaat het er om een indruk te krijgen van het verloop van de ziekte (en/of de invloed van de therapie op het ziekteproces), zodat therapeutisch ingrijpen eventueel kan worden gewijzigd.

In een economische evaluatie dienen zowel de kosten als opbrengsten bekeken te worden. De modelformulering die hier ontwikkeld wordt maakt het mogelijk een dergelijke economische evaluatie uit te voeren, zowel met betrekking tot diagnostische als monitoring tests.

Wat zijn de kenmerkende verschillen in kosten en opbrengsten tussen monitoring tests en diagnostische tests? 
Via diagnostische tests wordt beoogd gezondheidswinst te bewerkstelligen, waar tegenover dan de kosten van opsporen en behandelen staan. Vermindering van diagnostiek leidt tot minder ontdekking van zieken waardoor minder vervolgtests nodig zijn. Op korte termijn leidt dit tot geringere behandelingskosten. Op langere termijn komen de extra behandelingskosten van FN hier tegenover te staan. Beperking van diagnostische tests leidt tot de substitutie tussen preventief en curatief ingrijpen.

Monitoring tests hebben tot effect dat de behandelingsintensiteit kan worden aangepast, indien dit medisch gezien verantwoord is Daarbij moeten overigens de gezondheidseffecten niet verwaarloosd worden. Besparen op monitoring tests kan leiden tot een situatie waarbij reeds herstelde patiënten te lang in het ziekenhuis verblijven, hetgeen tot additionele kosten leidt. Voor beperking van monitoring tests is de substitutie tussen care en cure relevant. Bij diagnostische tests gaat het primair om de te behalen gezondheidswinst, bij monitoring tests gaat het om een mogelijkheid tot kostenbesparing.

Anders geformuleerd: Monitoring tests kunnen meer gezien worden in functie van kostenbesparing, terwijl bij diagnostische tests meer nadruk ligt op de te behalen gezondheidswinst.

\subsection{OPTIMALISATIEMODELLEN}

\subsubsection{Inlelding}

In deze paragraaf wordt opnieuw ingegaan op het bepalen van het optimale afkappunt bij een continue test. In hoofdstuk 4 is dit probleem reeds behandeld, waarbij is afgezien van de mogelijke kosten en opbrengsten.

In de literatuur worden verschillende modelspecificaties aangetroffen. Hieronder zullen de diverse mogelijke modellen worden besproken en met elkaar vergeleken.

- In de eerste plaats wordt een model gehanteerd dat de minimalisering van het aantal foutmeldingen representeert (model 1). Deze modelspecificatie is reeds in hoofdstuk 4 ter sprake gekomen.

Op de tweede plaats zullen enkele modellen worden besproken, die tot doel hebben de kosten te minimaliseren. Daarbinnen kunnen twee modellen worden geformuleerd:

- Het minimaliseren van de kostenconsequenties van foutmeldingen (model 2). Een dergelijke modelspecificatie wordt veelvuldig in de literatuur aangetroffen (Finkelstein \& Kristein, 1982; Applegate, 1981; Barr, 1981; McNeil e.a., 1975). Het minimaliseren van de totale kostenconsequenties (model 3). Ook hiervan zijn vele voorbeelden aan te halen (Metz, 1978; Sondik, 1982; Eeckhoudt, 1984). Er kan echter ook gekozen worden voor een maximalisering van de opbrengsten. In principe kan ook in dat geval gekozen worden voor verschillende modelspecificaties, maar het meest voor de hand ligt om de totale opbrengsten te maximaliseren (model 4) (Pauker \& Kassirer, 1980).

Bij een complete economische evaluatie van het optimale afkappunt zullen echter de kosten- en opbrengstenfaetoren in de beschouwing betrokken dienen te worden. 
In eerste instantie wordt ervan uitgegaan dat de opbrengsten in een andere eenheid zijn uitgedrukt dan de kosten, zodat alleen de verhouding tussen opbrengsten en kosten kan worden geoptimaliseerd door verschuiving van de drempelwaarde van de test (model 5). Soms wordt ervan uitgegaan dat terechte uitslagen leiden tot opbrengst, terwijl onjuiste uitslagen gepaard gaan met kosten (Lusted, 1972). Dit model kan op eenvoudige wijze aan model 5 worden gerelateerd en zal derhalve niet apart worden vermeld.

Optimalisering kan echter ook plaatsvinden door maximalisering van het verschil tussen opbrengsten en kosten, maar dan moeten de opbrengsten uitgedrukt worden in dezelfde eenheid als de kosten. In model 6 wordt ervan uitgegaan dat de opbrengsten in geld kunnen worden gewaardeerd, door de opbrengsten uitgedrukt in QALY's te vermenigvuldigen met de in geld uitgedrukte waarde van een QALY.

\subsubsection{Het model}

Voor het bepalen van het optimale afkappunt $(x)$ van een test met een continu waardenbereik, wordt uitgegaan van twee verdelingen van zieken $f_{1}(t)$ en niet-zieken $\mathrm{f}_{2}(\mathrm{t})$.

Figuur 6.1. Verdeling zieken en niet-zieken

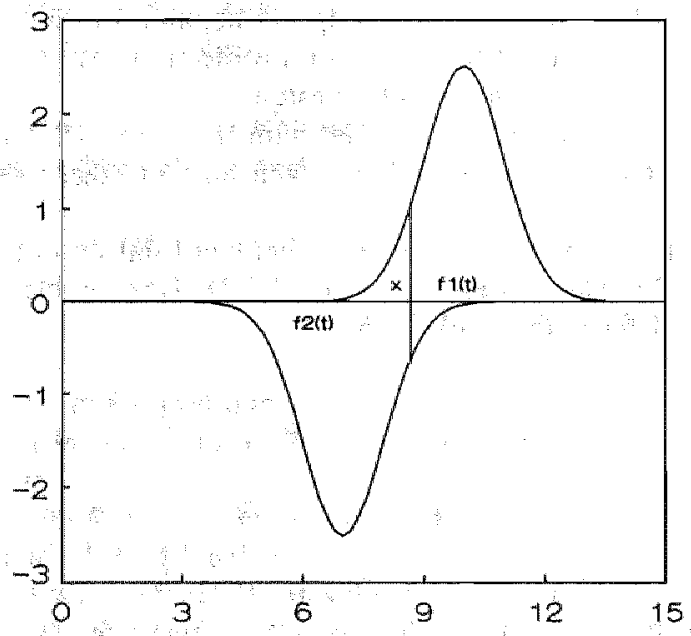

De totale kosten $K(t)$ kunnen nu met behulp van onderstaande formule als volgt worden bepaald. Op ieder willekeurig punt van het waardenbereik van de test geldt: 


$$
\begin{aligned}
& K(t)=p C_{T P} \int_{x}^{\infty} f_{1}(t) d t+p C_{\mathrm{RN}} \int_{-\infty}^{x} f_{1}(t) d t+ \\
& +(1-p) C_{\mathrm{RP}} \int_{x}^{\infty} f_{2}(t) d t+(1-p) C_{\mathrm{TN}} \int_{-\infty}^{x} f_{2}(t) d t
\end{aligned}
$$

Voor een waarde $t=x$, waarop de kosten minimaal zijn, geld dat de eerste afgeleide van de kostenfunctie $K(t)$ gelijk dient te zijn aan nul. Dus in het punt $t=x$ geldt:

$$
\frac{d K(t)}{d t}=0
$$

Uit (1) en (2) vollgt dat in punt $t=x$ geldt:

$$
\frac{p\left(C_{T P}-C_{F N}\right) d \int_{-\infty}^{x} f_{1}(t) d t+(1-P)\left(C_{T P}-C_{T N}\right) d \int_{-\infty}^{x} f_{2}(t) d t=0}{d t} \frac{\int_{-\infty}^{x}}{d t}
$$

In punt $\mathrm{t}=\mathrm{x}$ geldt tevens dat:

$$
\frac{\int_{-\infty}^{\int_{1}} f_{1}(t) d t=f_{1}(x)}{d t} \text { en } \frac{\int_{-\infty}^{x} f_{2}(t) d t}{d t}=f_{2}(x)
$$


zodat

$$
\mathrm{p}\left(\mathrm{C}_{\mathrm{TP}}-\mathrm{C}_{\mathrm{PN}}\right) \mathrm{f}_{1}(\mathrm{x})+(1-\mathrm{p})\left(\mathrm{C}_{\mathrm{FP}}-\mathrm{C}_{\mathrm{TN}}\right) \mathrm{f}_{2}(\mathrm{x})=0
$$

Hieruit wolgt dat:

$$
\frac{f_{1}(x)}{f_{2}(x)}=-\frac{(1-p)}{p} \frac{\left(C_{\mathrm{PP}}-C_{T N}\right)}{\left(C_{T P}-C_{P N}\right)}
$$

M.a.w.: Het optimale afkappunt wordt gevonden voor die waarde van $\mathrm{x}$ waarvoor de verhouding van de functiewaarden van de respectievelijke functies $f_{1}(x)$ en $f_{2}(x)$ gelijk is aan de factor:

$$
-\frac{(1-\mathrm{p})}{\mathrm{p}} \frac{\left(\mathrm{C}_{\mathrm{Pp}}-\mathrm{C}_{\mathrm{TN}}\right)}{\left(\mathrm{C}_{\mathrm{TP}}-\mathrm{C}_{\mathrm{FN}}\right)}
$$

Bovenstaande formule is bruikbaar indien men beschikt over de onderliggende verdeling van "zieken" en "niet-zieken". In de praktijk zal men echter vaker de beschikking hebben over de karakteristieken van de test in de vorm van een ROC-curve en is het aantrekkelijk om de kostenfunctie weer te geven in termen van sensitiviteit en specificiteil.

In de formules kunnen daartoe de integralen vervangen worden door de begrippen sensitiviteit en specificiteit, waarbij geldt dat:

$$
S e=\int_{x}^{\infty} f_{1}(t) d t
$$

en voor $t=x$ geldt dat:

$$
\frac{d S e}{d t}=-f_{1}(x)
$$


Op dezelfde wijze geldt:

$$
S p=\int_{-\infty}^{x} f_{2}(t) d t
$$

en voor $t=x$ geldt:

$$
\frac{d S p}{d t}=f_{2}(x)
$$

Het optimalle afkappunt kan dan worden bepaald uit de volgende vergelijking:

$$
\frac{d S e}{d S p}=\frac{(1-p)}{p} \frac{\left(C_{\mathrm{FP}}-C_{\mathrm{TN}}\right)}{\left(\mathrm{C}_{\mathrm{TP}}-\mathrm{C}_{\mathrm{FN}}\right)}
$$

Het optimale afkappunt wordt gevonden daar waar de richtingscoeffficiënt van de raaklijn aan de ROC-curve de waarde aanneemt weergegeven door de rechter term van de vergelijking.

In principe moet nog bewezen worden dat in het betreffende punt de kostenfunctie een minimum aanneemt en geen maximum. Wiskundig zou dit aangetoond kunnen worden via het bepalen van de tweede afgeleide. Eenvoudiger is het om van een bepaald punt, bijvoorbeeld het punt waar de sensitiviteit en de specificiteit gelijk zijn aan respectievelijk éen en nul, aan te tonen dat de kosten hoger zijn dan in het betreffende punt.

In het punt ( $\mathrm{Se}=1, \mathrm{Sp}=0$ ) is de eerste afgeleide van de kostenfunctie gelijk aan $\mathrm{p}\left(\mathrm{C}_{\mathrm{TP}}-\mathrm{C}_{\mathrm{FN}}\right)$.

In het punt ( $\mathrm{Se}=0, \mathrm{Sp}=1$ ) is de eerste afgeleide van de kostenfunctie (1-p) $\left(\mathrm{C}_{\mathbb{D N}}\right.$ $\mathrm{C}_{\mathrm{PP}}$ ).

Indien $\mathrm{C}_{\mathrm{TP}}-\mathrm{C}_{\mathrm{PN}}<0$ en $\mathrm{C}_{\mathrm{FP}}-\mathrm{C}_{\mathrm{TN}}>0$ is in het betreffende punt sprake van een minimum. Ook uit formule (6.3) blijkt overigens dat de factoren $\left(\mathrm{C}_{\mathrm{FP}}-\mathrm{C}_{\mathrm{TN}}\right)$ en $\left(\mathrm{C}_{\mathrm{TP}} \mathrm{P}^{-}\right.$ $\mathrm{C}_{\mathrm{PN}}$ ) tegengesteld aan elkaar moeten zijn. Is aan deze voorwaarde niet voldaan, dan bevindt het minimum van de kostenfunctie zich in een van de twee uitersten van de ROC-curve.

Het bepalen van het optimale punt op de ROC-curve volgens bovenstaande formule betekent dat met alle kostenconsequenties rekening wordt gehouden. Hiervóor is dit aangeduid als model 3. In de literatuur treft men situaties aan waarbij de consequenties van foutmeldingen worden geminimaliseerd. Het afkappunt van de test, waarbij sprake is van minimale kosten van foute vitslagen, kan gevonden worden door in formule 6.4 de betreffende kosten behorende bij terechte witslagen op nul te stellen 
(model 2). Indien men daarentegen alleen geinteresteerd is in het total aantal goede

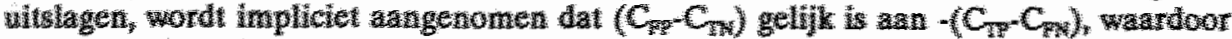
de rechter term uit formule 6.4 wordi gereduceerd tot $-(1-p) / p$ (model 1$)$.

De optimalisering wan de opbrengsten kan op identieke wijze worden verkregen. In plats yan de Lastentcomponenten worden no de opbrengstencomponenten in de formule gebruikt (nodel 4).

$$
\frac{d S e}{d S p}=\frac{(1-p)}{p} \frac{\left(Q_{F}-Q_{n w}\right)}{\left(Q_{w}-Q_{n N}\right)}
$$

Evenals het geval was bij de kosten moet nog bewezen worden dat nu hel betreffende pust en maximum in de opbrengsten impliceert. Indien $\left(Q_{p p}-Q_{N N}\right)<0$ en $\left(Q_{T P}-Q_{p N}\right)>0$ is hieraan woldaan.

Indien kosten en opbrengsten afzonderlijk geoptimaliseerd worden dan is het onwaarschijnlijk dat deze optima in hetzelfde afkappunt plaatsvinden.

Indien kosten en opbrengsten in eenzelfde eenheid zijn uitgedrukt, bijwoorbeeld geld, dan Lunnen per categorie (TP, FP, FN en TN) de netto-opbrengsten (O-K) worden bepald (model 6). In dat geval word het optimum gevonden in het punt op de ROCcurve, warvoor geldt:

$$
\frac{d S e}{d S p}=\frac{(1-p)}{p} \frac{\left(U_{p p}-U_{m N}\right)}{\left(U_{m p}-U_{F M}\right)}
$$

$U_{\mathrm{pg}}$ is het "nut" behorende bij een fout-positieve testuitsigg en zal derhalve valk een negatieve waarde hebben. Dit nut word werkregen door het antal $\mathrm{QALY}$ 's $\left(\mathrm{Q}_{\mathrm{PP}}\right)$, te vermenigvaldigen met de waarde van een $Q A L Y(M)$ en er vervolgens de kostea ( $\left.C_{\mathrm{F}}\right)$ vanaf te trekken. Op overeenkomstige wijze kusnen $U_{\mathrm{T}}, U_{\mathrm{T}}$ en $U_{\mathrm{F}}$ gedefinieerd worden.

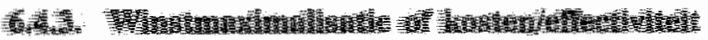

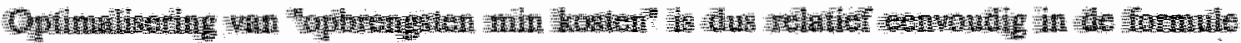

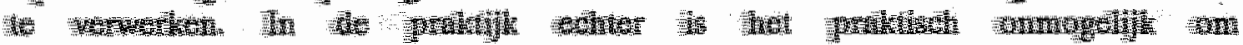

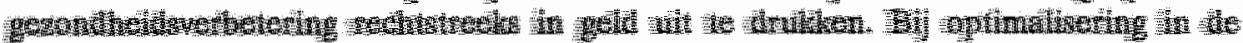
958

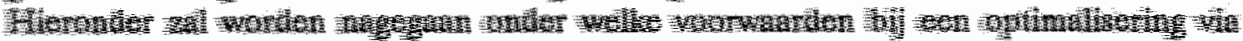

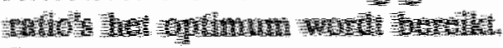

Bera

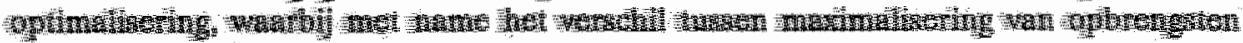

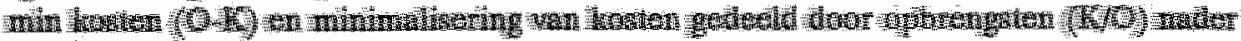

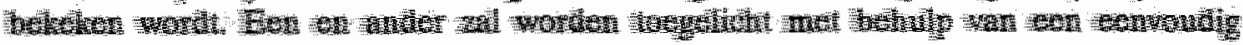

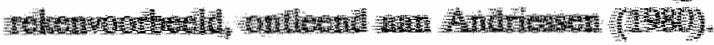


Indien de kosten- en opbrengstenfuncties bekend zijn is het op een tweetal manieren mogelijk om de productie-omvang te bepalen, waarbij de totale winst gemaximaliseerd wordt (Andriessen, 1980).

In de eerste plaats kan de winstfunctie worden bepaald uit de opbrengst- en kostenfuncties. Daar waar de eerste afgeleide van de winstfunctie gelijk is aan nul, is de winst maximaal (indien de tweede afgeleide groter is dan nul).

In de tweede plaats kan het optimum gevonden worden door uit te gaan van de marginale benadering. De productie moet uitgebreid worden zolang de productie van een extra eenheid gepaard gaat met meer opbrengsten dan kosten. Daar waar de marginale opbrengsten gelijk zijn aan de marginale kosten is de winst maximaal. Beide methoden leveren hetzelfde productieniveau op als eindresultaat.

De tweede methode heeft het praktische voordeel, dat de totale kosten- en opbrengstenfuncties (TK en TO) niet volledig bekend hoeven te zijn voor alle productieniveau's om de optimale productie-omvang te kunnen vaststellen. Varend op het kompas van de marginale benadering, kan deze optimale productie-omvang toch worden bepaald.

Een voorbeeld:

$$
\begin{aligned}
& \text { TK }=100 x+300 \quad \text { voor } 0<x \leq 4 \\
& \text { TK }=25 x^{2}-100 x+700 \text { voor } 4<x<7 \\
& \text { TO }=200 x
\end{aligned}
$$

waarbij $\mathrm{x} \quad=$ productie-omvang

$\mathrm{TK}=$ totale kosten

TO $=$ totale opbrengsten

Aan de hand van onderstaande figuur kan de werking van beide methodes geillustreerd worden. In de eerste plaats kan de totale winstfunctie worden bepaald en vervolgens het maximum hiervan. In de marginale benadering wordt aan de TK-functie een raaklijn getrokken (MK), evenwijdig aan de TO-functie. 
Figuur 6.2. Kosten (TK) en Opbrengsten (TO) en Winst (TW)

(Bron: Andriessen, 1980)

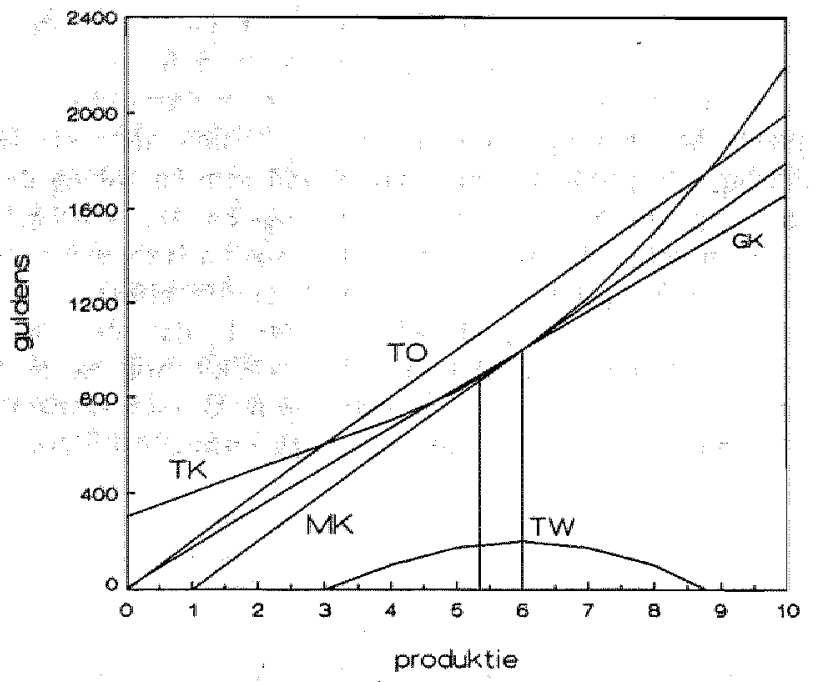

Uit de figuur blijkt dat de winst maximaal is bij een productieniveau van 6 eenheden. Deze methode om het maximum te bepalen via het criterium O-K kan hier worden toegepast omdat kosten en opbrengsten beiden in geld zijn uitgedrukt.

Wanneer dit niet het geval is, zoals in de gezondheidszorg waar opbrengsten in QALY's zijn uitgedrukt; kan wel de verhouding tussen kosten en opbrengsten worden geoptimaliseerd. In feite kunnen nu ook weer twee manieren worden gebruikt om het optimum te bepalen. In de eerste plaats kan uit de opbrengsten- (GO) en kostenfunctie (GK) de K/O-functie worden samengesteld. Door differentiëring kan het minimum van de functie worden bepaald. Het blijkt dat; in het voorbeeld ontleend aan Andriessen, dit optimum plaatsvindt bij een productieniveau van 5,29 eenheden.

De tweede manier maakt gebruik van de gemiddelde opbrengsten- en kostenfuncties afzonderlijk. De optimale $\mathrm{K} / \mathrm{O}$-verhouding wordt bereikt daar waar de afstand tussen de gemiddelde opbrengsten- en de gemiddelde kostenfunctie het grootst is. Aangezien de gemiddelde opbrengstenfunctie constant is (in dit voorbeeld) wordt dit punt bereikt in het minimum van de gemiddelde kostenfunctie. In grafiek 6.2 kan dit punt gevonden worden door wit de oorsprong de raaklijn aan de kostencurve te trekken. Het optimum volgens het criterium O-K wordt bereikt daar waar de raaklijn aan de TK-curve evenwijdig loopt aan de TO-curve.

Uit het bovenstaande betoog kunnen enkele conclusies getrokken worden, die verband houden met optimalisering in de gezondheidszorg volgens het $\mathrm{O}-\mathrm{K}$ criterium dan wel het K/O criterium.

De optimale productie-omvang waarbij het criterium O-K geldt, wordt gevonden daar waar TK'(x) gelijk is aan TO'(x). Het punt wordt bereikt in de grafiek waar de richtingscoëfficiënt van de raaklijnen aan de curven $T K(x)$ en $T O(x)$ evenwijdig lopen. Er kan echter ook geoptimaliseerd worden volgens het K/O criterium. Het grootste verschil tussen gemiddelde kosten en gemiddelde opbrengsten wordt verkregen bij die 
x, waar de richtingscoëfficiènt van de raaklijn aan de TK-curve zo klein mogelijk is (omdat in dit geval de gemiddelde opbrengst constant is).

In het betreffende cijfervoorbeeld is het zo dat de optimale productie-omvang, bepaald via het $\mathrm{K} / \mathrm{O}$ criterium geringer is dan het productieniveau waarbij de totale winst wordt gemaximaliseerd. Een belangrijke vraag is of dit een algemeen versehijnsel is en derhalve ook binnen de gezondheidszorgsector het geval is. In het algemeen zal dit inderdaad het geval zijn bij kostenfuncties met een exponentieel verloop.

Ook binnen de gezondheidszorgsector zal het zo zijn dat het produceren van QALY's gepaard gaat met toenemende kosten. De productie-omvang vastgesteld via het criterium $\mathrm{K} / \mathrm{O}$ zal dus kleiner zijn dan indien bepaald via het criterium $\mathrm{O}-\mathrm{K}$.

Kan hieruit de conclusie getrokken worden dat optimalisering via $\mathrm{K} / \mathrm{O}$ leidt tot een situatie waarin niet de totale winst wordt gemaximaliseerd?

De totale winst is bij een productieniveau bepaald via het $\mathrm{K} / \mathrm{O}$-criterium kleiner dan bij een productieniveau bepaald door het criterium $\mathrm{O}-\mathrm{K}$, maar er worden ook minder middelen vastgelegd in totaal. Indien deze middelen worden aangewend in alternatieve richtingen, waar de gemiddelde opbrengst gelijk is aan de gemiddelde opbrengst bij $K / O$, dan is in totaal de wimst groter. De benadering via de $\mathrm{K} / \mathrm{O}$ verhouding houdt dus een extra veiligheid in om in totaal een zo hoog mogelijke winst te bereiken, al is deze winst afhankelijk van de winstkwaliteit van de alternatieve bestedingen.

In het bovengenoemde voorbeeld, is de winst bij de optimalisering volgens beide criteria in onderstaande tabel weergegeven.

Tabel 6.2. Optimalisering volgens criteria $\mathrm{O}-\mathrm{K}$ en $\mathrm{K} / \mathrm{O}$

$\begin{array}{ccccccc}\text { Criteria } & \text { Productie-omvang } & \text { TK } & \text { To } & \text { TW } & \mathbb{K} / 0 & (0 / \mathrm{K}) \\ 0-\mathrm{K} & 6 & 1000 & 1200 & 200 & .833 & (1,2) \\ \mathrm{K} / 0 & 5,29 & 870,6 & 1058 & 187,4 & .823 & (1,2153)\end{array}$

Incremen-

teel $\quad 129,4 \quad 142 \quad .94 \quad(1,0974)$

De totale winst bij het criterium $\mathrm{O}-\mathrm{K}$ is groter dan bij het criterium $\mathrm{K} / \mathrm{O}$. Indien men voor de keuze staat voor een productie-omvang van 6 eenheden dan wel 5,29 kan de volgende redenering gevolgd worden. $\mathrm{Bij}$ een omvang wan 5,29 eenheden is het gemid. delde rendement wan iedere geinvesteerde gulden 1,2153 en dit loopt terug tot 1,2 bij een omvang van 6 eenheden. Dit wordt veroorzaakt doordat het rendement van de productie-uitbreiding van 5,29 naar 6 eenheden, een lager rendement heeft (iedere extra geinvesteerde gulden levert 1,0974 gulden op. Zolang er geen alternatieve besteding mogelijk is met een hoger rendement dan het berekende rendement zal uitbreiding van de productie-omvang tot 6 cenheden wenselijk zijn. 
Indien kosten en opbrengsten niet in dezelfde eenheid zijn uitgedrukt, kan eenzelfde redenering worden gehanteerd.

Stel dat de opbrengsten in QALY $\left(\mathrm{O}_{1}\right.$ en $\left.\mathrm{O}_{2}\right)$ en kosten $\left(\mathrm{K}_{1}\right.$ en $\left.\mathrm{K}_{2}\right)$ van twee programma's bekend zijn.

De vraag is wanneer hantering van verschillende criteria kan leiden tot verschillende oplossingen en wanneer beide criteria tot eenzelfde resultaat leiden.

Het zal duidelijk zijn dat de maximale waarde van een QALY (M) hierbij een belangrijke rol vervult.

De betreffende KE-ratio's van de programma's zijn:

Programma 1. $\mathrm{K}_{2} / \mathrm{O}_{1}$

Programma 2. $\mathrm{K}_{2} / \mathrm{O}_{2}$

Stel verder dat $\mathrm{K}_{1} / \mathrm{O}_{1}>\mathrm{K}_{2} / \mathrm{O}_{2}$ hetgeen impliceert dat programma 2 onder criterium $\mathrm{K} / \mathrm{O}$ de beste strategie is.

Onder welke voorwaarde is dit ook het geval bij hantering van het criterium O-K? In dat geval moet gelden:

$$
\mathrm{O}_{2} * \mathrm{M}-\mathrm{K}_{2}>\mathrm{O}_{1} * \mathrm{M}-\mathrm{K}_{1}
$$

ofwel

$$
\begin{array}{lll}
M>\left(\mathrm{K}_{2}-\mathrm{K}_{1}\right) /\left(\mathrm{O}_{2}-\mathrm{O}_{1}\right) & \text { indien } & \mathrm{O}_{2}>\mathrm{O}_{1} \\
\mathrm{M}<\left(\mathrm{K}_{2}-\mathrm{K}_{1}\right) /\left(\mathrm{O}_{2}-\mathrm{O}_{1}\right) & \text { indien } & \mathrm{O}_{2}<\mathrm{O}_{1}
\end{array}
$$

Hierdoor wordt in feite een relatie gelegd tussen $M$ en de incrementele kosten en opbrengsten van de programma's.

Voorbeeld

O $\quad \mathrm{K} \quad \mathrm{K} / \mathrm{O}$

Programma in QALY in guldens in guldens per QALY

$\begin{array}{llll}1 & 2 & 3.000 & 1.500 \\ 2 & 1 & 1.000 & 1.000\end{array}$

Programma 2 is het meest wenselijk gezien de $\mathrm{K} / \mathrm{O}$ verhouding.

$\mathrm{O}_{2}$ is kleiner dan $\mathrm{O}_{1}$, dus moet $M$ kleiner zijn dan $f 2.000$,- om programma 2 ook onder het criterium O-K het meest wenselijk te doen zijn. Indien $M>f 2,000$ is programma 1 te verkiezen op grond van het criterium $\mathrm{O}-\mathrm{K}$.

\subsubsection{Optimaal afkappunt}

Voor de bepaling van het optimale afkappunt van een test kunnen de respectievelijke kosten- en opbrengstenfuncties als volgt worden gespecificeerd: 
$\mathrm{K}(\mathrm{x})=\mathrm{p} \mathrm{C}_{\mathrm{TP}} \mathrm{Se}+\mathrm{p} \mathrm{C}_{\mathrm{FN}}(1-\mathrm{Se})+(1-\mathrm{p}) \mathrm{C}_{\mathrm{FP}}(1-\mathrm{Sp})+(1-\mathrm{p}) \mathrm{C}_{\mathrm{IN}} \mathrm{Sp}$

$O(x)=p Q_{T p} S e+p Q_{p N}(1-S e)+(1-p) Q_{\mathrm{FP}}(1-S p)+(1-p) Q_{T N} S p$

Sensitiviteit en specificiteit zijn te beschouwen als functies van $\mathrm{x}$, het afkappunt. Uit bovenstaande formules kunnen de afgeleiden van de functies worden bepaald.

$$
\begin{aligned}
& K^{\prime}(x)=\frac{d S e}{d x} p\left(C_{T P}-C_{\mathrm{FN}}\right)-\frac{d S p}{d x}(1-p)\left(C_{\mathrm{FP}}-C_{T N}\right) \\
& O^{\prime}(x)=\frac{d S e}{d x} p\left(Q_{T P}-Q_{\mathrm{FN}}\right)-\frac{d S p}{d x}(1-p)\left(Q_{\mathrm{FP}}-Q_{\mathrm{TN}}\right)
\end{aligned}
$$

Wij zijn nu geïnteresseerd in de functie $\mathrm{K}(\mathrm{x}) / \mathrm{O}(\mathrm{x})$ en zoeken naar een punt waar deze verhouding zo gunstig mogelijk is, dat wil zeggen het minimum bereikt. Dit minimum wordt bereikt in het punt waar geldt:

$$
\frac{d(K(x) / O(x))}{d x}=\frac{K^{\prime}(x) O(x)-K(x) O^{\prime}(x)}{(O(x))^{2}}
$$

Worden bovenstaande formules van de afgeleiden in de formule (6.11) gesubstitueerd en wordt de teller gelijk aan nul gesteld dan volgt formule (6.12):

$$
\begin{aligned}
& \frac{d S e}{d x} p\left\{\left(Q_{T P}-Q_{\mathrm{PN}}\right) K(x)-\left(C_{\mathrm{TP}}-C_{\mathrm{FN}}\right) \mathrm{O}(\mathrm{x})\right\}= \\
& =\frac{\mathrm{dSp}}{d x}(1-\mathrm{p})\left\{\left(\mathrm{Q}_{\mathrm{PP}}-\mathrm{Q}_{\mathrm{TN}}\right) \mathrm{K}(\mathrm{x})-\left(\mathrm{C}_{\mathrm{PN}}-\mathrm{C}_{\mathrm{TN}}\right) \mathrm{O}(\mathrm{x})\right\}
\end{aligned}
$$

zodat het optimum wordt bereikt indien formule (6.13) geldt.

$$
\frac{d S e}{d S p}=\frac{(1-p)}{p} \frac{\left\{\left(Q_{\mathrm{Pp}}-Q_{\mathrm{TN}}\right) K(x)-\left(C_{\mathrm{FP}}-\mathrm{C}_{\mathrm{TN}}\right) \mathrm{O}(\mathrm{x})\right\}}{\left\{\left(\mathrm{Q}_{\mathrm{TP}}-\mathrm{Q}_{\mathrm{PN}}\right) \mathrm{K}(\mathrm{x})-\left(\mathrm{C}_{\mathrm{TP}}-\mathrm{C}_{\mathrm{PN}}\right) \mathrm{O}(\mathrm{x})\right\}}
$$


Deze formule heeft dezelfde structuur als de formules (6.4), (6.5) en (6.6). Hei verlies ten gevolge van het ten onrechte behandelen van een gezond persoon, moet vermenigvuldigd worden met de totale kosten, behorende bij het optimale afkappunt. Hier worden de kosten van het ten onrechte behandelen van een gezond persoon, vermenigvuldigd met de totalle opbrengst, vanaf getrokken. Op dezelfde wijze wordt de noemer bepaald, waarbij dan, zoals in voorgaande formules, de verschillen in kosten en opbrengsten van TP versus FN een rol spelen. Dat hier twee werschillende dimensies, kosten en gezondheidswinst met elkaar vermenigvaldigd worden, is geen probleem omdat in teller en noemer dezelfde dimensies staan, zodat uiteindelijk alleen de verhouding meetelt.

Worden opbrengsten en kosten in dezelfde eenheid uitgedrukt dan is duidelijk dat formule (6.13) gelijk is aan formule (6.6). Indien de kosten worden geminimaliseerd wordt formulle (6.4) verkregen door de opbrengsten gelijk aan nul te stellen en formule (6.5) kan worden verkregen door de kosten gelijk aan nul te stellen.

Een groter probleem vormt het feit dat de kosten- en opbrengstenfuncties afhankelijk zijn van het afkappunt en dus van de sensitiviteit en specificiteit. Het optimaal afkappunt kan dus niet rechtstreeks bepaald worden uit formule (6.13). Wel kan het gevonden worden door een iteratieve rekenprocedure.

$\mathrm{Er}$ is echter een andere mogelijkheid om inzichtelijk te maken hoe de bepaling van het optimale afkappunt via het $\mathrm{K} / \mathrm{O}$ criterium zich voltrekt en hoe dit zich verhoudt tot de bepaling van het optimale afkappunt via het criterium $\mathrm{O}-\mathrm{K}$.

Uitgaande van de kosten- en opbrengstenfuncties (7) en (8) kan het punt bepaald worden waar geldt, dat zowel de opbrengsten als de kosten gelijk zijn aan nul.

De twee formules, waarmee het betreffende nul-punt kan worden gevonden, zijn:

Kostenlijn:

$$
\mathrm{Se}=\frac{(1-\mathrm{p})}{\mathrm{p}} \frac{\left(\mathrm{C}_{\mathrm{TP}}-\mathrm{C}_{\mathrm{TN}}\right)}{\left(\mathrm{C}_{\mathrm{TP}}-\mathrm{C}_{\mathrm{FN}}\right)} \mathrm{Sp} \cdot \frac{\mathrm{pC}_{\mathrm{FN}}+(1-\mathrm{p}) \mathrm{C}_{\mathrm{FP}}}{\mathrm{p}\left(\mathrm{C}_{\mathrm{TP}}-\mathrm{C}_{\mathrm{PN}}\right)}
$$

Opbrengstenlijn:

$$
\mathrm{Se}=\frac{(1-\mathrm{p})}{\mathrm{p}} \frac{\left(\mathrm{Q}_{\mathrm{FP}}-\mathrm{Q}_{\mathrm{TN}}\right)}{\left(\mathrm{Q}_{\mathrm{TP}}-\mathrm{Q}_{\mathrm{pN}}\right)} \mathrm{Sp}-\frac{p \mathrm{Q}_{\mathrm{FN}}+(1-\mathrm{p}) \mathrm{Q}_{\mathrm{PP}}}{\mathrm{p}\left(\mathrm{Q}_{\mathrm{TP}}-\mathrm{Q}_{\mathrm{PN}}\right)}
$$

Dit punt heeft een bijzondere betekenis voor het bepalen van het optimale afkappunt volgens K/O. Er kan namelijk bewezen worden dat alle punten op een rechte lijn, die door het betreffende nul-punt gaat, gekenmerkt worden door eenzelfde $\mathrm{K} / \mathrm{O}$ verhouding. 
De formules (6.7) en (6.8) bevatten de specificaties van de kosten- en opbrengstenfuncties. Deze formules kunnen vereenvoudigd worden tot

$$
\begin{aligned}
& \mathrm{K}(\mathrm{Sp}, \mathrm{Se})=\mathrm{C}_{1} \mathrm{Se}+\mathrm{C}_{2} \mathrm{Sp}+\mathrm{p} \mathrm{C}_{\mathrm{pN}}+(1-\mathrm{p}) \mathrm{C}_{\mathrm{PP}} \\
& \mathrm{Q}(\mathrm{Sp}, \mathrm{Se})=\mathrm{Q}_{1} \mathrm{Se}+\mathrm{Q}_{2} \mathrm{Sp}+\mathrm{p} \mathrm{Q}_{\mathrm{FN}}+(1-\mathrm{p}) \mathrm{Q}_{\mathrm{FP}}
\end{aligned}
$$

waarbij geldt:

$$
\begin{aligned}
& \mathrm{C}_{1}=\mathrm{p}\left(\mathrm{C}_{\mathrm{TP}}-\mathrm{C}_{\mathrm{PN}}\right) \\
& \mathrm{C}_{2}=(1-\mathrm{p})\left(\mathrm{C}_{\mathrm{TN}}-\mathrm{C}_{\mathrm{PP}}\right) \\
& \mathrm{Q}_{1}=\mathrm{p}\left(\mathrm{Q}_{\mathrm{TP}}-\mathrm{Q}_{\mathrm{PN}}\right) \\
& \mathrm{Q}_{2}=(1-\mathrm{p})\left(\mathrm{Q}_{\mathrm{TN}}-\mathrm{Q}_{\mathrm{PP}}\right)
\end{aligned}
$$

Sensitiviteit en specificiteit hebben alleen een reële betekenis in het gebied waar zowel sensitiviteit als specificiteit waarden aannemen tussen nul en één (zie ROC-curve).

We gaan nu op zoek naar het punt waar zowel de kosten als de opbrengsten gelijk zijn aan nul. Indien de betreffende lijnen (7) en (8) niet evenwijdig aan elkaar lopen, kan dit punt bepaald worden door het volgende stelsel van lineaire vergelijkingen op te lossen:

$$
\begin{aligned}
& K(x, y)=0 \\
& O(x, y)=0
\end{aligned}
$$

Het betreffende punt met de coördinaten $\mathrm{Se}^{\circ}$ en $\mathrm{Sp}^{\circ}$, dat zich eventueel buiten het ROC-gebied kan bevinden en waarvoor dan geen reele interpretatie mogelijk is, speelt toch een belangrijke rol bij de vraag hoe het optimale afkappunt op de ROC-curve, gegeven het $\mathrm{K} / \mathrm{O}$ criterium grafisch kan worden bepaald. In het betreffende punt is de $\mathrm{K} / \mathrm{O}$ werhouding onbepaald (Opbrengst is nul).

De lijn door een willekeurig punt met een bepaalde sensitiviteit en specificiteit en het betreffende nul-punt heeft een richtingscoefficient van:

$$
b=\frac{S e-S e^{\circ}}{S p-S p^{\circ}}
$$


Formules (6.16) en (6.17) kunnen worden herschreven. In het nul-punt geldt voor formule (6.16):

$$
\mathrm{K}\left(\mathrm{Sp}^{\circ}, \mathrm{Se}^{\circ}\right)=0
$$

Hieruit volgt

$$
\mathrm{C}_{1} \mathrm{Se}^{0}+\mathrm{C}_{2} \mathrm{Sp^{0 }}+\mathrm{p} \mathrm{C}_{\mathrm{PN}}+(1-\mathrm{p}) \mathrm{C}_{\mathrm{pP}}=0
$$

dus

$$
p C_{\mathrm{PN}}+(1-\mathrm{p}) \mathrm{C}_{\mathrm{PP}}=-\mathrm{C}_{1} S \mathrm{Se}^{\circ}-\mathrm{C}_{2} \mathrm{Sp}^{\circ}
$$

$\mathrm{Na}$ substitutie in (6.16) volgt:

$$
\mathrm{K}(\mathrm{Sp}, \mathrm{Se})=\mathrm{C}_{1}\left(\mathrm{Se}-\mathrm{Se}^{\circ}\right)+\mathrm{C}_{2}\left(\mathrm{Sp}-\mathrm{Sp}^{\circ}\right)
$$

Op identieke wijze kan bewezen worden

$$
\mathcal{O}(\mathrm{Sp}, \mathrm{Se})=\mathrm{Q}_{1}\left(\mathrm{Se}-\mathrm{Se}^{\circ}\right)+\mathrm{Q}_{2}\left(\mathrm{Sp}-\mathrm{Sp}^{\circ}\right)
$$

Substitueren we in deze vergelijking

$$
\mathrm{Se}-\mathrm{Se}^{\circ}=\mathrm{b}\left(\mathrm{Sp}-\mathrm{Sp}^{\circ}\right)
$$

en delen we (6.18) door (6.19) dan volgt:

$$
\frac{K(S p, S e)}{O(S p, S e)}=\frac{b C_{1}+C_{2}}{b Q_{1}+Q_{2}}
$$

Met andere woorden de verhouding tussen kosten en opbrengsten op de lijn door de punten $(\mathrm{Sp}, \mathrm{Se})$ en $\left(\mathrm{Sp}^{\circ} ; \mathrm{Se}^{\circ}\right)$ blijft constant.

De $K / O$ verhouding wordt dus, naast de factoren $C_{1}, C_{2}, Q_{1}$ en $Q_{2}$, alleen bepaald door de richtingscoesfficiënt $b_{\text {. }} \mathrm{Nu}$ moet op de ROC-curve het punt gevonden worden, waarvoor geldt dat de bijbehorende $b$ het quotięnt $\left(\mathrm{bC}_{1}+\mathrm{C}_{2}\right) /\left(\mathrm{bQ}_{1}+\mathrm{Q}_{2}\right)$ minimaliseert. Aangetoond kan worden dat dit punt of $[0,1]$ of $[1,0]$ of het punt, waarin de raaklijn aan de $\mathrm{ROC}$-curve vanuit $\left(\mathrm{Sp}^{\circ}, \mathrm{Se}^{\circ}\right)$ de $\mathrm{ROC}$-curve raakt, is (voor bewijswoering hiervan, zie Koning \& Ament, 1988).

\subsection{EEN REKENVOORBEELD}

De gegevens, die benodigd zijn, hebben betrekking op de vollgende onderdelen: 
- gegevens met betrekking tot de ROC-curve,

- gegevens over de kosten- en opbrengstenfactoren.

\section{ROC-curve}

De ROC-curve kan bepaald worden uit de verdeling van zieken en niet-zieken. In dit rekenvoorbeeld zal uitgegaan worden van een ROC-curve, die voldoet aan de navolgende specificaties:

$$
S e=\left(1-S p^{q}\right)^{1 / q}
$$

Door de factor $q$ te laten variëren kunnen symmetrische ROC-curves worden gesimuleerd. Indien $q=1$ wordt de ROC-curve van een waardeloze test gevonden. Naarmate q groter wordt zal de betreffende ROC-curve de perfecte test benaderen. In onderstaande berekeningen is uitgegaan van de waarde 2 voor q.

Voor de berekening is het nodig de dSe/dSp te bepalen, hetgeen kan geschieden met behulp van onderstaande functie:

$$
\frac{d S e}{d S p}=-\left(1-S p^{q}\right)^{(1 / q-1)} \cdot S p^{(q-1)}
$$

\section{De kosten- en opbrengstengegevens}

In onderstaande tabel zijn voor een fictief rekenvoorbeeld de incrementele kosten- en opbrengstengegevens weergegeven. De cijfers zijn zodanig gekozen, dat aan de voorwaarden voldaan is dat de betreffende kostenfunctie een minimum vertoont en de betreffende opbrengstenfunctie een maximum (zie par. 6:4.2). 
Tabel 6.3. Incrementele kosten- en opbrengstengegevens: een fictief rekenvoorbeeld

$\begin{array}{ll}\text { Kosten } & \text { Opbrengsten in QALY } \\ \mathrm{C}_{\mathrm{TP}}=f 300,- & \mathrm{Q}_{\mathrm{TP}}=1 \\ \mathrm{C}_{\mathrm{PP}}=f 300,- & \mathrm{Q}_{\mathrm{FP}}=-0,001 \\ \mathrm{C}_{\mathrm{FN}}=f 5.000,- & \mathrm{Q}_{\mathrm{FN}}=0.01 \\ \mathrm{C}_{\mathrm{TN}}=-f 1.000,- & \mathrm{Q}_{\mathrm{TN}}=0\end{array}$

Hieronder zijn de verschiliende modelspecificaties nog eens samengevat.

De optimale afkappunten van de testen worden als volgt verkregen in de respectievelijke modellen.

Model $1 \frac{\mathrm{dSe}}{\mathrm{dSp}}=-\frac{(1-\mathrm{p})}{\mathrm{p}}$

Model $2 \frac{\mathrm{dSe}}{\mathrm{dSp}}=-\frac{(1-\mathrm{p})}{\mathrm{p}} \frac{\mathrm{C}_{\mathrm{FP}}}{\mathrm{C}_{\mathrm{FN}}}$

Model $3 \frac{\mathrm{dSe}}{\mathrm{dSp}}=+\frac{(1-\mathrm{p})}{\mathrm{p}} \frac{\left(\mathrm{C}_{\mathrm{FP}}-\mathrm{C}_{\mathrm{TN}}\right)}{\left(\mathrm{C}_{\mathrm{TP}}-\mathrm{C}_{\mathrm{FN}}\right)}$

Model $4 \frac{\mathrm{dSe}}{\mathrm{dSp}}=\frac{(1-\mathrm{p})}{\mathrm{p}} \frac{\left(\mathrm{Q}_{\mathrm{Fp}}-\mathrm{Q}_{\mathrm{TN}}\right)}{\left(\mathrm{Q}_{\mathrm{TP}} \mathrm{Q}_{\mathrm{PN}}\right)}$

Model $5 \frac{\mathrm{dSe}}{\mathrm{dSp}}=\frac{(1-\mathrm{p})}{\mathrm{p}} \frac{\left\{\left(\mathrm{Q}_{\mathrm{pp}}-\mathrm{Q}_{\mathrm{TN}}\right) \mathrm{K}(\mathrm{x})-\left(\mathrm{C}_{\mathrm{FP}}-\mathrm{C}_{\mathrm{TN}}\right) \mathrm{O}(\mathrm{x})\right\}}{\left\{\left(\mathrm{Q}_{\mathrm{TP}}-\mathrm{Q}_{\mathrm{PN}}\right) \mathrm{K}(\mathrm{x})-\left(\mathrm{C}_{\mathrm{TP}}-\mathrm{C}_{\mathrm{FN}}\right) \mathrm{O}(\mathrm{x})\right\}}$

Model $6 \frac{\mathrm{dSe}}{\mathrm{dSp}}=\frac{(1-\mathrm{p})}{\mathrm{p}} \frac{\left(\mathrm{U}_{\mathrm{PP}}-\mathrm{U}_{\mathrm{TN}}\right)}{\left(\mathrm{U}_{\mathrm{TP}}-\mathrm{U}_{\mathrm{PN}}\right)}$ 
In de besliskunde wordt een aantal modellen onderscheiden afhankelijk van beslissingscriteria. Model 1 is identiek aan het model waarin het aantal correcte uitspraken wordt gemaximaliseerd. Dit model wordt well aangeduid met max $-\mathrm{p}(\mathrm{C})$ en de beslisser die handelt volgens bovenstaand criterium de max - $p(C)$ observer (Egan, 1975). (In dit model spelen de uitkomsten geen rol.) De overige vijf vermelde modellen zijn voorbeelden van beslissers, die nut willen maximaliseren (Expected Value), maar dit nut kan op verschillende manieren worden gespecificeerd; soms alleen in kosten (model 2 en 3), soms alleen in opbrengsten (model 4) en soms in opbrengsten en kosten (model 5 en 6 ).

Naast deze modellen wordt ook nog wel het Neyman-Pearson besliscriterium onderscheiden. Hierbij wordt een acceptabel niveau van fout positieven gedefinieerd en wordt vervolgens het aantal correcte uitspraken gemaximaliseerd (Miller e.a., 1981).

\section{Resultaten}

In de eerste plaats is het optimale afkappunt bepaald, uitgaande van een a priori kans van $\mathrm{p}=5$. In onderstaande grafiek zijn de punten op de ROC-curve weergegeven, welke als optimaal worden beschouwd bij de diverse modelspecificaties.

Figuur 6.3. Optimale afkappunten bij zes modelspecificaties

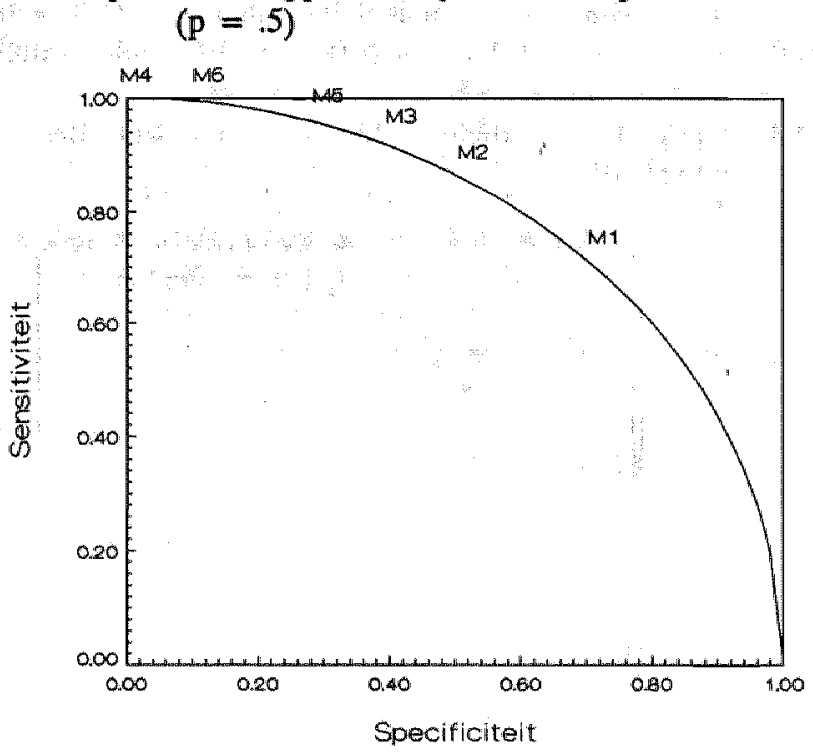

Bij model 5 is hierbij de rekenprocedure gevolgd, waarbij voor ieder mogelijk afkappunt de K/O verhouding is bepaald. Bij model 6 is voor de waarde van de QALY het bedrag $f$ 10.000,- genomen.

De figuur maakt duidelijk dat er grote verschillen zijn afhankelijk van het optimaliseringscriterium. Alle modelspecificaties waarbij met kosten en/of opbrengsten rekening wordt gehouden leiden tot een afkappunt met een hogere sensitiviteit dan de sensitiviteit bij model 1. 
Model 2,3 en 4 zijn in principe onvolledige evaluaties en zijn ter vergelijking weergegeven. Toch zijn dit de modellen die in de literatuur steeds opduiken. Opvallend is het afkappunt met de extreem hoge sensitiviteit indien de opbrengsten worden gemaximaliseerd (model 4). De verhouding tussen de te behalen winst en het eventueel te leiden verlies is in dit voorbeeld hoog ( \pm .001$)$, waardoor een groot aantal FP meldingen toegestaan kan worden. In de praktijk zal de winst behorend bij het terecht behandelen vaak groot zijn ten opzichte van het verlies behorende bij onterechte behandeling. Aangezien de arts intuitief meer geneigd zal zijn om de opbrengsten te maximaliseren (model 4) dan om de kosten te minimaliseren (model 3) is dit een mogelijke werklaring voor het feit dat artsen een hoge sensitiviteit in het algemeen belangrijker vinden dat een hoge specificiteit.

Uit de voorgaande analyses is duidelijk geworden dat de invloed van de a priori kans op het optimale afkappunt groot is. In onderstaande grafiek is deze invloed voor de diverse model-specificaties weergegeven. Voor alle modellen geldt dat naarmate de a priori kans toeneemt het belang van de sensitiviteit toeneemt en dus het belang van de specificiteit afneemt. Voor de modellen $1 \mathrm{t} / \mathrm{m} 4$ en 6 volgt dit rechtstreeks uit de hiervoor weergegeven formules. Voor model 5 is dit echter niet voorspelbaar aangezien de a priori kans mede de hoogte van de rechter term bepaalt. Het is verder frappant dat de grafieken van model 5 en 6 elkaar snijden. Bij lage waarden voor $p(p< \pm .20)$ vergt het $K / O$ criterium een hogere sensitiviteit dan het $O-K$ criterium en het omgekeerde geldt voor hogere waarden van $\mathrm{p}$ (zie onderstaande grafiek).

Figuur 6.4. Optimale sensitiviteit bij zes modelspecificaties naar prevalentie

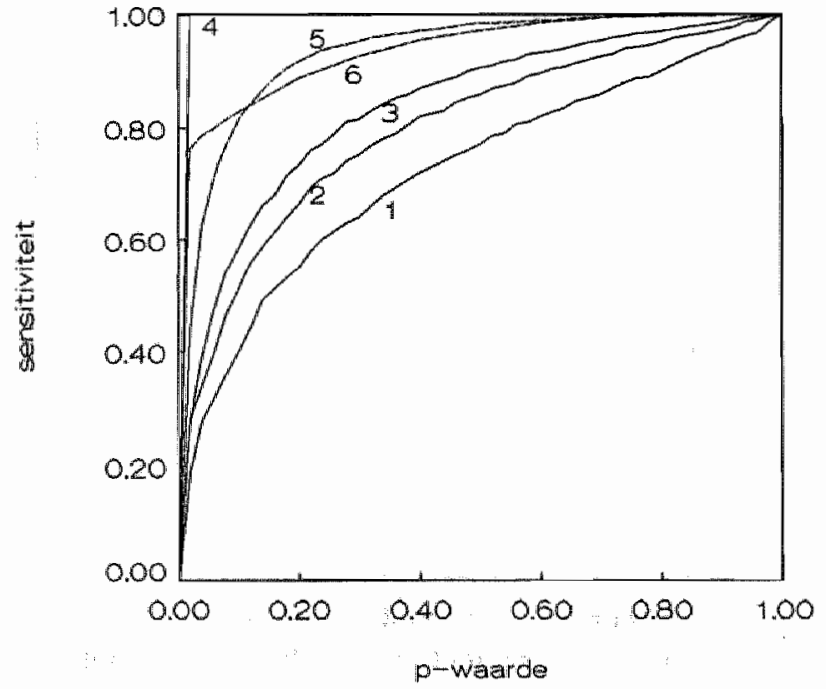

Wordt bij het bepalen van het optimale afkappunt zowel met de opbrengsten als met de kosten rekening gehouden, dan doet zich het volgende dilemma voor. Voor maximalisatie van het nettoverschil tussen opbrengsten en kosten (model 6) is het nodig dat kosten en opbrengsten in eenzelfde eenheid worden uitgedrukt, hetgeen betekent dat de gezondheidswinst c.q. het verlies in geld kan worden uitgedrukt. Acceptabele 
methoden waarmee dit kan geschieden ontbreken (Jones-Lee, 1976; Warner \& Luce, 1982). Het probleem kan omzeild worden door een QALY arbitrair een bepaalde waarde te geven, waarna het optimale afkappunt kan worden bepaald. Nadere bestudering van de specificatie van model 5 maakt duidelijk dat de waarde van de QALY geen invloed heeft op het optimale afkappunt. (De factoren in zowel de teller als de noemer worden met eenzelfde bedrag vermenigvuldigd!) Het optimale afkappunt in model 6 is echter afhankelijk van de waarde van een QALY. In onderstaande tabel is weergegeven hoe het optimale afkappunt in model 6 verschuift onder invloed van de waarde van een QALY.

Tabel 6.4. Sensitiviteit behorende bij optimaal afkappunt, model 6 naar waarde van een QALY (10.000 tot 50.000) en naar a priori kans

$\begin{array}{lccc}\text { Waarde QALY } & \text { Se } & \text { Se } & \text { Se } \\ & p=.1 & p=.2 & p=.3 \\ 10.000 & .63 & .88 & .95 \\ 20.000 & .82 & .95 & .98 \\ 30.000 & .89 & .98 & .99 \\ 40.000 & .93 & .98 & .99 \\ 50.000 & .95 & .99 & .99\end{array}$

Hoe hoger de waarde van een QALY is, des te hoger zal de sensitiviteit van het afkappunt moeten zijn. Bij lage a priori kansen is het optimaal afkappunt zeer gevoelig voor deze waarde (zie tabel). Bij hogere prevalenties blijkt het optimale afkappunt veel stabieler, hetgeen samenhangt met het hoge uitgangsniveau van de sensitiviteit.

Hiervo6r is bewezen dat het optimale afkappunt volgens het criterium K/O ook gevonden kan worden door het snijpunt van (14) en (15) te bepalen en van daaruit de raaklijn te trekken aan de $R O C$-curve.

Uitgaande van bovenstaande gegevens zijn de betreffende functies respectievelijk

$$
\begin{aligned}
& \mathrm{Se}=-.2766 \mathrm{Sp}+1,1277 \\
& \mathrm{Se}=-.0010 \mathrm{Sp}+.0091
\end{aligned}
$$

Het punt waar de betreffende lijnen elkaar snijden heeft de volgende coördinaten : abcis 4,06 en ordinaat +.005 .

In onderstaande figuur is vanuit het betreffende punt de raaklijn getrokken aan de ROC-curve, waarmee de sensitiviteit en specificiteit bepaald is behorende bij het afkappunt waarin de $\mathrm{K} / \mathrm{O}$ verhouding minimaal is. 
Figuur 6.5. Optimaal afkappunt K/O criterium grafisch bepaald

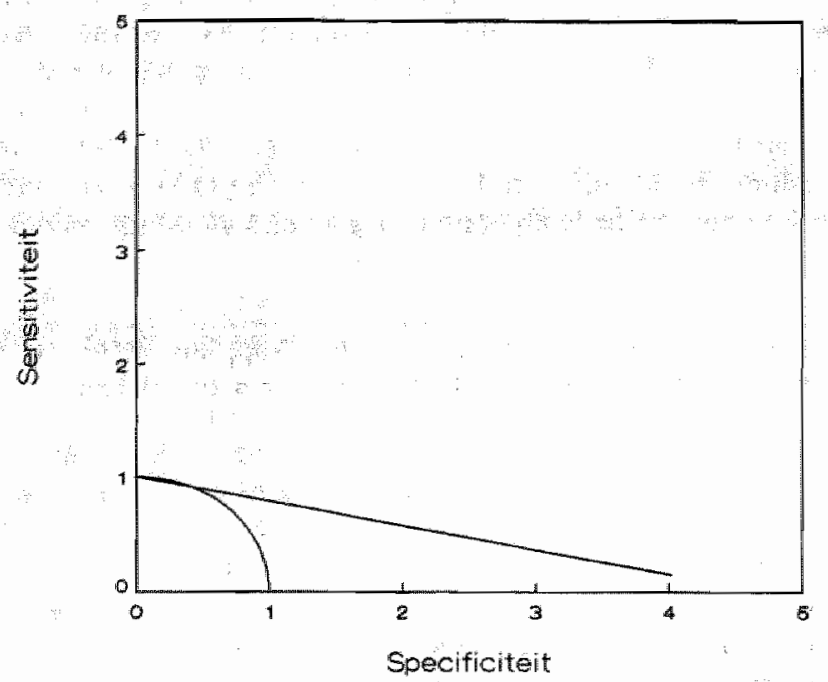

\subsection{BESCHOUWING}

Het bepalen van het optimale afkappunt van een test is gecompliceerd vanwege het feit dat kosten en opbrengsten in verschillende dimensies worden weergegeven. Het minimaliseren van de kosten aan de ene kant, of het maximaliseren van de opbrengsten aan de andere kant is relatief eenvoudig uit te voeren, indien de ROC-curve, de a priori kans en de kosten- en opbrengstenconsequenties bekend zijn.

Optimalisering in economische zin houdt in dat zowel met de opbrengsten als de kosten rekening wordt gehouden. Hiervo6r is aangegeven hoe het optimale afkappunt bepaald kan worden, waarbij een tweetal criteria gehanteerd kunnen worden.

\section{O-K criterium (model 6)}

2. K/O criterium (model 5)

De criteria leiden tot verschillende uitkomsten. Voor iedere a priori kans zullen volgens het eerste criterium QALY's geproduceerd worden tegen een gemiddeld hogere prijs. Bij $\mathrm{p}=.5$ bijvoorbeeld zijn de opbrengsten en kosten in het optimale afkappunt in onderstaande tabel weergegeven: de waarde van een QALY is gesteld op $f 10.000$,-Welke van beide criteria dient in de praktijk als leidraad voor het medisch handelen te gelden?

Passen we de redenering uit 6.4 .3 toe op het voorbeeld uit tabel 6.5 dan blijkt dat voor waardle van $M<f 5.400$ beide criteria tot eenzelfde voorkeur leiden. Aangezien in dit voorbeeld de waarde van een QALY groter is dan $f 5.400$ leiden de beide criteria tot verschillende oplossingen.

Volgens het criterium O-K zijn de QALY's, geproduceerd in het optimale afkappunt, duurder dan de QALY's behorende bij het O/K criterium. Of de QALY's die aldus 
Tabel 6.5. Opbrengsten en kosten bij twee optimaliseringscriteria

$$
\begin{array}{cc}
\text { criterium } & \text { criterium } \\
0-K & \mathrm{~K} / \mathrm{O}
\end{array}
$$

$\begin{array}{lrr}\text { Opbrengst } & 0.495 & 0.485 \\ \text { Kosten } & f 1.533 & f 1.479 \\ \text { K/O } & f 3.097 & f 3.049\end{array}$

geproduceerd worden volgens het $\mathrm{O}-\mathrm{K}$ criterium te duur zijn, hangt af van de opbrengst van alternatieve bestedingen (opportunity costs). De gezondheidswinst bij het $\mathrm{O}-\mathrm{K}$ criterium is weliswaar groter ( .495 tegenover .485$)$ maar daar staan ook hogere kosten tegenover ( $f 3.097$ tegenover $f$ 3.049). De incrementele $\mathrm{K} / \mathrm{O}$ verhouding bedraagt $f 4.800$ per QALY ( $f$ 48/.01). Zolang deze incrementele K/O verhouding beneden de waarde van een QALY ligt is hanteren van een afkappunt volgens het $\mathrm{O} \cdot \mathrm{K}$ criterium de meest efficiënte productiewijze. De waarde wan een QALY die in deze berekening wordt meegenomen symboliseert de opportunity-kosten, aangezien we er vanuit zijn gegaan dat dit het maximum bedrag is waarvoor QALY's mogen worden geproduceerd.

Een volledige economische analyse met betrekking tot het te hanteren afkappunt vergt een groot aantal berekeningen, waarbij zowel van de $\mathrm{K} / \mathrm{O}$ als van de $\mathrm{O}-\mathrm{K}$ benadering gebruik gemaakt moet worden. In de medische praktijk zal er derhalve behoefte bestaan aan een methode waarmee het bepalen van het optimale afkappunt op een meer kwalitatieve wijze kan worden benaderd.

Op de invloed van de hoogte van de a priori kans op het optimale afkappunt is in hoofdstuk 4 reeds ingegaan. Indien de a priori kans laag is, bijvoorbeeld bij screening, dan zal een afkappunt met een hoge specificiteit en een lage sensitiviteit gekozen moeten worden. Het optimum dat op grond van economische overwegingen zou moeten worden gekozen, kan gekenmerkt worden door lage waarden van sensitiviteit ( $\mathrm{Se}= \pm$ .5). Een dergelijke sensitiviteit wordt in de medische praktijk snel te laag bevonden. De arts, gewend aan het oplossen van medische problematiek, zal een screeningsprogramma, waarbij bijvoorbeeld slechts kén op de twee zieken wordt opgespoord, als volstrekt inadequaat beschouwen. Toch zou een dergelijk programma in economisch opzicht wel efficiënt genoemd kunnen worden.

Bij de evaluatie van diagnostische tests en monitoring tests spelen naast de a priori kans ook de verhouding tussen kosten- en opbrengstenconsequenties een rol. In een volledige economische evaluatie met betrekking tot zowel de diagnostische test als ook de monitoring test zouden alle kosten- en opbrengstengevolgen betrokken moeten worden. Eerder is in dit hoofdstuk op het verschil tussen de twee soorten tests ingegaan, waarbij werd vastgesteld dat diagnostische tests primair beoordeeld moeten worden in functie van de te behalen gezondheidswinst, terwijl monitoring tests vaak gezien kunnen worden in functie van kostenbesparing. Dit heeft sommige auteurs ertoe gebracht om model 3 te hanteren in geval van een monitoring test of model 4 voor een diagnostische test. Voorzover de betreffende kosten of opbrengsten nul zijn of nul benaderen, bieden de respectievelijke modellen adequate oplossingen. In de praktijk zal van geval tot geval nagegaan moeten worden in hoeverre aan deze voorwaarden is voldaan. 


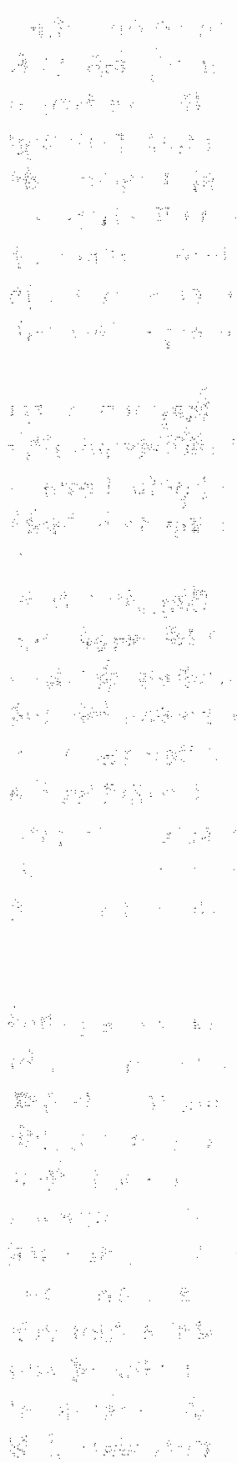




\section{KOSTEN EN OPBRENGSTEN VAN TESTS ${ }^{1}$}

\subsection{INLEIDING}

Het diagnostische proces levert op zichzelf geen eindproduct af; bet is te beschowwen als een intermediair proces. Dit impliceert dat een test beoordeeld dient te worden in relatie tot de uiteindelijk te behalen therapeutische gezondheidswinst. In dit hoofdstuk wordt ingegaan op de methoden, waarmee de waarde van een test kan worden bepaald. Dergelijke methoden kunnen worden gebruikt om in geval van meerdere mogelijkheden het beste alternatief te selecteren. Indien bovendien ook de kosten in de beschouwing worden betrokken, wordt het mogelijk om binnen de gezondheidszorg het testgebruik te betrekken in de prioriteitsstelling met behulp wan economische evaluatietechnieken. Indien de opbrengsten van de test in geld gewaardeerd zijn, dan is met behwip van een besliskundige techniek te bepalen wat de te verwachten opbrengst van de test is. Deze techniek staat bekend onder de term "het bepalen van de waarde van informatie" (Thompson, 1982). De kosten-batenbenadering wordt in de gezondheidszorgsector slechts zeer sporadisch toegepast, met name vanwege het ontbreken van het instrumentarium om gezondheidsverbeteringen in geld te waarderen.

Langs een aantal wegen is getracht om baten in de gezondheidszorg uil te drukken in geld. In de eerste plaats kan het menselijk leven uitgedrukt worden in waarden ontleend aan het economisch verkeer. The Human Capital methode bijvoorbeeld neemt het gemiddelde loon als basis voor een dergelijke berekening. Deze methode wordt terecht binnen de gezondheidszorg niet geaccepteerd vanwege de hieruit resulterende onbillijkheden (Ament, 1979). Door de geringe marktwerking binnen de gezondheidszorg is ook de methode om door nadere bestudering van het "aankoopgedrag" indicaties te verkrijgen over voorkeuren onbruikbaar (methode van de Klaarblijkelijke Voorkeuren, zie bijvoorbeeld Wilms, 1984).

De methode gebaseerd op "Beleden Voorkeuren" wordi algemeen als theoretisch de meest juiste beschouwd, maar de methode heeft in de praktijk niet tot aanvaardbare resultaten geleid (Jones-Lee, 1976; Blauwens, 1985).

Om de reeds bestaande besliskundige technieken op dit punt toch te kunnen gebruiken wordt een kunstgreep toegepast. Er wordt van de veronderstelling uitgegaan dat de uitkomsten van de therapie uitgedrukt kunnen worden in zogenaamde QALY's, naar kwaliteit gecorrigeerde levensjaren. Verschillende soorten gezondheidszorg hebben verschillende aantallen QALY's als uitkomst. Een efficiënt gezondheidszorgsysteem resulteert indien met behulp van kosten-effectiviteitsverhoudingen bepaald wordt, welke delen van het zorgsysteem uitgebreid c.q. ingeperkt moeten worden. Geen dure QALY's produceren als het ook goedkoper kan. Dit principe is te verantwoorden op grond van de schaarste aan beschikbare middelen. Uitgaande van een dergelijke utilitaire grondslag voor de allocatie van middelen binnen de gezondheidszorg, kan een bepaalde maximale waarde bepaald worden van een te produceren QALY. Beneden deze grenswaarde dienen gezondheidszorgprogramma's uitgevoerd te worden, daarboven niet. Over de hoogte van deze specifieke grenswaarde voor een QALY wordt in dit hoofdstuk 
geen uitspraak gedaan. Voorlopig is er nog te weinig bekend over bestaande kosteneffectiviteitsverhoudingen binnen de huidige gezondheidszorg om hierover zinvolle uitspraken te kunnen doen. Dit probleem wordt hier omzeild door een brede marge aan te nemen voor deze maximale waarde van een QALY. Duidelijk is inmiddels wel geworden dat indien alle vormen van gezondheidszorg zouden worden geproduceerd, welke voor minder dan $f 100.000$,- per QALY kunnen worden geproduceerd, de capaciteit van enkele hoogwaardige technologieèn, zoals nierdialyse, open-hartchirurgie, etc. aanzienlijk uitgebreid zou moeten worden, evenals screeningsprogramma's voor borstkanker, hypertensie en cholesterol. Dit impliceert dat de bovengrens van $f$ 100.000,naar alle waarschijnlijkheid ver boven het niveau ligt dat impliciet in de praktijk gehanteerd wordt.

Indien de uitkomsten van gezondheidszorg weer te geven zijn met behulp van QALY's en indien aan cen QALY een bepaald geldbedrag wordt toegekend dan zijn daarmee de uitkomsten in geld uitgedrukt en kunnen de gebruikelijke technieken uit de besliskunde op het diagnostisch proces worden toegepast. Hieronder zal dit worden uitgewerkt. In eerste instantie zal aan de hand van een voorbeeld uit de besliskunde de waarde van informatie worden bepaald en zullen enkele formules worden afgeleid waarmee in een eenvoudige situatie rechtstreeks de waarde van een test kan worden berekend. In paragraaf 7.3 zal deze methode vergeleken worden met andere bestaande methoden waarmee de waarde van een test kan worden bepaald. Vervolgens zal een voorbeeld van een diagnostische test uit de gezondheidszorg worden genomen en met behulp van de ontwikkelde techniek nader worden geanalyseerd (par. 7.4). In paragraaf 7.5 wordt tenslotte de economische evaluatie van het betreffende voorbeeld uitgewerkt.

\subsection{WAARDE VAN INFORMATIE}

In economisch besliskundige leerboeken wordt aandacht besteed aan het berekenen van de waarde van informatie, waarbij het op te lossen probleem er bijvoorbeeld als volgt uitziet: er is een plan om een bepaalde investering te doen. Er bestaat een kans $p$ dat dit een succesvolle investering zal blijken te zijn, maar er is ook een kans (1 - p) dat de investering zal mislukken. Deze kansen zijn de a priori kansen op succes c.q. mislukken. De extra opbrengsten, indien de investering een succes blijkt te zijn, worden

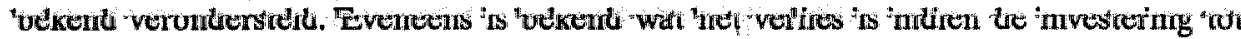
mislukken gedoemd is. Verder is het mogelijk om additionele informatie in te winnen door middel van het verrichten van een proefonderzoek. De nieuwe informatie, die met behulp van het proefonderzoek wordt gegenereerd impliceert niet dat daarna exact bekend is waar men aan toe is. Het onderzoek wordt verondersteld onderhevig te zijn aan fout-positieve en fout-negatieve uitslagen. Wanneer uit het experiment blijkt dat succes verzekerd is, kan in werkelijkheid de investering toch nog mislukken en omgekeerd wanneer het proefonderzoek negatief uitvalt, kan er in werkelijkheid toch sprakè zijn van een succesvolle investering.

\section{Voorbeeld}

$\mathrm{Er}$ is een nieuwe technologie beschikbaar gekomen binnen de gezondheidszorgsector. De overheid wenst een onderzoek te verrichten op grond waarvan besloten kan worden al of niet over te gaan tot invoering van de nieuwe technologie in de gezondheidszorg. De kosten van de nieuwe technologie bedragen $f$ 600,- (een eenmalige uitgave). Indien de technologie succeswol is, dan bedraagt de contante waarde van de opbrengsten 
f1.600,-. De netto-opbrengst is dus gelijk aan $f 1,000,-$ De a priori kans op succes wordt hoger ingeschat dan de kans op mislukken, in dit geval bijvoorbeeld $60 \%$ kans op succes, $40 \%$ kans op mislukken. Nu is het mogelijk om in een bepaalde regio $\mathrm{A}$ een proef te doen. Indien de technologie effectief is, leidt dit in zeven van de tien gevallen tot een positieve uitslag in het proefonderzoek Indien de technologie niet effectief is, is er een kans van $20 \%$ op een positieve uitslag van het proefonderzoek. Daarnaast is het mogelijk om in de regio B een (groter) proefonderzoek te doen, waarmee onomstotelijk kan worden aangetoond of de betreffende technologie succesvol is. Een dergelijk onderzoek levert dus perfecte informatie. In totaal kent een dergelijk probleem vier strategieèn:

1. niets doen,

2. onderzoek proefregio $A$, indien positief dan technologie invoeren, indien negatief dan technologie niet invoeren,

3. onderzoek proefregio $B$, indien positief dan technologie invoeren, indien negatief dan technologie niet invoeren,

4. technologie invoeren zonder proefonderzoek:

Dit probleem kan als volgt in een beslisboom worden weergegeven (zie beslisboom 7.1).

Figuur 7.1.Beslisboom

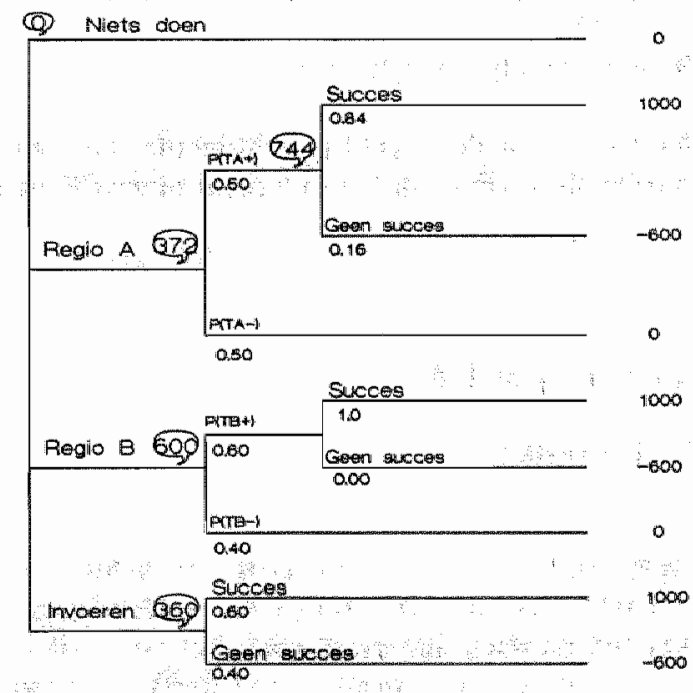

Na het uitvoeren van het experiment zijn de kansen op succes en mislukken niet meer gelijk aan de oorspronkelijke a priori kansen. De kansen zijn nu afhankelijk van de positieve c.q. negatieve testuitslag. Deze kansen kunnen worden berekend met de regel van Bayes (zie hoofdstuk 4).

Invoeren van de technologie zonder het vitvoeren van een experiment levert een verwachtingswaarde op van $.6 \times f 1.000,-.4 \times f 600,-=f 360,-$. Dit alternatief is dus te verkiezen boven het alternatief "niets doen", welk alternatief de verwachtingswaarde heeft van nul. Moet de invoering van de technologie voorafgegaan worden door een experiment in een proefregio? In de beslisboom zijn de zogenaamde omgekeerde kansen en de verwachtingswaarden bij de respectievelijke kansknopen en beslissings- 
knopen vermeld. In dit voorbeeld valt te zien dat de te verwachte opbrengst van een proefonderzoek in gebied A hoger is dan de verwachte waarde van het alternatief "onmiddellijk invoeren" ( $f$ 372,- ten opzichte van $f 360,-$, maar of dit voldoende is hangt af van de investeringskosten voor het experiment. Uit de beslisboom blijkt dat perfecte informatie de verwachtingswaarde laat stijgen van $f 360$,- naar $f 600$,- hetgeen impliceert dat de kosten van het proefonderzoek B niet boven $f$ 240,- mogen liggen. De beste strategie kan bepaald worden indien ook de kosten van proefonderzoeken bekend zijn.

In de beslisboom zien we de verschillende gebeurtenissen in chronologische volgorde met de daarbij behorende kansen van optreden. Indien er sprake is van meerdere experimenteermogelijkheden met eventuele vervolgtests dan wordt een dergelijke beslisboom al snel onoverzichtelijk door de vele takken. Derhalve zal hieronder een enigszins gewijzigde aanpak worden gehanteerd. Bovendien zal het bovenstaande ciffervoorbeeld nu vertaald worden naar het testgebruik binnen de gezondheidszorg.

De arts heeft vier strategieèn ter beschikking:

- niets doen, hetgeen betekent: noch testen noch behandelen,

- test gebruiken met een sensitiviteit van .70 en een specificiteit van .80 ,

- $\quad$ een perfecte test gebruiken waarbij sensitiviteit en specificiteit gelijk zijn aan én,

- behandelen zonder voorafgaande tests.

Verder wordt $U_{1}$ gehanteerd voor de in geld gewaardeerde therapeutische winst en $U_{2}$ voor het in geld gewaardeerde verlies van het onterecht uitvoeren van een behandeling. Hierbij geldt dus:

$$
\begin{aligned}
& \mathrm{U}_{1}=\mathrm{U}_{\mathrm{TP}}-\mathrm{U}_{\mathrm{PN}} \\
& \mathrm{U}_{2}=\mathrm{U}_{\mathrm{PP}}-\mathrm{U}_{\mathrm{TN}} \text { (zie hoofdstuk 6) } \\
& \mathrm{U}_{1}=\text { positief, } \mathrm{U}_{2} \text { is negatief }
\end{aligned}
$$

Met behulp van onderstaande formule kunnen de verwachtingswaarde van de drie strategieen worden bepaald waarbij deze strategieën worden vergeleken met het nulalternatief (niets doen) (de verwachtingswaarde van het alternatief "niets doen" is per definitie nul). Behandelen zonder voorafgaande test heeft als verwachtingswaarde:

$$
\mathrm{E}(\mathrm{U})=\mathrm{p} \mathrm{U}_{1}+(1-\mathrm{p}) \mathrm{U}_{2}
$$

De verwachtingswaarde van het alternatief "testen" is:

$$
E\left(U_{\nu}\right)=\operatorname{Sep} U_{1}+(1-S p)(1-p) U_{2}
$$

en bij gebruik van een perfecte test wordt de verwachtingswaarde:

$$
E\left(U_{p}\right)=p U_{1}
$$


In het cijfervoorbeeld dat hiervoor gebruikt werd geldt: $E(U)=f 360,-E\left(U_{1}\right)=f 372$, en $\mathrm{E}\left(\mathrm{U}_{\mathrm{p}}\right)=f 600,-$ Deze resultaten stemmen overeen met de resultaten verkregen met behulp van de beslisboombenadering. Wordt in de formule (7.2) voor sensitiviteit en specificiteit éen ingevuld, waarden behorende bij een perfecte test, dan wordt formule (7.3) verkregen. Formule (7.1) en (7.3) zijn aan elkaar gekoppeld, doordat bij een perfecte test de verliessituatie wordt vermeden en dit verlies is gelijk aan het tweede stuk uit formule (7.1): $(1-\mathrm{p}) \mathrm{U}_{2}$.

Met behulp van deze formules kunnen op relatief eenvoudige wijze de respectievelijke verwachtingswaarden van de drie alternatieven worden bepaald. In figuur 7.2 zijn deze respectievelijke verwachtingswaarden voor alle waarden van $p$ tussen nul en eén weergegeven.

Figuur 7.2. Verwachtingswaarden strategieën gegeven a priori kans

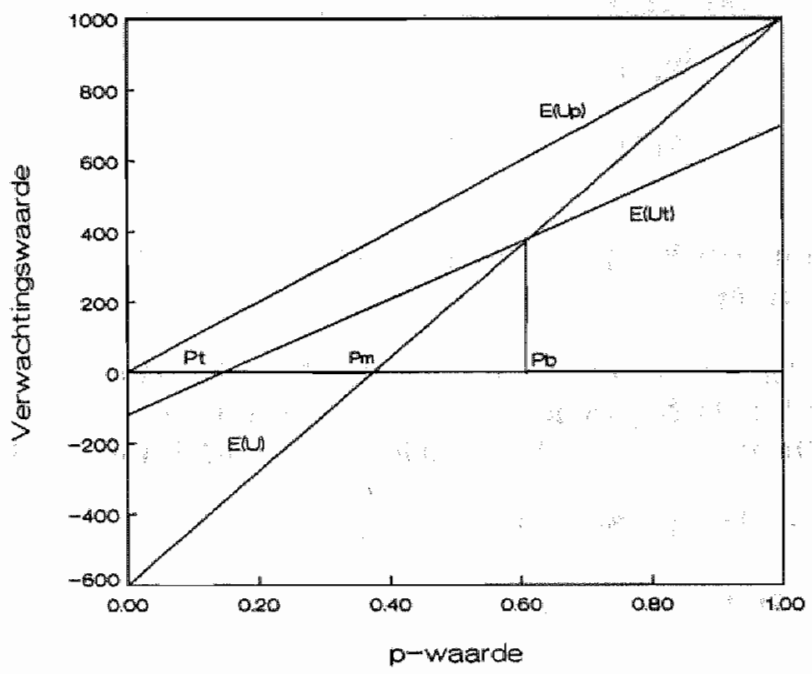

Bij een a priori kans van nul leidt behandelen zonder voorafgaande test tot een verlies van $f 600, \ldots$. Perfecte informatie maakt het mogelijk deze verliessituatie te vermijden $\left(E\left(U_{p}\right)=0\right)$. Bij $p=1$ is de verwachtingswaarde van de perfecte informatie per definitie gelijk aan de verwachtingswaarde zonder extra informatie. Indien de sensitiviteit en specificiteit niet gelijk zijn aan éen, zullen er fout-positieve en fout-negatieve witslagen optreden, hetgeen de potentiële opbrengst reduceert. Bij iedere $p$-waarde is de te verwachten opbrengst van het testalternatief geringer dan het alternatief waarbij de perfecte test wordt ingeschakeld. Uit de formules van de verwachtingswaarden blijkt dat er sprake is van lineaire relaties, hetgeen impliceert dat de lijnen $E(U)$ en $E\left(U_{T}\right)$ elkaar snijden. Het snijpunt vindt plaats in $\mathrm{p}=.61$. Vór dit snijpunt is de verwachtingswaarde van de test hoger dan het alternatief zonder test. Daarna geldt het omgekeerde. Tevens blijkt dat er ook een gebied van p-waarden is waarvoor geldt dat niets doen een hogere verwachtingswaarde heeft dan $\mathrm{E}\left(\mathrm{U}_{\mathrm{T}}\right): 0<\mathrm{p}<.15$. 
De extra opbrengst van de testsirategieën ten opzichte van de alternatieven "niets doen" c.q. "onmiddellijk behandelen" kunnen ook apart worden weergegewen. Daarbij speelt de a priori kans $\left(\mathrm{P}_{\mathrm{m}}\right)$ waarvoor geldt dat de verwachtingswaarden van de alternatieven "niets doen" en "onmiddellijk behandelen" gelijk zijn aan elkaar, een essentiële rol. Voor a priori waarden kleiner dan $\mathrm{p}_{\mathrm{m}}$ worden de teststrategieẽn vergeleken met het alternatief "niets doen", woor waarden boven $\mathrm{p}_{m}$ met het alternatief "onmiddellijk behandelem. De extra opbrengst van de teststrategieen ten opzichte van beide andere strategieen zullen respectievelijk worden aangeduid met W(P) (incrementele opbrengst van de perfecte test) en W(T) (incrementele opbrengst van de test).

De waarde van de perfecte test $W(P)$ kan als volgt worden bepaald. Het maximum van de functie $W(P)$ wordt bereikt voor de waarde van $p$, waarbij geldt:

$$
\mathrm{p}_{\mathrm{m}}=\left(-\mathrm{U}_{2}\right) /\left(\mathrm{U}_{1}-\mathrm{U}_{2}\right)
$$

Dit wordt bereikt door de $\mathrm{E}(\mathrm{U})=0$ te stellen (zie formule 7.1).

$$
\begin{array}{ll}
\text { Voor } \mathrm{p}<\mathrm{p}_{\mathrm{m}} & \mathrm{W}(\mathrm{P})=\mathrm{p} \mathrm{U} \\
\text { Voor } \mathrm{p}>\mathrm{p}_{\mathrm{m}} & \mathrm{W}(\mathrm{P})=-(1-\mathrm{p}) \mathrm{U}_{2}
\end{array}
$$

De waarde van de test $W(T)$ kan bepaald worden met de volgende formules.

Er zijn drie overgangen van a priori kansen belangrijk:

- $\quad \mathrm{p}_{y}$ beneden deze waarde heeft "niets doen" de woorkeur,

- $\quad \mathrm{P}_{\mathrm{m}}$, hier bereikt de waarde van de test zijn maximum,

- $\quad \mathrm{P}_{b}$, de drempel voorbij welke onmiddellijk behandelen de voorkeur verdient.

De formules voor deze waarden zijn als volgt:

$$
\begin{aligned}
& \mathrm{p}_{\mathrm{t}}=\frac{\mathrm{U}_{2}(\mathrm{Sp}-1)}{\mathrm{SeU}_{1}+\mathrm{U}_{2}(\mathrm{Sp}-1)} \\
& \mathrm{p}_{\mathrm{m}}=\frac{-\mathrm{U}_{2}}{\mathrm{U}_{1} \cdot \mathrm{U}_{2}} \\
& \mathrm{p}_{\mathrm{b}}=\frac{-\mathrm{SpU}_{2}}{\mathrm{U}_{1}(1-\mathrm{Se})-\mathrm{SpU}_{2}}
\end{aligned}
$$

$\mathrm{Nu}$ gelden de volgende vergelijkingen:

$$
0<\mathrm{p}<\mathrm{p}_{\mathrm{t}} \quad \mathrm{W}(\mathrm{T})=0
$$




$$
\begin{array}{ll}
\mathrm{p}_{\mathrm{t}}<\mathrm{p}<\mathrm{p}_{\mathrm{m}} & \mathrm{W}(\mathrm{T})=\mathrm{E}\left(\mathrm{U}_{\mathrm{l}}\right)=\mathrm{SepU}_{1}+(1-\mathrm{Sp})(1-\mathrm{p}) \mathrm{U}_{2} \\
\mathrm{p}_{\mathrm{m}}<\mathrm{p}<\mathrm{p}_{\mathrm{b}} & \mathrm{W}(\mathrm{T})=\mathrm{E}\left(\mathrm{U}_{\mathrm{t}}\right)-\mathrm{E}(\mathrm{U})=(\mathrm{Se}-1) \mathrm{pU}_{1}-(\mathrm{Sp})(1-\mathrm{p}) \mathrm{U}_{2} \\
\mathrm{p}_{\mathrm{b}}<\mathrm{p}<1 & \mathrm{~W}(\mathrm{~T})=0
\end{array}
$$

In onderstaande figuur 7.3 zijn de incrementele verschillen van de teststrategieên weergegeven.

Figuur 7.3. Incrementele opbrengst van perfecte informatie $W(P)$ en test W(T)

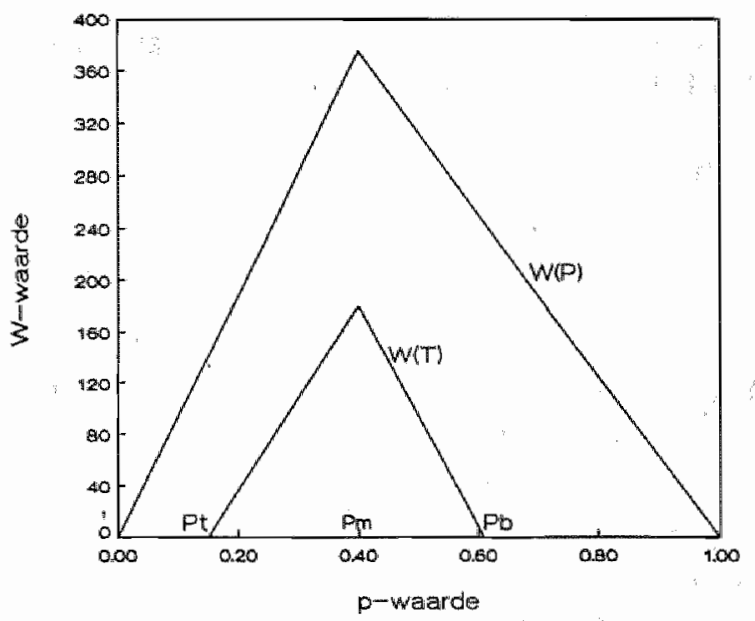

In paragraaf 7.3 zal deze benadering worden vergeleken met de methoden van Pauker \& Kassirer en Van Eeckhoudt e.a. Nu reeds kan gesteld worden dat het experiment of proefonderzoek waarbij er mogelijk sprake is van fout-positieve en fout-negatieve uitslagen slechts in een beperkt gebied van a priori kansen een positieve incrementele opbrengst vertoont. In het voorbeeld is dit het gebied: .14 $<\mathrm{p}<.61$. Voor $\mathrm{p}$-waarden kleiner dan .14 heeft "niets doen" de voorkeur. Voor p-waarden groter dan "61 heeft. invoeren van de betreffende technologie zonder verdere experimenten de voorkeur, waarbij overigens nog de eventuele kosten van de test in de beschouwing betrokken moeten worden (zie hierna).

Er zijn vele combinaties van sensitiviteit en specificiteit waarvoor geldt, dat de werwachtingswaarde van een test kleiner is dan de verwachtingswaarde behorende bij het invoeren van de behandeling zonder test. Interessant zijn die combinaties van sensitiviteit en specificiteit waarvoor geldt dat de verwachtingswaarden van beide strategieën gelijk zijn aan elkaar, met andere woorden waarvoor de gelijkheid geldi: $W(T)=0$. Met behulp hiervan kan worden aangegeven of een bepaalde combinatie van sensitiviteit 
en specificiteit leidt tot een positieve incrementele opbrengst. Daarbij kan onderscheid gemaakt worden in twee soorten beslissingen.

Hiervoor is reeds aangeduid dat voor $\mathrm{p}<\mathrm{p}_{\mathrm{m}}$ "niets doen" beter is dan "onmiddellijk behandelen". Voor het alternatief "uitwoeren van de test" behoeft dan slechts nagegaan te worden of "testen" beter is dan "niets doen".

Uit (7.8) volgt dat deze beide strategieën tot eenzelfde verwachtingswaarde leiden indien geldt:

$$
\mathrm{Se}=\frac{(1-\mathrm{p})}{\mathrm{p}} \frac{\mathrm{U}_{2}}{\mathrm{U}_{1}} \mathrm{Sp}-\frac{(1-\mathrm{p})}{\mathrm{p}} \frac{\mathrm{U}_{2}}{U_{1}} \quad \mathrm{p}<\mathrm{p}_{\mathrm{m}}
$$

Voor $\mathrm{p}>\mathrm{p}_{\mathrm{\omega}}$ geldt dat "onmiddellijk behandelen" beter is dan "niets doen" en behoeft de teststrategie slechts vergeleken te worden met het alternatief "onmiddellijk behandelen":

Uit (7.9) volgt: "uitvoeren van een test" heeft eenzelfde verwachtingswaarde als "onmiddellijk behandelen" indien geldt:

$$
\mathrm{Se}=\frac{(1-p)}{p} \frac{U_{2}}{U_{1}} \mathrm{Sp}+1 \quad \mathrm{p}>\mathrm{p}_{m}
$$

Voor $\mathrm{p}<\mathrm{p}_{\mathrm{m}}$ geldt: $\frac{(1-\mathrm{p})}{\mathrm{p}} \frac{\mathrm{U}_{2}}{\mathrm{U}_{1}}<-1$

en voor $p>p_{m}$ geldt: $\frac{(1-p)}{p} \frac{U_{2}}{U_{1}}>-1$

Stellen we $R=\frac{(1-p)}{p} \frac{U_{2}}{U_{1}}$

dan kunnen de bovenstaande formules als volgt worden samengevat

$$
\begin{array}{ll}
\text { Se }=\mathrm{R} \mathrm{Sp}-\mathrm{R} & \text { indien } \mathrm{R}<-1 \text { (of } \mathrm{p}<\mathrm{p}_{\mathrm{m}} \text { ) } \\
\mathrm{Se}=\mathrm{R} \mathrm{Sp+1} & \text { indien } \mathrm{R}>-1 \text { (of } \mathrm{p}>\mathrm{p}_{\mathrm{m}} \text { ) }
\end{array}
$$

Ook is het mogelijk om in een eenvoudige grafiek de tot nu toe behaalde resultaten met betrekking tot het cijfervoorbeeld weer te geven (zie figuur 7.4). 
Figuur 7.4. Combinaties van sensitiviteit en specificiteit waarwoor geldt $\mathrm{W}(\mathrm{T})=0$

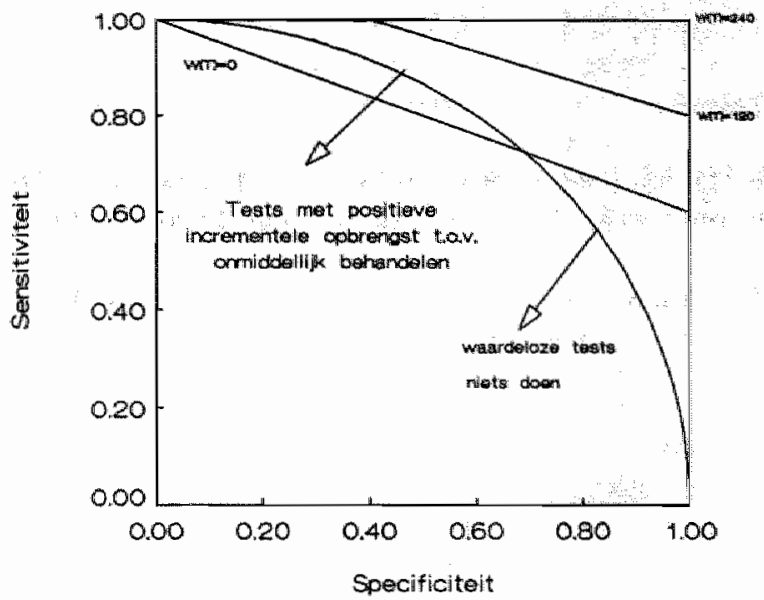

Voor $\mathrm{p}=.6, \mathrm{U}_{1}=1000$ en $\mathrm{U}_{2}=-600$ heeft de $\mathrm{R}$ de waarde $-2 / 5$. De lijn, die alle tests verbindt, waarvoor geldt dat de extra informatie gelijk is aan 0 voldoet nu aan

$$
\mathrm{Se}=-2 / 5 \mathrm{Sp}+\mathbb{1}
$$

Combinaties van sensitiviteit en specificiteit welke zich onder deze lijn bevinden, zijn waardeloos. Tests die zich boven de lijn bevinden, bevatten positieve incrementele opbrengst.

Indien de ROC-curve bekend is kan met behulp van bovenstaande methode aangegeven worden welk gedeelte van de ROC-curve gegeven de $p, \mathrm{U}_{1}$ en $\mathrm{U}_{2}$ waarden buiten beschouwing kan blijven.

Uit het bovenstaande kan de navolgende aanvulling op een bekende beslisregel worden geformuleerd. In de literatuur wordt vaak geformuleerd dat het uitvoeren van de test dient te geschieden indien geldt, dat de likelihood ratio van de positieve testuitslag groter is dan de bovenvermelde factor $\mathbf{R}$ (voorzien van een min-teken) dus:

$$
L(+)=\frac{S e}{1-S p}>-R
$$

De test dient niet uitgevoerd te worden indien geldt:

$$
L(+)<-R \quad \text { (zie bijwoorbeeld Egan (1975); Doubilet (1983)). }
$$


Aangezien $U_{1}$ positief en $U_{2}$ negatief is, zal $R$ waarden kunnen aannemen tussen nul en $-\infty$. Hieronder zullen de twee gebieden:

1) $-\infty<R<-1$

2) $-1<R<0$

apart worden bekeken.

Geldt woorwaarde (1) dan geldt voor de nullijn vergelijking (7.13). De betreffende lijn gaat dan door het punt waar $\mathrm{Se}=0 \mathrm{en} \mathrm{Sp}=1$ (zie bijvoorbeeld figuur 7.5).

Figuur 7.5. Combinatie van Se en Sp met voorwaarde $W(t)=0$

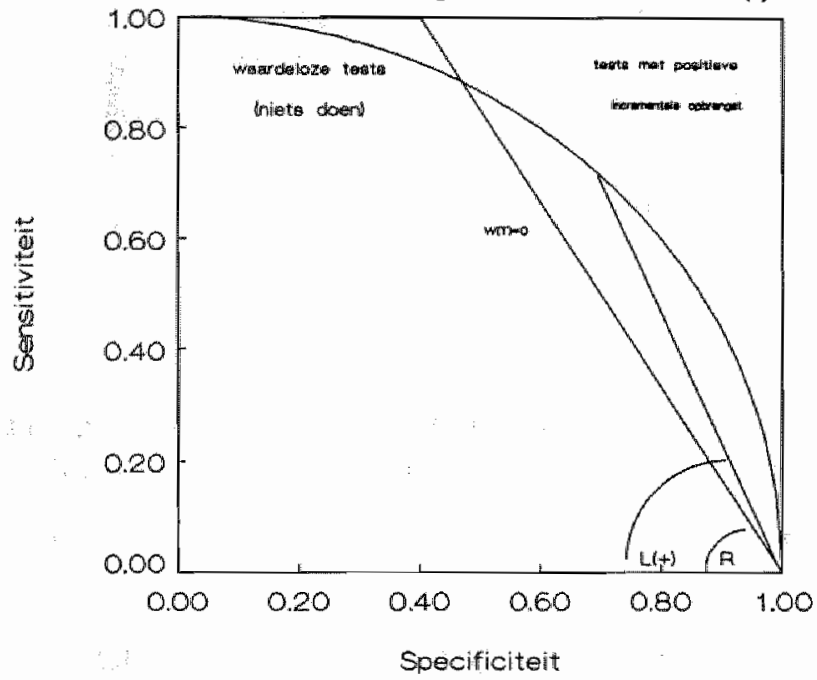

Wordt een willekeurig punt op de ROC-curve gekozen, dan kan de $L(t)$ worden weergegeven door de (negatieve) richtingscoëfficiënt van de lijn door het betreffende punt en het punt $(1,0)$. Indien geldt: $L(+)>-R$ betreft het een punt op de ROCcurve, met een positieve incrementele opbrengst. Dit stemt overeen met bovenvermelde beslisregel.

$R>-1$ kan ook geschreven worden als $\mathrm{p}<-\mathrm{U}_{2} /\left(\mathrm{U}_{1}-\mathrm{U}_{2}\right)$ ofwel $\mathrm{p}<\mathrm{p}_{\mathrm{m}^{*}}$ Hieruil blijkt dat de beslisregel gebruikt kan worden in het gebied van a priori kansen waarden aannemen tussen $p_{t}$ en $p_{m}$.

Geldt echter formule $(7.14)$ (omdat $-1<\mathrm{R}<0$ ) dan gaat de nul-lijn $(\mathrm{W}(\mathrm{T})=0$ ) door het punt waar $\mathrm{Se}=1$ en $\mathrm{Sp}=0$. Een voorbeeld hiervan is te vinden in de voorafgaande figuur 7.4. Ook nu wordt de ROC-curve verdeeld in twee gebieden, een met een positieve opbrengst van de test en een met de negatieve opbrengst. Uit de figuur blijkt dat in het gebied met positieve opbrengsten geldt:

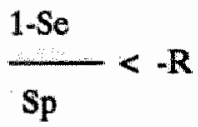




\section{1-Se \\ De factor - kan ook geschreven worden als L( $)$ (zie hoofdstuk 4), \\ $\mathrm{Sp}$}

In dit geval blijkt dus met name de likelihood ratio van een negatieve testuitslag van belang. In de driehoek die de incrementele opbrengst W(T) van de test bevat (zie figuur 7.3), is in het stijgende gedeelte de positieve testuitslag van belang, terwijl in het dalende gedeelte de negatieve testuitslag van belang is.

Dit is ook op een andere wijze nog te verwoorden. Zonder het testalternatief zou de optimale beslissing zijn:

- niets doen voor $\mathrm{p}<\mathrm{p}_{\mathrm{m}}$

- behandelen voor $\mathrm{p}>\mathrm{p}_{\mathrm{m}}$

Met de test worden in het gebied $\mathrm{p}_{\mathrm{t}}<\mathrm{p}<\mathrm{p}_{\mathrm{m}}$ alsnog de testpositieven wel behandeld. In dit gebied wordt dus extra opbrengst verkregen op grond van de testpositieven. In het gebied $\mathrm{p}_{\mathrm{m}}<\mathrm{p}<\mathrm{p}_{\mathrm{b}}$ zou zonder de test iedereen behandeld worden. Met de test wordt een uitzondering gemaakt voor de negatieve testuitslagen die alsnog uitgesloten worden van behandeling. In het betreffende gebied is een negatieve testuitsllag van belang. De volledige beslisregel luidt dan ook:

Voer de test uit:

Voor $\mathrm{p}_{\mathrm{t}}<\mathrm{p}<\mathrm{p}_{\mathrm{m}}$, indien $\mathrm{L}(+)>-\mathrm{R}$

Voor $\mathrm{p}_{\mathrm{m}}<\mathrm{p}<\mathrm{p}_{\mathrm{b}}$, indien $\mathrm{L}(-)<\cdot \mathrm{R}$

In onderstaand overzicht worden de hoofdlijnen van bovenstaande analyse nog eens samengevat.

$\mathrm{p}_{\mathrm{t}}<\mathrm{p}<\mathrm{p}_{\mathrm{m}} \quad \mathrm{p}_{\mathrm{m}}<\mathrm{p}<\mathrm{p}_{\mathrm{b}}$

1. Van belang is met name:

2. Van belang is:

3. Voor $\mathbf{R}$ geldt:

4. Test is zinvol indien:

5. Specificatie van de lijn, welke combinaties van sensitiviteit en specificiteit met opbrengst nul verbindt:

6. Vergeleken wordt: positieve

testuitslag hoge Sp

$\mathbf{R}<-1$

$L(+)>-R$

$\mathrm{L}(-)<-\mathrm{R}$

hoge Se

$\mathrm{R}>-1$ negatieve

testuitslag

$\mathrm{Se}=\mathrm{RSp}-\mathrm{R}$

$\mathrm{Se}=\mathrm{RSp}+1$

Testen t.o.v.

Testen t.ov. niets doen onmiddellijk

behandelen 
Hierboven is afgeleid dat alle combinaties van sensitiviteit en specificiteit welke incrementele opbrengsten laten zien gelijk aan nul, gelegen zijn op een rechte 1 lijn, waarvan de specificatie gegeven wordt door formule (7.11) of (7.12). Op identieke wijze kan berekend worden dat ook combinaties van sensitiviteit en specificiteit welke resulteren in cen bepaalde incrementele opbrengst (C) gelegen zijn op een rechte lijn met als specificatie:

$$
\begin{array}{ll}
\mathrm{Se}=\mathrm{RSp}-\mathrm{R}+\frac{\mathrm{C}}{\mathrm{pU_{i }}} & \text { voor } \mathrm{p}_{\mathrm{t}}<\mathrm{p}<\mathrm{p}_{\mathrm{m}} \\
\mathrm{Se}=\mathrm{RSp}+1+\frac{\mathrm{C}}{\mathrm{pU_{1 }}} \quad \text { voor } \mathrm{p}_{\mathrm{m}}<\mathrm{p}<\mathrm{p}_{\mathrm{b}}
\end{array}
$$

In figuur 7.4 is de lijn behorende bij $W(T)=120$ weergegeven met behulp wan formule (7.17). Met dezelfde formule kan worden aangetoond dat in het punt waar sensitiviteit en specificiteit gelijk zijn aan $1 \mathrm{de} W(T)=240$. Dit is tevens de maximaal haalbare opbrengstl

In het voorafgaande hoofdstuk zijn deze lijnen aangeduid met "isoquanten". Het bovenstaande betekent dat een bepaalde toename van sensitiviteit of specificiteit altijd leidt tot een bepaalde toename in de opbrengst, onafhankelijk van de uitgangswaarde van de sensitiviteit of specificiteit. Deze isoquanten maken nogmaals duidelijk dat het optimale afkappunt op de ROC-curve kan worden gevonden door de raaklijn met richtingscoeffficient $-R$ te trekken aan de ROC-curve. Het betreffende raakpunt ligt, namelijk op de hoogste isoquant.

Tot nu toe zijn we in het voorbeeld uitgegaan van een bepaalde waarde voor $p, U_{1}$ en $\mathrm{U}_{2}$. Dit zijn de factoren die de richtingscoëfficiënt van de nullijn bepalen. Variëren $p$, $U_{1}$ en $U_{2}$ dan verandert de richtïngscoëfficiënt van de nullijn en daarmee de afstand van de verschillende combinaties tot die nullijn. Ter illustratie een voorbeeld. Vergelijken we twee combinaties van sensitiviteit en specificiteit, bij verschillende a priori kansen dan kunnen voorgaande formules worden toegepast. In de volgende tabel zijn de resultaten weergegeven. 
Tabel 7.1. : Waarde van een test bij verschillende a priori kansen

Test $1 \mathrm{Se}=9 \mathrm{Sp}=.7$

Test $2 \mathrm{Se}=7 \mathrm{Sp}=9$

$p=.6$

(zie figuur 7.6a) (zie figuur 7.6b)

$\mathrm{U}_{1}$

$\mathrm{U}_{2}$

$\mathbf{R}$

nullijin

$W\left(T_{1}\right)$

1.000

1.000

$-600$

- 600

- 0,4

$-\quad 2,4$

$\mathrm{Se}=-0,4 \mathrm{Sp}+1$

$\mathrm{Se}=-2,4 \mathrm{Sp}+2,4$

$\mathrm{W}\left(\mathrm{T}_{2}\right)$

36

36

92

Grafisch kan dit als volgt worden weergegeven.

Figuren 7.6a en 7.6b. Waarde van tests bij verschillende a priori kansen
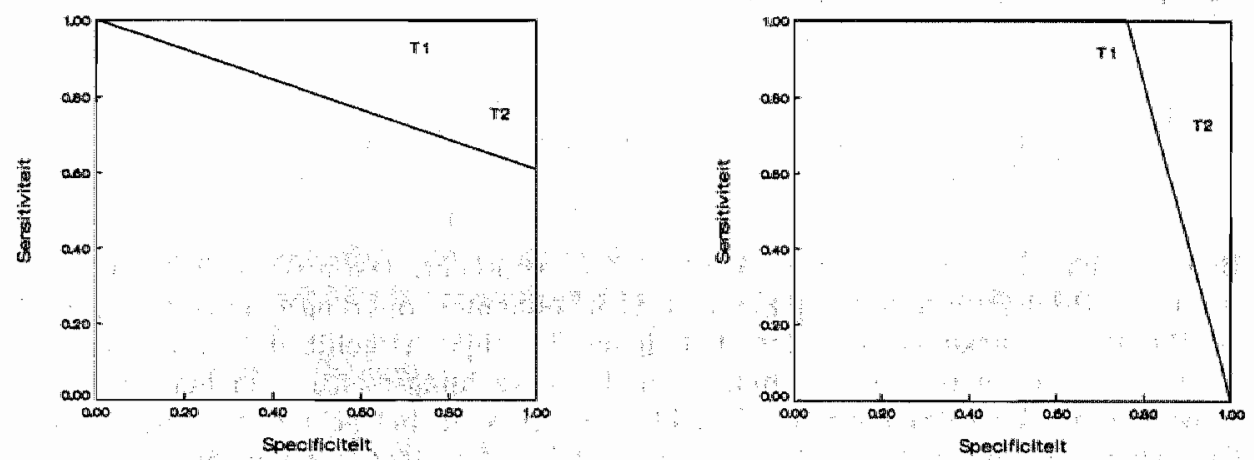

Afhankelijk van de waarde van de a priori kans is test 1 dan wel test 2 de test met de hoogste incrementele opbrengst. Verder maakt deze methode het mogelijk om tests te evalueren los van de onderliggende ROC-curve.

\subsection{VERGELIJKING ENKELE METHODEN}

De besliskundige benadering ter bepaling van de waarde van een test, zoals die hiervoor beschreven werd, is vergelijkbaar met alternatieve benaderingen. Hieronder zal aan een aantal benaderingen aandacht worden geschonken.

1. de drempelanalyse van Pauker \& Kassirer,

2. de driehoek van Eeckhoudt,

3. optimale afkappunt bij continue tests (Doubilet). 


\section{Drempelanalyse van Pauker \& Kassirer}

Pauker \& Kassirer (1975) ontwikkelden een methodiek waarmee de overgang kan worden bepald in termen van a priori kans tussen de alternatieven "niets doen" en onmiddellijk behandelen". De methodiek is op zich een fraai voorbeeld van een drempelanalyse.

Indien bepaalde wariabelen in een model een groot aantal waarden kunnen aannemen, is het interessant on van tevoren reeds te kunnen bepalen bij welke waarden van deze variabelen het ene alternatief prevaleert bowen het andere alternatief. Stel de arts heeft slechts de keuze tussen

\section{- behandelen en \\ - niet behandelen.}

Het behandelen van een persoon die ziek is, levert naar verwachting een bepaalde hoeveelheid gezondheidswinst op $\left(U_{1}\right)$, terwijl behandelen van iemand die niet ziek is gepaard gaat met een verlies aan gezondheid $\left(\mathrm{U}_{2}\right)$. De drempelwaarde voor de a priori kans kan bepaald worden door de verwachtingswaarde van de alternatieven aan elkaar gelijk te stellen.

De drempelwaarde $p_{m}$ is gelijk aan:

$$
\mathrm{p}_{\mathrm{m}}=\frac{-\mathrm{U}_{2}}{\mathrm{U}_{1}-\mathrm{U}_{2}}
$$

Beneden deze drempel heeft niet behandelen de voorkew $r$, daarboven is behandelen te verkiezen. $\mathrm{Bij}$ deze waarde van $\mathrm{p}$ bereiken de incrementele opbrengsten van tests (W(T) en $W(P)$ ) hun maximale waarden. Uit figuur 7.2 blijkt namelijk dat deze maximale waarden worden bereikt in het punt waar de verwachtingswaarde wan het alternatief "uitvoeren zonder extra informatie" gelijk aan nul is. In het gebied waar de a priori kans kleiner is dan $\mathrm{p}_{\mathrm{m}}$ wordt de teststrategie vergeleken met "niets doen", voorbij dit punt wordt de vergelijking gemaakt met de strategie "onmiddellijk uitvoeren".

In 1980 hebben Pauker \& Kassirer een vervolg op deze drempelanalyse gepubliceerd, waarbij met name de drempelwaarde ten aanzien van het all of niet verrichten van een diagnostische test in de beschouwing werd betrokken. Hierdoor ontstaan twee drempels: de drempel tussen "niet behandelen" en "verrichten van een diagnostische test" ( $\mathrm{p}_{\text {J }}$ ) en de drempel die de scheiding aangeeft tussen de alternatieven "testen" en "onmiddellijk behandelen" $\left(p_{b}\right)$.

De formules voor de berekening van de respectievelijke drempels zijn identiek aan de hiervoor gegeven formules $(7.4)$ en $(7.6)$ (met uitzondering van factor $Q_{\downarrow}$ ). In de voorgaande analyse wordt ervan uitgegaan dat de betreffende factor is verdisconteerd in de factoren $U_{1}$ en $U_{2}$ terwijl Pauker \& Kassirer de factor expliciet in de formule benoemen. 
Pauker \& Kassirer concluderen dat hel gebied waar de test het beste alternatief vormi groter wordt

naarmate de sensitiviteit en specificiteit van de test hoger zijn en/of naarmate de risico's verbonden aan de test geringer $z$ iljn.

Door deze benadering wordt de aandacht van de arts gericht op de potentiele opbrengst en risico's van de alternatieven. Tests met een hoger risico voor de patient kunnen slechts dan worden toegepast, indien de potentiele opbrengst veel groter is dan het eraan verbonden risico.

Bovenstaande benadering van de drempels heeft een "normatief" karakter, Gegeven de sensitiviteit en specificiteit en de kosten van de test, moet bij een bepaalde a priori kans een bepaalde strategie gevolgd worden. Een interessante toepassing van deze drempelanalyse, die een meer descriptieve benadering genoemd kan worden, is te vinden bij Eisenberg \& Hershey (1983). Het doel van dit onderzoek is het bepalen vam de drempels op basis van door artsen genomen beslissingen. Uitgaande van een bepaalde (hypothetische) patiënt is aan een aantal artsen gevraagd een schatting te geven van de a priori kans en vervolgens aan te geven welke strategie zou worden gevolgd. Daarna is nieuwe informatie verstrekt over de patient en is opnieuw gevraagd de kans op de ziekte in te schatten en de optimale strategie aan te geven. De combinatie van de a priori en de a posteriori kansen en de genomen beslissingen leverde intervalschattingen op over de hoogte van de gehanteerde behandeldrempels.

Recent zijn stochastische methoden ontwikkeld om drempelanalyses uit te voeren (Greenes e.a., 1984). Indien de cumulatieve kans verdeling van de drempels bekend is, kan berekend worden, op grond van de a priori kans, de sensitiviteit en specificiteit, hoe groot de kans is dat de a posteriori kans deze drempell overschrijdt. Methoden die hierop gebaseerd zijn, zijn echter niet toepasbaar in meer complexe testsituaties (Hartz e.a., 1986). Om deze reden lijkt bespreking ervan in dit kader overbodig.

\section{De driehoek van Eeckhoudt}

Bij de methode wan Eeckhoudt wordt niet alleen het gebied van p-waarden zichtbaar waarbinnen de teststrategie optimaal is, maar wordt tevens aangegeven "hoeveel" winst in gezondheid kan worden behaald ten opzichte van de strategieèn "niets doen" en "onmiddellijk behandelen" waarbij de waarde van een perfecte test de maximale winst gegeven een bepaalde p representeert (Eeckhoudt e.a., 1984).

De waarde van een test kan worden weergegeven door middel van een driehoek, een resultaat dat volledig overeenstemt met de voorafgaande benadering.

De onderlinge vergelijking van de methoden laat zien dat:

de hoekpunten van de driehoek van Eeckhoudt samen vallen met de testrespectievelijk behandeldrempel van Pauker \& Kassirer,

de top van de driehoek wordt bereikt bij een p-waarde, waarbij nu in de eerste benadering van Pauker \& Kassirer de overgang plaatsvindt tussen de alternatieven "niets doen" en "behandelen", dat wil zeggen $p=-U_{2}\left(U_{1}-U_{2}\right)$.

Ook de perfecte test zall de maximale waarde bereiken bij dezelfde $p$-waarde. 
Aangezien $\mathrm{U}_{2}$ absoluut gesproken, kleiner zal zijn dan $\mathrm{U}_{1}$, zal deze p-waarde kleiner zijn dan .5. Uit de formule (7.5) wordt bovendien duidelijk dat bij het hanteren van een ander afkappunt van de test de maximaal halalbare opbrengst wordt gevonden bij dezelfde p-waarde echter zowel de hoogte van de driehoek alsmede de ligging van de hoekpunten van de driehoek variëren met het afkappunt. Dit is nader uitgewerkt in de navolgende benadering van Doubilet.

Doubilet (1983) heeft een model ontwikkeld dat in principe gebaseerd is op de verwachtingswaarden van de test. Deze verwachtingswaarde wordt afgezet tegen de verwachtingswaarden van het alternatief "niets doen" zoals bijvoorbeeld in figuur 7.2 is gebeurd. Indien een test meerdere afkappunten heeft, dan hoort bij ieder afkappunt een bepaalde lijn die de verwachtingswaarde voorstelt van de teststrategie bij dat specifieke afkappunt.

Het principe kan gelllustreerd worden met behulp van een eenvoudig cijfervoorbeeld.

Stel $U_{2}=-600$ en $U_{1}=1000$ en de sensitiviteit en specificiteit van de afkappunten a en $b$ en $c$ bedragen respectievelijk:

$\begin{array}{ccc}\text { afkappunt } & \text { Se } & \text { Sp } \\ \text { a } & .60 & .90 \\ \text { b } & .80 & .80 \\ \text { c } & .90 & .60\end{array}$

Met behulp van de formule (7.2) kunnen de verwachtingswaarden van de teststrategieèn bepaald worden, behorende bij de respectievelijke afkappunten. In onderstaande figuur zijn deze verwachtingswaarden weergegeven.

Figuur 7.7. Verwachtingswaarden teststrategie met drie afkappunten

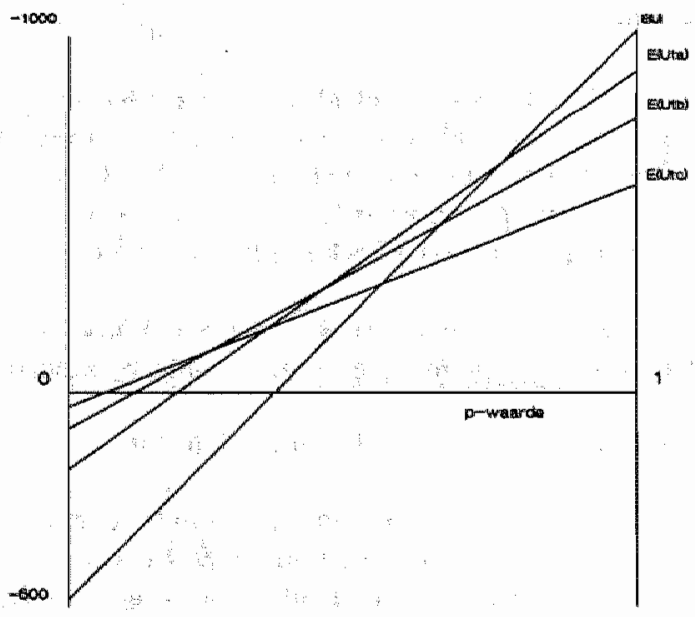

Uit de figuur valt voor iedere $\mathrm{p}$-waarde af te lezen, welk afkappunt de hoogste opbrengst vertegenwoordigt. Zijn er nog meer punten op de ROC-curve bekend, dam 
bestaat de omhullende lijn, welke de hoogste opbrengst aangeeft, uit meerdere lijnstukjes. Bij een continue test vertoont deze test een glooiend verloop (voor wiskundige afleiding zie Doubilet).

Wordt de incrementele opbrengst van een continue test weergegeven op de wijze zoals die hiervoor werd aangeduid, dan zien we dat deze niet langer weergegeven kan worden in de vorm van een driehoek. De incrementele opbrengst van een test neemt nu de gedaante aan. De volgende figuur geeft de meerwaarde weer van het hanteren van een afkappunt dat voor iedere a priori kans is geoptimaliseerd.

In onderstaande figuur 7.8 is dit weergegeven voor de ROC-curve die voldoet aan de specificatie $\mathrm{Se}=\left(1-\mathrm{Sp}^{2}\right)^{\text {th. }}$.

Figuur 7.8. Incrementele opbrengst van een continue test

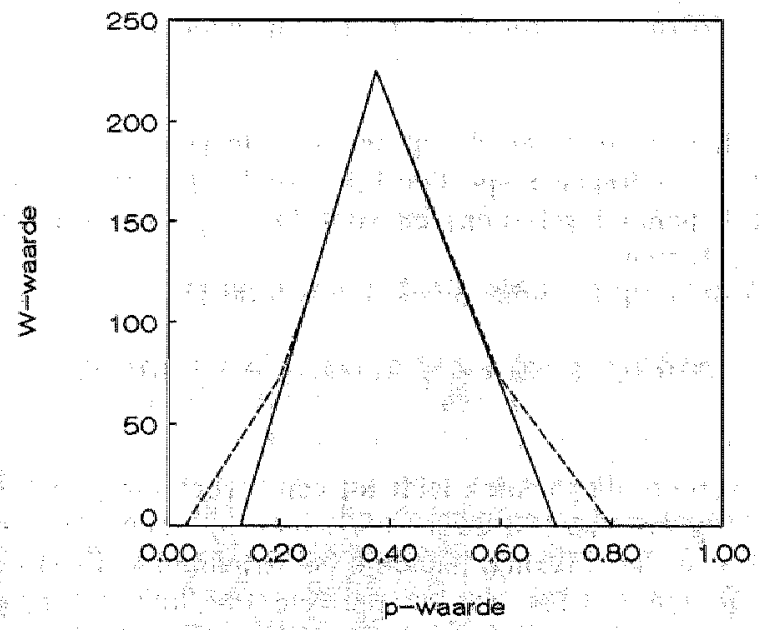

Een dergelijke figuur geeft aan hoeveel extra opbrengst kan worden gerealiseerd door het optimale afkappunt te kiezen afhankelijk van de a priori kans.

\subsection{TESTS IN DE GEZONDHEIDSZORG}

Hieronder wordt de bovenstaande methode toegepast op een voorbeeld uit de gezondheidszorg. Het voorbeeld heeft betrekking op het opsporen van patiènten met Left Main Disease (LMD) middels een inspannings-ECG. Bij deze test kan een drietal afkappunten worden gehanteerd waarbij de volgende sensitiviteit en specificiteit horen.

\section{Verdere gegevens:}

De a priori kans op de ziekte wordt voorlopig gesteld op .1. De kosten van de operatie bedragen $f 20.000,-$. De waarde van een QALY stellen we voorlopig op $f 100.000, \cdots$. De opbrengst in termen van gezondheidswinst behorende bij de operatie van een patiënt met LMD bedraagt één QALY en het verlies aan kwaliteit bij een patiënt die ten 
Tabel 7.2, Sensitiviteit en specificiteit bij verschillende afkappunten inspannings-ECG

Afkappunt: aantal mm st depressie:

(a) (b) (c)

Sensfinliteit

$.50 \quad .71 \quad .93$

$.88 \quad .73 \quad .58$

(Bron: Epstein a. a 1979)

onrechte geopereerd zou worden bedraagt .01 QALY. Binnen de teststrategie is er de keuze uit drie mogelijke afkappunten. Verder is het mogelijk om in plaats van het inspannings-ECG "perfecte" informatie te kopen middels het verrichten van een angiogram.

De eerste stap is het bepalen van de opbrengsten in geld. De in geld gewaardeerde uitkomsten $\mathrm{U}_{1}$ en $\mathrm{U}_{2}$ bedragen respectievelijk voor $\mathrm{U}_{1} f 80,000$,- (de waarde van een QALY minus de behandelingskosten) en voor $\mathrm{U}_{2}(-f 21.000,-)(-.01 \times f 100.000$,minus behandelingskosten).

De te verwachten opbrengst zonder uitwoering van de test voor $p=.1$ is:

$$
\mathrm{E}(\mathrm{U})=.10 \times f 80.000,-+.90 \times(-f 21.000,-)=-f 10.900,-
$$

Opereren zonder verdere diagnostiek leidt tot een verlies van $f 10.900,-$ De volgende vraag is of uitvoering van een test de te verwachten opbrengst kan verhogen. Hiertoe staan ons twee tests ter beschikking, namelijk het inspannings-ECG en het angiogram. Allereerst zal nagegaan worden wat de perfecte test qua opbrengst oplevert. Het angiogram beschouwen we als de gouden standaard, een test met een sensitiviteit en specificiteit van 1. De opbrengst wordt dan:

$$
\mathrm{E}\left(\mathrm{U}_{\mathrm{p}}\right)=.10 \times f 80.000,-=\text { f } 8.000,-
$$

Tenslotte kan de opbrengst van de teststrategie bepaald worden. Er zijn in principe drie verschillende afkappunten in dit voorbeeld. In de onderstaande figuur is de test afgebeeld met een sensitiviteit en specificiteit van respectievelijk .50 en .88 . De gegevens zijn berekend met behulp van de formules (7.7) $\mathrm{t} / \mathrm{m}$ (7.10). 
Figuur 7.9. Incrementele opbrengst inspannings-BCG $(W(T))$ en angiogram (W(P))

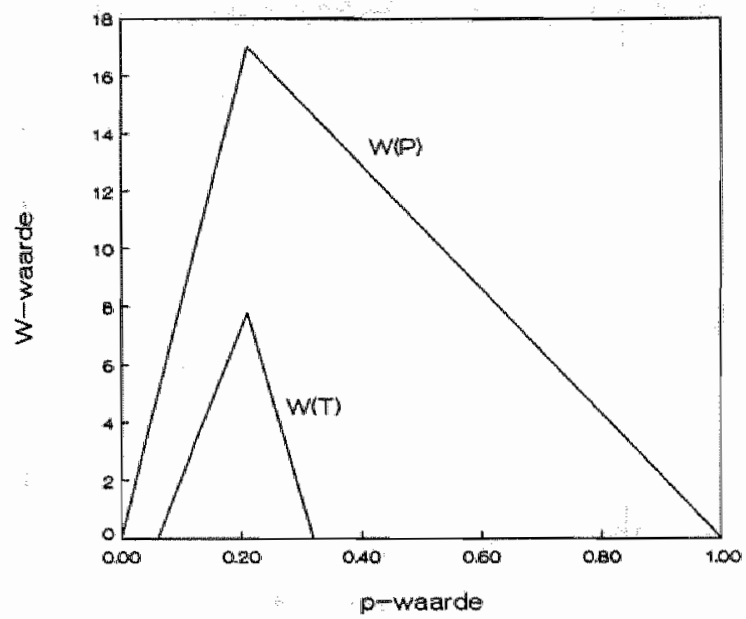

De maximale opbrengst van beide tests wordt bereikt voor een waarde voor $p$ van 21 . Voor waarden van $\mathrm{p}$, kleiner dan ,06 of groter dan 31 heeft het inspannings-ECG geen positieve waarde en komt eventueel alleen het angiogram in aanmerking. Uit de figuur blijkt dat bij een p van .10 de incrementele opbrengst van de ECG-test $f 1.732$,- is, waarbij dan overigens nog geen rekening is gehouden met de kosten van de test.

De volgende figuur laat de lijn zien die de punten verbindt waar, bij de gegeven sensitiviteit en specificiteit, de opbrengsten met de test even groot zullen zijn als zonder de test, met andere woorden waar de $W(T)=0$ (zie figuur 7.10). Het gebied boven de lijn geeft de combinaties van sensitiviteit en specificiteit weer waar de marginale waarde van de test positief is. Test c, met de hoogste sensitiviteit ligt beneden de nullijn, en is derhalve een test die bij de gegeven waarden van $p$ en $U_{1}$ en $U_{2}$ niet in aanmerking komt. De test behorende bij a ligt het verst verwijderd van de nullijn en is de beste test in deze situatie. 
Figuur 7.10. Incrementele waarden van inspannings-ECG (drie afkappunten)

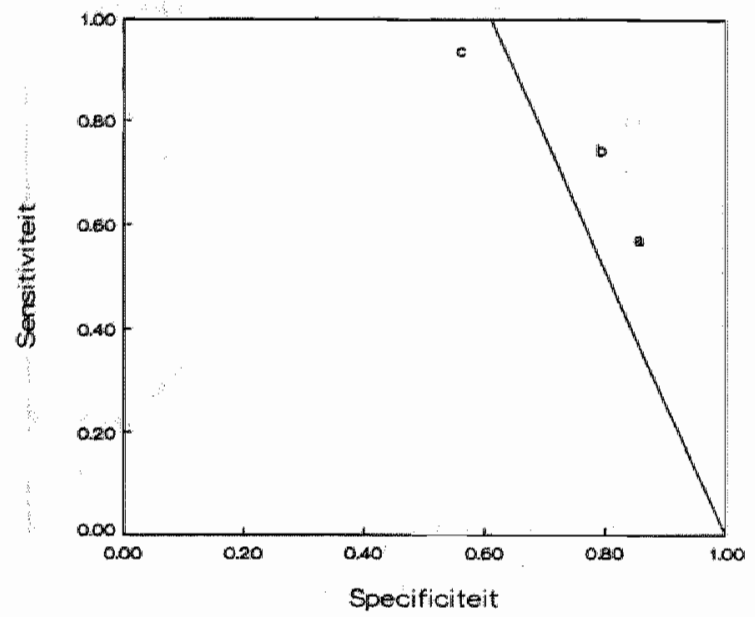

De opbrengsten van de test, behorende bij de afkappunten a en b bedragen respectievelijk $f 1.732$,- en $f 577,-$ Gezien de kosten van het inspannings-ECG (circa $f(300,-)$ komen beide tests in aanmerking. Bij een a priori kans van . 1 is het dus beter om een afkappunt te hanteren met een lagere sensitiviteit en een hogere specificiteit ook al houdt dat in dat de helft van de personen met de ziekte niet wordt opgespoord.

In de berekeningen is tot nu toe de waarde van een QALY $(M)$ gelijk gesteld aan een bepaald bedrag: $f 100.000,-$ Op basis van de bekende formules voor $E(U), E\left(U_{j}\right)$ en $E\left(U_{p}\right)$ kunnen vergelijkingen worden opgesteld waarmee de invloed van de hoogte van deze factor nader kan worden onderzocht. Als voorbeeld wordt weer afkappunt a genomen, waarbij de sensitiviteit .50 en de specificiteit .88 bedraagt.

Deze vergelijkingen zien er als volgt uit, waarbij er voorlopig vanuit wordt gegaan dat de a priori kans .1 bedraagt.

$$
\begin{aligned}
& \mathrm{E}(U)=.091 \mathrm{M}-f 20.000,- \\
& \mathrm{E}\left(U_{)}\right)=.0489 \mathrm{M}-f 3.160,- \\
& \mathrm{E}\left(\mathrm{U}_{p}\right)=.1 \mathrm{M}-f 2.000,-
\end{aligned}
$$

Duidelijk wordt dat de waarde van de test in sterke mate afhangt van de waarde van M. Bij de gegeven sensitiviteit en specificiteit en $\mathrm{p}$ zal de M-waarde groter moeten zijn dan $f 65,000$,- voordat de teststrategie een positieve verwachtingswaarde heeft. Voor de perfecte test wordt dit al bereikt bij de waarde van $f 20.000,-$, bij welke waarde de operatiekosten worden terugwerdiend door de te behalen gezondheidswinst.

Voor hoge waarden van $\mathrm{M}(\mathrm{M}>f 400.000,-)$ wordt het in het gegeven voorbeeld zelfs aantrekkelijk op grond van de verwachtingswaarden te besluiten niet te testen maar onmiddellijk te behandelen.

In de volgende figuur is een tweeweg-gevoeligheidsanalyse uitgevoerd met betrekking tot de factoren $\mathrm{M}$ en $\mathrm{p}$. 
Figur 7.11. Tweeweg-gevoeligheidsanalyse met betrekking tot $\mathrm{M}$ en $\mathrm{p}$

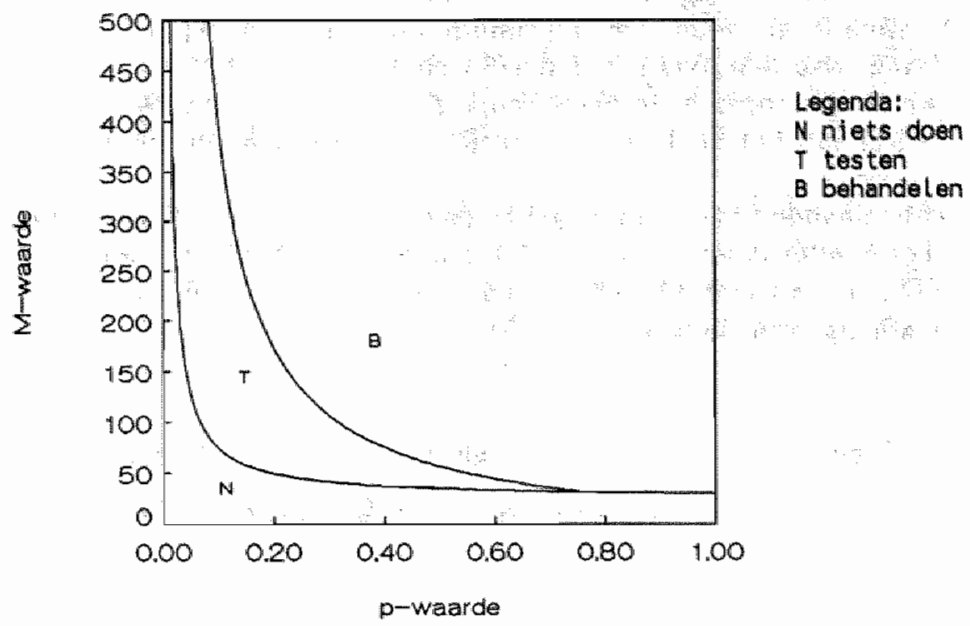

Het gebied $T$ bevat de combinaties van factoren $M$ en $p$ welke resulteren in een positieve incrementele opbrengst van de teststrategie. Links van het gearceerde gebied bevinden zich de combinaties, waarbij niets doen tot de hoogste opbrengst leidt; rechts van dit gebied heeft onmiddellijk ingrijpen de hoogste opbrengst. Bij hoge waarden van $M$ is het testgebied klein. Bij lage waarden groot.

\subsection{KOSTEN EN OPBRENGSTEN}

In de volgende stap worden ook de testkosten in de beschouwing betrokken.

Eerst gaan we terug naar figuur 7.8 waar de incrementele opbrengst is weergegeven voor de test en de perfecte test. Over het algemeen zal men kosten moeten maken om over de informatie van de test te kunnen beschikken, met andere woorden tegenover de opbrengsten staan kosten. In dit voorbeeld wordt uitgegaan van de volgende kosten: $f$ 3.000,- voor het angiogram en $f 300$,- voor het inspannings-ECG.

In een kosten-batenbenadering wordt gekeken naar het nettoverschil tussen opbrengsten en kosten. Grafisch kan dit op eenvoudige wijze worden geillustreerd door de opbrengst van de test met een constant bedrag (testkosten) te verminderen. Uit deze nettobenadering blijkt dat het angiogram bij alle p-waarden de voorkeur verdient boven het inspannings-ECG. Tevens blijkt dat er tengevolge van de kosten nu een gebied, gekenmerkt door lage p-waarden, ontstaat, waar het angiogram een negatieve nettoopbrengst laat zien en "niets doen" dus de voorkeur verdient boven uitwoeren van het angiogram. Aan de andere kant ontstaat er een gebied gekenmerkt door hoge pwaarden waar eveneens thet uitvoeren van een angiogram een negatieve opbrengst vertoont. In dat gebied zou het angiogram achterwege moeten blijven en zou onmiddellijk tot behandelen overgegaan moeten worden op grond van kostenbatenoverwegingen. 
Uit deze nettoberekening blijkt dat voor iedere waarde van p geldt dat het angiogram cen hogere waarde oplevert dan het inspannings- $E C G$, waarbij de kanttekening gemaakt moet wordlen, dat uitgegaan is van een $M$-waarde van $f 100.000^{-}$. Bij $M=f 30.000$,is de situatie als volgt. Het maximum van $W(T)$ en $W(P)$ ligt bij $p_{\mathrm{m}}=.67$ met de maximum waarden $\mathrm{W}(\mathrm{P})=f 6.678$, - en $\mathrm{W}(\mathrm{T})=f 3.359_{3}$-.

De netto-opbrengst is respectievelijk $f 3.678^{\text {,- }}$ en $f 3.059$, ,. Het verschil tussen de opbrengst van het angiogram en inspannings-ECG is nu dus relatief gering.

In onderstaande figuur zijn de gebieden aangegeven waar de respectievelijke strategieën het beste alternatief vormen. Met name het gebied van waarde van QALY's van $f 20.000$, - tot en met $f 30.000$,- is nader onderzocht, omdat hier de optimale strategie sterk afhangt van de waarde van $M$.

Figuur 7.12. Optimale strategie naar $\mathrm{M}$ en $\mathrm{p}$ (criterium $\mathrm{O}-\mathrm{K}$ )

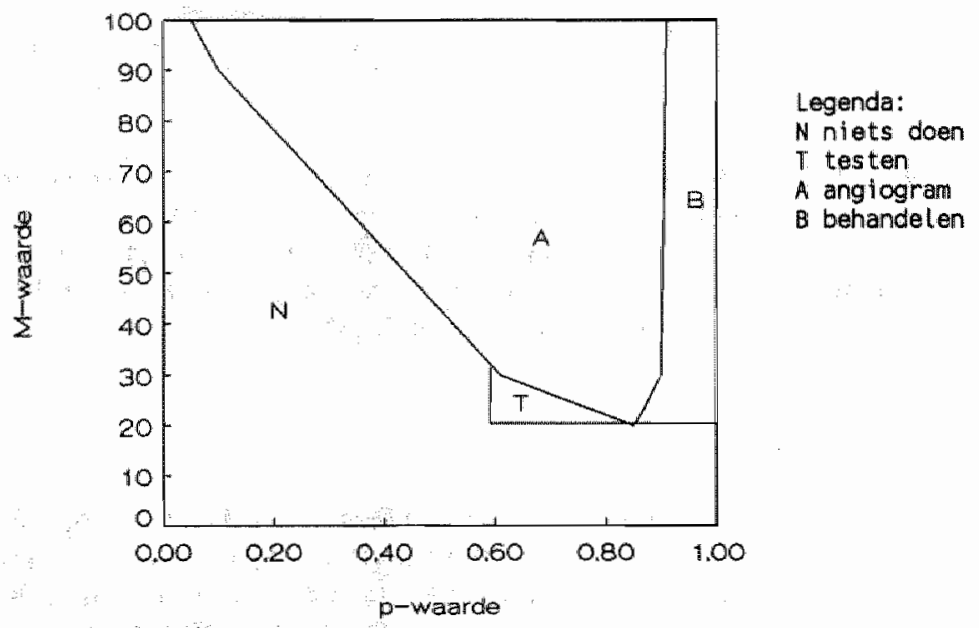

Het inspannings-ECG blijkt optimaal in een zeer beperkt gebied van de a priori kans en dan ook nog voor een bepaald waardenbereik van $M$ ( $M$ tussen $f 23.000$,- en $f 26.000,-)$. Het gebied waar het angiogram optimaal is, is bij deze waarde van $M$ iets groter, maar toch ook nog erg beperkt ten opzichte van het gebied waar "niets doen" de voorkeur verdient. Wordt de waarde van een QALY gesteld op minder dan f23.000,dan is de strategie "niets doen" de beste volgens het criterium $\mathrm{O}-\mathrm{K}$.

Overigens kan bij de beoordeling van de efficiency ook uitgegaan worden van de verhouding tussen opbrengsten en kosten (zie voorgaand hoofdstuk). 
Figuur 7.13. $\mathrm{O} / \mathrm{K}$ van het inspannings-ECG $(\mathrm{T})$ en het angiogram (A)

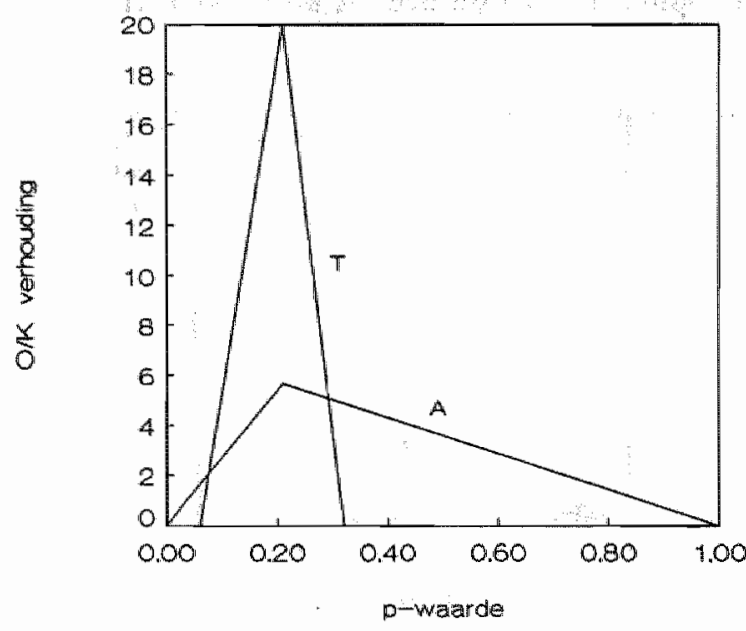

In de figuur zijn de opbrengsten (in geld) gewaardeerd $(M=f 100.000,-$. Hierdoor kan in deze benadering, in tegenstelling tot de $\mathrm{K} / \mathrm{O}$ berekening in voorgaande hoofdstukken, de in geld gewaardeerde opbrengst gedeeld wordt door de kosten. De $O / K$ is in deze benadering een verhoudingsgetal. Hoe hoger de $O / K$ verhouding, hoe beter het desbetreffende alternatief is. Voor $\mathrm{O} / \mathrm{K}$ verhoudingen kleiner dan een, wordt "niets doen" het te prefereren alternatief, of "onmiddellijk behandelen":

Uit deze figuur blijkt dat in het waardenbereik $(.07<p<.29)$ de ECG-test de hoogste $\mathrm{O} / \mathrm{K}$ ratio heeft en dus te prefereren is. Verder zijn er twee gebieden, grenzend aan dit gebied waar het angiogram de hoogste $0 / \mathrm{K}$ ratio laat zien $(.04<\mathrm{p}<.07)$ en $(.29<$ $\mathrm{p}<.86$ ). In de gebieden die hierbuiten liggen $\mathrm{p}<.04$ of $\mathrm{p}<.86$ geldt een $\mathrm{O} / \mathrm{K}$ ratio kleiner dan één en zou derhalve geen enkele test in aanmerking komen. In het eerste gebied geldt dat het zeer onwaarschijnlijk is dat de patiënt iets mankeert ( $\mathrm{p}$ is circa nul) en hier heeft "niets doen" de voorkeur. In een situatie waar het bijna zeker is dat de patiënt inderdaad ziek is, heeft "onmiddellijk behandelen" zonder diagnostische tests de voorkeur.

In figuur 7.13 is nog de vooronderstelling gemaakt dat de willingness-to-pay voor een naar kwaliteit gecorrigeerd levensjaar gelijk is aan $f 100.000,-$. In onderstaande analyse wordt ook deze veronderstelling losgelaten en wordt nagegaan hoe de strategieen veranderen onder invloed van de waarde van $M$. 
Figuur 7.14. Optimale strategie neer $\mathrm{M}$ en $\mathrm{p}$ (K/O-criterium)

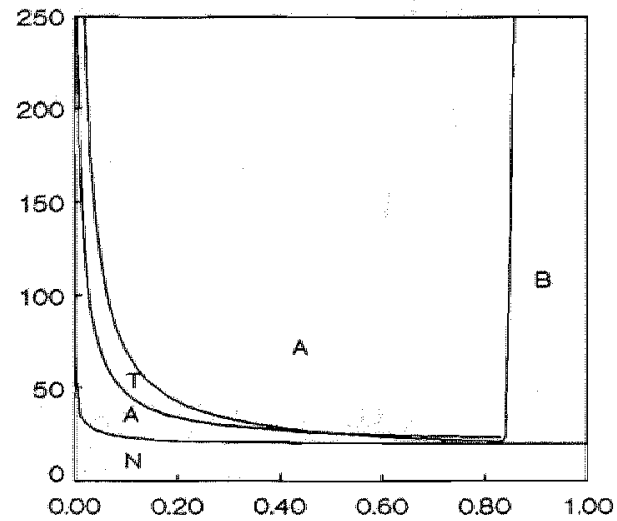

Legenda:

$N$ niets doen

$T$ testen

A angiogram

B behandelen

In figurur 7.14 bevat het resultaat van de analyse tot een bovengrens van $f 500.000$, voor een QALY, naar ons idee toch wel een uiterste bovengrens van wat maatschappelijk haalbaar lijkt, zeker als we dit vergelijken met andere gezondheidszorgprogramma's waarvoor dergelijke berekeningen zijn uitgevoerd. Overigens is het gemakkelijk in te zien hoe de grafiek verloopt buiten het hier weergegeven gebied. Naarmate men bereid is meer te betalen voor een QALY wordt het verrichten van duurdere diagnostiek zinvoller, voor jedere waarde van $p$ tussen .1 en .9. Met name bij lage waarden van $M$ (tot circa 100.000) zijn er voor verschillende waarden van $M$ verschillende optimale diagnostische strategieen. Wanneer $M$ nadert tot nul wordt de eventueel te behalen opbrengst zo gering dat de kosten niet opwegen tegen deze opbrengst en wordt het alternatief "niets doen" optimaal.

De belangrijkste conclusie uit bovenstaande analyse is dat het noodzakelijk is te weten wat de maatschappelijke bereidheid is om te betalen voor "naar kwaliteit gecorrigeerde levensjaren", om de optimale diagnostische strategie te kunnen bepalen in een willekeurige testsituatie. 


\section{OPTIMALE STRATEGIE BIJ TWEE TESTS}

\subsection{INLEIDING}

In het voorgaande hoofdstuk is een evaluatiemodel beschreven met behulp waarvan in een eenvoudige testsituatie de optimale strategie kan worden bepaald; waarbilj de strategieën betrekking hebben op respectievelijk: (1) niets doen, (2) test aanvragen of (3) onmiddellijk overgaan tot behandelen. Dit model kan toegepast worden indien er sprake is van een dichotome test (de vitslag van de test kan zijn: "positief" of "negatief") en indien de ziekte wordt gekenmerkt door een dichotomie (ziekte aanwezig of afwezig). Er is ook al op gewezen dat het vaak mogelijk is om verschillende afkappunten te hanteren bij een test, hetgeen de vraag oproept wellk afkappunt het beste is. In hoofdstuk 6 is hiervoor een oplossing aangedragen, waarbij de a priori kans (p) en de verhouding tussen positieve en negatieve effecten $\left(\mathrm{U}_{1} / \mathrm{U}_{2}\right)$ een belangrijke rol spelen. In dit hoofdstuk wordt het model verder uitgebreid. Het probleem waarvoor in dit hoofdstuk een oplossing wordt gezocht, is de situatie waarbij er sprake is van twee onafhankelijke tests, welke apart, in serie of parallel kunnen worden toegepast en waarbij elke test meerdere afkappunten kan hebben.

In hoofdstuk 5 is, in het voorbeeld geènt op Galen \& Gambino, ervan uitgegaan dat er bij combinatie van twee tests vijf mogelijke strategieèn zijn. Er is aldaar gewezen op de mogelijkheid om in een dergelijke situatie acht strategieèn te onderscheiden. Deze acht strategieen ontstaan indien zowel bij de serie- als parallellcombinatie een conjunctief (de combinatie wordt als positief beschouwd indien beide testuitslagen positief zijn) als ook een disjunctief positiviteitscriterium (slechts eén van beide tests behoeft positief te zijn) wordt gehanteerd. Om het positiviteitscriterium te omschrijven worden ook wel de volgende begrippen gehanteerd: "Believe the Positive Rule" voor disjunctief; "Believe the Negative Rule" voor conjunctief (Politser, 1982).

Ten opzichte van de vijf vermelde strategieën ontstaan twee extra seriecombinaties en een extra parallelcombinatie. Het totaal aantal mogelijke strategieën komt daarmee op tien, aangezien "niets doen" en "onmiddellijk behandelen" ook als strategie kunnen worden beschouwd.

Hebben beide tests echter meerdere afkappunten, dan neemt het aantal mogelijke teststrategieèn snel toe.

Stel bijwoorbeeld dat de eerste test $\mathrm{m}$ en de tweede test $\mathfrak{n}$ afkappunten kent. Het alleen toepassen van de eerste test kan op $\mathrm{m}$ verschillende manieren (afkappunten) geschieden en de tweede test kan op $\mathbf{n}$ verschillende wijzen worden toegepast. Er zijn verder vier combinaties mogelijk om tests in serie te combineren (twee verschillende volgorden en twee mogelijke positiviteitscriteria) en er zijn twee manieren om tests parallel te combineren (twee positiviteitscriteria). In totaal levert dit $(6 * \mathrm{~m} * \mathrm{n})$ combinaties op. Indien ook de strategieën "niets doen" en "onmiddellijk behandelen" worden meegerekend, dan is het aantal mogelijke strategieën (a) met behulp van de volgende formule te berekenen:

$$
a=m+n+\left(6^{*} m * n\right)+2
$$


Bij respectievelijk 3 en 4 mogelijke afkappunten bedraagt het aantal strategieën 81 . Bij 6 en 7 afkappunten is het aantal strategieetn al opgelopen tot 267.

Het hier gepresenteerde model is een verdere uitwerking van het werk van onder andere Eeckhoudt e.a. (1984) en Doubilet (1983), die zich bezig hebben gehouden met de bepaling van het optimale afkappunt bij een test, en het werk van Hershey e.a. (1986) die de optimaliseringproblematiek bij twee dichotome tests bestudeerden. Overigens is dit laatste werk een voortzetting wan eerder gepubliceerd werk (Cebul e.a., 1982). In dit eerdere werk is de waarde wan tests en testcombinaties bepaald met behulp van het predictieve waarde-model, dus los van eventueel te behalen therapeutische winst. In Hershey e.a. (1986) wordt hiermee wel rekening gehouden. Het onderhavige werk is echter een uitbreiding in die zin dat ook de kosten van de teststrategieen expliciet worden meegenomen bij het bepallen van de optimale strategie. Het bepalen van de optimale strategie kan gebaseerd worden op het criterium O-K dan wel het criterium K/O. Met het ontwikkelde model kan nagegaan worden in hoeverre de optimale teststrategie afhangt van het te hanteren optimaliseringscriterium.

Verder kan met dit model een zogenaamde marginale analyse worden uitgevoerd, hetgeen inhoudt dat bij een serietest nagegaan kan worden wat de kosten en opbrengsten zijn van de tweede test. Tenslotte wordt in de optimaliseringsprocedure rekening gehouden met de optimale afkappunten van de eerste en de eventuele vervolgtest.

In paragraaf 8.2 zullen eerst de problemen worden besproken welke samenhangen met het combineren van tests. Daarbij wordt nagegaan wat de sensitiviteit en specificiteit is van de diverse serie- en parallelcombinaties, rekening houdend met het positiviteitscriterium. In par. 8.3 wordt nader ingegaan op de economische evaluatie-aspecten van het onderhavige probleem. Doordat in het model de kosten van tests expliciet in de beschouwing worden betrokken dienen er afspraken gemaakt te worden over de wijze waarop de economische evaluatie gestalte krijgt. In par. 8.4 wordt een voorbeeld uit de literatuur besproken waarop het rekenmodel wordt toegepast. In deze paragraaf worden de invoergegevens besproken. In de volgende paragraaf (8.5) worden de resultaten vermeld, verkregen op grond van deze gegevens; waarbij zowel geoptimaliseerd wordt volgens het $\mathrm{O}-\mathrm{K}$ als ook het $\mathrm{K} / \mathrm{O}$ criterium. In de daaropvolgende paragraaf 8.6 wordt met behulp van gevoeligheidsanalyses de robuustheid van de verkregen resultaten bestudeerd. Hoe sterk veranderen de oplossingen indien de aanvankelijke schattingen variëren. In 8.7 tenslotte wordt nader ingegaan op de (economische) betekenis van de analyse en worden de mogelijkheden en beperkingen aangegeven. Daarbij zal met name aandacht besteed worden aan de efficiency-verbetering, welke behaald kan worden, indien protocollen gehanteerd worden, gebaseerd op de modeluitkomsten.

\subsection{COMBINATIE VAN TWEE TESTS}

Indien twee dichotome tests in combinatie met elkaar worden toegepast, zijn er in principe vier mogelijkheden. In onderstaand overzicht zijn deze mogelijkheden weergegeven. 
Test 2

positief negatief

test 1

positief I II

negatief III IV

Nu kan de combinatie van lests als positief beschouwd worden indien beide tests positief zijn. Alleen de uitslag in veld I wordt dan als positief beschouwd. Wordt echter de testcombinatie alls positief beschouwd indien minimaal een van de tests positief is, dan zijn de uitslagen in veld I, II en III positief. Het eerste wordt een conjunctief positiviteitscriterium genoemd, het tweede is een disjunctief positiviteitscriterium. Indien dit onderscheid gehanteerd wordt, ontstaan zowel binnen de serie- als binnen de parallelcombinatie extra mogelijkheden.

Het totaal aantal teststrategieèn bedraagt dan 8 , te weten:

strategie 1) test 1

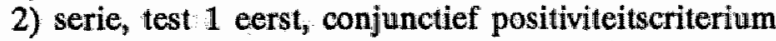

3) serie, test 1 eerst, disjunctief positiviteitscriterium

4) test 2

5) serie, test 2 eerst, conjunctief positiviteitscriterium

6) serie, test 2 eerst, disjunctief positiviteitscriterium

7) parallel, conjunctief positiviteitscriterium

8) parallel, disjunctief positiviteitscriterium

Daarnaast zijn er nog twee strategieën:

9) niets doen

10) onmiddellijk behandelen

Bij een conjunctief criterium wordt in geval wan serietests de tweede test uitgevoerd indien de eerste positief is en bij een disjunctief criterium indien de eerste negatief is. Dit biedt de mogelijkheid om de hiervoor genoemde seriestrategieen te beschrijven in de worm van een protocol:

Strategie 2* eerst test 1 , indien positief dan test 2

Strategie 3: eerst test 1, indien negatief dan test 2

Strategie 5; eerst test 2, indien positief dan test 1

Strategie 6: eerst test 2 , indien negatief dan test 1

Duidelijk zal zijn dat de sensitiviteit en de specificiteit van de testcombinaties onder andere bepaald worden door het positiviteitscriterium.

De groep zieken $(D+)$ kan na toepassing van twee tests verdeeld worden in vier subgroepen, al naar gelang de zieken opgespoord worden door een of twee tests. 
Schema 8.2. Sensitiviteit wan testcombinaties

Aantal opgespoorde zieken

Test 2

\begin{tabular}{llc}
\hline & $\mathrm{T}_{2}^{+}$ & $\mathrm{T}_{2}^{+}$ \\
\hline $\mathrm{T}_{1}^{*}$ & $\mathrm{Se}_{1} \cdot \mathrm{Se}_{2}$ & $\mathrm{Se}_{1}\left(1-\mathrm{Se}_{2}\right)$ \\
\hline $\mathrm{T}_{1}^{*}$ & $\left(1-\mathrm{Se}_{1}\right) \cdot \mathrm{Se}_{2}$ & $\left(1-\mathrm{Se}_{1}\right)\left(1-\mathrm{Se}_{2}\right)$ \\
\hline
\end{tabular}

De sensitiviteit van de testcombinatie is bij een conjunctief positiviteitscriterium: $\mathrm{Se}_{1}, \mathrm{Se}_{2}$

en bij cen disjunctief positiviteitscriterium:

$$
\mathrm{Se}_{1}+\mathrm{Se}_{2}-\left(\mathrm{Se}_{1} \cdot \mathrm{Se}_{2}\right)\left(=\mathrm{Se}_{1} \cdot \mathrm{Se}_{2}+\mathrm{Se}_{1}\left(1-\mathrm{Se}_{2}\right)+\left(1-\mathrm{Se}_{1}\right) \cdot \mathrm{Se}_{2}\right)
$$

Op dezelfde wijze kan de specificiteit van de testcombinaties bepaald worden uit de kenmerken van de afzonderlijke tests.

Schema 8.3. Sensitiviteit en specificiteit van combinaties van onafhankelijke tests

positiviteitscriterium

\begin{tabular}{lll}
\hline & conjunctief & disjunctief \\
\hline Sensitiviteit & $\mathrm{Se}_{1} \cdot \mathrm{Se}_{2}$ & $\mathrm{Se}_{1}+\mathrm{Se}_{2}-\mathrm{Se}_{1} \cdot \mathrm{Se}_{2}$ \\
Specificiteit & $\mathrm{Sp}_{1}+\mathrm{Sp}_{2}-\mathrm{Sp}_{1} \cdot \mathrm{Sp}$ & $\mathrm{Sp}_{1} \cdot \mathrm{Sp}_{2}$ \\
\hline
\end{tabular}

Dit leidt bij een conjunctief positiviteitscriterium tot een test met een relatief lage sensitiviteit en een relatief hoge specificiteit, terwijl omgekeerd bij een disjunctief positiviteitscriterium de specificiteit relatief laag is, in combinatie met een relatief hoge sensitiviteit.

Een volgende vraag is of de sensitiviteit en de specificiteit van de testcombinatie bij seriebenadering gelijk is aan sensitiviteit en specificiteit van de parallelbenadering? Stel we hanteren een conjunctief criterium. Bij de combinatie worden uitslagen dan positief genoemd indien de onderliggende tests beiden positief zijn. Bij de parallelcombinatie zijn de uitslagen gelijktijdig bekend. Bij de serietest ontstaat de mogelijkheidd om ná de 
eerste test te beslissen of de tweede test al dan niet moet worden uitgevoerd. Bij een conjunctief positiviteitscriterium geldt dat de tweede test uitgevoerd moet worden, indien de eerste test positief uitvalt. Bij een negatieve eerste testuitslag kan gestopt worden omdat niet meer aan het gestelde criterium voldaan kan worden. Uiteindelijk wordt in de serieteststrategie hetzelfde aantal positieve gevallen ontdekt als in de parallelstrategie, met andere woorden de sensitiviteit van beide strategieen is gelijk.

Bij de serietest wordt eenzelfde resultaat verkregen met inzet van minder diagnostische middelen. Bij de paralleltest komt de informatie sneller beschikbaar en deze tijdwinst moet vergeleken worden met de hogere kosten van de paralleltest.

Wordt een disjunctief criterium gehanteerd, dan kan dezelfde redenering worden gevolgd. De testcombinatie is positief indien én van beide tests positief is. Is de eerste positief, dan hoeft de tweede niet meer uitgevoerd te worden omdat altijd aan het criterium voldaan zal zijn. Voor de specificiteit van de testcombinaties kan dezelfde redenerimg opgezet worden, waaruit blijkt dat er ook op dit punt geen verschillen zijn tussen de parallelbenadering en de seriebenadering.

Samenvattend kan gesteld worden dat de sensitiviteit en specificiteit van een serivetest gelijk is aan de sensitiviteit en specificiteit van een parallelcombinatie indien eenzelfde positiviteitscriterium wordt gehanteerd. Deze min of meer voor de hand liggende conclusie wordt toch door veel auteurs niet getrokken. Zo geeft bijvoorbeeld Büttner (1982) de afzonderlijke formules van parallel-en serietests zonder de gelijkenis op te merken.

In het boek "Beyond Normality: The Predictive Value and Efficiency of Medical Diagnoses" (1975) gaan de auteurs Galen \& Gambino als volgt te werk. Zij hanteren voor de seriebenadering een conjunctief positiviteitscriterium, terwijl ze voor de parallelcombimatie een disjunctief criterium hanteren. Vervolgens concluderen ze (op pag. 42):

"Parallel testing results in the highest sensitivity but the lowest specificity, whereas series testing results in the lowest sensitivity but highest specificity".

In Bennington (1981) is deze conclusie uit zijn oorspronkelijk verband gerukt:

"For two tests run simultaneously but considered positive if either result is positive or negative if both results are negative, the sensitivity is greater and the specificity is lower than if the same tests were run in series and analysed sequentially".

Zoals boven uiteengezet worden de verschillen in sensitiviteit en specificiteit van de serie- en parallelbenadering louter en alleen veroorzaakt door het hanteren van een verschillend positiviteitscriterium.

Bij onafhankelijkheid wan tests kunnen de sensitiviteit en specificiteit van de combinaties rechtstreeks berekend worden uit de sensitiviteit en specificiteit van de afzonderlijke tests. Bij een conjunctief positiviteitscriterium is de sensitiviteit lager en de specificiteit hoger dan de afzonderlijke tests en het omgekeerde geldt bij een disjunctief positiviteitscriterium.

\subsection{ECONOMISCHE EVALUATIE VAN TESTCOMBINATIES}

\subsubsection{Inleiding}

In principe kunnen de twee combinaties van onafhankelijke tests, welke ontstaan bij het hanteren van de twee positiviteitscriteria beschouwd worden als extra tests welke 
getvalueerd kunnen worden met behulp van de methode beschreven in de voorgaande hoofdstukken. Hierbij doen zich echter enkele complicaties voor:

- Bij een serietest ontstaat tussentijds de mogelijkheid am te besluiten de tweede test all dan niet uit te woeren. Dit probleem wordt in de volgende paragraaf behandeld onder de incrementele analyse.

- Bij gebruik maken wan het $\mathrm{K} / \mathrm{O}$ criterium is het niet mogelijk de richtingscoefficienten van de raaklijn die het optimale afkappunt aanduidt rechtstreeks te bepalen.

Tot nu toe is uitgegaan van onafhankelijkheid van tests. Nagegaan zal worden op welke wijze de oplossing verandert, indien niet (of niet volledig) aan deze veronderstelling wordt voldaan.

In paragraaf 8.3.2 zal eerst nader ingegaan worden op de relatie tussen het te hanteren criterium (conjunctief of disjunctief) bij combinaties van twee tests en de a priori kans. In paragraaf 8.3.3 zal worden ingegaan op de incrementele analyse in samenhang met de te hanteren optimaliseringscriteria ( $\mathrm{K} / \mathrm{O}$ of $\mathrm{O}-\mathrm{K})$. In de daaropvolgende paragraaf 8.3.4 zal nader worden ingegaan op de problemen die ontstaan indien afhankelijke tests worden gecombineerd. Tevens zullen beslisregels worden geformuleerd, die gebruikt kunnen worden bij het maken van een keuze tussen een conjunctief- dan wel een disjunctief criterium.

\subsubsection{Conjunctief of disjunctief}

Bij een economische evaluatie moet een aantal beslissingen genomen worden over de wijze van evalueren zelf. In deze paragraaf zal een aantal van deze beslissingen geëxpliciteerd worden. Daarbij zullen we aansluiten bij het model van Hershey e.a. (1986), waarin die strategie wordt bepaald met de hoogste opbrengsten in termen van gezondheidswinst. Het expliciet betrekken van de kosten bij de optimalisatie brengt een aantal problemen met zich mee. Besloten moet worden of er geoptimaliseerd dient te worden met als criterium: opbrengsten min kosten ( $\mathrm{O}-\mathrm{K})$ dan wel: kosten/opbrengsten $(\mathrm{K} / \mathrm{O})$.

Bij het eerste criterium wordt die strategie gekozen welke het grootste verschil laat zien tussen opbrengsten en kosten, terwijl bij het tweede criterium dát alternatief de voorkeur geniet, waarbij een eenheid opbrengst tegen de geringste kosten kan worden geproduceerd.

Bovendien blijkt in samenhang hiermee een ander probleem op te duiken. Dit betreft het reeds vermelde probleem van de incrementele analyse, een probleem dat zich enkel en alleen bij de serietest voordoet. Hieronder zal eerst ingegaan worden op de bepaling van de optimale strategie bij paralleltests.

Een paralleltest kan in principe beschouwd worden als een testprocedure waarvan de kosten eenvoudig te bepalen zijn en waarvan de opbrengsten eveneens eenvoudig zijn te bepalen. De sensitiviteit en specificiteit van deze combinatie zijn namelijk rechtstreeks te bepalen met behulp van voorgaande formules. Bij twee positiviteitscriteria zijn er dan twee testcombinaties. In de onderstaande tabel is een eenvoudig cijfervoorbeeld uitgewerkt. De gegevens, evenals de hierna volgende figuren zijn gebaseerd op gegevens uit tabel 8.2 . 
Tabel 8.1. Cijfervoorbeeld combinatie twee onafhankelijke tests

positiviteitscriterium

\begin{tabular}{|c|c|c|c|c|}
\hline & $\mathrm{T} 1$ & $\mathrm{~T} 2$ & Conjunctief & Disjunctief \\
\hline Sensitiviteit & .96 & .79 & .7584 & .9916 \\
\hline Specificiteit & .88 & .885 & .9862 & .7788 \\
\hline
\end{tabular}

Zijn verder de a priori kans en de opbrengsten bekend, dan kan met behulp van de isoquanten (zie vorig hoofdstuk) de optimale strategie bepaald worden. Hierbij dient overigens wel een verrekening voor de kostenverschillen van de vier (combinaties van) tests te worden toegepast.

Uit deze methode blijkt dat bij lage a priori kansen een conjunctief positiviteitscriterium wenselijk is. Bij hogere a priori kansen kan een disjunctief criterium de voorkeur verdienen.

Indien de oorspronkelijke tests gekenmerkt worden door meerdere mogelijke afkappunten, dient deze procedure een aantal malen herhaald te worden voor het bepalen van de optimale strategie.

Met behulp van de formules uit schema 8.3 kunnen de sensitiviteit en specificiteit van alle disjunctieve en conjunctieve combinaties worden berekend. Bij combinatie van een bepaald afkappunt van de ene test met alle afkappunten van de andere test blijken zowel de disjunctieve als conjunctieve combinaties zelf weer een "soort" ROC-curve te vormen. Deze ROC-curves zijn te beschouwen als projecties van de oorspronkelijke ROC-curve. Hieronder zullen deze nieuwe ROC-curves aangeduid worden met de term "geprojecteerde" ROC-curves. In de volgende figuur is de ligging van een conjunctieve en disjunctieve "geprojecteerde" ROC-curve weergegeven ten opzichte van de oorspronkelijke ROC-curves. 
Figuur 8.1. ROC-curves plus "geprojecteerde" conjunctieve en disjunctieve ROC-curves

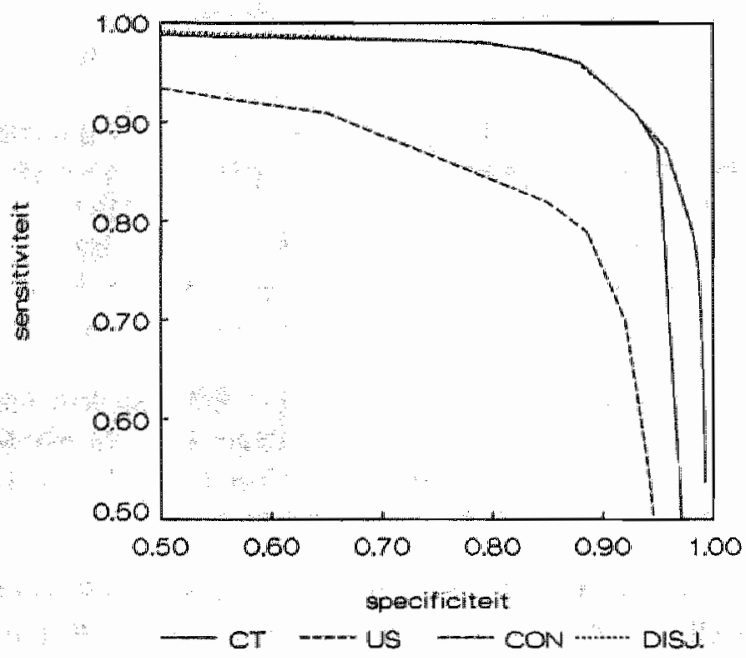

De figuur onderstreept nog eens duidelijk bovenstaande conclusies met betrekking tot de verbanden tussen a priori kans en het hanteren van het positiviteitscriterium. Bij lage a priori kansen zullen de isoquanten vrijwel evenwijdig lopen met de sensitiviteitas. De conjunctieve combinaties zullen dan een hogere opbrengst vertegenwoordigen. Bij het combineren van tests is niet sprake van éen projectie, maar van evenveel projecties als er afkappunten zijn gebruikt in de eerste test. In onderstaande figuren zijn deze geprojecteerde ROC-curves weergegeven voor alle conjunctieve en alle disjunctieve combinaties.

Figuren $8.2 \mathrm{a}$ en $8.2 \mathrm{~b}$ Conjunctieve en disjunctieve geprojecteerde ROC-curves.
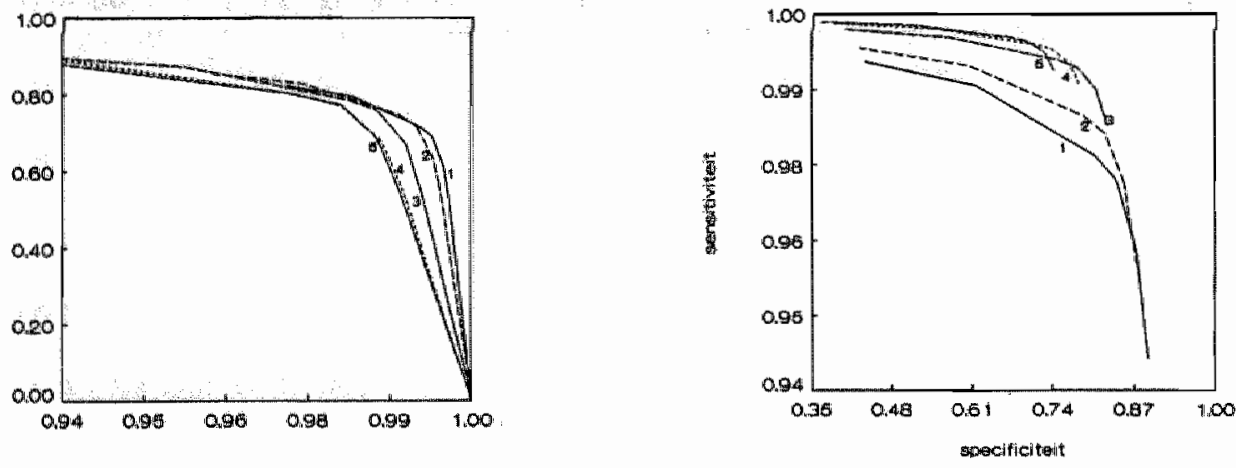

Uit de figuur blijkt dat deze geprojecteerde ROC-curves elkaar kunnen snijden. Dit betekent dat naarmate de a priori kans verandert, wisselende combinaties van afkappunten van beide tests tot optimale opbrengsten leiden. Bij hantering van het $\mathrm{K} / \mathrm{O}$ 
criterium is de bepaling van de optimale strategie complexer, zoals uit hoofdstuk 6 reeds bleek. Bovenstaande conclusies blijven echter geldig.

\subsubsection{Incrementele analyse}

Bij de seriebenadering ontstaat er een extra beslismoment ná de eerste test. De incrementele analyse schrijft voor, dat op ieder beslismoment een evaluatie dient plaats te vinden van extra kosten en extra opbrengsten welke door de betreffende beslissing teweeg worden gebracht.

Bij een serietest dienen dus de incrementele kosten en opbrengsten behorende bij de tweede test apart te worden vastgesteld. Veronachtzaming wan dit principe kan leiden tot een grote mate van inefficiency.

Een klassiek voorbeeld van een dergelijke dure vorm van het produceren van gezondheid betreft de invoering van een testprocedure voor de opsporing van colonkanker (Neuhauser \& Levicki, 1975). In dit protocol is sprake van een herhaling van de test, tot zes keer toe, om geen enkel geval van colonkanker te missen. De auteurs berekenen de extra kosten en de extra opbrengsten bij iedere van de zes herhaaltests. Na iedere stap is de verhouding tussen kosten en opbrengsten ongunstiger, wooral doordat de extra opbrengsten steeds verder afnemen. Uitvoering van de zesde herhaaltest zou impliceren dat een bedrag van $\$ 47$ miljoen nodig is voor het opsporen van een extra geval van colonkanker.

Bij hantering van het $\mathrm{O}-\mathrm{K}$ criterium is het zo dat indien een seriestrategie als beste strategie aangemerkt wordt, de tweede test uitgevoerd moet worden. Indien de betreffende seriestrategie de hoogste netto opbrengsten vertoont van alle strategieen, kan men er zeker van zijn dat de tweede test, op zichzelf beschouwd, ook hogere opbrengsten dan kosten heeft. Als dit niet het geval zou zijn, dan zou het alleen uitvoeren van de eerste test de strategie met de hoogste O-K zijn.

Bij de $\mathbb{K} / \mathrm{O}$ benadering werkt de incrementele analyse als volgt. Indien de $\mathrm{K} / \mathrm{O}$ verhouding van de seriestrategie kleiner is dan de $K / O$ verhouding van de eerste test, dient de tweede test uitgevoerd te worden.

Indien de $\mathrm{K} / \mathrm{O}$ verhouding van de serietest groter is dan de $\mathrm{K} / \mathrm{O}$ van de eerste test, kan met zich afvragen of de tweede test uitgevoerd dient te worden of niet. Uitvoering zorgt ervoor dat de $\mathrm{K} / \mathrm{O}$ verhouding van de totale procedure stijgt, maar zolang de $\mathrm{K} / \mathrm{O}$ verhouding nog beneden de maximumwaarde van een QALY ligt, is er geen sprake van inefficiency in dit opzicht. Van ineffiency is sprake indien de $\mathrm{K} / \mathrm{O}$ verhouding van de tweede test groter is dan deze maximumwaarde.

In hoofdstuk 6 is reeds ingegaan op de theoretische verschillen tussen O-K Ook bleek dat er verschillende oplossingen verkregen worden bij verschillende benaderingen.

Dit en het feit dat niet van tevoren vast staat welke van beide benaderingen als de meest wenselijke kan worden beschouwd, heeft ertoe geleid om in het rekenprogramma beide optimaliseringsmogelijkheden in te bowwen. $\mathrm{Bij}$ de $\mathrm{K} / \mathrm{O}$ optimalisering is rekening gehouden met incrementele analyse van de tweede test. 


\subsubsection{Combinatle van (on)afhankelijke tests}

Hieronder zall nader worden ingegaan op de veranderingen in de sensitiviteit en specificiteit van combinatie van tests, welke in meer of mindere mate afhankelijk zijn van elkaar.

Bij volledige onafhankelijkheid geldt, bij een conjunctief positiviteitscriterium:

$$
P\left(T_{1}+n T_{2}+\right)=P\left(T_{1}+\right) \cdot P\left(T_{2}+\right)
$$

en bij een disjunctief positiviteitscriterium:

$$
\mathrm{P}\left(\mathrm{T}_{1}+\mathrm{U} \mathrm{T}_{2}+\right)=1-\mathrm{P}\left(\mathrm{T}_{1}-\right) \cdot \mathrm{P}\left(\mathrm{T}_{2}-\right)
$$

waarbij $\mathrm{p}\left(\mathrm{T}_{1}+\right)$ de kans is op een positieve uitslag etc.

De sensitiviteit en specificiteit van combinaties van onafhankelijke tests zijn rechtstreeks uit de reeds bekende parameters van de afzonderlijke tests te berekenen (zie schema 8.2 voor de formules).

Voor de sensitiviteit kan de volgende redenering worden opgezet. Stel dat de situatie bij volledige onafhankelijkheid wordt voorgesteld door situatie $\mathrm{A}$, waarbij het gearceerde gebied aangeeft hoeveel patiënten er door beide tests opgespoord worden. Indien er sprake is van afhankelijkheid (en de tests zijn positief aan elkaar gecorreleerd) zal het overlappende gedeelte van de verzamelingen groter worden (zie het onderstaande venndiagram $B$ ).

Figuur 8.3. Verzameling aantal zieken
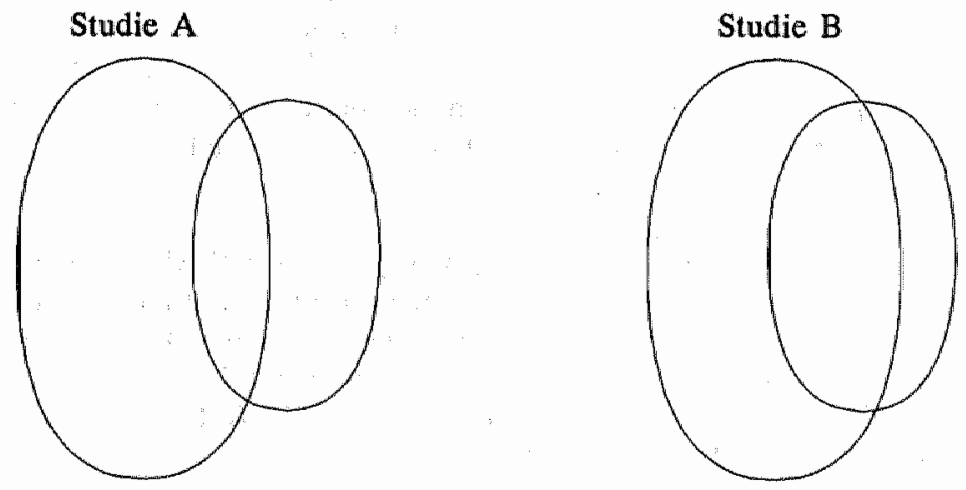

Te constateren valt dat, bij afhankelijkheid:

1. de sensitiviteit van de combinatie met een conjunctief positiviteitscriterium hoger is dan bij onafhankelijkheid,

2. de sensitiviteit van de combinatie met een disjunctief positiviteitscriterium lager is dan bij onafhankelijkheid. 
In onderstaande $2 \times 2$ tabellen staan met betrekking tot de zieken de uitersten weergegeven voor de tests met de in tabel 8.1 gegeven sensitiviteit; waarbij de cerste $2 \times 2$-tabel volledige onafhankelijkheid en de tweede $2 \times 2$-tabel volledig afhankelijkheid voorstelt.

volledig onafhankelijk

\begin{tabular}{|c|c|c|c|c|}
\hline & & + & - & \\
\hline \multirow{2}{*}{$\mathrm{T}_{1}$} & + & 758 & 202 & 960 \\
\hline & - & 32 & 8 & 40 \\
\hline & & 790 & 210 & 1000 \\
\hline
\end{tabular}

volledig afhankelijk

\begin{tabular}{|c|c|c|c|c|}
\hline & & + & - & \\
\hline \multirow{2}{*}{$\mathrm{T}_{1}$} & + & 790 & 170 & 960 \\
\hline & - & 0 & 40 & 40 \\
\hline & & 790 & 210 & 1000 \\
\hline
\end{tabular}

Er blijkt nu een eenwoudige relatie te bestaan tussen de beide uitersten, waarin de diverse stadia van (on)afhankelijkheid kunnen worden aangegeven. De randtotalen zijn namelijk een gegeven (op grond van de gegeven sensitiviteit). Laten we het aantall personen in gebied $\left(\mathrm{T}_{1}+\cap \mathrm{T}_{2}+\right)$ met cén toenemen, dan moet er een persoon uit een van de twee aangrenzende gebieden worden verwijderd. In het gegeven voorbeeld is 790 het maximaal aantal personen in het gebied $\left(\mathrm{T}_{1}{ }^{+} \cap \mathrm{T}_{2}{ }^{+}\right)$. Dit aantal wordt bepaald door de laagste sensitiviteit van de twee tests. Bevinden zich in het betreffende gebied bijvoorbeeld 760 personen dan is de totale verdeling van personen als volgt:

\begin{tabular}{ccc}
760 & 200 & 960 \\
30 & 10 & 40 \\
\hline 790 & 210 & 1000
\end{tabular}

Uit bovenstaande analyse blijkt dat naarmate de tests meer afhankelijkheid vertonen de sensitiviteit van de combinatie met een conjunctief positiviteitscriterium de sensitiviteit van de enkele test met de laagste sensitiviteit zal benaderen. De sensitiviteit van de combinatie van tests met een disjunctief positiviteitscriterium nadert, naarmate de afhankelijkheid toeneemt, de sensitiviteit van de enkele test met de hoogste sensitiviteit. De extra opbrengst van de tweede test zal geringer zijn naarmate de afhankelijkheid toeneemt.

Op identieke wijze kan worden bewezen dat bij een conjunctief positiviteitscriterium de specificiteit van de combinatie van volledig afhankelijke tests gelijk is aan de specificiteit van de enkele test met de laagste specificiteit.

Bij een disjunctief criterium is de specificiteit gelijk aan de specificiteit van de enkele test met de hoogste specificiteit. 
Indien in de praktijk 2 afhankelijke test met elkaar gecombineerd worden, kan de sensitiviteit en specificiteit van de combinaties alleen bepaald worden door empirisch ciffermateriaal. Is dit materiaal voorhanden, dan kan voor beide positiwiteitscriteria de sensitiviteit en specificiteit van de combinatie worden bepaald.

De ligging van beide combinaties kan worden voorspeld. Stel dat $T_{C}$ het punt is dat de combinatie voorstelt van twee onafhankelijke tests met een conjunctief criterium en $T_{D}$ idem met een disjunctief criterium.

De conjunctieve combinatie van afhankelijke tests zal liggen tussen $T_{C}$ en de meest specifieke van de twee tests. De disjunctieve combinatie zal liggen tussen $T_{D}$ en de meest sensitieve van de twee tests. Hoe groter de afhankelijkheid is des te kleiner wordt de afstand tot deze tests en des te geringer zal de extra waarde van de combinaties kunnen zijn ten opzichte van de enkele tests.

In onderstaande figuur zijn de potentiële liggingen wan de respectievelijke combinaties van afhankelijke tests weergegeven voor het bovenstaande rekenvoorbeeld.

Figuur 8.4. Se en $\mathrm{Sp}$ van combinaties van afhankelijke tests.

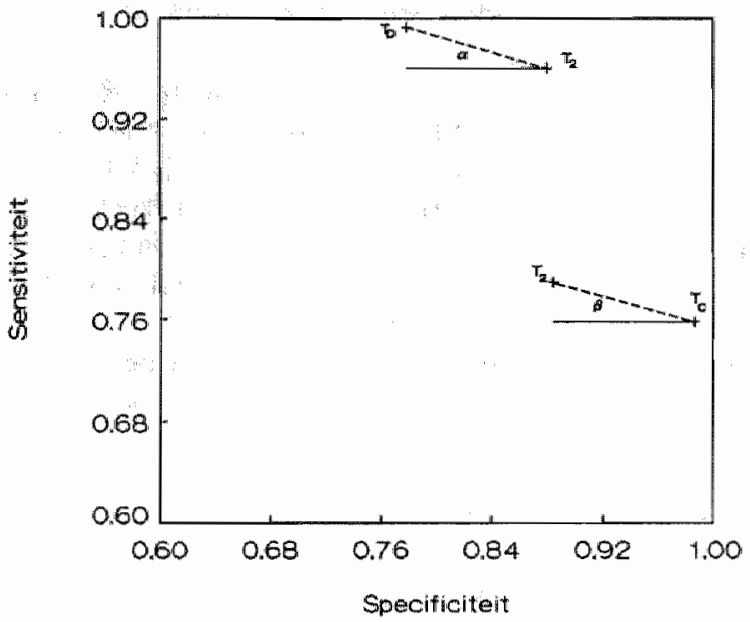

De figuur laat zien wat de maximaal te behalen positie is die bereikt kan worden door twee tests te combineren. Welke combinatie (conjunctief of disjunctief) de voorkeur verdient hangt af van de richtingscoefficiënt (R) (zie voorgaande hoofdstukken).

Bewezen kan worden met gebruikmaking van de formules uit schema 8.3 dat de lijnstukken $T_{D} T_{2}$ en $T_{1} T_{C}$ evenwijdig lopen. De richtingscoefficiënt $\alpha$ (zie figuur) is bijvoorbeeld:

$$
-\frac{\left(\mathrm{Se}_{1}+\mathrm{Se}_{2}-\mathrm{Se}_{1} * \mathrm{Se}_{2}-\mathrm{Se}_{2}\right)}{\left(\mathrm{Sp}_{2}-\mathrm{Sp}_{1} * \mathrm{Sp}_{2}\right)}=-\frac{\mathrm{Se}_{1}\left(1-\mathrm{Se}_{2}\right)}{\mathrm{Sp}_{2}\left(1-\mathrm{Sp}_{1}\right)}
$$


De voorafgaamde formule kan ook geschreven kan worden als volgt:

$$
-L_{1}(+) \cdot L_{2}(-)
$$

Op identieke wijze kan worden aangetoond dat de richtingscoëfficiënt $B$ hieraan gelijk is.

Dit nu maakt het mogelijk om een beknopte beslisregel op te stellen voor het maken van een keuze tussen een conjunctief dan wel een disjunctief criterium.

1. $\quad \mathrm{L}_{1}(+) . \mathrm{L}_{2}(-)<-\mathrm{R}$ neem een conjunctief criterium

2. $L_{1}(+) \cdot L_{2}(-)>-R$ neem een disjunctief criterium

(voor R zie hoofdstuk 6).

Naarmate de a priori kans groter wordt zal de rechterterm (-R) kleiner worden en zal eerder een disjunctief criterium gekozen moeten worden hetgeen in overeenstemming is met de kleinere specificiteit en de grotere sensitiviteit van een dergelijke combinatie. Eveneens zal naarmate de te behalen winst $\left(U_{1}\right)$ groter is eerder cen disjunctief criterium gehanteerd moeten worden.

\subsection{TOEPASSING VAN HET PROGRAMMA OP EEN PRAKTIJKVOORBEELD}

Op basis van de hiervoor ontwikkelde inzichten is een computerprogramma ontwikkeld, waarmee de optimale teststrategie kan worden bepaald.

Voor een toepassing van het programma is gebruik gemaakt van gegevens ontleend aan een artikel van Alderson e.a. (1983). Het artikel heeft betrekking op een prospectieve studie waarbij onder andere de computertomografie (CT) en ultrasound (US) met elkaar vergeleken worden. Een populatie van 189 patiënten, lijdend aan borstkanker $(n=60)$ of colonkanker $(n=129)$, is met minstens twee tests gescreend op het voorkomen van levermetastasen. De uiteindelijke diagnose is gesteld door het vaststellen van levermetastasen bij operatie, biopsie of autopsic. Met de verzamelde data construeren de auteurs voor iedere diagnostische techniek een ROC-curve. Aan de artsen is gevraagd het vertrouwen in de beoordeling uit te drukken in een 5 puntsschaal (zie paragraaf 4.3.).

Een belangrijke conclusie uit het onderzoek van Alderson e.a. is dat de CT de test is met het hoogste onderscheidende vermogen. Dit is het meest duidelijk waar het de opsporing betreft van metastasen van borstkanker. Echter voorzover het metastasen van colonkanker betreft vormt de US op grond van de ROC-curve een goed alternatief voor de CT.

Hieronder staan de resultaten van een economische evaluatie met betrekking tot de opsporing van metastasen van colonkanker. Aangezien de mogelijke afkappunten niet expliciet zijn gepubliceerd, zijn schattingen van de sensitiviteit en de specificiteit verkregen op grond van de ROC-curves. In onderstaande tabel zijn deze schattingen vermeld. 


\begin{tabular}{llllll}
\hline & Afkappunt & & $\mathrm{CT}$ & & \multicolumn{2}{c}{$\mathrm{US}$} \\
& & $\mathrm{Se}$ & $\mathrm{Sp}$ & $\mathrm{Se}$ & $\mathrm{Sp}$ \\
\hline 1 & .875 & .95 & .56 & .94 \\
2 & .91 & .93 & .70 & .92 \\
3 & .96 & .88 & .79 & .885 \\
4 & .97 & .835 & .82 & .85 \\
5 & .98 & .79 & .91 & .65 \\
6 & - & - & .94 & .46 \\
\hline
\end{tabular}

In het Academisch Ziekenhuis Maastricht zijn de kostprijzen bepaald voor deze diagnostische technieken. Voor het bepalen van de kostprijs is alleen gebruik gemaakt van de directe kosten. Voor CT bedragen deze $f 270$, en voor US $f 62,68$. Inclusief de honoraria voor de arts bedragen de kostprijzen respectievelijk $f 430$,- voor de CT en $f$ 150,- voor de US. De kosten van de behandeling worden gesteld op $f$ 5000,-. Overigens zal met behulp van gevoeligheidsanalyses de invloed van de hoogte van de testen behandelingskosten op de optimale strategie nader worden vastgesteld.

\section{Risico's van de tests}

Het risico ten gevolge van het uitvoeren van de US techniek is te verwaarlozen. Het risico bij een CT (stralenbelasting en overgevoeligheid voor töntgencontrastmiddelen) wordt verwaarloosbaar klein geacht.

\section{De gezondheldseffecten van de behandeling}

De gezondheidswinst, die behald kan worden door behandeling van een persoon die aan de ziekte leidt, kan in principe uitgedrukt worden in QALY's. Daarbij is het nodig een schatting te maken van het gemiddelde levens-verlengende effect van de behandeling (het aantal toegevoegde levensjaren) als ook van de kwaliteit van het leven gedurende de resterende jaren. Van deze laatstgenoemde factor kunnen schattingen gemaakt worden middels zogenaamde utiliteitsanalyses (Torrance, 1986).

In het onderhavige geval is niet een apart utiliteitsonderzoek verricht, maar is gebruik gemaakt van een schatting van deze parameters door een arts. Deze schattingen zijn hooguit te beschouwen als globale indicaties wan de werkelijke gezondheidseffecten. In een gevoeligheidsanalyse zal worden nagegaan wat de invloed is van deze schattingen op de modeluitkomsten. In het model wordt uiteindelijk slechts gerekend met een tweetal variabelen: $U_{1}$ en $U_{2}$ (zie hoofdstuk 7). De factor $U_{1}$ is de te behalen gezondheidswinst die verkregen kan worden door een zieke te behandelen, terwijl de $\mathrm{U}_{2}$ staat voor het verlies aan gezondheid door het behandelen van een gezond persoon. 
Indien een metastase in de lever wordt aangetoond is er sprake wan cen zeer slechte prognose voor de patiènt.

In een enkel geval behaalt men met behandeling enkele jaren levenswinst met een kwalitatief betere toestand ten opzichte van geen behandeling. Een speciallist uit het Academisch Ziekenhuis Maastricht maakte de volgende schattingen:

De winst van de behandeling heeft meer te maken met de verbetering van de gezondheidstoestand gedurende de resterende jaren dan met een levensverlenging. Het gemiddeld aantal te leven jaren is zeer gering. De meeste patiënten zullen zijn overleden binnen 2 aे 3 jaar. De totale winst van de behandeling wordt geschat op 8 QALY's.

Verlies aan gezondheid bij behandelen gezond persoon $\left(\mathrm{U}_{2}\right)$

Indien een bepaald persoon ten onrechte behandeld wordt, betekent dit een inbreuk op de gezondheidssituatie van de betreffende persoon. In eerste instantie wordt in de berekening uitgegaan van $U_{2}=-.02$, waarbij ook weer met behulp van een gevoeligheidsanalyse de invloed van deze aanname wordt nagegaan.

\subsection{RESULTATEN BASISMODEL}

Voor de berekeningen is een speciaal computerprogramma ontwikkeld. Dit programma is in principe zo opgebouwd dat voor iedere a priori kans bepaald kan worden welke teststrategie de beste is en welk(e) afkappunt(en) gehanteerd zou(den) moeten worden. Hieronder worden de resultaten van de twee verschillende optimaliseringscriteria afzonderlijk besproken. Bij beide berekeningen is het nodig een bepaalde maximumwaarde aan te nemen voor een QALY. Voor de O-K berekening is dit noodzakelijk omdat op deze wijze opbrengsten en kosten op een en dezelfde noemer kunnen worden gebracht. Bij de $\mathrm{K} / \mathrm{O}$ berekening kan het zo zijn dat een bepaalde strategie weliswaar de optimale strategie is, maar dat de QALY's, op deze wijze geproduceerd, in maatschappelijk opzicht te duur zijn. "Niets doen" is dan toch de te verkiezen strategie. In het basismodel is voor een QALY de waarde $f 10.000,-$ meegenomen, maar ook van deze aanname is de invloed nagegaan middels een gevoeligheidsanalyse.

\subsubsection{Opbrengsten-kosten}

Afhankelijk van de a priori kans is er een vijftal strategieèn welke in de optimale oplossing verschijnen. Naast de strategieen "niets doen" en "onmiddellijk behandelen" zijn dit drie teststrategieën. In de onderstaande figuiur is dit schematisch weergegewen. 


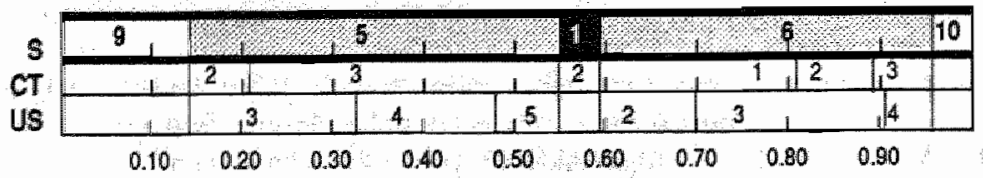

In de respectievelijke balken in de aguren, zijn de modeluitkomsten weergegeven voor alle waarden wan a priori kansen ( $p$ loopt van 0 tot 1 ). In de bovenste dik omilijnde balk is met cijfers welke corresponderen met de hiervoor gedefinieerde teststrategieẻn (zie paragraaf 8.2) aangegeven binnen welk gebied van p-waiarden een bepaialde strategie de optimale strategie is. Met nummer 9 wordt de strategie "niets doen" aangeduid, met 10 de strategie "onmiddellijk behandelen". Test 1 is de CT en test 2 de US.

In de twee lichtere balken in de figuur is met behulp van een nummering aangegeven voor de CT respectievelijk de US welk afkappunt gehanteerd zou moeteri wonden. De nummering van de afkappunten staat vermeld in tabel 8.2.

Bijvoorbeell" voor $p$ is .35 staan in bowenstaande figuur de cijfers 5,3 en 4 onder elkaar vermeld. 5 impliceert stratiegie 5 , hetgeen in dit geval betekent: eerst US uitwoeren, indien deze positief is dan bog CT verrichten.

Bij CT dient men afkappunt 3 te hanteren ( $\mathrm{Se}=.96_{\mathrm{n}} \mathrm{Sp}=88$ ). De US heeft als afkappunt $4(\mathrm{Se}=.82, \mathrm{Sp}=85)$.

Voor verreweg het grootste gedeelte van de a priori kansen geldt dat een teststrategie optimaal is. Voor p-waarden kleiner dan .13 is "niets doen" te verkiezen en voor pwaarden groter dan 94 heeft "onmiddellijk behandelen" de voorkeur.

In een relatief klein gebied heeft uitvoering van de $\mathrm{CT}$ alleén de voorkeur.

Voor het overige heeft serietesten de voorkeur, waarbij eerst de goedkope test uitgevoerd dient te worden. Voor p-waarden kleiner dan .54 dient na de goedkope test de duurdere test uitgevoerd te worden, indien de eerste test positief is. Voor $\mathrm{p}$-waarden groter dan .58 dient deze duurdere test uitgevoerd te worden, bij een negatieve eerste testuitslag.

In de volgorde van teststrategieen is er sprake van een toenemende sensitiviteit (eventueel van de combinatie van tests) en een dalende specificiteit. $Z o$ is de sensitiviteit van strategie 1 groter dan van de strategie 5 en hetzelfde geldt voor strategie 6 ten opzichte van strategie 1 .

Twee opmerkingen zijn hierbij te maken. In de eerste plaats is het zo dat een conjunctief positiviteitscriterium leidt tot een lage sensitiviteit en hoge specificiteit. Dat een dergelijke combinatie de voorkeur verdient bij lage prevalenties is te verwachten (zie 8.3.2). Eveneens is het te verwachten dat een serie combinatie met een disjunctief criterium bij hoge a priori kansen de beste strategie wordt. Een tweede opmerking die hier overigens mee samenhangt is het volgende. Bij lage a priori kansen ligt het voor de hand dat vooral na een positieve uitslag een vervolgactie nodig is. Een negatieve testuitslag wekt bij lage a priori kansen geen argwaan. Na een positieve testuitslag is de kans op de ziekte toegenomen en is de mogelijkheid aanwezig dat de betreffende 
a posteriori kans zich bevindt in het gebied waar de tweede test een positieve opbrengst vertoont. Eenzelfde redenering geldt voor hoge a priori kansen waar met mame een negatieve uitslag een vervolgactie noodzakelijk maakt.

Een en ander kan nader worden verduidelijkt aan de hand van de grafische methode (zie figuur 8.1 en 8.2 ). Voor $\mathrm{p}$-waarden tussen $\pm .1 \mathrm{en} .55$ heeft de richtingscosfficient $R$ van de raaklijn waarden tussen respectievelijk -.2 en -.02 . Wordt alleen gekeken naar de opbrengstenkant, dan blijkt zoals in hoofdstuk 7 is uiteengezet de maximale opbrengst gerealiseerd te worden bij de conjunctieve testcombinaties. Is de p-waarde groter dan " 6 dan is de $R$-waarde zodanig dat de raaklijn bijna horizontaal verloopt. De grafiek maakt het aannemelijk dat bij cen p-waarde van \pm .55 (en een corresponderende waarde van $R$ van -.02 ) het apart uitvoeren van de CT (strategie 1) de hoogste opbrengst vertoont.

In de bovenstaande analyse zijn de kosten niet meegerekend. De kosten van de respectievelijke seriestrategieèn zijn afhankelijk van de sensitiviteit en specificiteit van het betreffende eerste test en zijn per combinatie verschillend. In de grafische methode is dit niet zo eenvoudig mee te nemen. Indien de kosten van de test relatief gering zijn ten opzichte van de te behalen opbrengst, zoals in dit voorbeeld het geval is, leidt de grafische methode tot een goede benadering van de optimale situatie.

Binnen de aldus gevonden gebieden, waarbinnen de genoemde strategieen prevaleren, is een nadere specificatie te geven omtrent de te hanteren optimale afkappunten. Bij een QALY-waarde van $f 10.000$,- speelt het probleem van het optimale afkappunt met name bij toepassing van strategie 5 en strategie 6 (zie figuur 8.6).

Algemeen geldt dat er een afkappunt gekozen moet worden met een hogere sensitiviteit (en dus lagere specificiteit) naarmate de a priori kans toeneemt. Dit geldt zowel voor de eerste test als voor de eventuele vervolgtest.

In het onderstaande overzicht staan de optimalle combinaties vermeld voor het gebied waar strategie 6 te prefereren is:

Tabel 8.3. Optimale afkappunten binnen strategie 6

\begin{tabular}{lll}
\hline $\begin{array}{l}\text { Optimale afkappunten } \\
\text { wäarde van } \mathrm{p}\end{array}$ & US & CT \\
\hline $59-.69$ & 2 & 1 \\
$.69-.80$ & 3 & 1 \\
$80-.87$ & 3 & 2 \\
$.87-.91$ & 3 & 3 \\
$.91-.93$ & 4 & 4 \\
\hline
\end{tabular}

De afkappunten mel een hoger rangnummer worden gekenmerkt door een hogere sensitiviteit en lagere specificiteit (zie tabel 8.2). In onderstaande figuur, welke de "geprojecteerde" ROC-curves bevat van alle disjunctieve combinaties van afkappunten, is aangegeven welke combinaties in de optimale oplossing voorkomen. "Te zien is dat in de optimale oplossing niet altijd de buitenste afkappunten voorkomen, hetgeen 
verwacht zou mogen worden op grond van de grafische methode. Een en ander wordt veroorzaakt door variêrende kosten wan de teststrategieën.

Figuur 8.6. "Geprojecteerde" ROC-curves, disjunctieve combinaties plus optimale combinaties (criterium $\mathrm{O}-\mathrm{K}$ )

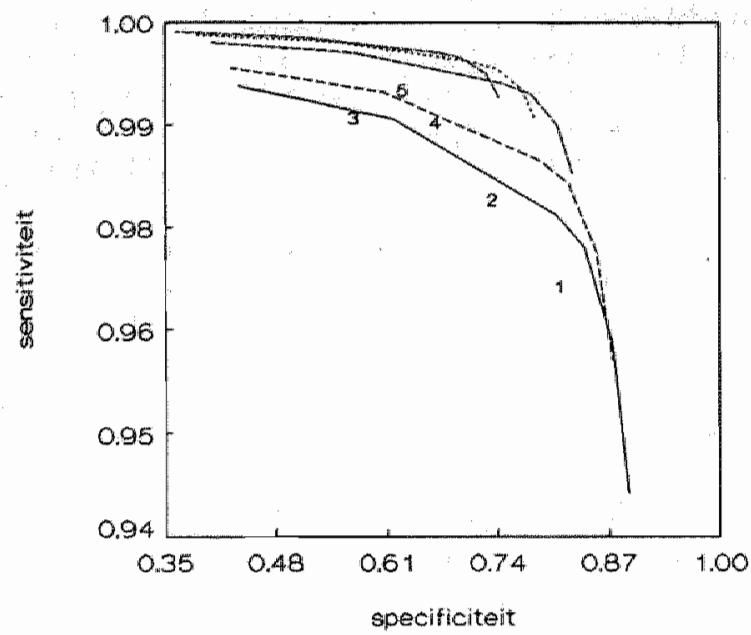

\section{Kosten/opbrengsten}

Indien als criterium voor optimalisatie van het testgebruik het kosten/opbrengsten criterium wordt gehanteerd zijn de strategieën afwijkend. Aangezien per definitie in dit model geen kosten zijn verbonden aan het alternatief "niets doen" blijft deze mogelijkheid buiten beschouwing in de vergelijking. In feite worden de extra opbrengsten van de strategieèn vergeleken met de extra kosten ten opzichte van het alternatief "niets doen" en dit wordt in een verhoudingsgetal uitgedrukt $(\delta \mathrm{K} / \delta O)$.

Deze verhouding geeft aan hoeveel kosten extra gemaakt moeten worden voor het produceren van een extra QALY. Uit de berekeningen blijkt dat de $\mathrm{K} / \mathrm{O}$ verhouding daalt naarmate de a priori kans toeneemt, met andere woorden, het is altijd kosteneffectiever om een persoon met een hogere kans op de ziekte op te sporen en te behandelen dan een persoon met een lagere kans op de ziekte. Voor $\mathrm{p}=.1$ bedragen de kosten per QALY bijwoorbeeld $f 10.770,-$ bij $\mathrm{p}=.2 f 8.813,-$, terwijl deze kosten bij $\mathrm{p}=.9$ zijn gedaald tot $f 6.617,-$.

Samenvattend kan gesteld worden dat bij lage waarden van $p(p<.12)$ "niets doen" de beste strategie is en voor hoge waarden $(p>96$ ) "onmiddellijk behandelen". Verder is strategie 5 de beste strategie indien $p<.53$ en 4 indien $p>.53$. Het resultaat met betrekking tot strategie 4 en 5 kan als volgt worden samengevat. Voor p-waarden tussen .12 en .96 dient de US uitgevoerd te worden, waarbij deze nog gevolgd moet worden door een CT indien de p-waarde tussen .12 en .53 ligt en de US positief is. Wat betreft de hantering van afkappunten in de K/O benadering is het zo, dat indien strategie 5 optimaal is, ongeveer dezelfde afkappunten optimaal zijn als bij de $O-K$ benadering. $\mathrm{Bij}$ de $\mathrm{K} / \mathrm{O}$ benadering zijn de grenzen naar rechts verschoven, hetgeen 
impliceert dat er ten opzichte van de $\mathrm{O}-\mathrm{K}$ benadering afkappunten met een hogere specificiteit worden gebruikt. Uit hoofdstuk 6 blijkt dat dit niet altijd zo hoeft te zijn (zie bijwoorbeeld figuur 6.4).

Figuur 8.7. Basismodel K/O

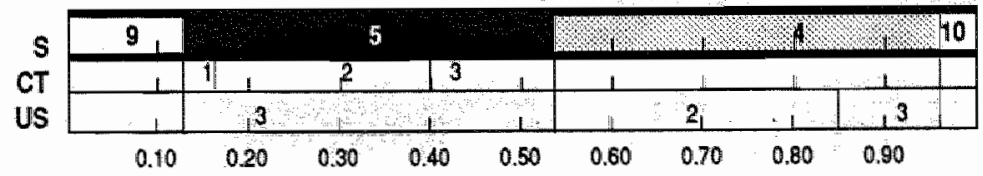

Worden de resultaten van het $\mathrm{K} / \mathrm{O}$ criterium vergeleken met de resultaten van de $\mathrm{O}$ $\mathrm{K}$ dan valt op dat bij de $\mathrm{K} / \mathrm{O}$ optimalisering over het algemeen genomen minder diagnostische middelen worden gebruikt dan bij $\mathrm{O}-\mathrm{K}$ het geval is. Dit is een fenomeen dat in overeenstemming is met de redenering uit hoofdstuk 6 . waar de optimale produktie-omvang bij $\mathrm{O}-\mathrm{K}$ en $\mathrm{K} / \mathrm{O}$ ter sprake is gekomen.

In de beschouwing van dit hoofdstuk zal hierop nog uitgebreid worden ingegaan.

\subsubsection{Resultaten met betrekking tot de opsporing van borstkankermetastasen}

In het artikel van Alderson e.a worden niet alleen de ROC-curves gepresenteerd van tests met betrekking tot de opsporing van metastasen van colon-kanker, maar ook van borstkanker. In beide toepassingsgebieden lijkt de CT de test te zijn met het hoogste onderscheidend vermogen. De US vertoont bij colonkanker een ROC-curve die de ROC-curve van de CT enigszins benadert, terwijl de ROC-curve met betrekking tot het opsporen van borstkankermetastasen duidelijk inferieur is. Een en ander is verklaarbaar op grond van de verschijningsvormen van beide typen metastasen, waarbij het colonkanker vaak een duidelijke metastase veroorzaakt, terwijl er bij metastasering van borstkanker sprake is van meerdere en soms talloze kleine uitzaaiingen. Dit heeft ertoe geleid dat in het Academisch Ziekenhuis Maastricht US bij opsporing van metastasen wan colonkanker wel geadviseerd wordt maar bij borstkanker niet.

Bovenstaande berekeningen, welke betrekking hadden op de opsporing van colonmetastasen zijn ook uitgevoerd met betrekking tot opsporing van borstkankermetastasen, teneinde na te gaan hoe groot de invloed is van de vorm van de ROC-curve op de optimale strategieen.

Op grond van het feit dat de US een gering onderscheidend vermogen heeft ten opzichte van de $C T$, mag op voorhand verwacht worden dat de strategieën waarin US voorkomt nu minder zullen voorkomen. Uit de berekeningen met het criterium $\mathrm{O}-\mathrm{K}$ blijkt dat dit met name resulteert in een groter gebruik van CT als aparte test, terwij» strategieèn 5 en 6 minder voorkomen. Bij de $\mathrm{K} / \mathrm{O}$ berekeningen blijkt "alleen uitwoeren van $\mathrm{US}^{\text {"t }}$ vervangen te worden door "alleen uitwoeren van $\mathrm{CT}^{\mathrm{t}}$. 
Figuur 8.8. Optimale strategieen met betrekking tot opsporing borstkanker O-K en K/O
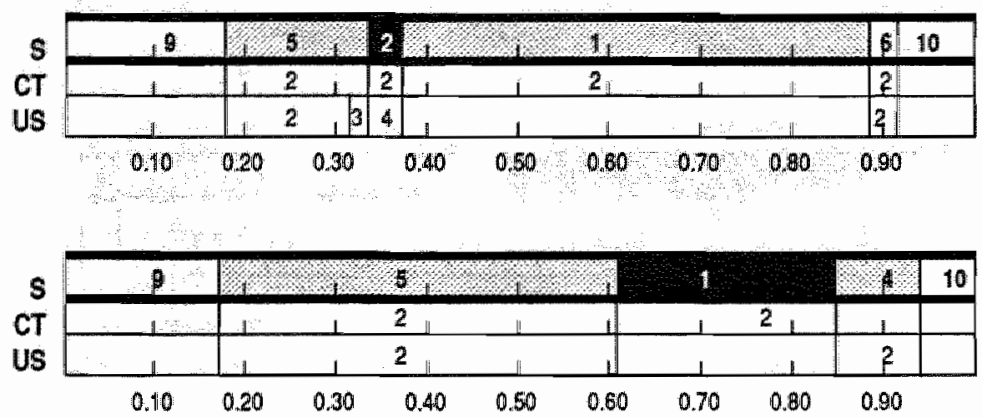

Ook hier zien we dat hantering van het criterium $\mathrm{K} / \mathrm{O}$ leidt tot een zuiniger inzet van diagnostische middelen, hetgeen tot uitdrukking komt in met name het gering gebruik van strategie 1 (het hanteren van de dure test).

In de navolgende gevoeligheidsanalyses worden alleen de resultaten gepresenteerd met betrekking tot colonkanker.

\subsection{GEVOELIGHEIDSANALYSES}

\subsubsection{Gevoeligheidsanalyse van de waarde van een QALY}

\section{Opbrengsten-kosten}

Indien de waarde van een QALY toeneemt, vermeerdert ook de in geld uitgedrukte opbrengst. Door deze veranderingen aan de opbrengstenkant kunnen ook de gebieden verschuiven waarbinnen strategieën optimaal zijn. In onderstaande figuur is een overzicht gegeven van de invloed van de waarde van een QALY voor de optimale strategie bij het criterium $\mathrm{O}-\mathrm{K}$. 
Figuur 8.9. Gevoeligheidsanalyse $\mathrm{QALY}$, criterium $\mathrm{O}-\mathrm{K}$

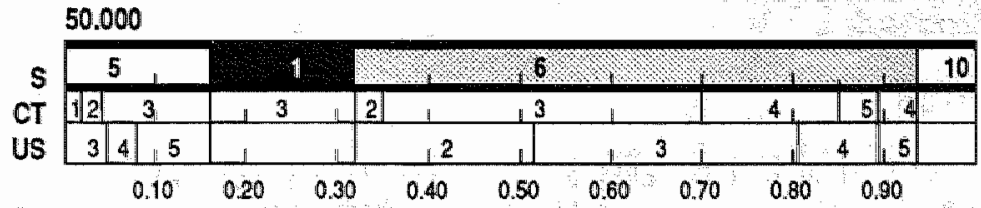

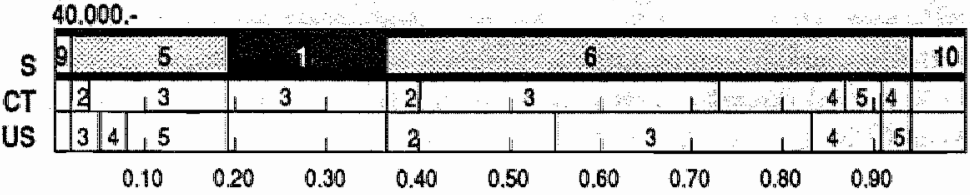

30.000.

\begin{tabular}{|c|c|c|c|c|c|c|c|c|c|c|}
\hline 5 & 5 & & 1 & & & & & 6 & & 10 \\
\hline $\mathrm{CT}$ & $2+3$ & 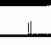 & 3 & 2 & $\perp$ & $3_{1}$ & 1 & & 4.1 & \\
\hline US & 3 & $s_{1}$ & 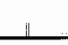 & 2 & $B$ & 2 & .3 & & 4 & \\
\hline & 0.10 & 0.20 & 0.30 & 0.40 & 0.50 & 0.60 & 0.70 & 0.80 & 0.90 & \\
\hline
\end{tabular}

$20.000-$

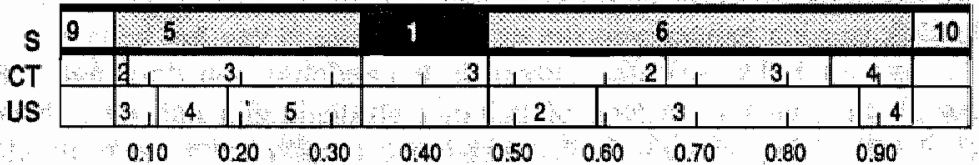

10.000.

\begin{tabular}{|c|c|c|c|c|c|c|c|c|c|c|}
\hline \multirow{3}{*}{$\begin{array}{r}S \\
\text { CT } \\
\text { US }\end{array}$} & 9 & \multicolumn{4}{|c|}{6} & $1 \%$ & \multicolumn{3}{|c|}{ G } & 10 \\
\hline & 1. & 2. & & 1 & 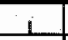 & 2 & 4 & 2 & -3 & \\
\hline & 1 & & 3 & 4 & 15 & $I_{1}$ & 2 & $1^{3}$ & 4 & \\
\hline & 0.10 & 0.20 & & 0.40 & 0.50 & 0.60 & 0.70 & 0.80 & 0.90 & \\
\hline
\end{tabular}

In zijn algemeenheid kan gesteld worden dat naarmate de waarde van een QALY groter is, alle testgrenzen verschuiven in de richting van lagere a priori waarden. Het gebied, waarbinnen het alternatief "niets doen" prevaleert, wordt daardoor steeds kleiner en komt bij waarden groter dan $f 50.000$,- niet meer voor. Aan de andere kant blijft het gebied waar onmiddellijk behandelen prevaleert nagenoeg constant. Dit betekent dat teststrategieën in economische zin steeds meer haalbaar worden voor patiëntengroepen met een lagere kans op de ziekte, naarmate een groter gewicht toegekend wordt aan de te behalen opbrengst van de behandeling.

Opmerkelijk is verder dat het gebied waar het uitvoeren van CT optimaal is, groter wordt en verschuift naar lagere waarden van $p$. Uitvoering van een relatieve dure test apart wordt dus relatief aantrekkelijker.

De gevoeligheid voor de factor QALY is aanzienlijk te noemen. Daarbij is het bovendien zo dat er met name met betrekking tot de hoogte van deze factor weinig eensgezindheid bestaat. $\mathrm{Er}$ is op dit moment nog te weinig (Nederlands) onderzoek 
beschikbaar waaruit een waardebepaling voor een QALY zou kunnen worden afgeleid. De berekende optimale strategieën zijn dan ook met name vanuit een theoretisch oogpunt interessant.

\section{Gevoellgheldsanalyse}

\section{Kosten/opbrengst}

De gevoeligheidsanalyse met betrekking tot de waarde van een QALY bij het K/O criterium laat een geheel ander beeld zien. In feite blijven nu exact dezelfde testcombinaties met exact dezelfde afkappunten optimaal, waarbij ook de grenzen tussen de strategieen onveranderd blijven, hetgeen ook te verwachten is. De testkosten blijven identiek, terwijl de opbrengst met de factor $M$ wordt vermenigvuldigd, hetgeen de prioriteitsvolgorde van de tests niet beïnvloedt.

\subsubsection{Gevoeligheidsanalyse met betrekking tot kosten van behandeling}

\section{Opbrengsten-Kosten}

In de uitgangsberekeningen zijn de kosten van behandeling gesteld op $f 5.000,-$. Alleen de testpositieven krijgen deze behandeling. Aangezien de winst van behandelen slechts .8 QALY bedraagt en de waarde van de QALY in de uitgangspositie $f 10.000$,- is, kan reeds onmiddellijk worden aangegeven dat er geen sprake is van het behalen van een positieve opbrengst bij zieke personen indien de behandeling van de ziekte $f 8.000$,of meer bedraagt. In geen enkele test- of behandelstrategie zijn dan de opbrengsten groter dan de kosten. In onderstaand overzicht is weergegeven hoe de optimale teststrategieën veranderen onder invloed van de verandering van de kosten van behandeling. 
Figuar 8.10. Gevoeligheidsanalyse kosten behandeling, criterium $\mathrm{O}-\mathrm{K}$

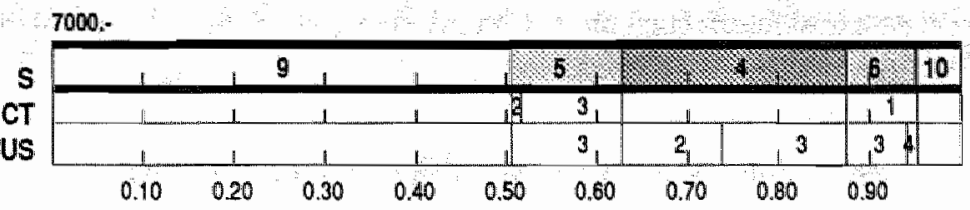

6000-

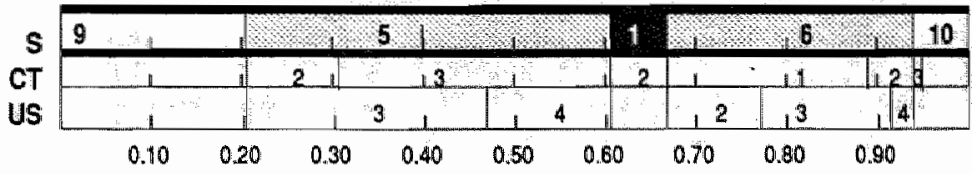

5000.-

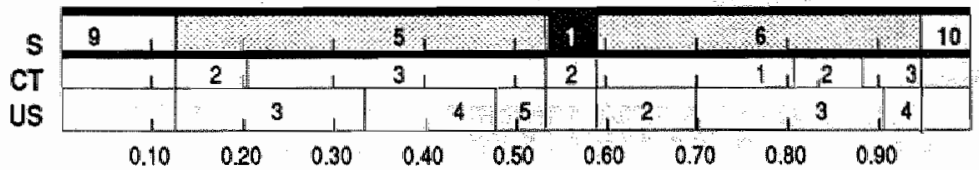

4000.-

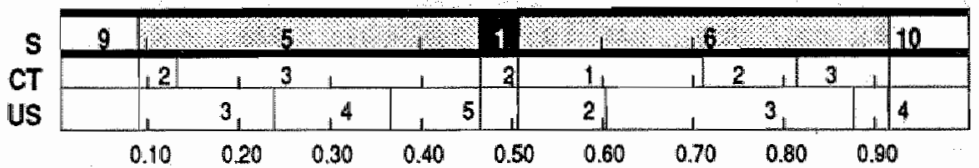

3000.-

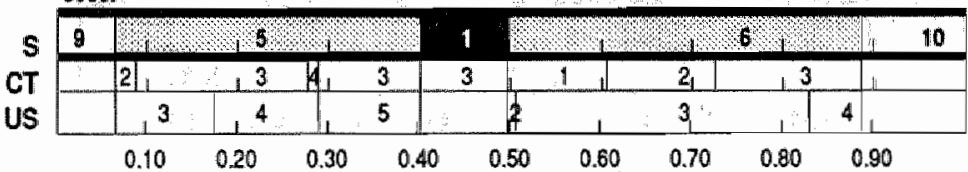

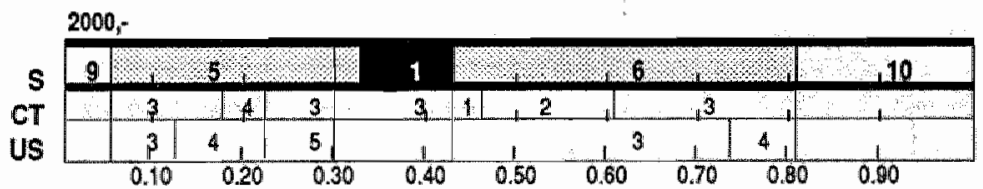

$\mathrm{Er}$ is een groot aantal veranderingen te constateren. In de eerste plaats wordt naarmate de behandelingskosten toenemen (van $f$ 2.000,- naar $f 7.000,-$ ), "niets doen" aantrekkelijker (voor lage prevalenties) en het "onmiddellijk behandelen" minder aantrekkelijk (voor hoge prevalenties). Naarmate de behandelingskosten toenemen, neemt de te behalen winst af. Dit heeft tot gevolg dat de grenzen, waarbinnen teststrategieèn relevant zijn, nauwer worden. Een toename van de kosten van behandeling heeft naar verwachting eenzelfde effect als een afname van de te behalen winst bij behandeling (zie volgende subparagraaf).

Zijn de behandelingskosten groter dan $f 6.000$,- dan verdwijnt strategie 1 , uitwoering van $C$, uit de optimale oplossing. Temidden van de strategieen 5 en 6 dient in plaats van CT de US uitgevoerd te worden. Geconcludeerd kan worden dat de invloed van de kosten van behandeling op de optimale strategie groot is. 


\section{Kosten/opbrengsten}

Naarmate de kosten wan een behandeling dalen, zal ceteris paribus het uitvoeren van teststrategieën een kosten-effectief alternatief worden, ook voor lage waarden van a priori kansen.

Figuur 8.11. Gevoeligheidsanalyse kosten behandeling, criterium K/O

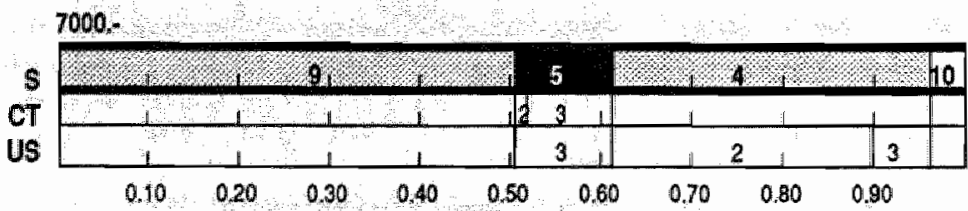

6000 .

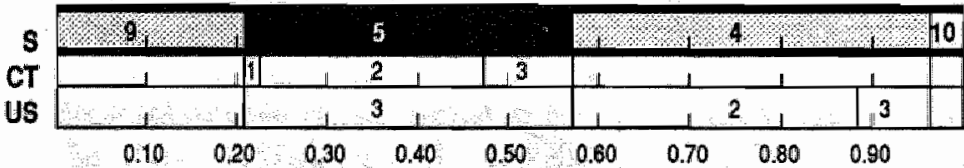

5000.

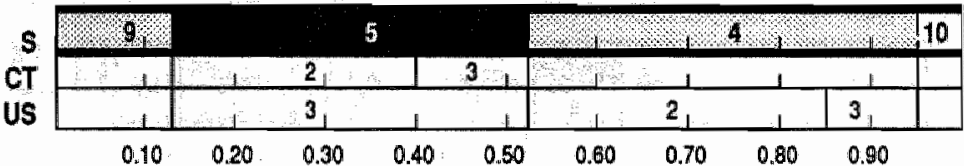

4000.
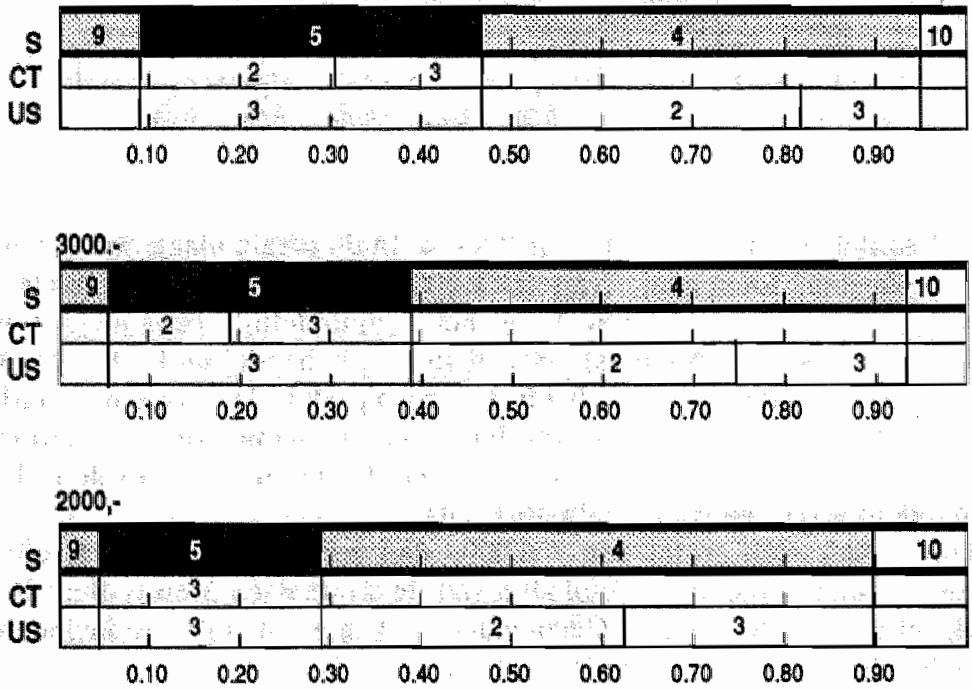
Met name uitwoering van de US is optimaal in een steeds groter gebied van p-waarden, naarmate de kosten van behandeling geringer worden. In de totale oplossing verschijnen nu veel minder verschillendle strategieen dan het geval is bij optimalisering via $\mathrm{O}-\mathrm{K}$. De US is blijkbaar in dit geval voor de opsporing van colonkanker een kosten-effectief alternatief voor $\mathrm{CT}$, onafhankelijk van de behandelingskosten.

\subsubsection{Gevoeligheidsanalyse winst behandelen $\left(\mathrm{U}_{1}\right)$}

De resultaten met betrekking tot verandering in de variabele $U_{1}$ leveren weinig extra informatie op ten opzichte van de voorgaande subparagraaf. Het blijkt dat het veranderende beeld van de optimale strategieën exact gelijk is aan de voorgaande resultaten, hetgeen zelfs geldt voor de te hanteren afkappunten. Een stijging in de winst bij behandelen heeft hetzelfde effect als een daling in de behandelingskosten. Nu geldt dat indien de te behalen winst bij een behandeling kleiner wordt dan .5 QALY, er geen positief effect resulteert bij een QALY-waarde van $f 10.000^{-}$, aangezien de behandelingskosten reeds $f 5.000$,- bedragen. Dezelfde conclusie blijkt voor het criterium kosten/opbrengsten.

\subsubsection{Gevoeligheidsanalyse winst ten onrechte behandelen $\left(\mathrm{U}_{2}\right)$, criterium $\mathrm{O}-\mathrm{K}$}

Over het algemeen is de gevoeligheid van deze factor niet groot te noemen. Ten opzichte van de factor $\mathrm{U}_{1}$ legt $\mathrm{U}_{2}$ nawwelijks gewicht in de schaal. Er moet al een grote variatiebreedte genomen worden wil het totale beeld veranderen. Algemeen geldt dat strategie 5, 1 en 6 vrijwel stabiel blijven.

Figuur 8.12. Gevoelligheidsanalyse $\mathrm{U}_{2}$, criterium $\mathrm{O}-\mathrm{K}$
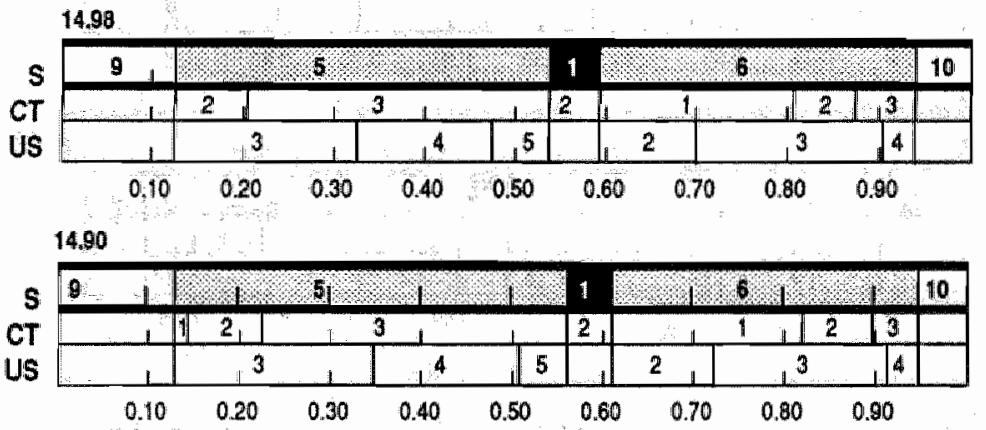

Bij het $\mathrm{K} / \mathrm{O}$ criterium spelen veranderingen in $\mathrm{U}_{2}$ geen rol van betekenis. 


\subsubsection{Gevoeligheidsanalyse kosten US, criterium O-K}

In hoofdstuk 5 is gebleken dat de kosten van de tests een belangrijke invloed kunnen uitoefenen op de optimale strategie. Daarbij is het met name de verhouding tussen testkosten die van belang is. In de gevoeligheidsanalyse met betrekking tot kosten van tests zijn de kosten van de goedkope US in stappen opgehoogd van $f 150$,- tot $f 360$,-Bij dit niveau komt de US niet meer voor in de optimale strategieën. Gegeven het geringe onderscheidende vermogen van de test en de geringe kostenverschillen met de CT is de uitwoering van de US in dat geval voor geen enkele p-waarde interessant.

Figuur 8.13. Gevoeligheidsanalyse kosten US, criterium O-K
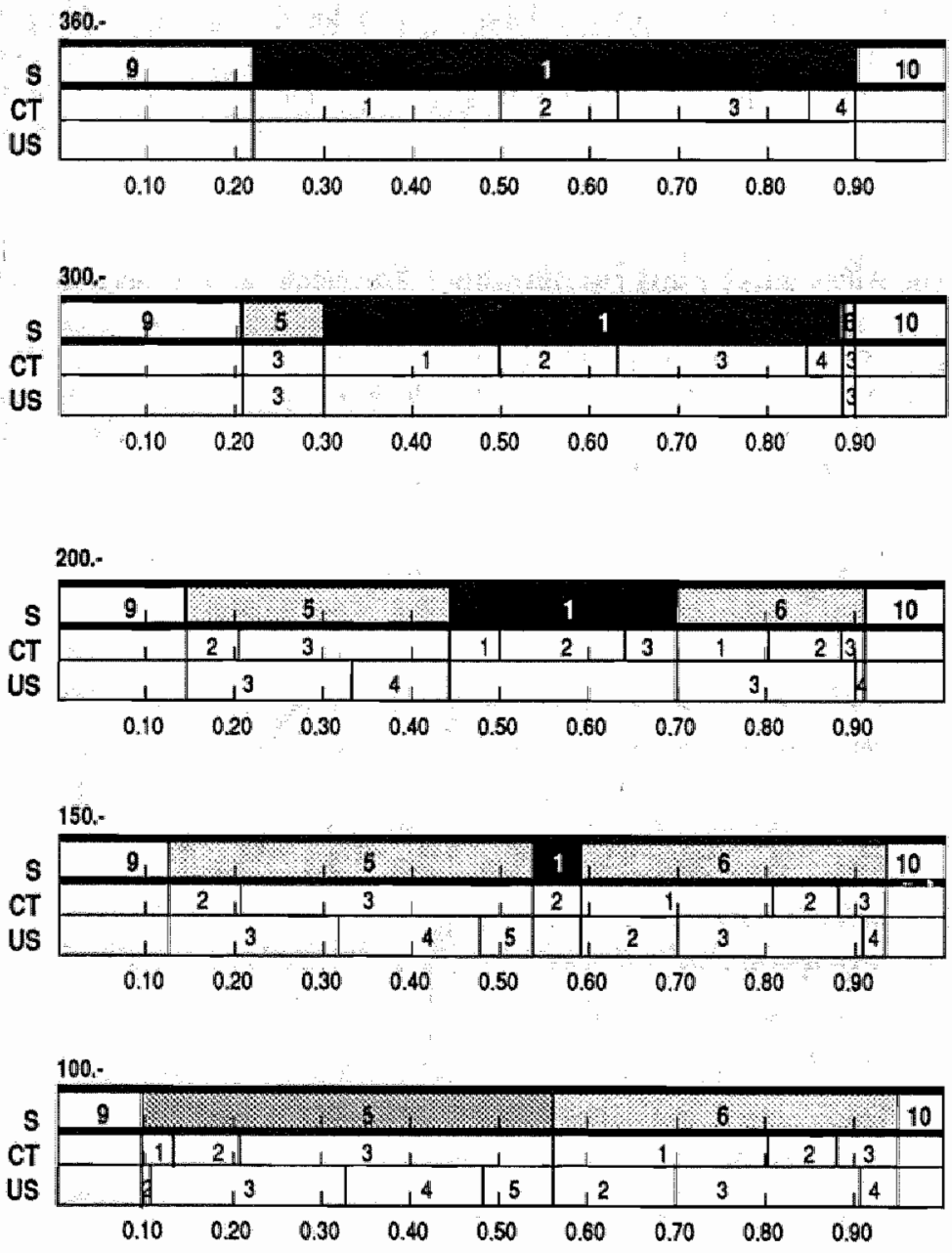

Uit deze gevoeligheidsanalyse blijkt dat de relatieve kostenverhouding van groot belang is voor het bepalen van de optimale strategie. 


\section{Criterium K/O}

Wordt de invloed nagegaan van de hoogte van de kosten van de US op de optimale strategie volgens het criterium K/O dan blijkt $C T$ eveneens in de optimale oplossing te verschijnen bij hogere waarden. Dit gebeurt echter pas bij veel hogere kosten dan bij het criterium $\mathrm{O}-\mathrm{K}$. Ook dit is weer een bevestiging van het feit dat optimalisering volgens $\mathrm{K} / \mathrm{O}$ leidt tot cen "geringere" inzet van diagnostische middelen dan optimalisering volgens $\mathrm{O}-\mathrm{K}$. Het effect van de extra opbrengst van $\mathrm{CT}_{\text {, welke het gevolg }}$ is van het betere onderscheidende vermogen van de CT, weegt relatief niet op tegen de lagere kosten van de US, Om de $K / O$ verhouding van de CT op hetzelfde niveau te krijgen als de $\mathrm{K} / \mathrm{O}$ verhouding van US moet de opbrengst van de $\mathrm{CT}$ driemaal zo hoog zijn als de opbrengst van de US.

Figuur 8.14. Gevoeligheidsanalyse kosten US, criterium K/O

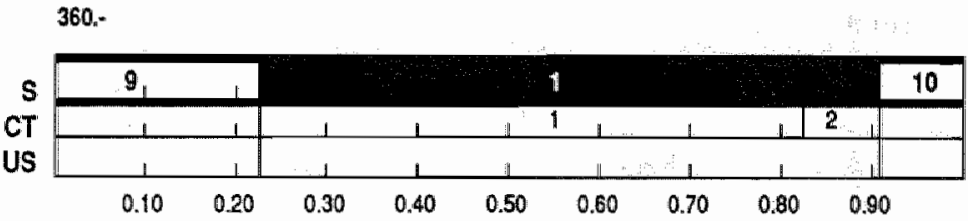

300.-

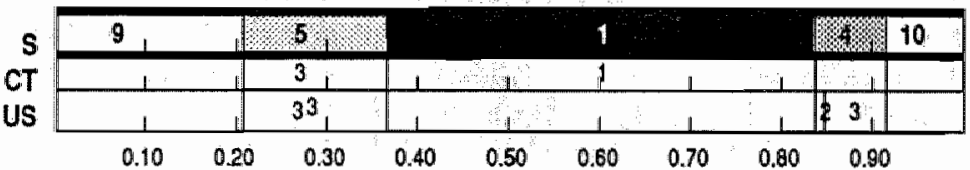

200..

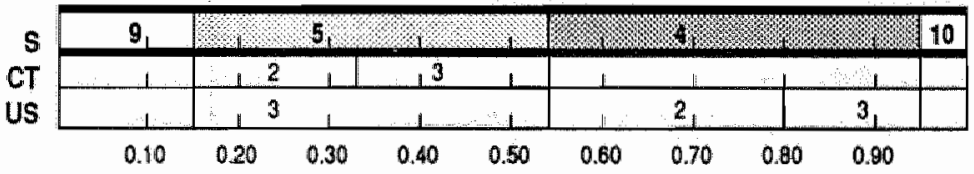

150.-

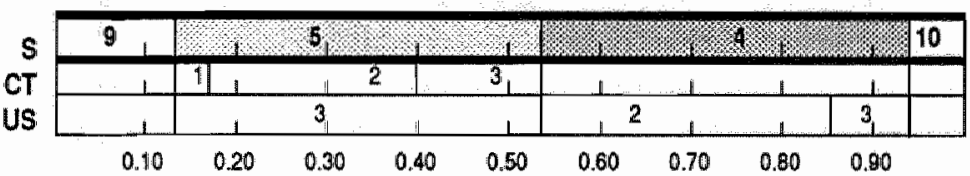

100.-

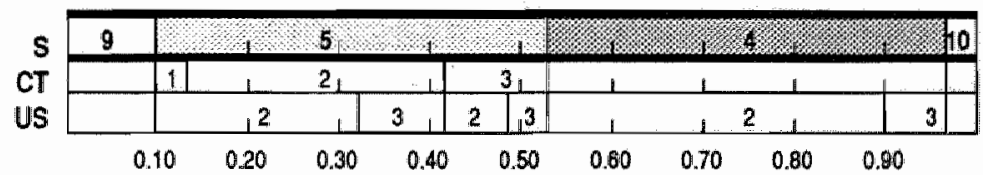




\subsection{BESCHOUWING}

De uittkomsten van de voorafgaande berekeningen kunnen worden samengevat in de vorm van protocollen. Daarbij resteert overigens nog het probleem dat er sprake is van minimaal twee protocollen; een protocol waarin $\mathrm{O}-\mathrm{K}$ wordt gemaximaliseerd en een protocol waarin $\mathrm{K} / \mathrm{O}$ wordt geminimaliseerd.

Hieronder zijn de respectievelijke protocollen weergegeven behorende bij de basisgegevens:

\section{Toelichting protocollen}

In deze protocollen is de a priori kans de beslissingsvariabele. Achtereenwolgens wordt nagegaan of deze a priori kans een bepaalde drempel overschrijdt. De beslissingen ten aanzien van de te hanteren afkappunten zijn niet opgenomen in de protocollen.

\section{Figuwr 8.15. Protocol O-K}

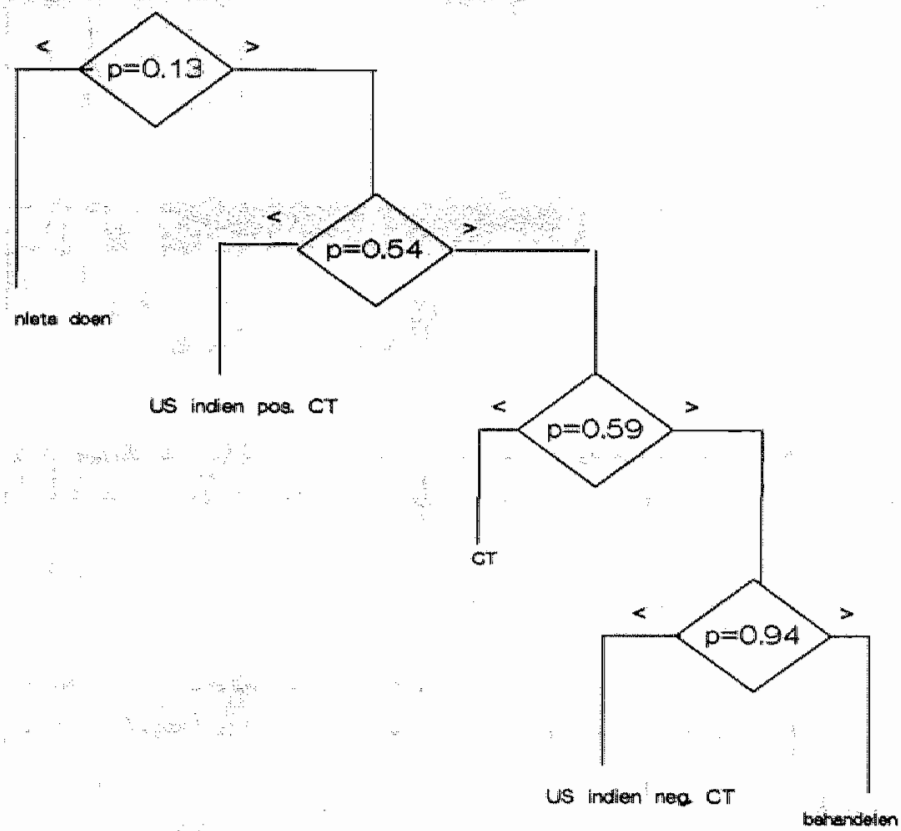


Figuur 8.16. Protocol K/O

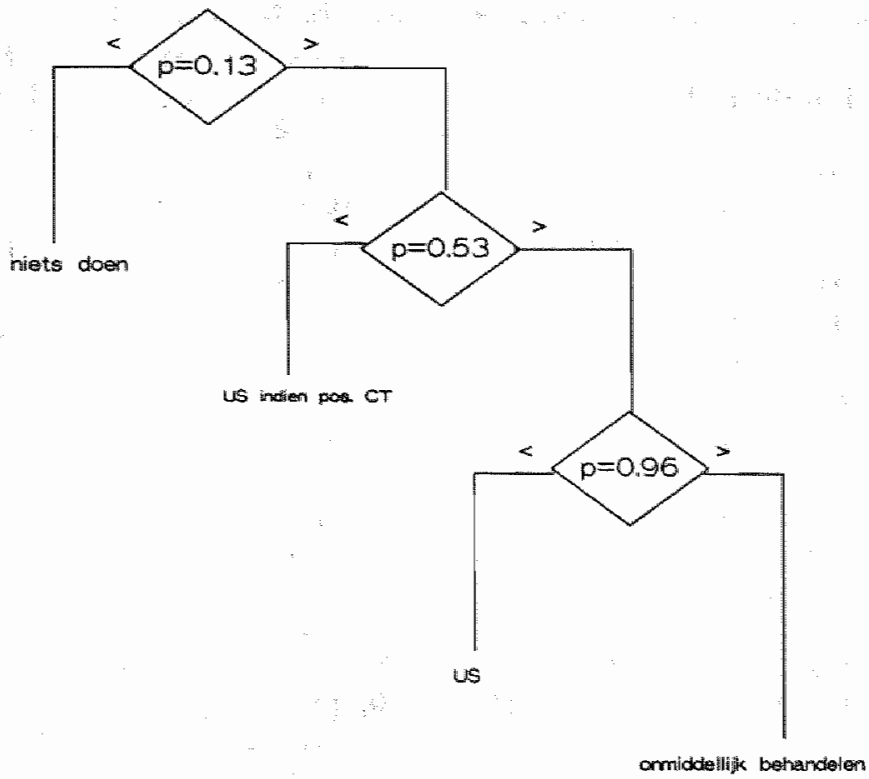

De vraag rijst welk protocol op dit moment in de medische praktijk wordt gehanteerd. In de ziekenhuissituatie waarop de kostengegevens betrekking hebben is er geen sprake van een expliciet protocol. In het Academisch Ziekenhuis Maastricht wordt er in geval van verdenking op metastasen van colonkanker bij lage a priori kansen $(p<.25)$ gebruik gemaakt wordt van US, terwijl bij hogere a priori kansen ( $\geq \geq .25$ ) de CT wordt toegepast. De redenering hierachter is dat de duurdere test alleen wordt toegepast, indien er een grotere kans bestaat op de ziekte.

Om de effecten te laten zien van de bovengenoemde protocollen kan voor verschillende p-waarden berekend worden wat de kosten en opbrengsten zijn. In onderstaande tabel zijn, voor kansintervallen van .1, de resultaten weergegeven in de vorm van kosten per QALY. 
Tabel 8.4. Kosten en opbrengsten bij drie protocollen

\begin{tabular}{cccc}
\hline kansinterval & $\begin{array}{c}(1) \\
0-K\end{array}$ & $\begin{array}{c}(2) \\
\text { K/O }\end{array}$ & $\begin{array}{c}(3) \\
\text { Praktijk }\end{array}$ \\
\hline $.01-.10$ & 0 & 0 & 48649 \\
$.11-.20$ & 9202 & 9202 & 13294 \\
$.21-.30$ & 8328 & 8288 & 10418 \\
$.31-.40$ & 7876 & 7818 & 9214 \\
$.41-.50$ & 7658 & 7549 & 8374 \\
$.51-.60$ & 7634 & 7321 & 7841 \\
$.61-.70$ & 7406 & 7049 & 7473 \\
$.71-.80$ & 7105 & 6845 & 7203 \\
$81-.90$ & 6865 & 6685 & 6997 \\
$.91-1.00$ & 6565 & 6504 & 6841 \\
\hline TOTAAL & 7602 & 7445 & 12689 \\
\hline TOTAAL KOSTEN & 260686 & 207460 & 297828 \\
TOTAAL OPBRENGSTEN & 368128 & 292888 & 374912 \\
\hline
\end{tabular}

Het protocol dat in de praktijk gehanteerd wordt heeft de hoogste $\mathrm{K} / \mathrm{O}$ ratio. Het protocol dat de $\mathrm{K} / \mathrm{O}$ minimaliseert heeft vanzelfsprekend de laagste $\mathrm{K} / \mathrm{O}$ ratio. Het O-K protocol benadert dit laatste protocol. Het praktijkprotocol blijkt met name bij lage en hoge waarden van $p$ inefficient, hetgeen geconcludeerd kan worden op grond van de kosten per QALY. Bij een lage p-waarde is zelfs een US te duur en bij hoge waarde van $\mathrm{p}$ geldt dit voor de CT. Wordt alleen gekeken naar het gemiddelde over alle kansen, dan blijken alle protocollen te leiden tot $\mathrm{K} / \mathrm{O}$ ratio's die lager zijn dan f 10.000 ,-

Handelen volgens het protocol $\mathrm{K} / \mathrm{O}$ leidt tot een extensief gebruik van middelen, een conclusie die ook híervóór reeds werd getrokken. De kosten bestaan overigens niet alleen uit testkosten maar ook uit behandelingskosten.

Welk protocol kan nu bestempeld worden tot het meest efficiënte protocol? Op deze vraag zal hieronder dieper worden ingegaan, waarbij de gegevens uit tabel 8.4 als referentiekader zullen worden gebruikt.

Wat in de praktijk tot de meest optimale oplossing gerekend moet worden kan nagegaan worden met behulp van de zogenaamde incrementele analyse, waarbij nagegaan wordt hoeveel extra kosten en opbrengsten duurdere protocollen met zich meebrengen ten opzichte van goedkopere protocollen (zie tabel 8.5).

Nemen we protocol 2, $(\mathrm{K} / \mathrm{O})$, als basis dan blijkt dat de totale incrementele kosten van protocol $1(\mathrm{O}-\mathrm{K})$ nog beneden de $f 10.000$,- liggen. Zou deze $f 10.000$,- de maximum 
Tabel 8.5. Incrementele kosten/incrementele opbrengsten bij drie protocollen

\begin{tabular}{lrrr}
\hline $\begin{array}{l}\text { kans- } \\
\text { interval }\end{array}$ & $(3)-(2)$ & $(1)-(2)$ & $(3)-(1)$ \\
\hline $.01-.10$ & 48858 & 0 & 48858 \\
$.11-.20$ & 46180 & 0 & 42637 \\
$.21-.30$ & 24157 & 9031 & 42727 \\
$.31-.40$ & 13556 & 8605 & 15200 \\
$.41-.50$ & 11520 & 8961 & 12396 \\
$.51-.60$ & 9376 & 8788 & 7500 \\
$.61-.70$ & 8614 & 8355 & -17414 \\
$.71-.80$ & 8168 & 7769 & 60 \\
$.81-.90$ & 8192 & 7466 & 1387 \\
$.91-1.00$ & 3216 & 7104 & -467 \\
\hline
\end{tabular}

waarde zijn voor een QALY, dan zouden beide protocollen dus in aanmerking komen. Beter is het echter om ook de incrementele analyse per $\mathrm{p}$-waarde (of per interval van $\mathrm{p}$-waarden) te analyseren. De incrementele $\mathrm{K} / \mathrm{O}$ verhouding van het protocol $\mathrm{O}-\mathrm{K}$ ten opzichte van het protocol $\mathrm{K} / \mathrm{O}$ zijn lager dan de maximumwaarde $(f 10.000,-)$ hetgeen bovenstaande conclusie nader onderstreept. $\mathrm{Nu}$ blijkt ook dat het praktijkprotocol relatief duur is ten opzichte van de beide andere protocollen. Bij p-waarden kleiner dan .5 resulteert dit in "dure" QALY's. Voor p-waarden groter dan .5 is er sprake van negatieve incrementele kosten, hetgeen wil zeggen dat een toename van kosten gepaard gaat met een daling in de opbrengsten, hetgeen de inferioriteit van het betreffende protocol illustreert.

Of er gebruik moet worden gemaakt van het $\mathrm{O}-\mathrm{K}$ of $\mathrm{K} / \mathrm{O}$ criterium hangt af van de situatie. Bekend is dat in bepaalde gevallen beide criteria tot eenzelfde beslissing leiden maar ook dat in andere situaties geen van beide criteria gebruikt kan worden. Indien het gaat om een beslissing over het al dan niet uitvoeren van een test (vergelijken van een strategie ten opzichte van een zogenaamde nul alternatief), kunnen beide criteria gebruikt worden (Drummond, 1980; Thompson, 1980). In de door ons te evalueren situatie is er sprake van wederzijds elkaar uitsluitende strategieën, waarbij het $\mathrm{O}-\mathrm{K}$ criterium gehanteerd kan worden (Thompson, 1980). Echter wanneer het er om gaat een bepaald budget zo optimaal mogelijk aan te wenden dan is volgens Thompson een $\mathrm{K} / \mathrm{O}$ criterium gewenst en waarschuwt Drummond dat vaak noch het $\mathrm{O}-\mathrm{K}$ noch het $\mathrm{K} / \mathrm{O}$ criterium gehanteerd kan worden. Voor Thompson ontstaat deze onduidelijkheid over het gebruik van beslisregels indien het situaties betreft waarbij de niet bestede budgetgelden terugvloeien naar de budgetverstrekker en aldus een alternatieve aanwending krijgen.

Bij de hantering van K/O ratio"s dient men er zich van bewust te zijn dat dergelijke ratio's zeer gevoelig zijn voor verkeerd definiëren van kosten en/of opbrengsten. Zo is 
het bijwoorbeeld in principe onjuist om "voorkomen gezondheidszorgkosten" als opbrengst aan te merken.

Van een dergelijke verkeerde definitie heeft de $\mathrm{O}-\mathrm{K}$ benadering geen last. Sommige auteurs gaan zo ver, dat ze stellen dat in het algemeen ratio's het best geheel kunnen worden vermeden en de economische evaluatie allén te baseren op $\mathrm{O}-\mathrm{K}$ versehillen (Feldstein, 1972, Blades e.a., 1987).

Uit het bovenstaande blijkt dat bij de diverse auteurs geen volledige owereenstemming bestaat ten aanzien van de toepassing van optimaliseringsregels. Een en ander blijkt afhankelijk te zijn van zekere randvoorwaarden. Hieronder zal nader aangegeven worden in hoeverre $e r$ in de onderhavige probleemsituatie voldaan is aan deze randwoorwaarden, teneinde in samenhang met bowenstaande theoretische bespiegelingen nadere uitspraken te kunnen doen welke beslisregel in de praktijk gehanteerd zou moeten worden.

Bij het kiezen van het juiste ewaluatiecriterium blijkt het van belang te zijn na te gaan of er sprake is wan

1. het bestaan van budgetrestricties,

2. opportunity kosten.

Daarnaast kan (on)deelbaarheid van projecten een rol spelen. Indien er binnen een gebudgetteerde omgeving gekozen moet worden tussen projecten, welke in hun geheel moeten worden uitgevoerd (ondeelbaarheid), dan bestaat de mogelijkheid dat er een bepaald restant van het budget niet toegedeeld kan worden aan projecten en dus ongebruikt blijft. Beide optimaliseringscriteria $\mathrm{O}-\mathrm{K}$ en $\mathrm{K} / \mathrm{O}$ kunnen dan leiden tot suboptimale oplossingen, omdat er wellicht combinaties van projecten zijn, die weliswaar inferieur scoren op genoemde criteria, maar in total een betere benutting inhouden van het beschikbaar budget, inclusief het restant (Thompson, 1980), De optimale allocatie kan in dergelijke gevallen gevonden worden met behulp van OR-technieken (Birch e.a. 1987).

In principe is er in het onderhavige geval weliswaar sprake van ondeelbaarheid (teststrategieen worden uitgewoerd of niet). Echter, het gewolg van een enkele diagnostische beslissing op het totale afdelingsbudget is dermate gering, dat ondeelbaarheid ten aamzien van diagnostische tests in de praktijk geen noemenswaardige belemmering vormt voor het bereiken van een optimale allocatie.

Hieronder zal respectievelijk ingegaan worden op de budgetrestrictie en de opportunity kosten.

Ter verduidelijking zall uitgegaan worden van het bestaan van een bepaald afdelingsbudget, waaruit ook de kosten van tests gefinancierd moeten worden. Indien de arts bij een bepaalde patient zich de vraag stelt wat de optimalle diagnostische handelwijze is dan zijn de volgende redeneringen mogelijk:

- Gaat de arts uit van de individuele patiênt en is het budget nog ruim voldoende dan zal hij geneigd zijn de $O-K$ regel toe te passen, waarbij de factor "kosten" wellicht nog een ondergeschikte rol speelt. Deze regel garandeert voor de betreffende patient de grootste winst in gezondheid.

- Naarmate de arts meer vanuit het besef van het bestaan van schaarse middelen handelt, zal hij meer geneigd zijn over te stappen naar de $\mathrm{O} / \mathrm{K}$ regel. Indien er nog maar een beperkt budget resteert, zal hij na moeten gaan bij welke inzet van de resterende middelen de meeste gezondheid wordt geproduceerd. De arts 
beperkt zich in dat geval tot het zo optimaal mogelijk besteden van zijn eigen budget (of dat van de afdeling).

Bovengenoemdle richtlijnen hebben tot gevolg dat de individuele arts min of meer gelijke patiënten in principe ongelijk behandelt.

Immers, wanneer er sprake is van een jaarbudget zou de arts aan het begin van het jaar waarschijnlijk duurdere teststrategieen volgen dan aan het eind van het jaar wanneer het budget op dreigt te raken. Dit wordt in de hand gewerkt door het feit dat de arts in principe niet weet hoeveel met patienten hij nog geconfronteerd wordt in de resterende tijd van de budgetperiode.

Een redenering, waarbij meer rekening wordt gehouden met het gelijkheidsbeginsel, houdt rekening met de opportunity kosten. Dit principe gaat ervan uit dat voor een optimale allocatie niet zozeer de reele kosten van het project van belang zijn, maar dat met name gekeken moet worden naar de potentiële opbrengst van de beste alternatieve aanwending. Deze niet gerealiseerde opbrengst van het beste alternatief is het offer dat gebracht wordt.

In het onderhavige voorbeeld worden de opportunity kosten vertegenwoordigd door de waarde van de QALY. Met behulp hiervan wordt de te behalen gezondheidswinst in monetaire eenheden uitgedrukt. Er wordt vanuit gegaan dat het behalen van gezondheidswinst de primaire doelstelling is binnen de gezondheidszorgsector. Deze waarde van een QALY kan in principe afgeleid worden uit het bestedingspatroon binnen de gezondheidszorgsector. Hoe hoger de waarde van een QALY, des te meer middelen zullen beschikbaar worden gesteld voor de gezondheidszorgsector. Aan de andere kant is het ook duidelijk dat naarmate er meer middelen beschikbaar worden gesteld de te behalen extra opbrengst geringer zal worden. Voor het produceren van extra eenheden QALY's is steeds meer geld nodig. Indien de productiefuncties exact bekend zouden zijn en de allocatie rationeel zou geschieden, zou de maximale waarde voor een QALY gelijk zijn aan deze grenswaarde, het laatst beschikbaar te stellen bedrag $\mathrm{X}$ waarvoor nog een QALY geproduceerd kan worden. Alle gezondheidszorg die duurder is, zal niet ten uitvoer gebracht worden, zolang er nog gezondheidszorgsectoren te onderscheiden zijn waar goedkopere QALY's kunnen worden geproduceerd.

Ondanks het feit dat uit de huidige praktijk van de gezondheidszorg deze waarde voor een QALY niet afgeleid kan worden, noch op andere wijze rechtstreeks bepaald kan worden, blijft theoretisch het uitgangspunt overeind. Er is een grenswaarde voor de QALY, alleen is, zelfs bij benadering, niet bekend waar deze grenswaarde in de huidige praktijk van het medisch handelen ligt.

Zolang er in bepaalde teststrategieën QALY's geproduceerd worden voor bedragen beneden de waarde van een QALY, is er in ieder geval sprake van een recell alternatief in die zin dat de oplossing valt binnen de grenzen van wat maatschappelijk aanvaardbaar wordt geacht.

Bij de bespreking van de uitkomsten van het rekenvoorbeeld uit dit hoofdstuk, is reeds verschillende malen geconstateerd, dat $\mathrm{K} / \mathrm{O}$ optimalisering leidt tot een geringere inzet van middelen dan optimalisering volgens O-K. Het verband tussen de beide vormen van optimalisering is nog exacter aan te geven. In de $\mathrm{O}-\mathrm{K}$ benadering wordt de opbrengst in QALY's gewaardeerd tegen een waarde gelijk aan de maximumwaarde voor een QALY (M). In de basisberekeningen is deze waarde gelijk aan $f 10.000,-$. Uit de K/O berekening blijkt dat voor bijna alle p-waarden QALY's worden geproduceerd tegen 
een lager bedrag dan deze genoemde $f$ 10.000,- (poor lage p-waarden is het bedrag per QALY groter dan $f 10.000$, , maar wordt automalisch de strategie niets doen gekozen). $\mathrm{Bij}$ een willekeurige a priori kans leidt het $\mathrm{K} / \mathrm{O}$ criterium tot het goedkoper produceren van QALY's dan het $\mathrm{O} K \mathrm{~K}$ criterium. Binnen de $\mathrm{K} / \mathrm{O}$ optimalisering wordt een volgorde van teststrategieen gecreëerd naar oplopende kosten per QALY en wordt vervolgens de goedkoopste strategie gekozen. Voor $\mathrm{p}=.9$ is dit bijwoorbeeld een strategie waarin QALY's geprodwceerd worden voor een bedrag van $f 6617,-$. Dit impliceert dat bij die p-waarden alle andere strategieen gekenmerkt worden door hogere kosten per QALY. Daarbij kunnen er strategieen zijn die duurder zijn dan de genoemde $f$ 6617,, , maar goedkoper dan $f 10.000_{5}^{-}$, maar bovendien kunnen er strategieên zijn waarin QALY's geproduceerd worden die duurder zijn dan $f 10.000,-$. De tweede groep strategieèn is in maatschappelijik opzicht onaanvaardbaar, gegeven dat $f 10.000$,- de maximumwaarde voor een $Q A L Y$ is. De strategieén uit de eerste groep zijn weliswaar duurder dan de meest kosten-effectieve strategie, maar well maatschappelijk aanvaardbaar.

Met behulp van de resultaten van het ontwikkelde programma kan de relatie tussen de $\mathrm{O}$-K en de $\mathrm{K} / \mathrm{O}$ benadering worden geillustreerd. Voor een bepaalde $\mathrm{p}$-waarde kunnen de optimale strategieèn worden bepaald volgens beide criteria en verwolgens kunnen voor diverse $M$-waarden de optimale strategieẽn volgens $\mathrm{O}-\mathrm{K}$ worden bepaald. In de volgende tabel is voor een aantal "interessante" $p$-waarden deze exercitie uitgevoerd.

In de $\mathrm{O}-\mathrm{K}$ benadering (basismodel) wordt de eenheid opbrengst gewaardeerd op $f$ 10,000,- (zie eerste regel tabel). In de $\mathrm{K} / \mathrm{O}$ benadering worden, afhankelijk van de $\mathrm{p}$ waarden, QALY's geproduceerd tegen $\pm f 7.000^{\text {- }}$ (laatste regel tabel). In de tussenliggende regels staan de optimale strategiee̊n, volgens het $\mathrm{O}-\mathrm{K}$ criterium, waarbij de waarde van $M$ varieert van $f 10.000$,- tot $f 7.000$, . Bij lagere $M$-waarden blijkt de 0 $\mathrm{K}$ benadering tot optimale strategieèn te leiden, welke gekenmerkt worden door lagere K/O verhoudingen dan de optimale strategieen bij het criterium O-K. Deze lagere $\mathrm{M}$ waarde blijkt aldus te functioneren als randvoorwaarde voor de optimale strategie. Uit de figuur blijkt duidelijk dat naarmate deze $M$-waarde de $\mathrm{K} / \mathrm{O}$ verhouding, van de optimale strategie volgens het $\mathrm{K} / \mathrm{O}$ criterium nadert, ook de optimale strategie volgens het $\mathrm{O}-\mathrm{K}$ criterium meer gelijkenis vertoont met de optimale strategie volgens het $\mathrm{K} / \mathrm{O}$ criterium. Met andere woorden, indien de optimale strategie bepaald wordt volgens het O.K criterium, waarbij de opbrengsten gewaardeerd worden tegen een bedrag, dat gelijk is aan de $\mathrm{K} / \mathrm{O}$ van de optimale strategie, leidt optimalisering volgens het $\mathrm{K} / \mathrm{O}$ criterium tot dezelfde oplossing als het $\mathrm{O}-\mathrm{K}$ criterium. $\mathrm{O}-\mathrm{K}$ berekeningen geven de maximale grens aan van toelaatbare oplossingen voor $\mathrm{K} / \mathrm{O}$ berekeningen.

We zullen dit hoofdstuk besluiten met de navolgende paradox.

Het invoeren van de gedachte dat gezondheidszorgprogramma's niet uitgevoerd moeten wordlen indien zij QALY's produceren voor bedragen groter dan een bepaalde maximumwaarde, kan er tevens toe bijdragen dat patiënten en artsen gaan claimen dat niet de goedkoopste gezondheidszorg (kosten/opbrengsten) ten uitvoer moet worden gebracht, maar gezondheidszorg die dichter bij het betreffende maximum ligt dan op grond van $\mathrm{K} / \mathrm{O}$ criterium wordt voorgeschreven. Dit impliceert tevens dat er naast de optimale strategie andere teststrategieèn verschijnen als mogelijk oplossingen waaruit dan een keuze zou gemaakt moeten worden. Een van de mogelijkheden is om die strategie te kiezen waarbij QALY's worden geproduceerd voor waarden die zo dicht 


\section{Tabel 8.6. Verband tussen optimalisering volgens criteria $\mathrm{O}-\mathrm{K}$ en $\mathrm{K} / \mathrm{O}$}

a) a priori kans $p=.40$

CRITIERI UM

OPTIMALE STRATEGIE BIJ P $=.40$

$k / 0$

a-K $M=f 10.000,-\quad$ us afk.pt. 4, indien pas. CT afk.pt. $3 f 7.730,-$ $M=f 9.000,-\quad$ US afk.pt. 3, indien pos. CT. afk.pt. $3 \quad f 7.67 B_{n}-$ $M=f 7.678,-$ us afk.pt. 3, indien pos. CT afk.pt. $3 \quad f 7.678,-$

$K / 0 M=f 7.678,-\quad$ US afk.pt. 3, indien pos. CT afk.pt. $3 \quad f 7.678,-$

b) a priori kans $p=.55$

\begin{tabular}{|c|c|c|c|}
\hline \multicolumn{2}{|c|}{ CRITERIUM } & \multirow{5}{*}{$\begin{array}{l}\text { OPTIMALE STRATEGIE BIJ } P=.55 \\
\text { CT afk.pt. } 2 \\
\text { US afk.pt. } 4 \text {, indien pos. CT afk.pt. } 3 \\
\text { US afk.pt. } 3 \text {, indien pos. CT afk.pt. } 3 \\
\text { US afk.pt. } 2\end{array}$} & \multirow{5}{*}{\begin{tabular}{l}
\multicolumn{1}{c}{$k 10$} \\
$7.654,-$ \\
$f 7.402,-$ \\
$f 7.378,-$ \\
$f 7.338,-$
\end{tabular}} \\
\hline $0-K$ & $M=f 10.000,-$ & & \\
\hline & $M=f 9.000 .-$ & & \\
\hline & $M=f 8.000,-$ & & \\
\hline & $M=f \quad 7.338,-$ & & \\
\hline k/o & $M=f 7.338_{0}-$ & US afk.pt. 2 & $f 7.338$. \\
\hline
\end{tabular}

c) a prior 4 kans $p=.70$

\begin{tabular}{|c|c|c|c|}
\hline \multicolumn{2}{|c|}{ CRITERI UM } & OPTIMALE STRATEGIE BIJP $=.70$ & $k / 0$ \\
\hline $0-K$ & $\begin{array}{l}M=f 10.000,- \\
M=f 9.000,- \\
M=f 8.000,- \\
M=f 6.947 .\end{array}$ & $\begin{array}{l}\text { US afk.pt. } 3 \text {, indien negl. CT afk.pt. } 3 \\
\text { US afk.pt. 2, indlen neg. CT afk.pt. } 1 \\
\text { US afk.pt. } 3 \\
\text { US afk.pt. } 2\end{array}$ & $\begin{array}{l}f 7.432,- \\
f 7.249 .- \\
f 6.989 .- \\
f 6.947 .-\end{array}$ \\
\hline $\mathrm{k} / \mathrm{O}$ & $M=f 6.947 .-$ & US afk.pt. 2 & $f 6.947,-$ \\
\hline
\end{tabular}


mogelijk liggen bij de maximumwaarde voor een QALY.

Het hanteren van deze maximumwaarde voor een QALY, bedoeld om relatief dure vormen uit het gezondheidszorgsysteem te weren, zou tevens een aanzuigende werking kunnen hebben op de vraag naar duurdere vormen van "lichte" technologieên.

Indien dit effect zich in de praktijk voordoet zal deze maximumwaarde, bepaald op grond van evaluaties van hoogwaardige technologische ingrepen, te hoog blijken te zijn en naar beneden bijgesteld dienen te worden op grond van claims van patiënten welke baat hebben van "lichte" technologießn. 

BUDGETING

\subsection{INLEIDING}

In eerdere hoofdstukken van dit boek is vastgesteld dat oorzaken van de groei in testgebruik zowel aan aanbodzijde als vraagzijde zijn gelegen. Kostenbeheersingsstrategieen met betrekking tot het gebruik van tests zijn tot nu toe weinig effectief geweest. Vanuit het laboratorium is sterk de nadruk gelegd op kostenbesparing, welke onder andere gerealiseerd kan worden door automatisering. Tests kunnen daardoor relatief goedkoop geproduceerd worden. Maar deze ontwikkeling, welke zich mel name in de zeventiger jaren heeft afgespeeld is onvoldoende vergezeld gegaan van maatregelen die ook het aanvraaggedrag van artsen beïnvloeden. In feite lijkt een verregaande automatisering van het laboratorium zelfs de aandacht voor een kritisch gebruik van dergelijke technologieên af te leiden. In hoofdstuk 3 is de conclusie getrokken dat er een combinatie van veranderingsstrategieen nodig is om artsen te bewegen tot het aampassen van hun aanvraaggedrag. Deze combinatie van strategieen zal aan de ene kant moeten bestaan uit een onderwijskundige strategie, waardoor artsen meer inzicht krijgen in de mogelijkheden en beperkingen van tests en aan de andere kant uit een strategie, waarvan voldoende prikkels uitgaan om het aanvraaggedrag te wijzigen.

In voorgaande hoofdstukken zijn methodes ontwikkeld waarmee optimale combinaties van tests kunnen worden bepaald en waarbij zowell met de kosten als met de opbrengsten rekening wordt gehouden. Toepassing van besliskundige technieken op medische problemen vindt reeds een aantal jaren plaats. Tot nu toe echter zijn deze pogingen in de praktijk niet erg succesvol gebleken. Vaak wordt het ontbreken van de economische prikkels als mede- oorzaak van dit mislukken gezien. Onder invloed van de budgettering van ziekenhuizen zullen artsen in toenemende mate met de financiele grenzen van hun handelen te maken krijgen. In dit hoofdstuk zal worden nagegaan wat de mogelijkheden en beperkingen zijn van technieken op het terrein van de medische besliskunde in ziekenhuizen, waarbij specifiek aandacht besteed zall worden aan de stimulering van kosten-effectief handelen.

In paragraaf 9.2 zal nader ingegaan worden op de medische besliskunde en zal nagegaan worden waar de kracht ligt van deze methodiek en waar de tekortkomingen. Vervolgens zullen in paragraaf 9.3 de ontwikkelingen op het terrein van interne budgettering worden besproken waarbij met name de invloed op het klinisch handellen nader zal worden uitgewerkt. In paragraaf 9.4 tenslotte zal worden nagegaan wat de praktische toepassingen van het ontwikkelde model voor de keuze van een optimale teststrategie zijn.

\subsection{MEDISCHE BESLISKUNDE}

\subsubsection{Inleiding}

Voor de bespreking van de mogelijkheden en de beperkingen van de medische besliskundige benadering is het nodig onderscheid te maken tussen de "prescriptieve" en "descriptieve" benadering binnen de besliskunde (Lusted, 1978; Pauker, 1982; Kassirer, 1982). 
In de descriptieve benadering gaat het erom inzicht te verwerven in thet actuele redeneringsproces van artsen en te doorgronden van welke strategieển zij gebruik maken om klinische problemen op te lossen. Met name vanuit de psychologie is er veel onderzoek in deze richting verricht en is de kennis over het probleemoplossend vermogen van artsen toegenomen.

Prescriptief onderzoek biedt de handvatten voor de besluitvorming in de praktijk. De prescriptieve benadering is normatief van aard en mondt uit in voorschriften hoe te handelen in yoorkomende situaties.

Prescriptief onderzoek heeft te maken met gestandaardiseerde formele processen. In deze aanpak vindt explicitering plaats van waarde-oordelen en uitgangspunten, welke ten grondslag liggen aan besliskundige processen. Deze explicitering bevordert de inzichtelijkheid van de te nemen beslissingen, waardoor beslissingen rationeler onderbouwd kunnen worden. De communicatie over beslissingen wordt hierdoor bevorderd, een aspect dat ook in de sfeer van de opleiding aangewend kan worden. De resultaten van prescriptieve analyses kunnen worden samengevat in de vorm van protocollen welke richting geven aan het handelen van artsen.

Samengevat zou kunnen worden gesteld dat via descriptief onderzoek wordt vastgesteld hoe artsen in de praktijk handelen terwijl prescriptief onderzoek aangeeft hoe artsen zouden moeten handelen. De problematiek van dit boek beweegt zich op dit laatste, normatieve, terrein. Ook in dit hoofdstuk zal met name gekeken worden naar de mogelijkheden en beperkingen van de "prescriptieve" besliskunde al zal bij de navolgende beschrijving ook de kritiek vanuit de "descriptieve" hoek worden betrokken.

\subsubsection{Medische besliskunde}

In de besliskundige aanpak wordt het besluitvormingsproces uiteengelegd in een aantal logische en overzichtelijke stappen, die éen voor é̂n kunnen worden geanalyseerd.

De besliskunde tracht het denkproces expliciet te maken. Hierdoor ontstaat de mogelijkheid beslissingen meer rationeel te onderbouwen en daardoor beter toetsbaar te maken.

De besliskundige benadering wordt vaak gesteld tegenover de intuitieve benadering, vaak clinical judgement, klinische ervaring of intuïtie genoemd. Om een complex probleem te kunnen benaderen via een besliskundige aanpak dient dit probleem gereduceerd te worden tot hoofdzaken. Hierin schuilt enerzijds de kracht van de methode, maar aan de andere kant ook in zekere zin de beperking. Vaak worden alleen die factoren, welke zich lenen voor kwantificering, in de analyse betrokken. Een te sterke reductie leidt verder tot een model, dat geen goede afspiegeling meer is van de werkelijkheid. Optimalisering van een dergelijk model levert vanzelfsprekend geen bruikbare informatie op voor de praktijk.

De kwantitatieve besliskundige benadering vereist dat een probleem helder en precies omschreven kan worden en dat waarschijnlijkheden en uitkomsten in maat en getal kunnen worden uitgedrukt. Alle mogelijke gebeurtenissen moeten van tevoren worden geïdentificeerd. De technieken uit de besliskunde zijn met name bruikbaar indien er sprake is van onzekerheid. Dit houdt in dat waarschijnlijkheden of kansen een belangrijke rol vervullen in de analyse. 
Inzicht in een complex probleem kan worden verhoogd door do onderdelen van het probleem apart te bestuderen. De scheiding van een medisch probleem in een diagnostisch en een therapeutisch aspect is hiervan een voorbeeld. Bij de uiteindelijke oplossing wordt gebruik gemaakt van de inzichten ontstaan uit de afzonderlijk analyse van de deelproblemen. Besliskundigen hanteren deze methodiek veelvuldig. Zij delen het probleem op in deelproblemen, die successiewelijk worden bestudeerd en waarvan vervolgens de componenten weer tot een geheel worden samengevoegd. Dix (1987) maakt zich op dit punt zorgen dat scheiding van diagnostiek en behandèling tot suboptimale beslissingen leidt, vanwege onderlinge afhankelijkheid. Zo bepaalt het vertrouwen in een behandeling onder andere het te hanteren afkappunt van de test. In het hierboven ontwikkelde model worden besliskundige techinieken juist toegepast om deze afhankelijkheid in de analyse te betrekken.

De besliskundige analyse valt uiteen in een aantal fasen. Hieronder zal een aparte uiteenzetting worden gewijd aan de navolgende fasen: structurering van het probleem, kansschattingen, waarderingsproblematiek, optimalisering en gevoeligheidsanalyse.

\section{Structurering van het probleem}

Voordat overgegaan kan worden tot het structureren van het probleem, dient eerst het probleem onderkend te worden. Deze fase, die in het beleidsproces bekend staat als de probleemidentificatie, wordt niet gerekend tot het domein van de besliskundige. Probleemidentificatie is meer een taak van de degene, die de uiteindelijke beslissingen neemt (de beslisser) dan van de besliskundige.

Door de besliskundige zal in eerste instantie structuur aangebracht moeten worden in het probleem. Een essentieel onderdeel hierbij is dat alle denkbare alternatieven worden geildentificeerd teneinde de mogelijke bewegingsvrijheid te bepalen van de beslisser.

Bij de analyse van medisch besliskundige problemen wordt deze structuur vaak neergelegd in een zogenaamde beslisboom.

Een vaak voorkomend probleem is dat een overgesimplificeerde structuur van het probleem als uitgangspunt van de analyse wordt gehanteerd. Dit kan het gevolg zijn van het weglaten van delen uit de structuur, welke bij nader inzien toch relevant zijn, maar ook kan de in ogenschouw genomen tijdshorizon, waarover de gevolgen zich uitstrekken, niet adequaat zijn (Politser, 1982 en Young \& Poses, 1984).

\section{Kansschattingen}

Indien het probleem probabilistisch van aard is moeten de respectievelijke kansen worden bepaald. De medische literatuur verschaft vaak onvoldoende informatie om de kansen woor een specifiek ziektegeval rechtstreeks te bepalen. Derhalve zullen er aanpassingen moeten plaatsvinden voor het individuele geval. Hierbij dient bedacht te worden dat artsen slechts gevraagd wordt formeel te expliciteren wat zich anders impliciet in het beslissingsproces voltrekt. Het ontbreken van data is overigens niet een probleem dat specifiek is voor de medische besliskunde. Het bestaat ook in de meer intuïtieve benadering, maar blijft daar meestal onopgemerkt (Pauker \& Kassirer, 1987). Het schatten van waarschijnlijkheden met betrekking tot het voorkomen van ziekten is een vorm van explicitering. Zonder deze explicitering maken artsen gebruik van 
omschrijvingen als "frequent", "warschijnlijk", "mogelijk", etc begrippen waarvan bekend is dat lang niet ledereen hier hetzelfde onder verstaat (Kong e.a, 1986).

In het gehele diagnostische en therapeutische traject is er op vele momenten sprake van kansschattingen door artsen. In de eerste plaats zal de arts de a priori kans moeten inschatten, vervolgens zal hij de sensitiviteit en specificiteil van de test moeten kennen, hetgeen vaak ook neerkomt op schatten. Tenslotte zal ook de therapeutische winst vam de behandeling moeten worden geschat. Wordt de kwaliteit van leven met behulp van de $S G$-methode bepaald, dan komen er opnieuw kansschattingen aan te pas. Hieronder zal ingegaan worden op een aantal problemen met betrekking tot kansschatting van a priori kansen, sensitiviteil en specificiteit van tests en utiliteifen.

\section{A priarl kans}

Bij het schatten van deze kans doet zich een groot aantal problemen voor. In de cerste plaats ontbeert de arts waak een referentiekader. In de dagelijkse praktijk heeft de arts niet veel anders dan het wertrouwen in zijn eigen vermogen een dergelijke kans te schatten. De gepubliceerde prevalenties van ziekten in de bevolking zijn niet zonder meer toepasbaar op de groep patienten in het ziekenhuis. De samenstelling van deze groep patienten wordt mede beinvloed door de wijze van selecteren in de eerste lijn. Verder is de a priori kans van de individuele patiënt afhankelijk van de specifieke combinatie van symptomen van die patient. Kennis van de invloed van combinaties van symptomen op de kans op ziekte is dan ook onontbeerlijk voor de arts.

De arts zal de a priori kansinschatting (voor de test) mede moeten baseren op deze prevalentiegegevens. Indien hij deze laatste cijfers overschat of onderschat, zal dientengevolge ook de a priori kans worden over- c.q. onderschat (base rate bias).

Aangezien artsen hun schattingen mede baseren op het vermogen om zich gelijksoortige patiënten te herinneren, kan een recente confrontatie met een dergelijke patiënt gemakkelijk aanleiding geven tot overschatting van de betreffende a priori kans. Ook indien de arts de ziekte als zeer ernstig beschouwt, zal er een neiging bestaan tot overschatting van de a priori kans (value induced bias).

Dat de arts in lang niet alle gevallen in staat is een adequate inschatting van de a priori kans te geven, hoeft na het bovenstaande geen betoog (Young \& Poses, 1984). De resultaten uit onderzoek zijn niet altijd gelijkluidend. Bij een ander experiment is een groep artsen gevraagd a priori kansen te schatten voor een zevental verschillende probleemsituaties. De "kleinste" variatie vertoont een range van $2 \%$ tot $82 \%$ ! Ook is de gemiddelde standaardafwijking erg hoog: bijna $20 \%$ (Dolan e.a., 1986).

Er zijn cehter ook onderzoeken waaruit het tegenovergestelde blijkt. Tierny e.a. (1986) vonden dat een groep cardiologen goed in staat was op grond van anamnese en lichamelijk onderzoek de kans op aanwezigheid van een myocardinfarct te voorspellen. Het voornaamste verschil met bovenstaand onderzoek is dat in dit laatste onderzoek een groep artsen is betrokken, die frequent met de betreffende patiënten te maken heeft. In het eerstgenoemde onderzoek bestaat er in de onderzoeksgroep verschil naar opleidingsniveau, maar bovendien is door de diversiteit in de casuistiek veel minder specifieke ervaring opgebouwd met betrekking tot de gepresenteerde ziektegevallen.

Bij nadere vergelijking van diverse onderzoeksresultaten blijken nog meer verschillen. Zo blijkt uit een bepaald onderzoek dat ervaren artsen beter in staat zijn deze kansen 
in te schatten dan jonge artsen (Shapiro, 1977). Dit fenomeen is niet bevestigd in het reeds aangehaalde onderzoek van Dolan e.a. (1986).

De mate waarin artsen in staat zijn a priori kansen adequaat in te schatten bepaalt grotendeels de bruikbaarheid van de tests.

Een dergelijke schatting kan intuitief geschieden, maar kan ook gebaseerd zijn op formele rekenprocedures, zoals de regel van Bayes. Experimenteel kan worden aangetoond dat de werking van de regel van Bayes niet of nauwelijks intuitief kan worden aangevoeld. Zo toonde Casscells e.a. (1978) aan dat slechts $18 \%$ van een groep artsen het correcte antwoord wist te formuleren op een eenwoudig probleem waarbij gevraagd is, de a posteriori kans te schatten op basis van a priori informatie. Meer recent is dit experiment herhaald (Billings \& Bernstein, 1985). Zij komen tot 33\% correcte antwoorden.

Bij een intuïtieve benadering blijkt de invloed van tests op de waarschijnlijkheid van voorkomen van ziekten, niet op de juiste wijze te worden ingeschat, hetgeen op zichzelf een pleidooi inhoudt voor de meer expliciete, formele benadering.

\section{Sensitiviteit en specificiteit}

Van een andere orde zijn de problemen die gepaard gaan met het schatten van kansen zoals sensitiviteit en specificiteit. Deze kansen behoeven niet door de artsen geschat te worden, maar moeten worden bepaald door middel van onderzoek. Het blijkt dat de sensitiviteit en specificiteit lang niet altijd bekend zijn.

Bij de bepaling van de sensitiviteit en specificiteit van een test kunnen diverse fouten gemaakt worden. De fouten kunnen veroorzaakt worden door: (1) de aard van het patiëntenbestand dat gebruikt wordt als onderzoeksgroep (spectrum bias) en (2) mogelijke vertekeningen zowel met betrekking tot de testuitslag als met betrekking tot de ziektetoestand (Ransohoff en Feinstein, 1978).

Bij de bepaling van de sensitiviteit dient gelet te worden op pathologische (bijvoorbeeld locatie, cel-type etc.) en klinische (zoals ernst van symptomen, duur etc.) kenmerken van patiënten. In principe geldt de betreffende sensitiviteit en specificiteit slechts voor die groep patiënten, welke gekenmerkt wordt door een identiek spectrum van de ziekte. In vele gevallen is onvoldoende bekend, of zelfs volstrekt onbekend, op welke onderzoeksgroep gepubliceerde sensitiviteit en specificiteit betrekking hebben.

Een tweede fundamenteel probleem bij de bepaling van sensitiviteit en specificiteit betreft de gouden standaard problematiek. Zo dient de ziektetoestand in principe te worden vastgesteld onafhankelijk van de testuitslag. Ook dit ideaal is in de onderzoekspraktijk niet altijd haalbaar. Fouten van verschillende oorsprong kunnen genoemd worden:

- work-up bias:

in sommige omstandigheden bepaalt de testuitslag de daar op volgendle klinische work-up en beinvloedt op deze wijze de diagnosestelling.

- diagnostic review bias: deze ontstaat indien een subjectieve beoordeling van de diagnostische gegevens mede de diagnosestelling beinvloedt.

- test review bias: deze ontstaat wanneer de testuitslag mede wordt bepaald aan de hand van de diagnosestelling. 
Naast bovengenoemde fouten zijn er nog andere mogelijke bronnen van fouten te vermelden.

Zo worden testuitslagen welke moeilijk zijn te interpreteren meestal weggelaten uit de analyse. Dit leidt niet alleen tot problemen bij de vaststelling van testkarakteristieken, maar ook tot extra kosten. Tests met onduidelijke testuitslagen moeten opnieuw aangevraagd worden (Begg, 1987). Tenslotte kunnen ook door technologische veranderingen de sensitiviteit en specificiteit van tests beïnvloed worden.

Harris (1981) ging voor zeven bekende tests na in hoeverre gegevens beschikbaar waren over sensitiviteit en specificiteit. Bij twee tests bleken deze gegevens redelijk vast te staan, bij vijf werd een grote variatie in de uitkomsten geconstateerd. Als oorzaken van deze grote verschillen signaleerde hij problemen waarbij de reproduceerbaarheid en de inter-waarnemers variabiliteit in het geding zijn.

Het spreekt vanzelf dat het ontbreken van betrouwbare schattingen van sensitiviteit en specificiteit een ernstige belemmering vormt voor de toepassing van de besliskundige benadering in de praktijk.

\section{Utlliteiten}

Nadat de uitkomsten bepaald zijn, moeten er waarderingen gehecht worden aan de uitkomsten. Daarbij komt het probleem, dat men moet bepalen welke utiliteiten men gebruikt, die van de arts, die van de patient of die van de maatschappij (McNeil \& Pauker, 1982).

De keuze hangt sterk af van de context waarbinnen de resultaten van de analyses gebruikt gaan worden. Worden de uitkomsten van de analyses gebruikt voor het bepalen van de beste strategie voor de individuele patiënt, dan zullen de utiliteiten van de patiënt van belang zijn. Worden ook de financiële grenzen expliciet in de beslissingen betrokken, dan wordt het individuele belang overstegen en dienen groepsbelangen bij de besluitvorming te worden betrokken.

Methoden om utiliteiten te bepalen zijn beschikbaar. In een recent overzicht is de stand van zaken vermeld met betrekking tot het meten van utiliteiten van gezondheidssituaties ten behoeve van economische evaluatie (Torrance, 1986). Veel gebruikte utiliteitsanalyses zijn: de Standard Gamble, de Time Trade Off en de Visual Analoge methodiek. Uit het literatuuroverzicht blijkt de interne betrouwbaarheid van deze drie methodieken, dat wil zeggen de mate van overeenstemming binnen eenzelfde interview, hoog te zijn $(0,86<\mathrm{r}<0,94)$, waarbij $\mathrm{r}$ gelijk is aan product moment correlatie coefficieient.

De test-retest betrouwbaarheid lijkt redelijk, zolang de tussenliggende periode beperkt blijft tot een aantal weken $(0,63<\mathrm{r}<0,80)$. Na een jaar blijkt deze betrouwbaarheid lager te zijn $(r= \pm 0,5)$ hetgeen overigens gedeeltelijk een reflexie kan zijn van de zich wijzigende preferenties in de tijd.

De spreiding in de individuele scores is groot. De spreiding kan niet verklaard worden op grond wan factoren als leeftijd, geslacht, beroep etc. Uit onderzoek is gebleken dat deze spreiding kleiner is in homogene groepen, die geacht worden een goed inzicht te hebben in de gevolgen van de ziekten. Utiliteitsbepaling bij patiënten blijkt een geringere spreiding op te leveren in utiliteitsscores dan bij representanten van de gezonde bevolking het geval is. 
Vergeleken met de Standard Gamble is de Time Trade Off methodiek valide te noemen, terwijl de Visual Analog niet valide is.

In een Nederlands onderzoek konden bovenstaande conclusies worden onderschreven. Overigens werden in dit laatst genoemde onderzoek de utiliteiten ook bepaald via een speciaal daartoe ontwikkeld interactief computerprogramma. De betrouwbaarheid bleek in dit laatste geval hoger dan het geval was bij utiliteitsbepaling via een schriftelijke methodiek (Ament e.a., 1986).

Ten aanzien van methoden om gezondheidssituaties te meten kan het volgende geconcludeerd worden: Utiliteitsmetingen ten behoeve van economische evaluatie zijn mogelijk, al moet daarbij cen zekere mate van onnauwkeurigheid geaccepteerd worden. Gevoeligheidsanalyses kunnen duidelijk maken wanneer een nader onderzoek naar utiliteiten gewenst is. Soms kan volstaan worden met globale schattingen en steeds vaker kan gebruik gemaakt worden van reeds gepubliceerde utiliteiten met betrekking tot diverse gezondheidssituaties.

Resultaten van utiliteitsbepalingen worden reeds toegepast in kosteneffectiviteitsanalyses ten behoeve van de planning van hoogwaardige technologieen, zoals open-hartchirurgie, nierdialyses, etc. Voordat dergelijke utiliteitsanalyses met succes kunnen worden toegepast in de sfeer van de besluitvorming met betrekking tot individuele patiënten, zal nader onderzoek naar de validiteit en betrouwbaarheid van het meetinstrument uitgevoerd moeten worden. Of artsen en/of patiënten dergelijke methoden in de praktijk zullen accepteren hangt onder andere af van deze nadere onderzoeken (Wulff, 1980).

\section{Optimaliseren}

In de optimaliseringsfase wordt de beste strategie bepaald gegeven de drie voorgaande fasen.

In de meeste gevallen wordt hierbij uitgegaan van het verwachtingswaarde-model (expected value model), zie bijwoorbeeld Thompson (1982). In deze benadering worden de diverse uitkomsten gewogen met de kansen van optreden. Het is echter nog maar de vraag of beslissingen, gebaseerd op een dergelijk uitgangspunt, welke voor cen groep patiënten de beste strategie oplevert, ook voor de individuele patient de meest gunstige strategie is. Aan het hier gesignaleerde probleem is een tweetal belangrijke aspecten te onderscheiden: een ethisch en een meer technisch aspect, dat met de risicogeneigdheid van de arts of patiènt te maken heeft.

De besliskundige bemadering is een representant van wat in de normatieve ethica bekend staat als utilitaristisch hamdelen (Wulf, 1980). Het uitgangspunt wan het utilitarisme is dat op grond van de gevolgen van handelingen beoordeeld kan worden of de betreffende handeling leidt tot een toename van geluk. Binnen het utillitarisme zijn twee richtingen te onderscheiden. Het act-utilitarisme dat het grootst mogelijk geluk voor iedereen, die de gevolgen van de handeling ondergaat, nastreeft. Het regelutilitarisme hanteert bij de keuze twee stappen: eerst worden de regels vastgesteld, waarna de effecten bepaald worden die de verschillende regels hebben op het geluk van de betrokkenen. De verschillen lijken niet groot omdat in beide benaderingen "het grootste geluk voor het grootste aantal" wordt nagestreefd, maar in de geneeskunde heeft het act-utilitarisme met name betrekking op de problematiek van individuele patiënten, terwijl regel-utilitaristisch handelen meer gericht is op het groeps- c.q. 
maatschappelijk belang. Het rekening houden met de kostengevolgen van de beslissing is een vorm van regel-utilitaristisch handelen. Bij patientgericht utilitarisme is er eerder sprake van maximalisering van de opbrengsten.

Het tweede aspeet, dat hierbij cen rol speelt, betreft de zogenaamde risicogeneigdheid van de uiteindelifke beslisser.

Bepaalde aspecten in deze risicogeneigdheid, bijvoorbeeld de risicogeneigdheid ten aanzien van overlevingsjaren, kunnen worden geintegreerd in de utiliteitsscores, zeker indien deze bepaald worden door de Standard Gamble methodiek. Maar dit impliceert niet zonder meer dat dan op adequate wijze met alle vormen van risicogeneigdheid rekening is gehouden. De verwachtingswaarde is niet altijd het juiste richtsnoer voor optimalisering. Men zal zjn toevlucht dan zoeken tot alternatieven, zoals bijvoorbeeld mini-max strategieen, waarbij er naar gestreefd wordt om de grootste negatieve gevolgen zo gering mogelijk te houden.

\section{Gevoeligheldsanalyse}

Dit is een zeer belangrijke fase, omdat hier de robuustheid van de optimale oplossing onderzocht wordt. In hoeverre kunnen bepaalde variabelen veranderen zonder dat de optimale strategie verandert? In de gevoeligheidsanalyse komt in ieder geval vast te staan welke gegevens van grote importantie zijn en welke niet. Het resultaat van een gevoeligheidsanalyse kan ofwel zijn dat vervolgonderzoek niet nodig is (de gegevensverzameling is voldoende om adequate oplossingen te kunnen formuleren voor het probleem) ofwel dat nauwkeuriger wordt aangegeven welk vervolgonderzoek nodig is om de specifieke informatie te verkrijgen die voor de oplossing van het betreffende probleem nodig is.

Een dergelijke aanvullende analyse is vooral van belang, indien er in het model gegevens worden gebruikt welke in hoge mate onbetrouwbaar zijn. Vaak wordt nagelaten een gevoeligheidsanalyse te verrichten met betrekking tot de gekozen structuur van het probleem (Weinstein, 1981).

\section{2,3. Besliskunde in de medische praktijk}

In de afgelopen decennia is er een grote stroom publicaties op gang gekomen met betrekking tot het onderwerp medische besliskunde. De methodologie is verder ontwikkeld en talloze toepassingen van besliskundige analyses zijn gepubliceerd. Toch bestaat niet de indruk dat dit alles van grote invoed is geweest op het beslissingsproces van de arts in de dagelijkse praktijk. De vraag rijst of artsen in de praktijk met behulp wan besliskundige technieken betere beslissingen nemen dan zonder. Een interessante vraag is verder, indien deze eerste vraag met ja beantwoord zou worden, waarom artsen tot nu toe zo weinig gebruilk maken van deze "nieuwe" technologie. Een aantal met dit probleem samenhangende factoren zal in deze paragraaf besproken worden, waarbij met mame de medische kant van de besliskunde belicht wordt. De economische kant ervan wordt in de volgende paragraaf besproken.

In hoofdstuk 3 is reeds aangegeven dat er een grote variatiebreedte bestaat in de wijze waarop artsen gebruik maken van tests. Dit geldt ook binnen andere delen van de gezondheidszorg (Begley, 1986). Verbetering van de zorg uitgaande van dezelfde middelen of het leveren van dezelfde gezondheid tegen een lager kostenniveau lijkt op grond hiervan in principe haalbaar. 
Het is goed om na te gaan welke rol de medische besliskunde in deze zou kunnen spelen. Kan yoldaan worden aan de hooggespannen verwachtingen die velen hebben ten aanzien van de medische besliskunde? $\mathrm{De}$ introductie van besliskunde in het medisch curriculum kan tot een verandering in de attitude van de arts leiden. Acceptatie van risico's welke inherent zijn aan het medisch handelen, zou het ongefundeerde vertrouwen in de technologie kunnen verminderen en daardoor ook de invloed van het "technologisch imperatief" (Lawrence, 1980).

De stelling dat de arts in de praktijk met behulp van medische besliskundige technieken tot betere beslissingen komt, is moeilijk te bewijzen (Cebul, 1984).

Wel is het mogelijk aan te geven op welke gebieden en in welke opzichten de besliskundige benadering voordelen biedt boven de traditionele medische aanpak. Op een aantal aspecten zal hieronder nader worden ingegaan.

De bijdrage van de besliskundige analyses is meer relevant woor onderdelen van de totale analyse dan voor het totall van de besluitvorming (Young, 1984). Dit sluit aan bij de opvatting van mamagers in het bedrijfsleven dat besliskundige analyses minder worden toegepast bij complexe problemen en meer ingeschakeld worden bij het optimaliseren van deelproblematiek (Ransohoff \& Feinsteiln, 1976).

Ook het argument dat besliskunde het aureool van de klinische blik demystificeert en reduceert tot een ordinaire beslisboom houdt bij nader inzien geen stand. Besliskundige analyses kunnen het beste uitgevoerd worden door ervaren artsen die met hun klinische blik hoofd- en bijzaken van elkaar weten te scheiden. Ook in een besliskundige benadering blijft zeer veel ruimte over voor de intuittieve benadering. Met name ervaren artsen kunnen de besliskundige analyses zien alls aanvulling op het eigen besliskundig proces (Gorry, 1978).

Medische beslissingen blijven uiteindelijk mede gebaseerd op intuittie. Het eigenlijke doel van besliskunde is volgens sommigen niet zozeer het vervangen van de rol van intuitie, maar louter en alleen het verbeteren van de accuraatheid van de communicatie betreffende de intuitie (Dix 1987 ). Ook het eerder geciteerde onderzoek van Kong e.a. (1986) wijst op het gebrek aan overeenstemming bij het hanteren van kwalitatieve uitspraken, hetgeen een belemmering vormt in het communicatieproces.

Medische besliskunde maakt het de arts mogelijk om het eigen handelen met dat van zijn collega's te vergelijken. Bij afwijkende beslissingen kan de oorsprong van de verschillen worden opgespoord. Is het een verschil in waardering, is het een afwijkende kansinschatting of is het risicogedrag wellicht verschillend, etc.?

Ook Pauker \& Kassirer, voorstanders van de besliskundige benadering, zijn van mening dat de waarde van deze benadering onder andere gezocht moet worden in de bijdrage tot het communicatieproces van artsen onderling (Pauker \& Kassirer, 1987).

De toepasbaarheid van besliskundige technieken in de praktijk wordt sterk belemmerd doordat lang niet altijd voldoende tijd beschikbaar is voor een gedegen analyse (Schwartz, 1979). Veel analyses vergen inderdaad veel tijd, maar vaak kan ook met een eenvoudige analyse meer inzicht verworven worden dan zonder een dergelijke analyse. Gecompliceerde gevallen, die zeer veel tijd vergen, komen minder frequent voor. Door het opzetten van databanken kan veel tijdwinst geboekt worden bij het verzamelen van de benodigde gegevens. Verder is er in de loop der tijd steeds meer programmatuur 
beschikbaar gekomen om besilisproblemen inclusief gevoeligheidsanalyses door te rekenen en om utiliteiten te bepalen.

Toch is de besliskundige benadering met betrekking tot het tijdsaspect altijd in het nadeel ten opzichte wan de intuitieve benadering. Een mogelijkheid om het tijdsprobleem te omzeilen is om anticiperend op te treden en de resultaten van besliskundige analyses te verwerken in of op te nemen in de vorm van protocollen. Protocollen kunnen in de medische praktijk een belangrijke ondersteuning en houvast bieden bij het besliskundig handelen.

De eventuele angst dat protocollen de arts overbodig zullen maken is volledig ongegrond, Zo is het bijvoorbeeld uitgesloten dat er standaard diagnostische protocollen zouden kunnen worden opgesteld voor alle typen patienten.

Om via 20,000 mogelijke symptomen te komen tot een differentiaal diagnose $( \pm 40,000$ mogelijkheden) is een kunst die voorlopig alleen aan artsen is voorbehouden (Gross, 1985).

Uit het bovenstaande kan geconeludeerd worden dat de medische besliskunde een bijdrage kan leveren aan het besliskundige proces van artsen. De vraag is waarom er tot nu toe zo weinig gebruik gemaakt wordt wan deze techniek in de praktijk.

Indien de angst voor de besliskunde als een nieuwe technologie grotendeels ongegrond is en de voordelen langzamerhand steeds meer erkend worden, dan resteert de vraag hoe ervoor gezorgd kan worden dat deze technologie zich in de medische wereld cen plaats verovert die hem toekomt.

De ervaring van Pauker met medische besliskunde in het New England Medical Center is in dit kader vermeldenswaardig. De aanvankelijke pogingen om de medische besliskunde ingang te doen vinden in het betreffende ziekenhuis leden schipbreuk. Toen men echter vanuit het Department Clinical Decision Making Consultation Service te Boston, dat adviezen verstrekt over medisch-besliskundige problemen, deze pogingen staakte, is gebleken dat een groot aantal artsen in staat is deze technieken toe te passen in hun eigen patiëntenpopulatie. Daarbij blijkt overigens wel dat de animo toeneemt indien vanuit het centrum hulp wordt verleend bij het analytische werk en bij het maken van de noodzakelijke berekeningen. Voor de invoering van deze technieken is het niet absoluut vereist dat de arts, die dergelijke methoden in de praktijk hanteert, zich ook de onderliggende wiskundige en statistische inzichten volledig eigen maakt (Gorry, 1978). In paragraaf 9.4 zal nader ingegaan worden op de toepasbaarheid van de hiervoor ontwikkelde besliskundige instrumenten in de medische praktijk.

Het ontbreken van de juiste incentives in het verleden wordt door sommigen als belangrijkste reden gezien voor het feit dat besliskundige technieken zo weinig ingang hebben gevonden (Komaroff ea., 1982; Sox, 1987).

Op dit punt zijn er echter de laatste jaren fundamentele veranderingen opgetreden en het lijkt erop dat bijvoorbeeld in de Nederlandse gezondheidszorg, de voorwaarden voor invoeren van besliskundige technieken zijn verbeterd.

In de volgende paragraaf zal op deze ontwikkelingen worden ingegaan. 


\subsubsection{Inlelding}

Vanaf 1983 is in Nederland een budgetteringssysteem in de ziekenhuizen ingevoerd. Voorheen zijn de ziekenhuizen gefinancierd door middel van vergoedingen voor bepaalde prestaties zoals verpleegdagen, verrichtingen, ete. Naarmate het ziekenhuis in een dergelijke situatie meer produceert nemen de beschikbare financiele middelen toe. Vooral in afdelingen, zoals laboratoria, heeft de noodzaak ontbroken om minder te produceren. Ondanks het feit dat de vergoedingen voor verrichtingen in het algemeen lager zijn dan de gemiddelde kosten, is uitbreiding van de productie aantrekkelijk, omdat de vergoeding hoger was dan de marginale kosten. Mét de invoering van de budgetteringssystematiek is deze ongewenste incentive-structuur verdwenen en vervangen door een systeem waarbij aan het ziekenhuis budgetten verstrekt worden, waarvan de hoogte wordt bepaald met behulp van een aantal parameters. De invoering van het budgetteringssysteem heeft ongetwijfeld grote invloed gehad op de kostenontwikkeling binnen de intramurale gezondheidszorg.

De instellingen, geconfronteerd met externe budgetten, hebben behoefte gekregen aan ontwikkeling vam interne budgetteringsmechanismen teneinde ervoor te zorgen dat de productie afgestemd werd op de beschikbare (externe) financiële ruimte. Een apart probleem hierbij wordt gevormd door de positie van de medische professie binnen de ziekenhuisorganisatie. De medische beroepsgroep bewaakt van oudsher zorgvuldig de professionelle autonomie, mar het is vrijwel onafwendbaar dat de invoering van budgettering leidt tot een verdere inperking van deze autonomie: Met andere woorden de invoering van de budgettering maakt de financiele randvoorwaarden van de autonomie zichtbaar. Door de invoering van de budgettering is in Nederland een nieuwe situatie ontstaan. In het buitenland, met name daar waar het gezondheidszorgsysteem woor een belangrijk deel collectief gefinancierd wordt, bestaat reeds langer ervaring met budgettering. De National Health Service in Engeland en het Zweedse gezondheidszorgsysteem vormen voorbeelden hiervan. Ook binnen deze gezondheidszorgsystemen bleek de professie maar moeilijk te kunnen wennen aan het bestaan van financiele gremzen. Hieronder zal ingegaan worden op de specifieke positie van de professie in een gebudgetteerde omgeving (par. 9.3.2) en zal de invloed van budgettering op het gedrag van artsen worden besproken (par. 9.3.3).

\subsubsection{Budgettering en de professie}

De enige jaren geleden geintroduceerde budgetteringssystematiek van ziekenhuizen heeft op vele terreinen diepe sporen nagelaten (Van der Eyden, 1987). In de eerste plaats lijkt het erop dat deze budgettering de kostenontwikkeling ingetoomd heeft. In zijn inaugurele rede is Maarse onlangs onder andere ingegaan op het mogelijke verband tussen de invoering van budgettering en de ontwikkeling van productie en kosten in ziekenhuizen (Maarse, 1988). Hoewel hij voorzichtigheidshalve de nodige kanttekeningen plaatst bij de door hem gehanteerde methode concludeert hij, dat invoering van de budgettering ertoe heeft bijgedragen dat onder andere het aantal opnamen is afgenomen en het aantal verpleegdagen versneld is gedaald. Merkwaardig genoeg is deze invloed niet zonder meer terug te vinden in het gebruik van klinische en poliklinische verrichtingen (zie ook hoofdstuk 2). 
Vergelijking van hel financieringssysteem, dat woorheen heef gevigeerd (outputfinanciering), en de huidige budgetformule maakt duidelijk dat de relatie tussen het management en de professie fundamenteel is gewijzigd. Hebben de belangen voorheen parallel gelopen (productiemaximalisatie), momenteel zijn deze belangen min of meer tegengesteld, althans wat de financieel-economische aspecten van de zorgverlening betreft. In de praktijk betekent dit dat vroeger door het management tegemoet gekomen is aan vele wensen van de professie. Deze traditionele organisatievorm van hel ziekenhuis, door Mintzberg (1979) professionele bureaucratie genoemd, steat echter op gespannen voet met de situatie van interne budgettering.

Sinds de invoering van de budgettering is de positie van de professie aan een heroverweging toe.

Het management en de professie zullen binnen een gebudgetteerde omgeving gezamenlijk het beleid moeten uitstippelen. Voor de betrokkenheid van de professie bij het management, en in engere zin bij budgettering, zijn zelfs ethische motieven aan te voeren. Alleen door die betrokkenheid kan de professie garant staan woor optimale zorg voor de patiènten (Wickings \& Colle, 1984).

Een mogelijkheld om de scherpe tegenstellingen tussen de medische en economische benaderingen te verzachten is het betrekken van artsen bij het nemen van beslissingen op organisatieniveau, bij de middelenallocatie, bij capital budgeting, bij goalsetting en de strategische planning (Winkenwerder \& Ball, 1988). Voor Fowkes (1985) is het verantwoordelijk maken van de professie voor het besteden van de klinische budgetten op lange termijn de beste strategie om een efficient gebruik van tests te bewerkstelligen.

Ook binnen de Nederlandse gezondheidszorg zal een oplossing gewonden moeten worden voor het probleem van de professionele autonomie aan de ene kant en de financiele grenzen aan de andere kant.

Specialismen zijn te onderscheiden in: poortspecialismen en de ondersteunende specialismen, welke diensten verlenen op verzoek van de poortspecialisten (Schaaf, 1984). Dit onderscheid is essentieel in het kader van het ontwerpen van een budgetteringssysteem. In de huidige situatie zijn het juist de ondersteunende specialismen en de dienstverlenende sectoren die gebudgetteerd zijn.

De ondersteunende specialismen zijn vergelijkbaar met diensten en hebben in de huidige situatie een budgetverantwoordelijkheid. Het is de vraag of de uiteindelijke verantwoordelijkheid niet meer thuishoort bij de poortspecialismen welke in feite de vraag initieren. De poortspecialismen vormen op dit moment nog eilanden in de gebudgetteerde omgeving en het voeren van onderhandelingen over het toekenmen van budgetten blift een moeizaam proces, zolang deze poortspecialismen deze zelfstandigheld behouden. Echte besluitvorming zal pas gerealiseerd kunnen worden indien deze poortspecialismen ingepast worden in de ziekenhuisorganisatie. Dit zou kunnen geschieden door de poortspecialisten de budgetverantwoordelijkheid toe te kennen. Deze verantwoordelijkheid zou zich moeten uitstrekken tot die kosten, welke het gevolg zijn van de handeling van deze poortspecialismen. Het voordeel van een dergelijke benadering is dat het budget betrekking heeft op de integrale behandeling van de patient. Dit zou in theorie onnodige diagnostische c.q. therapeutische handelingen kunmen voorkomen. 
De Landelijke Specialisten Vereniging (zie het rapport van de LSV "De specialist van morgen") opteert voor een hoofdrol voor de specialist in deze. De specialist zou vanwege zijn professionele deskundigheid zeer goed geęquipeerd zijn om de doelmatigheid van behandelingen te bevorderen. De manager, die enigszins thuis is op het terrein van de medische problematiek, komt voor een dergelijke functie echter evenzeer in aanmerking als de arts welke opgeleid moet worden tot manager. Indien de specialist echter de rol van budgethouder zou gaan spelen lijkt een dienstverband voor de specialist meer voor de hand te liggen, een ontwikkeling die ook op grond van andere overwegingen steeds waarschijnlijker wordt (Groot, 1987). Naast het aanleren van deze managementkwaliteiten is het voor de arts in een managementpositie noodzakelijk te beseffen dat "zorg voor individuele patiënten" verschilt van "het bevorderen van een kosten-effectieve zorg voor een groep patiënten" (Kwalenski e.a., 1987). Indien het voor de arts niet mogelijk is om deze duale verantwoordelijkheid te accepteren, dan is het zaak om in de organisatie van het ziekenhuis zodanige voorwaarden te scheppen dat ten aanzien van de besluitvorming een zekere gelijkwaardigheid gecreëerd wordt in de positie van de arts en het management.

\subsubsection{Budgettering en kosten-effectlef gedrag}

Over begrippenparen als "kosten en kwaliteit" en "efficiency en effectiviteit" (of wat hetzelfde is "doelmatigheid en doeltreffendheid") wordt in de gezondheidszorg vaak gesproken alsof het tegenstellingen betreft. Verbetering van de kwaliteit gaat in die opvatting altijd gepaard met toenemende kosten en evenzo leidt kostenbeheersing automatisch tot kwaliteitsverlies. De vraag is echter of kwaliteit en kosten altijd op een dergelijke wijze met elkaar verbonden zijn.

Uit hoofdstuk 3 blijkt reeds dat er weinig uniformiteit bestaat in het aanvraaggedrag van artsen. De variatie in testgebruik, geeft aan dat het enerzijds mogelijk moet zijn het testgebruik te reduceren zonder de kwaliteit van zorg aan te tasten (Boelen, 1985), of anderzijds bij gelijke middelenaanwending een hogere kwaliteit te bewerkstelligen. Soms wordt gesteld dat gezien de spanning tussen efficiency en effectiviteit eerst overeenstemming moet worden bereikt over welke doelstelling primair beïnvloed dient te worden. Verbetering van kwaliteit zal dan bijwoorbeeld moeten plaatsvinden gegeven de financiële randvoorwaarden en vermindering van kosten zal dan nagestreefd mogen worden als de kwaliteit maar gelijk blijft (Schwartz; 1979).

Bowen (1987) legt het primaat duidelijk bij de kostenverlaging. Vanuit de medische professie echter worden steeds meer geluiden opgevangen die aangeven dat met name aan het kwaliteitsaspect aandacht moet worden geschonken.

Zijn de doelstellingen, kostenbewaking en kwaliteitsverbetering wel zo tegengesteld aan elkaar?

Geen enkele econoom zal tenslotte willen bezuinigen tot het verzorgingsniveau gedaald is tot het absolute nulpunt en geen enkele arts zal verkondigen dat het Nationaal Inkomen geheel besteed moet worden aan gezondheidszorg. Het probleem is juist om het niveau te bepalen waarop kostenaspecten en medische kwaliteitsaspecten in een juist evenwicht met elkaar zijn.

De scherpe tegenstelling tussen kosten-en kwaliteitsaspecten kan worden verminderd, indien als doelstelling wordt geformuleerd: het produceren van effectieve zorg, tegen 
een verantwoord kostenniveau. Dat een dergelijke doelstelling nog lang geen gemeengoed is moge uit het onderstaande blijken.

Voor veel artsen is het onacceptabel dat economische overwegingen of maatschappelijke overwegingen betrokken worden bij beslissingen met betrekking tot individuele patiknten (Levinsky 1984). Ook Relman (1985) stelt zich de vraag of het in het belang is van de patient dat de arts de tak krijgt ook de ziekenhuiskosten te beheersen. Angell (1985) stelt dait de arts deze rol moet weigeren op grond van het feit dat er nog grote besparingen mogelijk zijn door minder gebruik te maken van zowel de lichte als de hoogwatardige technologieen; een uitspraak overigens die zijn elgen stelling ondergraaft Ook de uitspraak van Pellegrino is wat dit betreft veelzeggend: "decisions are required to do everything that they believe may benefit each patient without regard to costs on other societal considerations. In caring for an individual patient, the doctor must act solely as that patient's advocate against the apparent interests of society as a wholle (Pellegrino, 1978). Bekeken vanuit een economisch gezich tspunt kan dit alleen maar leiden tot misallocatie. De vraag is dan ook of de maatschappij zich een dergelijk luxueus standpunt kan veroorloven. De alternatieve opvatting zoals bijvoorbeeld verwoord door Wulff (1980) is ook te vinden bij Neuhauser (1976), Leaf (1984) en Thurow (1985). Deze houdt in dat de arts naast verantwoordelijkheid voor de individuele patient tevens ook een maatschappelijke verantwoordelijkheid heeft.

Ook Groot (1978) beschouwt doelmatigheid min of meer als een aspect van kwalitatief goede zorg. Evaluatie van de doelmatigheid van zorg kan zowel op basis van individuele patienten als op een meer geaggregeerd niveau plaatsvinden. Door het overwegend constante karakter van de ziekenhuískosten zijn de economische implicaties met betrekking tot individuele behandelingen uitermate gering. Anders ligt het indien gekeken wordt naar de consequenties van behandelingen op groepsniveau. Voor de arts blijft in eerste instantie de individuele patiënt voorop staan. De econoom zal meer geneigd zijn de invloed op infrastructurele veranderingen te analyseren van beslissingen ten aanzien van behandelingspatronen van patiënten op geaggregeerd niveau. Afgezien van het kostenaspect zijn er concrete factoren te noemen die eveneens tot hel inzicht leiden dat een zuiver medisch besliskundige benadering van individuele gevallen niet mogelijk is. Het referentiekader woor de beslissingen wordt namelijk afgeleid van onder andere de stand van de wetenschap met betrekking tot de onderhavige patientenproblematiek. Eveneens zijn kansen onmogelijk te schatten zonder de ervaring met gelijksoortige andere patienten. Voor het nemen van optimale beslissingen met betrekking tot individuele patiënten moet de arts geaggregecrde kennis met betrekking tot de groep patiènten transformeren tot relevante kennis voor deze ene patient.

Afweging van kosten- en kwaliteitsaspecten in de gezondheidszorg is een probleem dat speelt in ieder gezondheidszorgsysteem.

Om kosten-effectief handelen te stimuleren worden in de Verenigde Staten talloze experimenten uitgevoerd. Een interessante toepassing, welke plaatsvindt binnen Medicaid, is "case management" ook wel "gate-keeping" genoemd (Reagan, 1987). In dit systeem vervult éen bepaalde arts voor de patient de rol van kwaliteitsbewaker. Aldus wordt getracht te komen tot een efficientere behandeling. Een nadeel is dat de vrije artsenkeuze beperkt wordt. Er is gebleken dat dergelijke experimenten succesvol kunnen zijn in het beheersen van kosten, indien er aanvullende financiele incentives zijn of bepaalde vormen van risk-sharing om het gedrag van artsen te beïnvloeden (Freund, 1987). 
Ook in Engeland, met zijn jarenlange traditie op het terrein van de budgettering zijn er problemen bij de afstemming tussen kosten en kwalliteit. Indien de arts in een dergelijk systeem iedere patiènt als een apart geval beschouwt waaraan maximale zorg besteed moet worden, dreigt er snel inefficiency in het totale systeem In deze zin is de stelling zelfs te verdedigen dat de arts onethisch handelt indien hilj duizend gulden besteed aan een patiënt, die daar geen of nauwelijks baat bij heeft, terwijl andere patiènten, eventueel buiten zijn eigen afdeling, voor hetzelfide bedrag in principe meer gezondheidswinst hadden kunnen behalen (Maynard, 1987).

Met betrekking tot het referentiekader, van waaruit de arts en de econoom geneigd zijn te denken, is er sprake van een cruciaal onderscheid. De arts is geneigd beslissingen te nemen ten behoeve van individuele patienten, terwijl de econoom geconfronteerd wordt met de gevolgen van dit handelen op maatschappelijk niveau.

Wat is nu de specifieke invloed van de invoering van budgettering op de arts-econoom relatie?

Door de ontwikkelingen op het terrein van de budgettering zijn de financiele gremzen duidelijker geworden voor de arts. Budgettering heeft ervoor gezorgd dat de financielle ontwikkelingen zich voltrekken binnen van tevoren bepaalde kaders. Daarmee wordt de aandacht in eerste instantie afgewend van het kwaliteitsaspect of, om met Wickings (1987) te spreken, budgetteringssystemen sec stimuleren weliswaar efficiency-gedrag in enge zin, waarbij sterk de nadruk ligt op beperking van inzet van middelen, maar niet noodzakelijkerwijs kosten-effectief gedrag.

Binnen gebudgetteerde systemen is er bovendien een continue dreiging voor een verdergaand restrictief beleid. Volgens Wickings is nergens ter wereld nog maar een begin gemaakt met evaluatief onderzoek om na te gaan of vermindering van budgetten leidt tot (onaanvaardbaar) kwaliteitsverlies.

Ook in de Nederlandse gezondheidszorg ontbreken vooralsnog de prikkels voor een meer kosten-effectief gedrag van artsen.

De wijze van invoering van de interne budgettering heeft nog niet geleid tot een

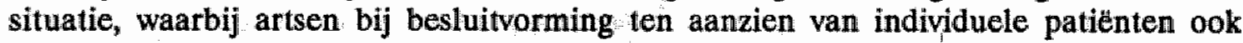
economische overwegingen een rol moeten laten spelen (zie voorgaande paragraaf). De druk die het gevolg is van budgettering is veel meer indirect, in de zin dat voorkomen moet worden dat er een te groot beroep wordt gedaan op de hulpafdelingen die wel gebudgetteerd zijn. Om kosten-effectief handelen van de arts te stimuleren is, zoals boven aangegeven, budgettering van poortspecialismen te prefereren ${ }_{*}$ Deze poortspecialismen zullen behoefte hebben aan behandelprotocollen, teneinde cen evenwichtige inzet van de schaarse middelen te bewerkstelligen. In deze protocollen zal zowel aan medische- als aan economische aspecten aandacht besteed dienen te werden. Het tot stand brengen van kosten-effectief handelen van artsen zal binnen dit kader en op dit niveau moeten plaatsvinden. Met name op het niveau van de kwaliteitstoetsing ligt de medische invalshoek dicht bij de economische benadering en kan een vruchtbare synthese ontstaan tussen arts en econoom, teneinde een doelmatige en doeltreffende gezondheidszorg te bewerkstelligen.

Medische beleidsplannen zullen het wensenpakket van de artsen kunnen bevatten. De confrontatie van deze medische beleidsplannen met de beschikbare financiële ruimte zal moeten leiden tot een infrastructuur, waarbinnen artsen een kwalitatief goede zorg kunnen leveren. Hantering van kosten-effectiviteitsoverwegingen bij de individuele patiënt zal dan plaatsvinden tegen de achtergrond van deze infrastructurele restricties. 


\subsection{IMPLICATIES VAN HET ONTWIKKELDE MODEL VOOR DE PRAKTIJK}

In voorgaande hoofdstukken is een aanzet gegeven tot de ontwikkeling van een besliskundig model waarmee optimale besllissingen genomen kunnen worden ten aanzien van het gebruik van tests.

Een relatief eenvoudige beslissing over het optimale gebruik van middelen, indien twee tests beschikbaar zijn, blijkt al gauw een vrij complex probleemveld te zijn indien alle mogelijkheden worden geanalyseerd (positiviteitscriteria, afkappunten, eventuele afhankelijkheid beslisregels).

In de dagelijkse medische praktijk zullen frequent beslissingen genomen moeten worden in situaties welke weel complexer zijn dan het hiervoor beschreven probleemgebied en waarbij bovendien de beslissing snel genomen moet worden. De tijd ontbreekt vaak voor een gedegen analyse. De vraag is dan ook gerechtvaardigd op welke wijze de hiervoor ontwikkelde modellen relevant kunnen zijn voor het besluitvormingsproces in de medische praktijk.

Voor de beantwoording van deze vraag is het nodig onderscheid te maken tussen de relevantie van het ontwikkelde model see en de relevantie van de inzichten over optimaal testgebruik welke gegenereerd kunnen worden met behulp van het model. Dit maakt duidelijk dat er een tweetal wegen zijn aan te geven waarlangs de resultaten van voorgaande analyse bruikbaar gemaakt kunnen worden voor de medische praktijk.

Aan de ene kant zullen de besliskundige inzichten, verkregen op grond van het model, als leidraad gebruikt kunnen worden bij de medische opleiding. Aan de andere kant kunnen het model en de besliskundige analyses gebruikt worden in de praktijk van het medisch handelen. Op deze twee aspecten zal hieronder nader worden ingegaan.

\section{de medische oplelding.}

De inzichten welke het model biedt, of welke gegenereerd kunnen worden met behulp van het model, kunnen via de opleiding doorgegeven worden aan artsen. Aldus kunnen deze nieuwe inzichten, welke met name betrekking hebben op de economische dimensie van het testgebruik, leiden tot een verandering in de attitude van een arts.

De inzichten zullen in het medisch curriculum, waar reeds aandacht besteed wordt aan de medische besliskundige aspecten van testgebruik ingebracht moeten worden. In het basiscurriculum kan dit door gezondheidseconomen danwel besliskundigen met feeling voor de specifieke economische benadering verzorgd worden. Voor de klinische fase, waarin de basisarts voor het eerst kennis maakt met de medische praktijk en de attitude voor het aanvragen van tests wordt gevormd, is het van belang dat de opleider zichzelf deze kennis en inzichten eigen maakt.

Naarmate het model in meerdere verschillende testsituaties in de praktijk wordt toegepast, zal er een beter begrip ontstaan aangaande de werking van tests. Wellicht is het dan mogelijk deze inzichten te vertalen in vuistregels. Voorbeelden daarvan zijn in het voorafgaande gesuggereerd.

- hanteer bij lage a priori kansen afkappunten met een hoge specificiteit.

- hanteer bij het combineren van tests bij lage a priori kansen een conjunctief positiviteitscriterium. 
- bij een hoge waarde van afhankelijkheid heeft een extra test relatief een gernge extra opbrengst tot gevolg.

Voor een verdere verfijning van dergelijke vaistregels en zelker woor hex verwerken want de economische dimensie erin, is nader onderzoek nodig.

\section{de medische praktijk}

In de voorafgaande hoofdstukken is veel aandacht besteed an het inzidhtelyjk mahen van de besliskundige methoden middels grafische presentaties en onderlinge vergelijking. Tevens is geexpliciteerd op welke punten het ontwikkelde model arrwitust op reeds bestaande modellen. Ook is veel energie gestoken in het verdwidelifiken wan de elementaire problematiek bij het testen. Specifieke aandacht is besteed an de volgende vragen:

- Hoe verhoudt paralleltesten zich tot serietesten?

- Wat is het effect van het hanteren van een bepaald positiviteitscriterium?

- Wat is het effect van afhankelijkheid van tests?

- Wat is de efficiency-winst bij het hanteren van het optimale afkappunt?

De opgedane kennis en verworven inzichten kunnen door artsen aangewend worden om in voorkomende situaties meer bewust dan voorheen beslissingen omtrent het gebruik van tests te nemen. Voor een aantal eenvoudige situaties zijn in voorafgaande hoofdstukken zelfs beslisregels geformuleerd welke hiertoe handwatten bieden.

Het hiervoor beschreven model kan ook aangewend worden om in voorkomende situaties berekeningen te maken met betrekking tot de optimale inzet van tests.

Met name voor de patiëntenproblematiek waarmee artsen relatief frequent worden geconfronteerd, kunnen besliskundige analyses gemaakt worden. Vervolgens kunnen de resultaten worden samengevat in de vorm van protocollen. In deze protocollen zallen de meest recente gegevens uit de literatuur moeten worden samengevat. Ontbrekende gegevens zouden wellicht via consensus-meetingen kunnen worden aangevuld.

Vervolgens zou deze aanpak kunnen worden aangewend om bij nieuw te ontwerpen protocollen rekening te houden met de economische consequenties.

Zoals gezegd zal de problematiek zoals deze zich in de praktijk voordoet, vaak gecompliceerder zijn dan de complexiteit die het voorafgaande model aan kan. Het model zal daartoe verder uitgebreid moeten worden om ook in deze complexere situaties oplossingen te kunnen bieden.

Een derde toepassing van het model is de ondersteuning van managementbeslissingen over aanwending van middelen op afdelingsniveau. Met het model en eventueel de in de toekomst te ontwikkelen varianten, waarmee meer gecompliceerde diagnostische situaties kunnen worden geëvalueerd, is het management in staat aan te geven in welke deelgebieden bezuinigingen op testgebruik het beste kunnen plaatswinden, zodanig dat de patient zo weinig mogelijk schade ondervindt. Vanzelfsprekend zal een dergelijke toepassing slechts in naww overleg met de betreffende specialisten kunmen worden uitgewerkt. Het is de bedoeling dat in het Academisch Ziekenhuis Maastricht in de nabije toekomst experimenten uitgevoerd gaan worden om na te gaan of met behulp 
van besliskundige analyses het gebruik wan diagnostische middelen geoptimaliseerd kan worden.

Voor het optimaliseren van het testgebruik is een verdere ontwikkeling van het evaluatiemodel, zoals dat hiervór is omschreven, noodzakelijk. Er resteert echter een antal knelpunten, zowel op organisatorisch niveau als op technisch-inhoudelijk terrein. Deze knelpunten zijn er de oorzak van, dat toepassing van besliskundige technieken in de medische praktijk gecompliceerd is. Hieronder zal een aantal van deze knelpunten worden besproken en suggesties worden gedaan ter verbetering van de voorwaarde voor toepassing van besliskundige technieken in de praktijk.

Voor toepassing wan besliskundige technieken in de medische praktijk is het noodzakelijk om de beschikking te hebben over diverse soorten gegevens. Bij diagnostische tests gaat het veelal over gegevens met betrekking tot kansen:

- de a priori kans

- de sensitiviteit en specificiteit

- de kansen op gezondheidsverbetering

- de risico's.

Daarnaast zijn voor het model gegevens vereist als:

- de waardering van gezondheidstoestanden

- de maximumwarde van een QALY.

De a priori kans blijkt een belangrijke factor te zijn bij het bepalen van de optimale teststrategie. Een redelijke nauwkeurige schatting van de a priori kans is dus vereist. Om het model toe te kunnen passen dient voor iedere patient een inschatting van de a priori kans gemaakt te worden.

Hiervór is reeds aangegeven dat dit een gecompliceerd proces is met talloze valkuilen. Een mogelijkheid om te komen tot meer betrouwbare schattingen van de a priori kans is het opzetten van gegevensbestanden van patiènten. Deze gegevensbestanden dienen gedetailleerde informatie te bevatten over klachten en symptomen teneinde het mogelijk te maken woor de individuele patiënt een schatting te maken van de a priori kans.

In het model wordt gerekend met kansintervallen van 0,01 . In de medische praktijk moet het uitgesloten geacht worden te komen tot schattingen van een dergelijk gedetailleerd niveau. Als eerste stap zou het wellicht haalbaar zijn om kansinschattingen te maken, warbij intervallen van 0,05 of misschien zelfs wel 0,1 worden gehanteerd.

Ter bepaling van sensitiviteit en specificiteit van tests, evenals de bepaling van effecten vain therapeutische interventies is nader onderzoek vereist. De sensitiviteit en specificiteit van tests zijn vaak niet bekend. Als deze parameters al bepaald zijn dan is het nog maar de vraag of de onderzoeksomgeving waaruit de parameters afkomstig zijn voldoende owereenkomst vertoont met de specifieke praktische omgeving. Nog gecompliceerder dan het bepalen van de sensitiviteit en specificiteit van de test is het bepalen van de uitkomsten van een therapeutische behandeling. Meestal zijn er bij een behandeling vele mogelijke uitkomsten, ieder met een bepaalde waarschijnlijkheid van optreden. Door middel van de beslisboom-techniek kunnen deze mogelijkheden in kaart gebracht worden. De betreffende waarschijnlijkheden dienen geschat te worden. Echter, alvorens de verwachtingswaarde te kunnen bepalen, dienen de diverse uitkomsten (gezondheidstoestanden) gewaardeerd te worden. Methoden waarmee dit veel geschiedt 
zijn onder andere Standard Gamble en Time Trade Off. Deze instrumenten zullen nog verder ontwikkeld en gevalideerd dienen te worden, voordat een algemene toepassing in de praktijk voor medici acceptabel is.

Een ander waarde-oordeel dat noodzakelijk is voor toepassing van kosteneffectiviteitsanalyses in de gezondheidszorg betreft de maximumwaarde van een QALY. Als dit onderzoek iets benadrukt, dan is het wel het feit dat deze waardebepaling een rol vervult ten aanzien van de optimalisering. Via K/O-berekeningen kan dit probleem in eerste instantie omzeild worden. Via $\mathrm{K} / \mathrm{O}$ berekeningen kan een volgorde worden gecreëerd binnen een aantal te ondernemen projecten c.q. activiteiten. Toepassing van dit principe op het terrein van testgebruik kan leiden tot een minder dan optimaal testgebruik.

O-K-berekeningen kunnen dan dienen als richtsnoer voor de optimale teststrategie. In deze laatste berekeningen dient de waarde van een QALY bekend te zijn. Methoden om deze waarden te bepalen ontbreken vooralsnog. Indicaties omtrent de waarde ervan kunnen echter afgeleid worden van het uitgavenpatroon in overige delen van het gezondheidszorgsysteem. Op dit moment zijn er nog te weinig onderzoeksresultaten op dit terrein bekend voor een toepassing van de O-K-benadering in de praktijk. 


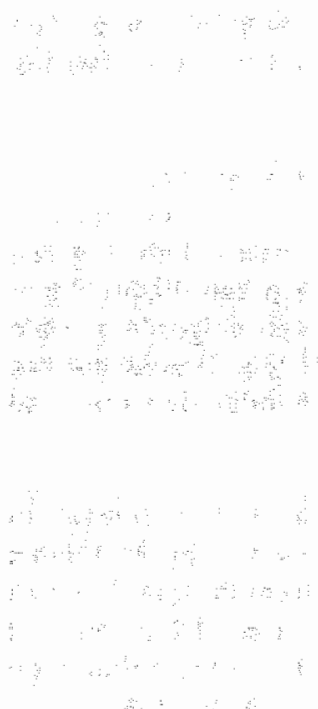




\section{SAMENVATTING}

De dagelijkse medische routine in het ziekenhuis is relatief weinig bestudeerd door gezondheidseconomen. Daarbi] is het bovendien zo dat het gebruik van diagnostische verrichtingen veel minder aandacht heeft gekregen dan het gebruik van therapeutische verrichtingen. Een en ander wordt mede veroorzaakt door het feit dat tests worden toegepast in situaties gekenmerkt door onzekerheid.

Vanuit de klinisch epidemiologische hoek wordt reeds gedurende enkele tientallen jaren gepleit voor toepassing van besliskundige technieken teneinde het testgebruik door artsen te optimaliseren. In deze dissertatie worden dergelijke methoden bekeken vanuit een economisch perspectief. Daarbij wordt de vraag beantwoord of de besliskundige methoden ontwikkeld kwnnen worden tot een instrument, waarmee het medisch handelen geoptimaliseerd kan worden. Over- zowel als ondergebruik van tests kan dan worden verminderd, hetgeen leidt tot een meer efficiente en/of effectieve gezondheidszorg.

Tests worden hoofdzakelijk aangevraagd ten behoeve van de screening, monitoring of diagnostiseren van ziekten. De wijze waarop artsen tot een diagnose geraken is gedeeltelijk onbekend. Vermoedellijk worden in de praktijk elementen van de hypothetico-deductieve wijzen, als ook van patroonherkenning aangewend. Evaluatie van het testgebruik kan betrekking hebben op proces-kenmerken (betrouwbaarheid), maar ook op de validiteit of de effectiviteit. Op deze twee laatst genoemde niveau's wordt nader ingegaan.

Sinds 1983 is het aantal laboratoriumtests, waarschijnlijk mede onder invloed van de budgettering, nauwelijks meer toegenomen. Door de voortschrijdende automatisering is een verschuiving opgetreden in de produktiekosten. Het aandeel van de variabele kosten is verminderd ten opzicht van het aandeel van de vaste kosten.

In een laboratorium dat gekenmerkt wordt door een hoge graad van automatisering is hierdoor relatief minder effect te verwachten van een strategie die beoogt de vraag naar tests in te perken dan het geval is bij een lage automatiseringsgraad.

Het laboratorium dient gezien te worden als een onderdeel van de medische dienstverlening. Het laboratorium verschaft informatie aan de artsen. Deze informatievoorziening is alleen dan zinvol, indien er een daadwerkelijke behoefte aan informatie bestaat. Dit is het geval indien de informatie een rele betekenis heeft in het beslissingsproces van de arts. Maatregelen die vanuit het laboratorium genomen kunnen worden om de vraag naar tests in te perken, zouden dan ook meer gericht moeten zijn op het bevorderen van een rationeel testgebruik dan op het ruwweg opwerpen van drempels voor de arts.

Een zekere stroomlijning van het aanvraaggedrag van artsen lijkt hard nodig, gezien de enorme variatie in testgebruik. Verschillen in aanvraaggedrag zijn terug te voeren op persoonsgebonden factoren van de arts (leeftijd, risicogeneigdheid etc.) als ook op instituutsgebonden factoren (universitaire kliniek versus ziekenhuis). Een belangrijke factor blijkt de genoten medische opleiding. Experimenten om het aanvraaggedrag van medische studenten te beinvloeden via de medische opleiding laten een meestal tijdelijk effect zien. Sociale, financièle en professionelle druk blijkt in de praktijk overheersend. Experimenten met feedback en intercollegiale toetsing laten wisselende resultaten zien. 
Meer effect hebben combinaties van strategieèn waarbij aan de ene kant aandacht besteed wordt aan het creëren wan inzicht in effectief testgebruik, waarbij artsen worden aangesproken op hun rationaliteit, en aan de andere kant een prikkel wordt gehanteerd om deze inzichten in de praktijk toe te passen. Binnen de Nederlandse gezondheidszorg vormen de verdere uitwerking en toepassing van de principes van interne budgettering hiervoor een goede basis.

Bij de evaluatie van een dichotome test wordt vaak gebruik gemaakt van de sensitiviteit on de specificiteit van de test. In de Bayesiaanse benadering worden deze testparameters, te samen met de a priori kans, gebruikt om de voorspellende waarden van positieve of negatieve testuitslagen te berekenen. In de ROC-curve wordt de tradeoff tussen sensitiviteit en specificiteit weergegeven. Vaak is het mogelijk door het kiezen van een ander afkappunt verbeteringen aan te brengen in de ene testparameter ten koste van de andere parameter. Om de onzekerheidsreductie ten gevolge van de uitwoering van de test te kwantificeren worden in de literatuur diverse mogelijkheden beschreven. Een tweetal modellen is in een vergelijkende studie betrokken:

- het model van Connell en Koepsell, waarbij het verschil in a posteriori en a priori kans gewogen wordt met de kans van optreden van de testuitslag.

de entropiebenadering maakt gebruik van het bits-concept; zoals dat oorspronkelijk door Shannon vorm is gegeven.

Uit de vergelijking van deze twee benaderingen blijken drie verschillen:

het model van Connell en Koepsell is minder volledig dan het model van Shannon omdat slechts de onzekerheidsreductie ten gevolge van juiste uitslagen wordt berekend. Bij Shannon worden ook de foute uitslagen meegenomen. de entropiebenadering is minder bruikbaar in het kader van evaluatie, waarbij ook de uitkomsten van het zorgproces een rol spelen

bij de afweging van de sensitiviteit versus de specificiteit van een test dient de a priori kans mede een rol te spelen. Bij Connell en Koepsell blijkt de a priori kans geen rol te spelen ten aanzien van dit keuzeprobleem. Bij het entropieconcept blijkt deze invloed wel aanwezig.

Beide berekeningswijzen zijn toegepast op een rekenvoorbeeld ontleend aan Galen en Gambino. Er kunnen enkele kanttekeningen geplaatst worden bij de conclusies van bovengenoemde auteurs.

Galen en Gambino concluderen dat de paralleltest de hoogste sensitiviteit en de laagste specificiteit heeft. Deze conclusie blijkt bij nadere analyse het gevolg van het gehanteerde positiviteitscriterium.

In verband met de optimale volgorde van tests concluderen Galen en Gambino dat eerst de test met de hoogste specificiteit dient te worden uitgevoerd. Voor het bepalen van de optimale volgorde bij een seriebenadering dient echter naast de specificiteit ook de sensitiviteit, de kostenverhouding en tenslotte de a priori kans bekend te zijn.

Bij de volledige evaluatie van de werking van een test spelen vier kosten (C) en vier opbrengsten (Q) factoren een rol. De consequenties horen bij de vier mogelijke testuitslagen: terecht positief (TP), fout positief (FP), fout negatief (FN) en fout positief (FP).

Bij een economische evaluatie wordt onderscheid gemaakt in een Opbrengsten - Kosten $(\mathrm{O}-\mathrm{K})$-criterium en in een Kosten gedeeld door Opbrengsten $(\mathrm{K} / \mathrm{O})$-criterium. Nadere analyse makkt duidelijk dat, indien het produktieniveau bepaald is door het K/O- 
criterium de totale winst geringer is dam indien bepaald door het 0 -K-criterium. Dit zou kunnen inhouden dat volgens het $\mathrm{K} / \mathrm{O}$-criterium een sub-optimale oplossing wordt gevonden. Echter indien de middelen, welke in de $\mathrm{K} / \mathrm{O}$-oplossing nog vrij zijn, aangewend worden in alternatieve richtingen, waar de gemiddelde opbrengst minimaal gelijk is aan de gemiddelde opbrengst bij $\mathrm{K} / \mathrm{O}$, dan is de totale winst groter dan of gelijk aan de totale winst bij $\mathrm{O}-\mathrm{K}$

In de literatuur worden verschillende modelspecificaties aangetroffen die gehanteerd worden om het optimale afkappunt op de ROC-curve te bepalen.

De meeste modellen zijn benaderingen waarin op verschillende wijzen rekening wordt gehouden met de diverse opbrengsten- oq. kostenconsequenties. In de meest wolledige economische evaluatie ( $\mathrm{O}-\mathrm{K}$ model) wordt het optimale afkappunt gevonden door een raaklijn met een richtingscoëfficiënt gelijk aan het produkt van de recipproke van oddsratio en de werlies/winst-verhouding (R), aan de ROC-curve te trekken.

Grafisch kan het optimale afkappunt in de K/O-benadering worden bepaald door vanuit het punt, waar zowel de kosten als de opbrengsten gelijk zijn aan 0, de raaklijn te trekken aan de ROC-curve. Bewezen kan worden dat alle combinaties van sensitiviteit en specificiteit welke gekenmerkt worden door eenzelfde $\mathrm{K} / \mathrm{O}$-verhouding, liggen op een rechte lijn door het betreffende 0 -punt.

Vervolgens wordt de analyse gericht op de evaluatie van een test waarbij vooral gekeken wordt naar de extra opbrengst van de test ten opzichte van de alternatieven "niets doen" of "onmiddellijk behandelen". Zonder de teststrategie is er cen bepaalde drempelwaarde voor de a priori kans ( $\mathrm{p}_{\mathrm{m}}$ ). Voor waarden kleiner dan $\mathrm{p}_{\mathrm{m}}$ is de strategie "niets doen"' het beste. Voor p-waarden groter dan $\mathrm{p}_{\mathrm{m}}$ is "onmiddellijk behandelen" het beste. Er zijn twee drempels $\left(p_{t}\right.$ en $\left.p_{b}\right)$ die de grens markeren waarbinnen de teststrategie prevaleert.

In de aldus onderscheiden gebieden blijkt de test zich op verschillende wijzen te gedragen. In het gebied $\left(\mathrm{p}_{\mathrm{t}}<\mathrm{p}<\mathrm{p}_{\mathrm{m}}\right)$ is slechts de positieve testuitslag van belang. Bij een negatieve testuitslag wordt de kans op de ziekte geringer, maar dit heefi geen effect op de te nemen beslissingen. Bij een positieve testuitslag wordt de kans op de ziekte groter en wordt "onmiddellijk behandelen" de optimale strategie, terwijl zonder test "niets doen" de voorkeur had. Uit 4 blijkt dat aan de hand van de likelihood-ratio van de positieve testuitslag, in combinatie met de factor $\mathbb{R}$, kan worden afgelezen of het verrichten van de test zinvol is. Met behulp van $5 \mathrm{kan}$ op de ROC-curve onderscheid gemaakt worden tussen zinwolle en niet-zinvolle afkappunten.

Combineren van twee onafhankelijke tests kan geschieden in serie of parallel. Bij een serietest kan de volgorde van de beide tests nog worden gevarieerd. Bovendien kan zowel bij de serie- als bij de parallelcombinatie een conjunctief danwel een disjunctief positiviteitscriterium worden gehanteerd. Het aantal strategieën, inclusief "miets doen" en "onmiddellijk behandelen" bedraagt dan 10 . Hebben beide tests echter meerdere mogelijke afkappunten dam neemt het aantal teststrategieen snel toe. Een conjunctief positiviteitscriterium leidt tot een test met een relatief lage sensitiviteit en een relatief hoge specificiteit, terwijl omgekeerd bij en disjunctief positiviteitscritterium de specificiteit relatief laag is in combinatie met de relatief hoge sensitiviteit.

Bij hantering van een zelfde positiviteitscriterium leiden de serie- en parallelbenadering tot dezelfde sensitiviteit en specificiteit. 
Bif lage a priori kansen is een conjunctief criterium wenselijk, bij hogere a priori kansen heeft een disjunctief criterium de voorkeur:

Bij combinalie van twee afhankelijke tests blijkt bij een conjunctief positiviteitscriterium de sensitiviteit hoger (en dus de specificiteit lager) dan het geval is bij onafhankelijke tests. Bij hantering van een disjunctief criterium is de invloed omgekeerd.

Kan de besliskundige methode in de medische praktijk aangewend worden bil het nemen van besllssingen?

Voor het toepassen van besliskunde is het noodzakelijk om een aantal factoren te expliciteren en te kwantificeren, die anders impliciet en mogelijk onbewust besluitworming beinvloeden. Problemen bij het kwantificeren zijn bekend: ze hebben betrekking op alle factoren welke in het model een rol spelen (de a priori kans, de testparameters, de sensitiviteit en specificiteit, de gezondheidswinst en de testkosten). Hoe kunnen sensitiviteit en specificiteit bepaald worden indien de gouden standaard ontbreekt? Zjjn er voldoende betrouwbare en valide methoden om gezondheid te meten? Wat is de maximale bereidheid van de maatschappij om voor gezondheid te betalen?

Verdere invoer van besliskundige technieken in de medische praktijk zall niet van vandaag op morgen gerealiseerd zijn. Door de invoering van de interne budgettering is een situatie gecrecerd waarbij de prikkels voor de arts om teveel tests aan te vragen zijn weggenomen. Echter voordat er van een omgekeerde situatie sprake is zal de arts veel sterker geconfronteerd thoeten worden met de financiële grenzen, eventueel door het testgebruik cen integraal onderdeel te laten zijn van het afdelingsbudget. Alleen dan zal de arts bij de besluitvorming kosten-en kwaliteitsaspecten laten meespelen.

Langs twee wegen kunnen echter de resultaten van voorgaande analyses toch bruikbaar gemaakt worden voor individuele besluitvorming. De ene weg betreft ontwikkeling van protocollen. In dergelijke protocollen zouden de consequenties van het testgebruik kunnen worden verwerkt, warbij meer dan tot nu toe het geval was de economische kant benadrukt wordt.

De tweede weg volgt het pad van de medische opleiding. De beslisregels en de inzichten die daaraan ten grondslag liggen kunnen via de medische opleiding doorgegeven worden aan medische studenten, maar ook aan praktiserende artsen. Dit maakt het mogelijk dat er op een meer doordachte wijze dan voorheen beslissingen omtrent het gebruik van tests zal worden genomen. 


\section{SUMMARY}

In the past health economists have paid little attention to the economic aspects of routine activities of doctors. In addition utilization of diagnostic procedures is less frequent studied than the use of therapeutic activities. This is due to the fact that tests are applied in a situation of uncertainty.

Clinical epidemiologists argue for the application of decision analytical techniques for optimizing test utilization. In this dissertation these techniques are studied from the economic point of view. An important question to be answered is how these techniques can be used as an instrument for optimizing medical decisions. Over- as well as underuse can be reduced to attain a more efficient and/or effective health care system.

Tests are mainly ordered for a screening, monitoring or diagnostic function. The diagnostic process, the way how doctors reach a diagnosis, is not fully understood. In their daily practice, doctors use elements of the hypothetico-deductive approach, as well as elements of pattern recognition. Evaluation of the use of tests can be done on the level of the process (reliability), but also on the level of validity or effectiveness. These two levels in particular are studied and described in this dissertation.

Since 1983 laboratory production has been stabilized, caused by the budgeting of hospitals and other factors. Automation in the laboratory has caused a shift in the balance of variable and fixed costs. In a laboratory with a high degree of automation, a great effect from a strategy aimed at the reduction of the demand for tests by doctors is not expected.

The laboratory is a part of medical services. It provides the doctor with information. This information supply is only useful if it has a real significance for the decision process of the doctor. Measures to restrict the demand for tests should be aimed more at promoting rational use of tests at creating thresholds for the doctor.

Regarding the enormous variation in the use of tests among doctors, some kind of understanding of the behaviour of ordering tests is necessary. Differences in test utilization are partly caused by personal characteristics of the doctor (age, risk behaviour, etc.) and partly by structural factors (university hospital). Medical education also plays a very important role. Experiments to influence the use of tests by educational interventions show a temporary effect. Social, financial and professional pressures are dominant.

Experiments with feedback and medical audit show different results. More success can be expected from combinations of strategies, in which on the one hand attention is paid to creating knowledge about effective test use, and on the other hand an incentive is created for applying this knowledge in practice. Within the Dutch health care system the further application of the prineiples of internal budgeting seems to be a starting point.

For evaluating a dichotomous test, sensitivity and specificity of the test are often used as an optimization criterion. In the Bayesian approach these test parameters, together with the a priori probability, are used to calculate predictive values of positive or negative test results. The ROC-curve shows the trade-off between sensitivity and specificity. To quantify the amount of reduction of uncertainty, caused by the test performance, different methods can be used. Two models are compared:

- the model of Connell and Koepsell, by which the expected value of the difference between a posteriori and a priori probabillity, given a positive or a negative test result, is calculated. 
Comparison of these two models show the following differences:

the model of Connell and Koepsell is less complete than the model of Shannon, because it only takes into account the reduction of uncertainty caused by correct test results (bits). The method of Shannon incorporates the false results as well. the entropy method cannot be used in evaluations aimed at the outcomes of medical interventions.

in determining the optimal cut-off point of a test the a priori probability should play a role. In the Connell and Koepsell model this is not the case, whereas in the entropy approach this factor is used.

Both methods of calculating the reduction of uncertainty have been applied to an example derived from Galen and Gambino.

Galen and Gambino conclude that parallel testing has a higher sensitivity and a lower specificity than series testing. Further examination shows that this conclusion is exclusively based on the value of the positivity criterion of the two test combinations. They conclude that in a series test for reasons of efficiency the test with the highest specificity should be done first. However, for determining the optimal sequence, the sensitivity, the test costs and the a priori probability should also be known.

Regarding complete evaluation of test utilization there are four important costs (C) and four important outcomes $(Q)$. These consequences belong to the four possible test results: true positive (TP), false positive (FP), false negative (FN) and true negative (TN).

In an economic evaluation a "Benefit minus Cost" criterion (B - C) or a "Cost divided by Benefit" criterion ( $\mathrm{C} / \mathrm{B}$ ) can be used. If a production level is determined by the $\mathrm{C}$ I B criterion, the total profit is lower than the total profit determined by the B - C criterion. Theoretically using a C / B criterion could lead to a suboptimal solution. However, if the resources not used in the C/B solution are applied to alternative situations, where the average benefit is at least as high as the average benefit in the C / B solution, then the sum of these profits is the same (or higher) than the total profit determined by the $\mathrm{B}-\mathrm{C}$ criterion.

Optimization according to the C/B criterion leads to a lower use of tests than optimization according to $\mathrm{B}-\mathrm{C}$ criterion. Before using this criterion, the amount of health gained expressed in terms of, for example, Quality Adjusted Life Years (QALY's) should be determined, as well as the monetary value (M) of this gain. The factor $M$ represents the maximum social willingness to pay for a QALY. The B - C approach seems to function as a maximum admissible solution for C / B calculations. If the costs per QALY in the optimal solution according to the C / B approach is far below the maximum value $M$, additional claims for more expensive test strategies can arise.

Determining the optimal test strategy in a fairly uncomplicated situation (for example a combination of two tests with several possible cut off points) is so complicated that the aid of computer programmes becomes necessary.

In the literature, several specific models for determining the optimal cut-off point on the ROC-curve can be found. Most of these models contain different incomplete combinations of casts and/or benefits as consequences. The most complete economic 
evaluation model can be found by determining the optimal cut-off point by drawing a line with a slope $(R)$ equal to the product of the reciprocal of the odds ratio and the loss/benefit ratio, intersecting the ROC-curve. This model is the specification of the C - B approach.

Graphically, the optimal cut-off point can be found in the C - B approach by drawing a line, touching the ROC-curve, from a point where costs as well as benefits are equal to zero. Further, it can be shown that all combinations of sensitivity and specificity, characterized by the same C/B ratio, can be localized on a straight line. The point where costs and benefits are zero is also found on this line.

Besides this economic evaluation model, the analysis deals with the alternatives "doing nothing" and "treating". Without the test strategy, there is a certain threshold for the a priori probability $\left(\mathrm{P}_{\mathrm{m}}\right)$. For values of the a priori probability smaller than the threshold $p_{m}$, the strategy "doing nothing" is optimal. For values of the a priori probability values higher than $\mathrm{p}_{m}$, the strategy "treating" is optimal. The test strategy of testing is characterized by two thresholds. One threshold represents the decision between the strategy of "doing nothing" and testing ( $p$ ). The other threshold represents the decision between the strategy of testing and "treatment without testing" $\left(\mathrm{p}_{\mathrm{b}}\right)$. For values of the a priori probability between $\mathrm{p}_{t}$ and $\mathrm{p}_{\mathrm{b}}$, the test strategy is the optimal strategy.

In the area where the value of the a priori probability lies between $p_{t}$ and $p_{m}$, only the positive test result is an important indicator for decision-making. The probability of disease given a negative test result is less than the a priori probability, but has no impact on the decision. In case of a positive test result, however, the a posteriori probability is higher and the strategy "treating" becomes preferable, whereas without the test, "doing nothing" is the best strategy. Further, it can be concluded that the decision to test or not to test can be based on the likelihood ratio and the factor $R$ (see above).

Combination of two independent tests can be done in series or parallel. In case of series testing the sequence of tests can be changed. In both combinations (series and parallel) a conjunctive positivity criterion (both tests have to be positive) or a disjunctive positivity criterion can be applied.

There are ten strategies available, including the strategy "doing nothing" and "treating". Using a conjunctive positivity criterion leads to a test with a relatively low sensitivity and high specificity and vice versa. By using the same positivity criterion the series and parallel combination have identical sensitivity and specificity.

With low a priori probability, a conjunctive positivity criterion is desirable, with high a priori probability a disjunctive positivity criterion. Combination of two dependent tests leads with a conjunctive positivity criterion to a higher sensitivity (and lower specificity) than in case of combination of two independent tests. Using a disjunctive positivity criterion the relation is reversed.

\section{Can the decision analytic approach be applied in medical practice?}

For the application of decision analysis it is necessary to quantify a number of factors explicitly, factors that otherwise influence the decision making process implicitly.

Problems of quantifying these factors are known: they include the assessment of a priori probability, sensitivity and specificity, outcomes in terms of QALY's, and the test costs. Relevant information about these factors is often lacking. A structural problem 
is the lack of a gold standard in many cases. How can the sensitivity and specificity be determined, if a gold standard is lacking? Are the methods to measure improvements in health status reliable and valid? What is the maximum amount that society is willing to pay for QALY's.

Introduction of decision analytical methods in medical practice will take a long time. By budgeting hospitals, a situation has been created with inherent incentives for test reduction. However, financial incentives will have to be strengthened; which could be realized by creating clinical budgets including the costs of tests. In that case the doctor will have to integrate the quality and costs aspects in his clinical decision making.

Mainly there are two ways for using the results of decision analysis.

One way is the development of protocols. In these protocols the consequences of the use of tests could be analyzed, including the economic dimension. The second way uses the medical education. Decision rules, and the knowledge on which these rules are based, can be taught to medical students, but also to doctors by means of postdoctoral courses. More rational use of tests could be the result of this educational strategy. 


\section{LITERATUURLIJST}

Adelstein, S., , Pitfalls and biases in evaluating diagnostic technologies, Uit: McNeill, B,J, and E,O, Cravalho, 1982.

Albert, A., On the use and computation of likelihood ratios in clinical chemistry, Clin. Chem, 28, pp: $1113-1119,1982$.

Alderson, P.O, D.F. Adams, B.J, McNeill et al, Computed Tomography Uttrasound and Scintigraphy of the liver in: Patients with colon or breast cancer: A prospective comparison, Radiology, 149, pp. $225-230,1983$.

Altshuler, $\mathrm{CH}$. Use of laboratory tests, Ann. Intern. Med., 95: pp. 237, 1981.

Ament, A, L. Bedaux, R. Mercx, T. Vissers, Kosten en kwaliteit in de intramurale gezondheidazorg, Tijdstroom, Lochem, 1985.

Ament, A, M. Sprenger, Evaluatie van het diagnostisch proces: een benadering vanuit een kosten-baten perspectief, Uit: Ament, A. e.a., 1985.

Ament, A, Toepassing in de gezondheidszorg van de analyses kosten-baten en kasten-effektiviteit, Acta Hospitalia, XIX, 1, pp. 3-24, 1979 .

Ament, A., G. Haan en G. Heemells, Kosten-effektiviteitanalyse open hart chirurgie, Rijksuniversiteit Limburg, Maastricht, 1986.

Ament, A., M. Sprenger, Evaluatie van diagnostiek, T.M.I., 15: 1986.

Andriessen, J.E., Economie in theorie en praktijk I en II, Elsevier, Amsterdiam, 1980.

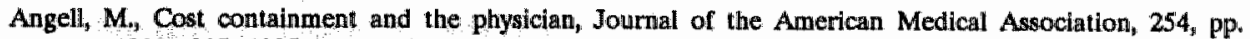
$1203-1207,1985$.

Applegate, W.B., Decision theory for cliniclans: uses and misuses of clinical tests, South Med. J., 74: pp. $468-473,1981$.

Barnoon, S., H. Wolfe, Measuring the effectiveness of medical decisions, Charles C. Thomas Publishers, Springfield, USA 1972.

Barr, J.T., A priori considerations when using laboratory determinations in cost-effectiveness and clinical decision analyses, Am. J. Med. Technol., 47: pp. 619-629, 1981.

Barth, R.T., I. Vertinsky et al., Factors affecting physiclans' use of laboratory technology in diagmosis, Uit: Pickett, R.M. et al., 1975.

Beck, J.R., The role of new laboratory tests in clinical decision-making, Clin. Lab. Med., 2: pp. 751-777, 1982.

Begg, C.B. Blases in the assessment of diagnositic tests, Statistics in Medicine, 6: pp.411423, 1987.

Begley, C.E., Physicians and cost control, Uit: Agich, G.J. et al., 1986.

Bennington, J.L., Cost control of laboratory lesting, Uit: Halsted, J.A. et al., 1981.

Benson, E.S., Strategies for improved use of the clinical chemistry laboratory. Uit: Benson E.S. ett al., 1978.

Benson, E.S., M. Rubin, Logic and economics of elinical laboratory use, Elsevier, New York, 1978.

Berwick, D.M. K. L Coltin, Feedback reduces test use in a Health Maintenance Organization, JAMA, 255: pp.1450-1454, 1986. 
Billings, P.R., M.S.Bernstein; Physicians poor at prevalence and positive predictive value, JAMA, 254: pp. 1173-1174, 1985.

Birch, 3 , and C. Donaldson, Cost-benefit analysis dealing with the problems of indivisible projects and fixed budgets, Heallh Pol., 7: pp. 61-72, 1987.

Birch, $s_{\text {if }} C$. Donaldson, Applications of cost-benefit analysis to health care, Journal of Health Economics, 6. pp. 211-225, 1987.

Blades, C.A.AJ. Culyer and A Walker, Health service efficiency: appraising the appraisers- a critical review of economic appraisal in practice, Soc. Sc. Med. 25,5 , pp. 461-472, 1987.

Blawwens, AJ., De tijd, de dood en het comfort, Erasmus Universiteit Rotterdam, 1984, 11 Oct.

Bolce, J.L, M. McGregor, Effect of residents" use of laboratory tests on hospital costs, J, Med. Educ, 58: pp. 61-64, 1983.

Bowen, OR, Shattuck lecture-What is quality care ? N. Engl. J. Med., 316, 25, pp. 1578-1586, 1987.

Broughton, P.M., T.C.Hogan, A new approach to the costing off clinical laboratory tests, Ann. Clin. Biochem., 18. pp. $330-342,1981$.

Buettner, H., Effective utilization of the clinical laboratory: a laboratory directors' viewpoint, Uit: Benson, E.S. et all, 1978 .

Buettner, J., Grundlagen der Anwendung der Informationstheorie auf qualitative klinisch-chemische Untersuchungen, J. Clin. Chem. Clin. Biochem., 20: pp. 477-490, 1982.

Buettner, J., Die Beurteiling des diagnostischen Wertes klinisch-chemischer Untersuchungen, J. Clim. Chem. Clin. Biochem., 15: pp. 1-12, 1977.

Burke, M.D., Assessing the clinical utility of laboratory methods, Clin. Lab. Med., 1: pp. 21-37, 1981.

Burke, M.D., Clinical problem solving and laboratory investigation: contributions to laboratory medicine, Prog. Clin. Pathol., 8: pp. 1-24, 1981.

Campbell, E.J.M., Basic science and medical education, Lancet, pp. 134-136, 1976.

Card, W.I., P.A. Emerson, Test reduction: I-Introduction and review of published work, Br. Med. J., pp. 543-545, 23 aug. 1980 .

Casscellis, B.S, A Schoenberger, T.B. Graboys, Interpretation by physicians of clinical laboratory results, N. Engl. J. Med, 299: pp. 999-1000, 1978.

Cavenaugh, E.L, A method for determining costs associated with laboratory error, Am. J. Public Health, 71: pp. 831-834, 1981.

Cebul, R.D., J.C. Hershey, et al., Using multiple tests: series and parallel approaches, Clinics in Laboratory Medicine, 2, 4, pp. 871-890, 1982.

Cebul, R.D., A look at the chief complaints' revisited. Current obstacles and opportunities for decision analysis, Med. Decis. Making, 4, 3: pp. 271-283, 1984.

Clarke, R.M., Undergraduate education in the cost-effective use of laboratory and radiological investigations in clinical decision-making, Med. Educ., 15: pp. 17-25, 1981.

Cole, G.W., Biochemical test profiles and laboratory system design, Hum. Path., 11: pp. 424-435, 1980.

Connell, F.A, T.D.Koepsell, Measures of gain in certainty from a diagnostic test, Am. J. Epid, 121: pp. 744.753, 1985 . 
Connelly, D. B.Steele, Laboratory utilization, problems and solutions, Arch. Pathol. Lab. Med, 104 , pp. $58-63,1980$.

Conn, R.Bu, R.D. Alter, G.D. Lundberg, Identifying oosts of medical care. An essentiall step in allocating resources, JAMA, 253: pp. 1586-1589, 1985.

Conn, R.B., Clinical laboratories. Profit center, production industry or patienteare resource? N. EngL. J. Med. 298: pp: $422-428,1978$.

Cunnings, KM., KB. Frison, MJ. Long, G. Hyrnkiewich, "The effects of price information on plysicians" test-ordering behaviour, Medical Care, 20: pp. 293, 1982.

Daniels, M., S.A.Schroeder, Variation among physicians in use of laboratory tests. II Relation to clinical productivity and outcomes of care, Med. Care, 15: pp. 482-488, 1977.

Detry, J.M.R., A. Robert, R.J. Luwaert, M.F. Rousseau, Diagnostic value of computerized exercise testing in men without previous myocard infarction. A multivariate compartmentall and probabilistic approach, Eur. Heart J., 6: Pp. 227-238,1985.

Diamond, G.A., J.S. Forrester, Analysis of probability as an aid in the clinical diagnosis of coronary artery disease, New Eng. J. Med., 300: pp. 1350-1358, 1979.

Diamond, G.A., M. Hirsch, J.S. Forrester, H.M. Staniloff, Application of information theory to clinical diagnostic testing. The electrocardiographic stress test, Circ., 63: pp. 915-921, 1981.

Dix, D., Decision analysis, N. Engl. J, Med, 317, 6, pp. 387, 1987.

Dixon, R.H., J. Laszlo, Utilization of clinical chemistry services by medical house staff, Arch. Intern. Med., 134: pp. 1064-1068, 1974.

Dolan, J.G, D.R. Bordley, A.I. Mushlin, An evaluation of clinicians" subjective prior probability estimates, Med. Dec. Making, 6: pp. 216-223, 1986.

Dombal, F.T. de, D.J. Leaper et al., Human and computer aided diagnosis of abdominal pain: Further report with emphasis on performance of clinicians, Br. Med. Journal, 1, pp. 376-380, 1974

Doubilet, P. and P.G. Herman, Interpretation of radiographs: effect of clinical history A.J.R, 137, pp. 1055-1$058,1981$.

Doubillet, P., A mathematical approach to imterpretation and selection of diagnostic tests, Med. Dec. Making, 3: pp.177-195, 1983.

Dresnick, S.J. W.I. Roth, B.S. Linn, T.C. Pratt, A. Bluni, The physicians " role in the cost containment problem, JAMA, :241, 1979.

Drummond, M.F., Principles of economic appraisal in health care, Oxford University press ${ }_{n}$ New York, 1980.

Drummond, M. Methods for the economic evaluation of bealth care programmes, Oxford Universilty Press, 1987.

Durbridge, T.C., R.G. Edwards, The validity of screening, Uit: Benson, E.S. et al., 1978.

Eeckhoudt, L., T. Lebrun, J.C. Sailly, Risk aversion and physicians' medical decision-making, J. Healih Econ, 4: pp. 273-281, 1985 .

Eeckhoudt, La, J. Melin, R. Vanbutsele, J.C. Sailly, A. Robertson, An information theory approach to the diagnosis of the presence and severity of coronary artery disease, Meth. Inform. Med., 24: pp. $141-148,1985$.

Eeckhoudt, L.R., T.C. Lebrun, J.C. Sailly, The informative content of diagnostic tests: an economic analysis, Soc. Sc. Med., 18: pp. 873-880, 1984. 
Egan. J.P., signal detection theory and ROC analysis, Academic Press, New York, San Francisco, London, 1975 .

Eijden van der; A.P.J., Budgettose, de zjekenhuisziekte, Medisch Contact, 21: pp. 661-662, 22 mei 1987.

Eisenberg, J.M., J.C. Hershey, Derived tresholds. Determining the diagnostic probabilities at which clinicians initiate testing and treatment, Med. Dec. Making, 3: pp. 155-167,1983.

Eisenberg, JM, An Educational Program to Modify Laboratory Use by House Staff, J. Med. Educ, 52: pp. $578-581,1977$.

Essenberg, JM, S.V. Williams, L. Garner, R. Viale, H. Smits, Computer-based audit to detect and correct over utilization of laboratory tests, Med. Care; 15: pp. 915-921, 1977.

Elsenberg J.M, S.V. Williams, Cost containment and changing physicians' practice behawior, JAMA, 246: pp. 2195-2201, 1981.

Elstein, E.S. L.S. Shulman, S.A. Sprafka, Medical problem solving. An analysis of clinical reasoning, Harvard Uniwersity Press, Cambridge, 1978.

Epstein, S.E., KM. Kent, R.E. Goldstein, J.S. Borer and D.R. Rosing, Strategy for evaluation and surgical treatment of the asymptomatic or mildly symptomatic patient with coronary artery disease, American Journal of Cardiology, 43, pp. 1015-1025, 1979.

Evans, R.G. Strained mercy. The economics of Canadian health care, Butterworth, Toronto, 1984.

Bveren, G.D., Impact of supervision by medical teachers and in-patient test control programmes on the out-patient test utilization of residents, Med. Educ 19: pp. 138-142, 1985.

Everett, G.D., C.S. deBlois, P.F. Chang, T. Holets, Effect of cost education, cost audits and faculty chart review on the use of laboratory services, Arch. Intern. Med., 143: pp. 942-944, 1983.

Feldman, M:S, JiG. March, Information in organisations as signal and symbol, Adm. Sc. Quart., 26: pp. $171-186,1981$.

Feldstein, M.S, B. Friedman and H.S. Luft, Distributional aspects of national health insurance benefits and finance, National Tax Journal, 25, 4, pp. 497-510, 1972.

Fineberg, HV, L.A. Pearlman, Low-cost medical practices, Ann. Rev: Public Health, 3: pp. 225-248, 1982.

Flnkelstein, N.S., Redueing the use of the clinical laboratory: How much can be saved Uit: Connelly, D.P. et $\mathrm{al}_{,}, 1982$.

Finkelstein, N.S., Technological change and laboratory test volume, Uit: Benson, E.S. et al., 1978.

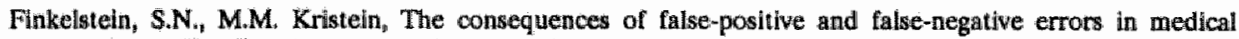
diagnosls; Clin. Lab, Med., 2: pp. 779.787, 1982.

Finkelstein, $S . N$. An approach to studying the cost behavior of changing utilization of a hospital laboratory, Hum. Path, 11: pp. 435-439, 1980.

Fowkes, F.G.R., Containing the use of diagnostic tests, Br. Med: J., 290: pp. 488-489, 1985.

Freeborn, D.K, D. Baer, M.R. Greentick, I.W. Bailey, Determinants of medical care utilization: physicians" use of laboratory services, A.J.P.H., 62* pp. 846-853, 1972.

Freund, $\mathrm{D}$. A, Competitive health plans and alternative payment arrangements for physicians in the United States: public sector, Health Policy, 7, pp. 163-173, 1987. 
Frowein; $\mathrm{C}, \mathrm{F}$ R. Hindriks, A, Bosman, H. Kamps, Kostprijsterekening van klinisch chemisch onderzoek met behulp van een algemeen toepasbaar kostenstructuturmodel, $T$. Ned. Ver, Klin. Chem, 10: pp. $181-188,1985$.

Gaerdenfors, P. and N. Sahlin, Decision, probability and utility: selected readings, Cambridge Univensity Press, 1988.

Gallen, R.S. S.R. Gambino, Beyond normality:the predictieve value and efificiency of medical diagnoses, John Wiley and Sonis, New York, 1975.

Gerritsma, J.G.M., J.A. Smal, De werkwijze van de huisarts en internist, Medisch Contact, 5. pp. 1663-1664, 24 dec 1982

Gezondheidsraad, Grenzen van de gezondheidszorg, Staitsuitgeverij Den Hagg, no. 29, 1986.

Gorry, G.A., Decision analysis: principles for clinical application, Uit: Benson, E.S. et all, 1978.

Greenes, R.A. K.C. Cain and C.B. Bigg, Patient-oriented performance measures of diagnostic tests, Med. Dec. Making, 4, pp. $7-46,1984$.

Griner, P.F, The impact of education on patterns of laboratory utilization in the teaching hospital, Uit: Benson, $\mathbb{E}$ S. et al, 1978.

Griner, P.F., R.J. Mayiewski, A.I. Mushlin, P. Greenland, Selection and interpretation of diagnostic tests and procedures, Principles and applications, Ann. Intern. Med., 94: pp. 553-600, 1981.

Griner, P.F. Use of the laboratory tests in teaching hospital. Long-term trends. Reductions in use and relative cost, Ann, Intern. Med, 90 : pp. 243-248, 1978.

Grivell, AR., HJ. Forgie, C.G. Fraser; MN. Berry, Effect of feedback to clinical staff of information on clinical biochemistry requesting patterns, Clin. Chem., 27: pp. 1717-1720, 1981.

Groot, L.MJ Incentives for cost-effective behavior: a Dutch experience, Health Policy, 7, pp $175-188,1987$.

Groot, LM. M., Patient-georienteerde ziekenhuiseconomie; een poging tot synthese lussen professie en management, Stolte, 1978.

Groot, L.M.J. en C. Visinescu, Medische technologie, wetgeving, beleid en kosten in Nederiand, 1982.

Grossman, R.M., A review of physician cost-containment strategies for laboratory testing, Med. Care, 21: pp. $783-802,1983$.

Gross, $\mathrm{R}_{\text {, }}$ Was ist eine gesicherte Grundlage fur therapeutische Entscheidungen? Arch, Chir, 364, 1984.

Hanley, JA and $B J$ McNeil, The meaning and use of the area under a recelver operating characteristic (ROC) curve, Dirga. Radiol, 143, pp. 29-36, 1982.

Hardwick, DF, J.I. Morrison, J. Tydeman, P.A. Cassidy, Laboratory costs and utilizatlon; a lramework for

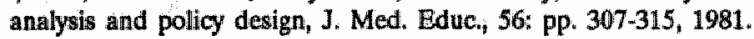

Hardwick, D.F. J.I. Morrison; J. Tydeman, P.A. Cassidy, Structuring complexity of testing: a process oriented approach to, limiting unnecessary laboratory use, Am. J. Med. Technol, 48: pp. 605-608, 1982.

Harris Jr, J.M., The hazards of bedside Bayes, JAMA, 246: pp $2602-2605,1981$.

Hartz, AJ., An alternative to sensitivity and speciflcity in comparing the utility of a laboratory west, Arch. Pathol. Lab. Med, 108, pp. 65-67, 1984.

Hartz, A, R. Centor, Measures of the walue of a dignostic test derived firom stochastic thresholds, Med. Dec. Making; 6: pp: 149-153, 1986 . 
Helm, HJ, wan der en E.AH. Hische, De evaluatie wan diagnostische technologieen, Medisch Contact, 9, pp. $273-278,1986$.

Hermann, O.A., H.T. Sugiura, Walidity and bias in laboratory tests [letter], Arch. Pathol. Lab. Med.s 108: pp.769-771, 1984.

Hersthey, J.C, R.D. Cebul; S.W. Willfams, Clinical guidelines for using two dichotomous tests, Med. Dec. Making, 6, 2, pp. 69-78, 1986 .

Hjelm, Mr, Evaluation in clinical llaboratory services, Holland, W.W, 1983.

Holmes, M.M. D.R. Rowner, A.S. Elstein, G.B. Holzman, Factors affecting laboratory utilization in clinical practice, Med. Decis. Making; 2: pp. $471-482,1982$.

Horwath, B., J. Pecci, W. Gay, Feswer tests may cost more[letter], N. Bngl. J. Med., 312: pp. 1645-1646, 1985.

Hughes, R.A., P.M. Gertman, J.J. Anderson, N.L Friedman, The Ancillary Services Review Program in Massachusetts. Experience of the 1982 pilot project, JAMA, 252: pp. 1727-1732,1984.

Joly, J.G. La rationalisation des couts de laboratorie; l'importance du leadershipp medical eclaire, Union Med. Can., 111: pp. 167-172, 1982.

Jones-Lee, M., The walue of life, Martin Robertson, 1976.

Kahneman, D., A. Tversky, Judgement under uncertainty. Heuristics and biases, Sciences, 185: pp. 1124-1131, 1974.

Kassebaum, D.G., Teaching laboratory test use [editorial], J. Med. Educ., 60: pp. 420-421, 1985.

Kassirer, J.P., The clinical decision-making process, Uit: Connelly, D.P. et al., 1982.

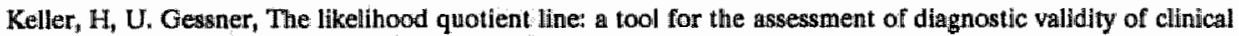
chemical tests, J. Clin. Chem. Clin. Biochem., 19: pp. 1211, 1981.

KJatt, E.C, E.S. Wasef, E.T. Wong, Creatine kinase in a biochemical test panel: the high cost of a seemingly inexpensive test, Am. J. Clin. Pathol., 77: pp. 280-284, 1982.

Klein, L., P. Charache and R. Johannes, Effect of physicians' tutorials on prescribing patterns and drug cost in ambulatory patients, Clin. Res, 28, : pp. 296, 1980.

Knottnerus, A, Interpretatie van diagnostische gegevens: theoretische en praktische bijdragen aan de diagnostische epidemiologie in de extramuralle gezondheidszorg, Rijksuniversiteil Limburg, Masastricht, 1986 .

Komariff, A.L. T.M. Pass, H. Sherman, Improved clinical strategies for the management of common problems, Uit: Connelly, D.P. et alle, 1982.

Kong, A, O.O. Barnett, F. Mosteller, C. Youtz, How medical professionals evaluate expressions of probability, New Eng. J. Med., 315: pp. 740-744, 1986.

Koning, A, A. Ament, A graphical method for minimizing the ratio of expected costs and expected returns of medical tests, Internal report, Vakgroep Medische Informatica en Statistiek, RL, 1988.

Kralewski, J.E., B. Dowd; R, Feldman and J. Shapiro, The physician rebellion, N. Engl J. Med, 316, 6, pp. 339-341, 1987.

Kreeke, A.P. van der, VNZ wil meer efficlency liboratoria, Inzet, 1, pp. 12-13, 1988.

Lawrence, R.S., The rolle of physician education in cost control, Carels. E.J. et al., 1980.

Leaf, A. The doctor's dilemma and society's too, The New England Journal of Medicine, 310, pp. 718-721, 1984. 
Lehmann, C., A. Leiken, Cost of laboratory ordering strategies, Lab. Med, 15: pp. 759-760, 1984.

Leijten, J.F., Laboratoriumonderzoek: de wet van de verminderde meerwaarde, Ament, A, L. Bedaux $R$. Mercx, T. Vissers, 1985.

Leijten, J.F., F.van der Geer, M.N. Scholten, H.M. Goldschm, The costing of tests in a laboratory for clinical chemistry an haematology, Ann. Clin. Biochem. 21: pp. 109-115, 1984.

Levinsky, N.G., The doctors' master, The New England Journal of Medicine, 311, pp. 1573-1575, 1984.

Linn, L.S J. J. Yager, B.D. Leake, G. Gastaldo, C. Palkowski, Differences in the number and costs of tests ordered by internists, family, physicians, and psychiatrists, Inquiry, 21: pp. 266-275, 1984.

Long, M.J., K.M. Cummings, K.B. Frisof, The role of perceived price in physicians' demand for diagnostic tests, Med. Care, 21: pp. 243-250, 1983.

L.S.V. De specialist van morgen. Een toekomstvisie in antwoord op de problematiek van vandaag, Utrecht, 1987.

Lusted, L.B., Observer error, signal detectability and medical decision-making Jacques, J.E.C.C. Thomas, 1972.

Lusted, L.B., General problems in medical decision making with comments on. ROC Analysis, Sem. Nucl. Med., 8: pp. 299-306, 1978.

Lyle, C.B., R.F. Bionchi, J.H. Harris at al, Teaching cast containment to house officers at Charlotte Memorial Hospital, J. Med. Educ., 54: pp. 856-862, 1979.

Maarse, J.A.M., Budgettering van ziekenhuizen, Inaugurele rede, RL, Maastricht, 22 april 1988.

Markel, S.F., J.R. Mitchell, Modes of compensation of pathologists and the charges for and use of laboratory services, JAMA, 243: pp. 2053-2055, 1980.

Martin, A.R., M.A. Wolf, L.A Thibodeau, V. Dzau, E. Braunwal, A trial of two strategiles to modify the test-ordening behavior of medical residents, New Eng. J. Med., 303: pp. 1330-1336, 1980.

Martin, S.P., M.C. Donaldson, C.D. London, O.L. Peterson, Inputs into coronary care during 30 years:a cost-effectiveness study, Ann. Intern. Med, 81: pp. 289-293, 1974.

Maynard, A, Incentives for cost-effective physician behaviour, Health Policy, 7, pp. 189-204, 1987.

McComnell, T.H., C.T. Ashworth, R.D. Ashworth, C.R. Nielsen, Algorithm-derived computergenerated interpretive comments in the reporting of laboratory tests, Am. J. Clin. Path., 72: pp. 32-41, 1979.

McDonald, J., Protocol-based computer reminders, the quality of care and the non-perfectabillty of man, N. Engl. J. Med., 295, pp. 1351-1355, 1976.

McNeil, B.J., Decision making in radiology: ROC curves, Connelly, D.P., E.S. Benson, M.D. Burke, D. Fenderson, 1982.

McNeil, B.J., E.G. Cravalho, Critical issues in medical technology, Auburn House Publishing Company, Boston Massachusetts, 1982

McNeil, B.J., S.G. Pauker, Incorporation of patient walues in medical decision making, McNeil, B.J, E.G. Cravalho, 1982.

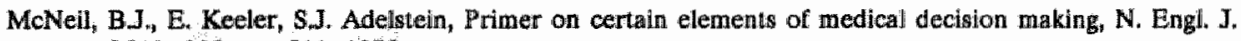
Med., 293: pp. 211, 1975.

Metz, C.A, Basic principles of ROC analysis, Semin. Nucl. Med., 8: pp. 283, 1978. 
Metz, CM, DJ. Goodenonghm, $\mathrm{K}$ Kosman, Evaluation of receiver operating characteristic curve data tin terms of information theory with applications in radiography, Diagn. Radiol. 10, pp. 297-305, 1973 .

Milemain, P.A. J. Bowma et ally Hex remen van behandelingsbeslissingen met behulp van bilewing röntgenfoto's door Nederlanidie tandartsen, Ned. Tijdschr. Tandh, 93, Pp. 368-373, 1986.

Miller, M.C, M.C. Westphal, JR, Reigart, Mathematical models in medical dignosis, Praeger, 1981.

Mintzberg, $H_{*}$, The structuring of organizations, Englewood Cliffs, 1979.

Moloney, T.W. D.E, Rogers, Medical technology - different view of the contentious debate over costs, N. Engl. M, Med, 301: pp. 1413-1418, 1979.

Murphy, 1, J.B. Henry, Effective utilization of clinilcall laboratories, Hum. Pathol, 9: pp. 625-633, 1978,

Mushikin, $\boldsymbol{S}_{*}, L_{\text {. }}$ Datta, $\mathbf{R}$. Perloff, New health technologles: assessing the costs and benefits improwing evaluation, Sage Publlications, : pp, 192-207, 1979 .

Myers, L.P. and S.A. Schroeder, Physician use of services for the hospitalized patient: a neview with implications for cost containment, Milbank Memorial Fund Qwartierly, 59(4),pp. 481-507, 1981.

Nationaal Ziekenhuis Instituut, Produktie-statistiek, Utrecht, 1988.

Neufeld, V.R., G.R. Norman, Assessing clinical competence, Springer publishing company, New York, 1985.

Neuhauser, D., Stimulating costi-effective behawhour in hospitals, Health Policy, $7(2)$, pp. $205-213,1987$.

Neuhauser, D., The redly effective health service delivery system; Health Care Management Review, 1, Pp." $2532,1976$.

Neuhauser, D. and D. Levickd, Whiat do we gain from the sixth stool guialc?, W.E.J.M, Pp. 226, 1975.

Nolan, J.P., N.J. Tarsa, G. DiBenedetto, Case-finding for unsuspected thyroid disease" costs and health benefits, Am. J. Clin. Pathol, 83. pp. 346-355, 1985.

Pauker, S.G., J.P. Kassirer, Decision analysis, N. Engl. J. Med., 316, 5, pp. 250-258, 1987.

Pauker, S.G., J.P. Kassirer, Therapeutic decision making: cost-benefit anallysis, N. Engl. J. Med., 293: pp. $229-234,1975$.

Pauker, S.G., J.P. Kassirer, The treshold approach to clinical decision making, N. Engl. J. Med, 302: pp. $1109-1117,1980$

Pellegrino, E. O, Medical morality and medical economics, Hastings Center Report, 9, pp. 8-11, 1978.

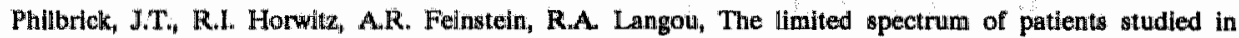
exercise test research. Analyzing the tip of the lceberg, JAMA, 248: pp. 2467-2470, 1982.

Pineault, $\mathrm{R}$, The effect of medical training factors on plyysician utilization behavior, Med. Care, 15; pp. 51-67, 1977.

Politser, $\mathbf{P}$, Reliablitity, decision rules and the value of repeated tests, Med. Decis. Making, 2; pp. 47-69, 1982.

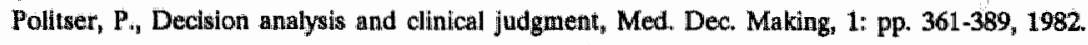

Prins, J.M, D.Th. Ubbink, J C Netelenbos, Het rendement van routinebepalingen bij opname in een kliniek woor inwendige geneskinde, Ned. Tydach. Geneeskd, 129; pp. 2403-2406, 1985.

Ransohof, D.F, A.R. Feinstein, Is decision analysis useful in clinical medicine?, Yale J. Biol. Med., 49; pp. 165168,1976 . 
Ransohoff, D.F., AR. Feinstein, Problems of spectrum and bias in evaluating the efficacy of diagnostic tests, N. Engl. J. Med, 299, 17, pp. 926-930, 1978.

Rao, KM, S.L. Bordine, D.F. Keren, Decision making by pathologists. A strateg for curtailing the number of inappropriate tests, Arch. Pathol. Lab. Med, 106: pp. 55-56, 1982.

Reagan, M.D., Physicians as gatekeepers; N. Engl. J. Med., 317, pp. 1731-1734, 1987.

Reit, C, H.G. Groendahi, Application of statistical decision theory to radiographic diagnosis of endodontically treated teeth, Scand. J. Dent. Res., 91: pp. 213-216, 1983.

Relman, A.S., Cost control, doctor's ethics and patient care, Issues in Science and Technology, 1, pp. 103-111, 1985.

Reuben, D.B., Learning diagnostic restraint, N. Eingl. J. Med., 310: pp. 591-593, 1984.

Rhyne, R.Lin, S.H. Gehlbach, Effects of an educational feedback strategy on physician utilization of thyroid function panels, J. Fam. Pract., 8: pp. 1003-1007, 1979.

Roberts, C.Jl, Evaluation of diagnostic services, Holland, w, p..

Robertson, W.O., Costs of diagnostic tests: estimates by health professionals, Medical Care, 18: pp. 556-559, 1980.

Sackett, D.L., Laboratory screening:a critique, Fed. Proc, 34: pp. 2157-2161, 1975.

Sappenfield, R.W., D.A Boudreau, P.G. Cartrou, M.F. Beeler, Ranking diagnostic protocols- a proposed process based on use of the nine-cell diagnostic decision matrix, Am. J. Clin. Pathol, 76: pp. 127-132, 1981.

Schaaf, J.H., Budgettering in ziekenhuizen, Medisch Contact, 2, pp. 41-44, 1984.

Schroeder, S.A., K. Kenders, J. Cooper, T. Plemme, Use of laboratory tests and pharmaceuticals- wariation among;physicians and the effect of a cost audit on subsequent use, JAMA, 225: pp. 969-973, 1973.

Schroeder, S.A.; L.P. Meyers et al, Educating physicians as a hospital cost containment strategy costs more than it saves, Clin. Research, 31(2): pp. A304-A304, 1983.

Schroeder, S.A, Variations in physician pratice patterns: a review of medical cost implications, Carels, E.J. et al., 1980.

Schroeder, S.A. and J.A. Showstack, Financial incentives to perform medical procedures and laboratory testi: illustrative models of office practice, Medical Care $16, \mathrm{pp} .289,1978$.

Schroeder, S.A.; L.P. Meyers et al, The failure of physician education as a cost containment strategy, JAMA, 252: pp. 225-230, 1984 .

Schroeder, S.A. D.S. O'Leary, Differences in laboratory use and length of stay between university and community hospitals, J. Med. Ed., 52:" Pp. 418-420, 1977.

Schwartz, W.B., Decision analysis. A look at the chlef complaints, N. Engl. J. Med., 300: pp. 556-559, 1979.

Schweitzer, S.O., Cost-effectiveness of early detection of disease, Health Services Research, pp. 22-32, Spring 1974.

Scitovsky, Aand N. MoCall, Changes in the costs of treatment of selected illnessed, Pallo Alto Medical Research Foundation, Palo Alto, 1975:

Scott, W.R, Making professional work: three models of control for health organizations, Health Serv. Resi, Pp. , 1982 . 
Shannon, $C . E$ W. Weaver, The aha hematical theory of communication, Universing of llinois Press, Urbana Chicago, London, 1972 .

Sheeley, D.R., H. Sherman Conservation un hospital resource use: treatment of preumonias: an unvestigation of care in four hospituls ower the past decadle, Ann. mitern. Med., 85: pp. 648-652, 1976.

Shel don, A. Managing doctors, Dow Jones, Homewood, Ilinais, 1986,

Sheps, SB, MT. Schechter, The assessment of diagnostic tests, IAMA, 252; pp. 2418-2422, 1984.

Sherman, A, Behaviour modification theory and practice, Monterey, Califorma, 1973 .

Shonter, B* Bedside Manners; Simon \& Schuster, New York, 1985.

Showstack, J.A., S.A. Schroeder, M.F. Matsumo, Changes in the use of medical technologies, 1972-1977: a study of 10 inpatient diagnoses, $\mathrm{N}$. Engl. J. Med., 306: pp. 706-712, 1982.

Skipper, J.K, G. Smith, J.1. Muliligan, M. Garg, Physicjans' knowledge of cost: the case of diagnostic tests, Inquiry, XIII: pp. 194-198, 1976.

Sol, J.C.A., F.C.J, Stevens, J. Schepers, E.H.M. Snijders en L.M.J, Groot, Een onderzoek naar

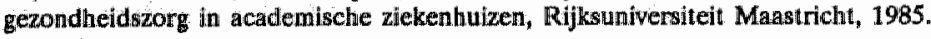

Somers, A.R., H.M. Somers, A proposed framework for health and health care policies, Inquiry, 4, 2: pp. 115-171, 1977 .

Sondik, E.J., Clinical evaluation of test strategles. A decision analysis of parameter estimation, Clin. Lab. Med., 2: pp, 821-833, 1982.

Sox, H.C, Decision analysis: a basic clinical skill ?, N. Engl. J. Med., 316, 3, pp. 271-272, 1987m

Spiegel, C.T., B.A. Kemp, M.A. Newman, P.S. Bimbaum, C.L. Al, Modification of deciston-making behavior of third-year medical students, J. Med. Educ, 57: pp. 769-777, 1982 .

Stefanu, C. R.G. Newman, M.L. Pate, M.B. Chassie, R.J. Ander, Severity of patients'illiness: an important factor contributing to laboratory costs in a teaching hospital, J. Med. Educ., 59: pp. 598-600, 1984.

Stilwell, J.A., Costs of a clinical chemistry \#aboratory, J. Clin. Pathol., 34: pp. 589-594, 1981.

Stuwell, J.A, D. Young, A Cunnington; Evaluation of laboratory tests in hospitals, Ann. Clin.. Biochem., 17* p. $281-286,1980$.

Stolte, In het ktder van de gezondtheidszorg, Tijdstroom, Lowhem, 1978.

Sturnans, F, Epidemiologie, Theorie, methoden en toepassing, Dekker en van de Vegt, Nijmegen, 1986.

Swets, J.A., R.M. Pickett, Ewaluation of diagnostic methods. Methods from signal detection theory Academic Prass, New York, 1982.

Thompson, M., Decision analysis for program evaluation, Sage Publ, Beverly Hills, 1982.

Thompson, M., Benefit-cost analysis for program evaluation, Sage Publ., Beverly Hills, 1980.

Thurow, L..., Medicine versus economics, N. Engl. J. Med., 313, pp. 611-614, 1985.

Therticy, W.M., J. Fitagerald, R. McHenry, B.J. Roth, B. Psaty, Physicians' estimates of the probability of myocardial infarction in emergency room patients with chest pain, Med. Dec. Making, 6: pp. 12/17, 1986 .

Torrance, G.W., Measurement of health state utilities for economic apptaisal: A review; Journal of Health Economiles, 5, 1, pp. 1-30, 1986. 
Tydeman, J, J.L. Morrison, P.A. Cassidy, D.F. Hardwick, Analyzing the factors contributing to rising laboratory costs, Arch. Pathol. Lab. Med., 107; pp. 7-112, 1983.

$\mathrm{Ulm}_{n} \mathrm{~K}, \mathrm{E}$. Sauer, H. Sebening, Evaluation of non-invasive examinations of coronary artery disease using information theory, Methods Inf. Med., 20; pp. 213-216, 1981.

Vries, T. de., Het klinisch-chemisch laboratorium in econonisch perspectief, Stenfert Kroese, Laiden, 1974.

Vries, T, de., Rationeel gebrilk wan het ziekenhuislaboratorium door artsen, Gezondheidsraad/WHO, 1988.

Vries, T. de, Rational and irrational use of ancilliary services, Paper Dubrovnik Technolygy in the health care system, sept. 2 nd. 1988.

Warner, K.E., B.R. Luce, Cost-benefit and cost-effectiveness analysis in health care. Principles, practice and potential, Health Administration Press, Ann Arbor, Michigan, 1982.

Weinstein, M.C. and H.V. Fineberg, Clinical decision analysis, W.B. Saunders $\mathrm{CO}_{\text {" }}$ Philadelphia, 1980 .

Weinstein, M.C., Economic assessments of medical practices and technologies, Med. Decis. Making 1 : pp. 309-330, 1981.

Werner, M., Will abstract models change the practice of medi- cine 7, Benson, E.S., M. Rubin, 1978.

Werner, M., C.H. Altshuler, Cost effectiveness of multiphasic screening: old controversies and a new rationale, Hum. Pathol. 12: pp. 111-117, 1981.

Wertman, B.G., S.V. Sastrin, Z. Pavlova, G.D. Lundberg, Why do physicians order laboratory tests?, JAMA, 243: pp. 2080-2082, 1980.

Wheeler, L.A., G. Brechner and L.B. Sheiner, Clinical laboratory use in the evaluation of anemia, JAMA, 238, pp. 2709-2714, 1977.

Wickings, I., Combining clinical budgets and DRG's for quality management, Health Policy, 7, pp. 21.5-226, 1987.

Wickings, I., J. Coles, The ethical imperative of clinical budgeting, Nuffield/York Portfolios, 10" pp. 1-8, 1984.

Wilms, P.J.M., Op waarde geschat. Methoden en technieken ter bepaling wan de consumentenwaardering van gesubsdidieerde voorzieningen, Instituut voor Onderzoek van Overheidsuitgaven, Den Haag, 1984.

Winkelman, J.W., R.B. Hill, Clinical laboratory responses to reduced funding, JAMA, 25: pp. 2435-2440, 1984.

Winkel, $\mathbb{P}$., B.E. Statland, Assessing cost savings when unnecessary utilization of laboratory tests can be abolished, Am. J. Clin. Pathol, 82: pp. 418-423, 1984.

Winkenwerder, W. and J.R. Ball, Transformation of american health care. The role of the medical profession, N. Engl. J. Med, 318, 5, pp. 317-319, 1988.

Wong, E.T., T.L. Lincoln, Ready! Fire !...Aim! An inquiry into laboratory test ordering, JAMA, 250: pp. $2510-2513_{1} 1983$.

Wong, E.T., M.M. McCarron, S.T. Shaw jr., Ordering of laboratory tests in a teaching hospital. Can it be improved 7, JAMA, 249: pp. 3076-3080, 1983.

Wright, HJ., D.B. MacAdam, Diagnost iek en besluitworming. Rationele argumenten in de geneeskunde, Bohn, Scheltema en Holkema, Utrecht, Antwerpen, 1982.

Wulff, H.R., Principes van klinische denken en handelen, Bohn, Scheltema en Holkema, Utrecht, Antwerpen, 1982 . 
Young, D.S, The role of the laboratory in clinical decision making, Connelly, D.P., E.S. Benson, M.D. Burke, D. Fenderson, 1982.

Young, MJ, R.M. Poses, Can physicians be rational about diagnostic tests ?, Clin. Lab. Med., 4: pp. 25-39, 1984. 


\section{LIJST VAN FIGUREN}

Figuur 1.1. Overzicht van het gebruik van tests en medische acties: een

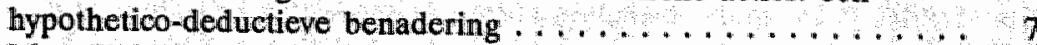

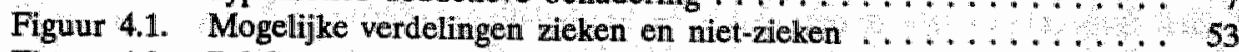

Figur 4.2 , ROC-curve $\ldots \ldots \ldots \ldots \ldots \ldots \ldots \ldots \ldots \ldots \ldots$

Figur 4.3. Onzekerheidsreductie bij positieve en negatieve testuitslagen (Connell \& Koepsell, 1985) . . . . . . . . . . . . . . 58

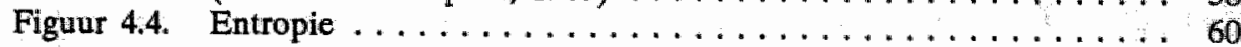

Figuren $4.5 \mathrm{a}$ en $4.5 \mathrm{~b}$. Vergelijking $\mathrm{W}$ en $\mathrm{H}_{\mathrm{m}} \ldots \ldots \ldots \ldots \ldots$

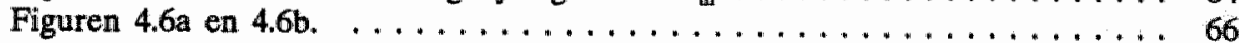

Figuur 5.1. Hm als percentage van maximal te behalen aantal bits . . . . . 75

Figuur 5.2. Kosten per bit (Him) (logaritmisch) $\ldots \ldots \ldots \ldots \ldots \ldots$

Figuur 5.3. Kosten per opbrengst (W) (logaritmisch) $\ldots \ldots \ldots \ldots \ldots$

Figuur 5.4. Kosten per bit naar kostenverhouding test $\mathbf{A}$ en $\mathbf{B} \ldots \ldots \ldots \ldots$

Figuur 5.6. Optimale teststrategie bij willekeurige kosten-ver-houding en

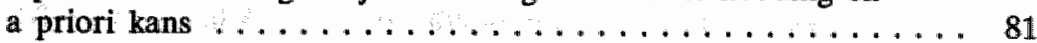

Figuur 6.1. Verdeling zieken en niet-zieken $\ldots \ldots \ldots \ldots \ldots$

Figuur 6.2. Kosten (TK) en Opbrengsten (TO) en Winst (TW) . . . . . . . 96

Figuur 6.3. Optimale afkappunten bij zes modelspecificaties $(p=.5) \ldots \ldots$.05

Figuur 6.4. Optimale sensitiviteit bij zes modelspecificaties naar prevalentie . 106

Figuur 6.5. Optimaal afkappunt $\mathrm{K} / \mathrm{O}$ criterium grafisch bepaald . . . . . . . 108

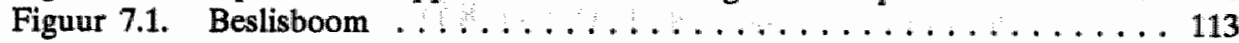

Figuur 7.2. Verwachtingswaarden strategieën gegewen a priori kans. . . . . 115

Figuur 7.3. Incrementele opbrengst van perfecte informatie $W(\mathbb{P})$ en test

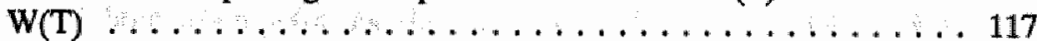

Figuur 7.4. Combinaties van sensitiviteit en specificiteit waarvoor geldt

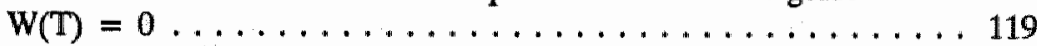

Figuur 7.5. Combinatie van $\mathrm{Se}$ en $\mathrm{Sp}$ met voorwaarde $\mathrm{W}(\mathrm{t})=0 \ldots \ldots \ldots \ldots$

Figuren 7.6a en 7.6b. Waarde van tests bij verschillende a priori kansen , 123

Figuur 7.7. Verwachtingswaarden teststrategie met drie afkappunten . . . . 126

Figuur 7.8. Incrementele opbrengst van een continue test $\ldots \ldots \ldots \ldots \ldots$

Figuur 7.9. Incrementele opbrengst inspannings-ECG (W(T)) en angiogram

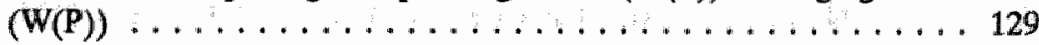

Figuur 7.10. Incrementele waarden van inspannings-ECG (drie afkappunten) . 130

Figuur 7.11. Tweeweg-gevoeligheidsanalyse met betrekking tot $\mathrm{M}$ en $\mathrm{p} \ldots \ldots$. . 131

Figuur 7.12. Optimale strategie naar $\mathrm{M}$ en $\mathrm{p}$ (criterium $\mathrm{O} . \mathrm{K}$ ) $\ldots \ldots \ldots \ldots, \ldots, \ldots$

Figuur 7.13. $\mathrm{O} / \mathrm{K}$ van het inspannings-ECG $(\mathrm{T})$ en het angiogram $(\mathrm{A}) \ldots \ldots 133$

Figuur 7.14. Optimale strategie neer $\mathrm{M}$ en $\mathrm{p}$ (K/O-criterium) . . . . . . . . . 134

Figuur 8.1. ROC-curves plus "geprojecteerde" conjunctieve en disjunctieve

ROC-curves . . . . . . . . . . . . . . . . . . . . . 142

Figuren $8.2 \mathrm{a}$ en $8.2 \mathrm{~b}$ Conjunctieve en disjunctieve geprojecteerde ROC-

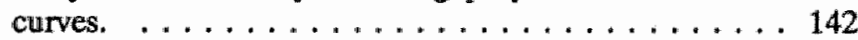

Figuur 8.3. Verzameling aantal zieken . . . . . . . . . . . . . . . . . 144

Figuur 8.4. Se en $\mathrm{Sp}$ van combinaties van afhankelijke tests. . . . . . . . . 146

Figuur 8.5. Basismodel O-K . . . . . . . . . . . . . . . . . . . 150

Figuur 8.6. "Geprojecteerde" ROC-curves, disjunctieve combinaties plus optimale combinaties (criterium O-K) ............152

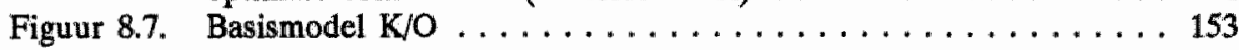


Figuur 8.8. Optimale strategieën met betrekking tot opsporing borstkanker

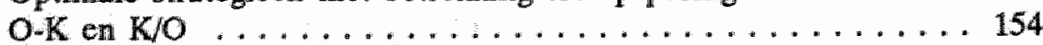

Figuur 8.9. Gevoeligheidsanalyse QALY, criterium $\mathrm{O}-\mathrm{K} \ldots \ldots \ldots \ldots \ldots 155$

Figuur 8,10. Gevoeligheidsanalyse kosten behandeling, criterium $\mathrm{O}-\mathrm{K} \ldots \ldots 157$

Figuur 8.11. Gevoeligheidsanalyse kosten behandeling, criterium $\mathrm{K} / \mathrm{O} \ldots \ldots 158$

Figuur 8.12. Gevoeligheidsanalyse $U_{2}$, criterium $\mathrm{O}-\mathrm{K} \ldots \ldots \ldots \ldots \ldots \ldots$

Figuur 8.13. Gevoeligheidsanalyse kosten US, criterium $\mathrm{O}-\mathrm{K} \ldots \ldots \ldots \ldots 160$

Figuur 8.14, Gevoeligheidsanalyse kosten US, criterium KJO .......... 161

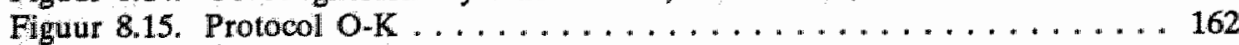

Figuur 8.16. Protocol K/O . . . . . . . . . . . . . . . 163

\section{LIJST VAN TABELLEN}

Tabel 2.1. Percentage toename ten opzichte van de voorgaande jaren van röntgen- en laboratoriumonderzoek naar kliniek en polikliniek

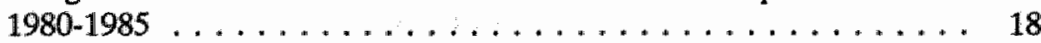

Tabel $4.1 . \quad 2 \times 2$-tabel . . . . . . . . . . . . . . . . . . . . 48

Tabel 5.1. Sensitiviteit en specificiteit en opbrengst in $H_{m}$ en $W$ van de

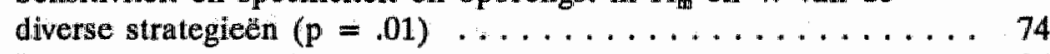

Tabel 6.1. Kosten en opbrengsten van een test $\ldots \ldots \ldots \ldots \ldots \ldots \ldots 86$

Tabel 6.2. Optimalisering volgens criteria $\mathrm{O}-\mathrm{K}$ en $\mathrm{K} / \mathrm{O} \ldots \ldots \ldots . \ldots . . . .97$

Tabel 6.3. Incrementele kosten- en opbrengstengegevens: een fictief rekenvoorbeeld . . . . . . . . . . . . . . . 104

Tabel 6.4. Sensitiviteit behorende bij optimaal afkappunt, model 6 naar waarde van een QALY (10.000 tot 50.000) en naar a priori kans . . . . . . . . . . . . . . . . . . . . . . . . 107

Tabel 6.5. Opbrengsten en kosten bij twee optimaliseringscriteria . . . . . 108

Tabel 7.1. Waarde van een test bij verschillende a priori kansen $\ldots \ldots \ldots 123$

Tabel 7.2. Sensitiviteit en specificiteit bij verschillende afkappunten inspannings-ECG . . . . . . . . . . . . . . . . . 127

Tabel 8.1. Cijfervoorbeeld combinatie twee onafhankelijke tests . . . . . . 141

Tabel 8.2. Geschatte sensitiviteit en specificiteit van CT en US (Alderson e.a., 1983) . . . . . . . . . . . . . . . . . . . . . 148

Tabel 8.3. Optimale afkappunten binnen strategie $6 \ldots \ldots \ldots \ldots \ldots \ldots 15$

Tábel 8.4. Kosten en opbrengsten bij drie protocollen . . . . . . . . . . . 164

Tabel 8.5. Incrementele kosten/incrementele opbrengsten bij drie protocollen ......................... 164

Tabel 8.6. Verband tussen optimalisering volgens criteria $\mathrm{O}-\mathrm{K}$ en $\mathrm{K} / \mathrm{O} \ldots 168$ 


\section{CURRICULUM VITAE}

Andre Ament werd geboren op 12 juli 1947 te Nederweert. Na de lagere school volgde hij de middelbare schoolopleiding aan het Bisschoppelijk College te Weert. Na het eindexamen gymnasium $B$ in 1966 studeerde hij atan de Katholieke Hogeschool Tilburg (tegenwoordig Katholieke Universiteit Brabant) waar hij in januari 1972 afstudeerde in de richting bedrijfseconometrie. Aansluitend was hij gedurende een viertal jaren werkzaam als wetenschappelijk medewerker aan het Instituut voor Gezondheidsvraagstukken, een instituut verbonden aan de Katholieke Hogeschool Tilburg.

Vanaf medio 1976 is hij verbonden als universitair docent aan de vakgroep Economie van de Gezondheidszorg aan de Rijksuniversiteit Limburg, waar hij werkzaamheden verrichtte voor de Medische Faculteit en later ook, in toenemende mate, voor de Faculteit der Gezondheidswetenschappen.

Binnen het vakgebied gezondheidseconomie is hij gespecialiseerd in de richting van de economische evaluatie. 